\title{
Assessment of Coal Geology, Resources, and Reserves in the Montana Powder River Basin
}

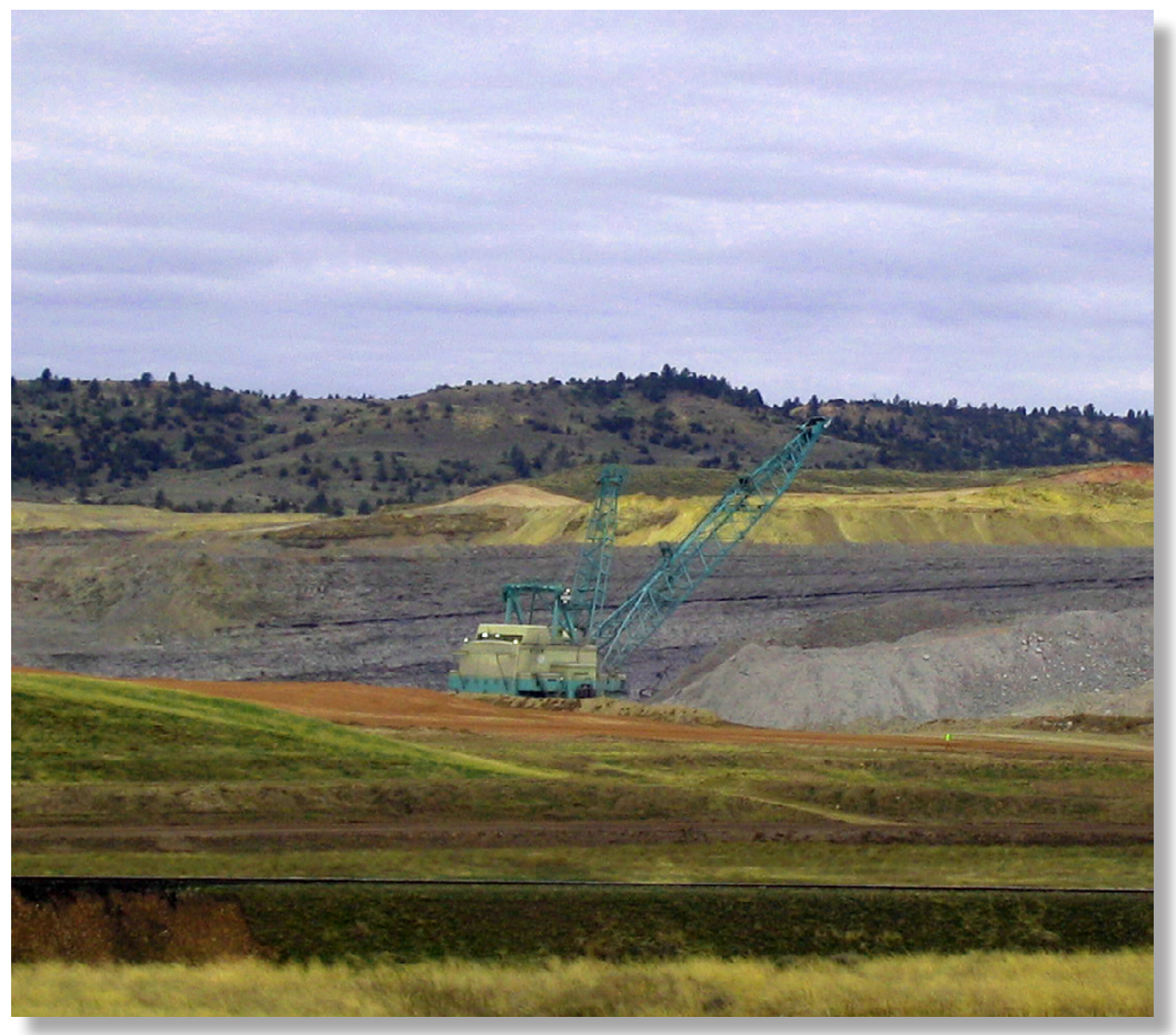

Open-File Report 2012-1113

U.S. Department of the Interior

U.S. Geological Survey 
Cover: Photograph taken near Decker, Montana, showing a dragline at a surface coal mine. Photograph by David C. Scott, U.S. Geological Survey, Denver, Colorado. 


\section{Assessment of Coal Geology, Resources, and Reserves in the Montana Powder River Basin}

By Jon E. Haacke, David C. Scott, Lee M. Osmonson, James A. Luppens, Paul E.

Pierce, and Jay A. Gunderson

Open-File Report 2012-1113

U.S. Department of the Interior

U.S. Geological Survey 


\section{U.S. Department of the Interior \\ KEN SALAZAR, Secretary}

\section{U.S. Geological Survey \\ Suzette M. Kimball, Acting Director}

U.S. Geological Survey, Reston, Virginia: 2013

For more information on the USGS - the Federal source for science about the Earth, its natural and living resources, natural hazards, and the environment, visit http://www.usgs.gov or call 1-888-ASK-USGS.

For an overview of USGS information products, including maps, imagery, and publications, visit http://www.usgs.gov/pubprod

To order this and other USGS information products, visit http://store.usgs.gov

Any use of trade, firm, or product names is for descriptive purposes only and does not imply endorsement by the U.S. Government.

Although this information product, for the most part, is in the public domain, it also may contain copyrighted materials as noted in the text. Permission to reproduce copyrighted items must be secured from the copyright owner.

Suggested citation:

Haacke, J.E., Scott, D.C., Osmonson, L.M., Luppens, J.A., Pierce, P.E, and Gunderson, J. A., 2013, Assessment of coal geology, resources, and reserves in the Montana Powder River Basin: U.S. Geological Survey Open-File Report 2012-1113, $133 \mathrm{p}$.

Quotations in this report contain errant and variant spellings that are reproduced as written. 


\section{Contents}

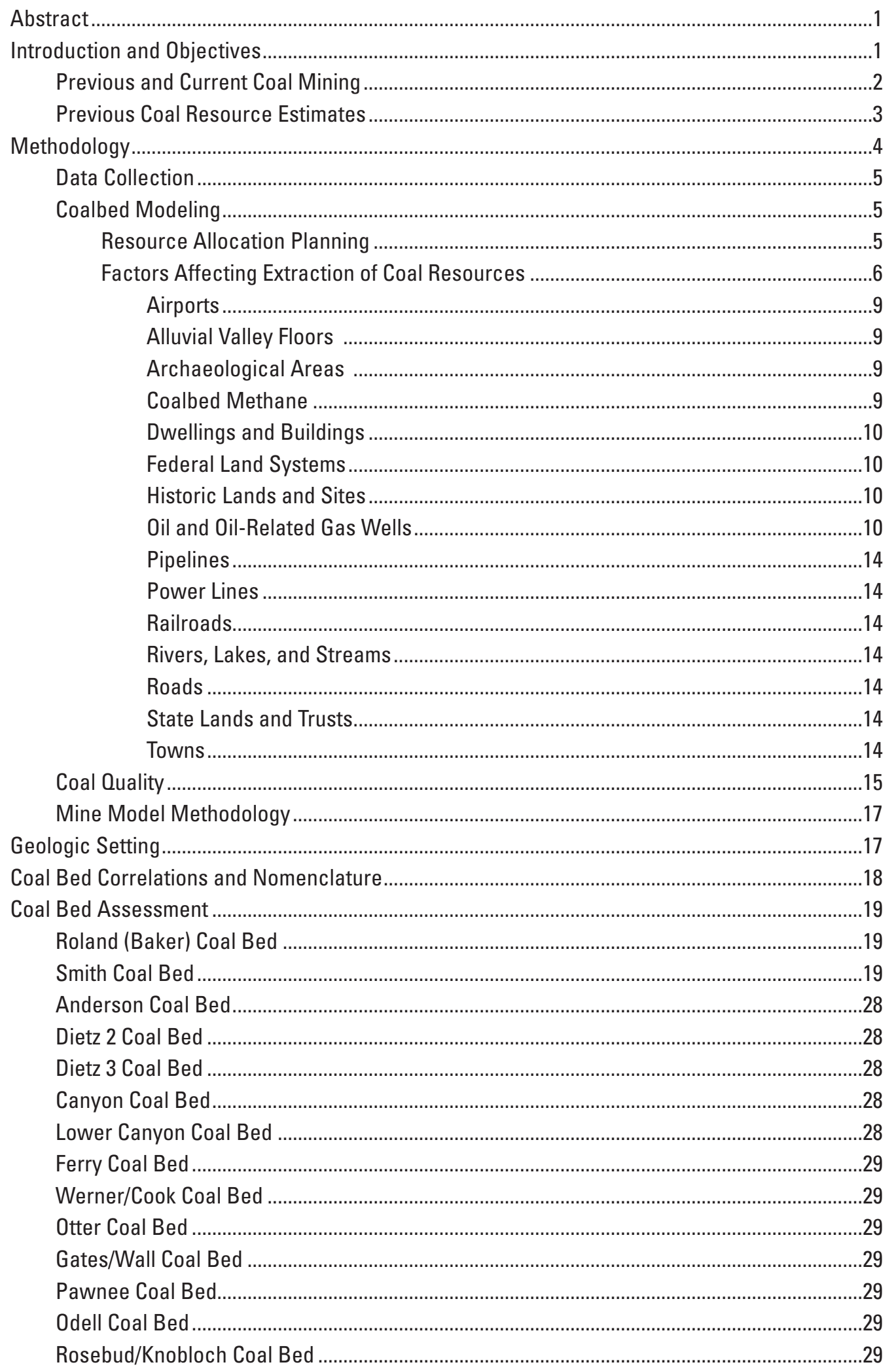




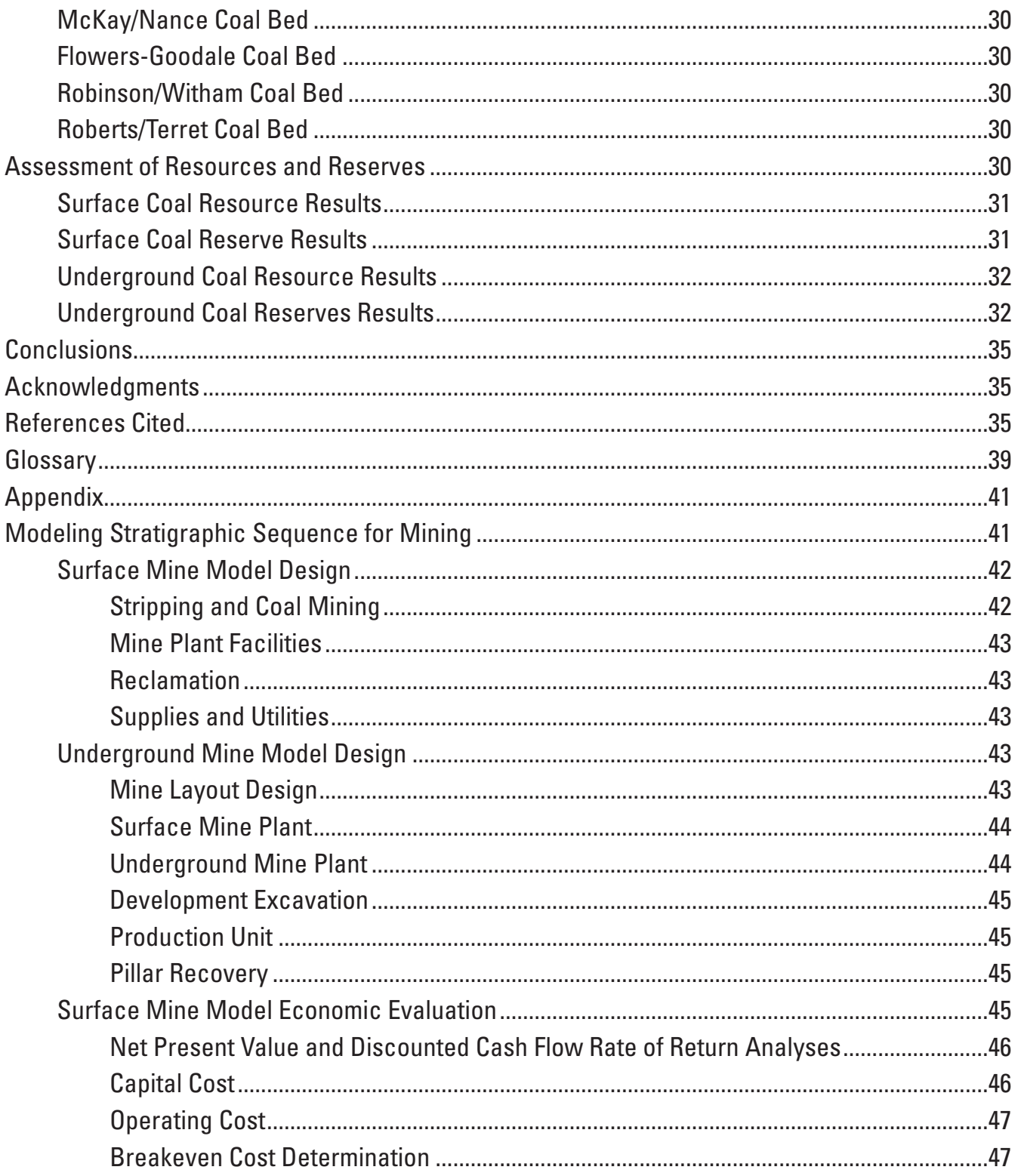

\section{Figures}

1. Location of the Montana Powder River Basin assessment area, Montana, Northern Wyoming Powder River Basin assessment area, Wyoming, Southwestern Powder River Basin assessment area, Wyoming, and Gillette coal field, Wyoming .

2. Map showing coal fields, mines, and lease areas in the Montana Powder River Basin assessment area

3. Flow chart showing generalized methodology used for coal resource and reserve evaluation...

4. Map showing drill-hole locations in the Montana Powder River Basin assessment area ....51

5. Illustration showing the effect of coal bed depth upon restricted resource due to mine-pit highwall setback requirements. 
6. Map showing land-use restrictions in the Montana Powder River Basin assessment area......

7. Map showing coal ownership in the Montana Powder River Basin assessment area ..........54

8. Areal extent for the Roland (Baker), Smith, Anderson, Dietz 2, and Dietz 3 coal beds where the stripping ratios are from 1:1 to $1: 10$, thicknesses are equal to at least $5.0 \mathrm{ft}$, and the overburden is less than or equal to $500 \mathrm{ft}$ thick in the Montana Powder River Basin assessment area

9. Areal extent for the Canyon coal bed where the stripping ratios are from 1:1 to 1:10, thicknesses are equal to at least $5.0 \mathrm{ft}$, and the overburden is less than or equal to $500 \mathrm{ft}$ thick in the Montana Powder River Basin assessment area

10. Areal extent for the Werner/Cook coal bed where the stripping ratios are from 1:1 to 1:10, Montana Powder River Basin assessment area

11. Areal extent for the Pawnee coal bed where the stripping ratios are from $1: 1$ to $1: 10$, thicknesses are equal to at least $5.0 \mathrm{ft}$, and the overburden is less than or equal to $500 \mathrm{ft}$ thick in the Montana Powder River Basin assessment area

12. Areal extent for the Rosebud/Knobloch coal bed where the stripping ratios are from $1: 1$ to $1: 10$, thicknesses are equal to at least $5.0 \mathrm{ft}$, and the overburden is less than or equal to $500 \mathrm{ft}$ thick in the Montana Powder River Basin assessment area

13. Areal extent for the Flowers-Goodale coal bed where the stripping ratios are from $1: 1$ to 1:10, thicknesses are equal to at least $5.0 \mathrm{ft}$, and the overburden is less than or equal to $500 \mathrm{ft}$ thick in the Montana Powder River Basin assessment area ......60

14. Map showing location of areas of low, moderate, and high coalbed methane potential in the Montana Powder River Basin assessment area

15. Map showing location of mines and area names for coal quality in the Montana Powder River Basin assessment area.

16. Map showing generalized geology of the Powder River Basin, Wyoming and Montana......63

17. Map showing location of mapped faults in the Montana Powder River Basin assessment area

18. Generalized stratigraphic column for the Powder River Basin, Wyoming and Montana ......65

19. Coal bed and coal zone names used in various publications in the Powder River Basin, Wyoming and Montana .66

20. Index map showing locations of cross sections from figures 21-27 in the Montana Powder River Basin assessment area

21. West-east cross section A-A' showing subsurface distribution of coal beds through the Spring Creek and Decker Mine areas in the Montana Powder River Basin assessment area.

22. West-east cross section B-B' showing subsurface distribution of coal beds north of the Spring Creek and Decker Mine areas in the Montana Powder River Basin assessment area.

23. West-east cross section $\mathrm{C}-\mathrm{C}^{\prime}$ showing subsurface distribution of coal beds through the Otter Creek Tracts (Arch Coal, Inc.) in the Montana Powder River Basin assessment area.

24. South-north cross section D-D' showing subsurface distribution of coal beds through the eastern part of the Montana Powder River Basin assessment area.

25. South-north cross section E-E' showing subsurface distribution of coal beds through the Spring Creek and Decker Mine areas in the Montana Powder River Basin assessment area.

26. South-north cross section F-F' showing subsurface distribution of coal beds through the central part of the Montana Powder River Basin assessment area 
27. Northwest-southeast cross section G-G' showing subsurface distribution of coal beds through the Montana Powder River Basin assessment area

28. Map showing location of clinker in the Montana Powder River Basin assessment area showing names used in the report.

29. Coal stratigraphy in the Montana Powder River Basin assessment area showing names used in this report

30. Isopachs showing extent of resources at least $2.5 \mathrm{ft}$ thick in the Roland (Baker) coal bed within the Montana Powder River Basin assessment area.

31. Maps of depth to the top of the Roland (Baker) coal bed within the Montana Powder River Basin assessment area

32. Maps of the coal resource reliability categories for the Roland (Baker) coal bed within the Montana Powder River Basin assessment area...

33. Isopachs showing extent of resources at least $2.5 \mathrm{ft}$ thick in the Smith coal bed within the Montana Powder River Basin assessment area ......

34. Map showing depth to the top of the Smith coal bed within the Montana Powder River Basin assessment area

35. Map showing coal resource reliability categories for the Smith coal bed within the Montana Powder River Basin assessment area.

36. Isopachs showing extent of resources at least $2.5 \mathrm{ft}$ thick in the Anderson coal bed within the Montana Powder River Basin assessment area

37. Map showing depth to the top of the Anderson coal bed within the Montana Powder River Basin assessment area

38. Map showing coal resource reliability categories for the Anderson coal bed within the Montana Powder River Basin assessment area

39. Isopachs showing extent of resources at least $2.5 \mathrm{ft}$ thick in the Dietz 2 coal bed within the Montana Powder River Basin assessment area.

40. Map showing depth to the top of the Dietz 2 coal bed within the Montana Powder River Basin assessment area

41. Map showing coal resource reliability categories for the Dietz 2 coal bed within the Montana Powder River Basin assessment area.

42. Isopachs showing extent of resources at least $2.5 \mathrm{ft}$ thick in the Dietz 3 coal bed within the Montana Powder River Basin assessment area

43. Map showing depth to the top of the Dietz 3 coal bed within the Montana Powder River Basin assessment area

44. Map showing coal resource reliability categories for the Dietz 3 coal bed within the Montana Powder River Basin assessment area

45. Isopachs showing extent of resources at least $2.5 \mathrm{ft}$ thick in the Canyon coal bed within the Montana Powder River Basin assessment area.

46. Map showing depth to the top of the Canyon coal bed within the Montana Powder River Basin assessment area

47. Map showing coal resource reliability categories for the Canyon coal bed within the Montana Powder River Basin assessment area.

48. Isopachs showing extent of resources at least $2.5 \mathrm{ft}$ thick in the Lower Canyon coal bed within the Montana Powder River Basin assessment area

49. Map showing depth to the top of the Lower Canyon coal bed within the Montana Powder River Basin assessment area

50. Map showing coal resource reliability categories for the Lower Canyon coal bed within the Montana Powder River Basin assessment area 
51. Isopachs showing extent of resources at least $2.5 \mathrm{ft}$ thick in the Ferry coal bed within the Montana Powder River Basin assessment area

52. Map showing depth to the top of the Ferry coal bed within the Montana Powder River Basin assessment area

53. Map showing coal resource reliability categories for the Ferry coal bed within the Montana Powder River Basin assessment area. 100

54. Isopachs showing extent of resources at least $2.5 \mathrm{ft}$ thick in the Werner/Cook coal bed within the Montana Powder River Basin assessment area . 101

55. Map showing depth to the top of the Werner/Cook coal bed within the Montana Powder River Basin assessment area

56. Map showing coal resource reliability categories for the Werner/Cook coal bed within the Montana Powder River Basin assessment area

57. Isopachs showing extent of resources at least $2.5 \mathrm{ft}$ thick in the 0 tter coal bed within the Montana Powder River Basin assessment area

58. Map showing depth to the top of the Otter coal bed within the Montana Powder River Basin assessment area ..... 105

59. Map showing coal resource reliability categories for the Otter coal bed within the Montana Powder River Basin assessment area 106

60. Isopachs showing extent of resources at least $2.5 \mathrm{ft}$ thick in the Gates/Wall coal bed within the Montana Powder River Basin assessment area

61. Map showing depth to the top of the Gates/Wall coal bed within the Montana Powder River Basin assessment area

62. Map showing coal resource reliability categories for the Gates/Wall coal bed within the Montana Powder River Basin assessment area

63. Isopachs showing extent of resources at least $2.5 \mathrm{ft}$ thick in the Pawnee coal bed within the Montana Powder River Basin assessment area

64. Map showing depth to the top of the Pawnee coal bed within the Montana Powder River Basin assessment area .....

65. Map showing coal resource reliability categories for the Pawnee coal bed within the Montana Powder River Basin assessment area

66. Isopachs showing extent of resources at least $2.5 \mathrm{ft}$ thick in the Odell coal bed within the Montana Powder River Basin assessment area

67. Map showing depth to the top of the Odell coal bed within the Montana Powder River Basin assessment area.

68. Map showing coal resource reliability categories for the Odell coal bed within the Montana Powder River Basin assessment area

69. Isopachs showing extent of resources at least $2.5 \mathrm{ft}$ thick in the Rosebud/Knobloch coal bed within the Montana Powder River Basin assessment area.

70. Map showing depth to the top of the Rosebud/Knobloch coal bed within the Montana Powder River Basin assessment area

71. Map showing coal resource reliability categories for the Rosebud/Knobloch coal bed within the Montana Powder River Basin assessment area

72. Isopachs showing extent of resources at least $2.5 \mathrm{ft}$ thick in the McKay/Nance coal bed within the Montana Powder River Basin assessment area

73. Map showing depth to the top of the McKay/Nance coal bed within the Montana Powder River Basin assessment area

74. Map showing coal resource reliability categories for the McKay/Nance coal bed within the Montana Powder River Basin assessment area 
75. Isopachs showing extent of resources at least $2.5 \mathrm{ft}$ thick in the Flowers-Goodale coal bed within the Montana Powder River Basin assessment area.

76. Map showing depth to the top of the Flowers-Goodale coal bed within the Montana Powder River Basin assessment area

77. Map showing coal resource reliability categories for the Flowers-Goodale coal bed within the Montana Powder River Basin assessment area

78. Isopachs showing extent of resources at least $2.5 \mathrm{ft}$ thick in the Robinson/Witham coal bed within the Montana Powder River Basin assessment area.

79. Map showing depth to the top of the Robinson/Witham coal bed within the Montana Powder River Basin assessment area.

80. Map showing coal resource reliability categories for the Robinson/Witham coal bed within the Montana Powder River Basin assessment area

81. Isopachs showing extent of resources at least to $2.5 \mathrm{ft}$ thick in the Roberts/Terret coal bed within the Montana Powder River Basin assessment area

82. Map showing depth to the top of the Roberts/Terret coal bed within the Montana Powder River Basin assessment area.

83. Map showing coal resource reliability categories for the Roberts/Terret coal bed within the Montana Powder River Basin assessment area

84. Pie chart of 18 beds showing amount and percent of total original coal resources (215 BST) by coal bed in the Montana Powder River Basin assessment area

85. Cost curve showing estimated recoverable resources vs. sales price per ton of coal.......132

86. Bar graph showing resources in different resource categories for the ten coal beds included in the reserve evaluation of the Montana Powder River Basin assessment area, reported in billions of short tons.

87. Bar graph showing resources in different resource categories for the ten coal beds included in the reserve evaluation of the Montana Powder River Basin assessment area, reported in percentages 


\section{Tables}

1. Coal production from the Montana Powder River Basin assessment area .................................3

2. Available and recoverable resources of 10 beds at least $5.0 \mathrm{ft}$ thick and less than or equal to a 10:1 strip ratio in the Montana Powder River Basin assessment area ..............7

3. Available and recoverable resources for 10 coal beds at least $5.0 \mathrm{ft}$ thick, reported by bed, for restrictions, recovery rates, mining losses, and recoverable resources for the Montana Powder River Basin assessment area.

4. Coal resources and restrictions for 18 beds greater than or equal to 2.5 feet thick, reported in millions of short tons by coal ownership categories for the Montana Powder River Basin assessment area

5. Available as-received coal-quality data for mines and mine leases in the Montana Powder River Basin assessment area .

6. Available as-received coal-quality data for coal fields and areas in the Montana Powder River Basin assessment area

7. Comparison of proximate analysis of coals from mines in the Wyoming and Montana portions of the Montana Powder River Basin assessment area.

8. Coal resources and restrictions for 18 beds greater than or equal to 2.5 feet thick, reported in millions of short tons by coal overburden depth for the Montana Powder River Basin assessment area

9. Coal resources and restrictions for 18 beds greater than or equal to 2.5 feet thick, reported in millions of short tons by reliability category for the Montana Powder River Basin assessment area

10. Life-of-mine costs by strip ratio in the Montana Powder River Basin assessment area ......32

11. Underground resources in beds at least 10 feet thick and a strip ratio of $>10: 1$, in the Montana Powder River Basin assessment area

12. Costs by underground mining case for the Montana Powder River Basin assessment area based on a 20-year project life at an annual production rate of 6 million short tons per year...

13. Regional mining model stratigraphic sequence used in the economic evaluation of the Montana Powder River Basin assessment area.

14. Underground excavation dimensions in the longwall mining model for a $10-\mathrm{ft}$ mining height 


\section{Abbreviations Used in This Report}

$\begin{array}{ll}\text { Btu/lb } & \text { British thermal unit per pound } \\ \mathrm{ft} & \text { feet } \\ \mathrm{ft}^{2} & \text { square feet } \\ \mathrm{hr} & \text { hour } \\ \text { in } & \text { inch } \\ \mathrm{mi} & \text { mile } \\ \mathrm{mi}^{2} & \text { square mile } \\ \text { yd } & \text { cubic yards } \\ \text { yr } & \text { year } \\ \text { BST } & \text { billion short tons } \\ \text { CARS } & \text { coal availability and resource studies } \\ \text { CBM } & \text { coalbed methane } \\ \text { GIS } & \text { geographic information system } \\ \text { MBMG } & \text { Montana Bureau of Mines and Geology } \\ \text { MST } & \text { million short tons } \\ \text { MST/yr } & \text { million short tons per year } \\ \text { MTPRB } & \text { Montana Powder River Basin assessment area } \\ \text { NWPRB } & \text { Northern Wyoming Powder River Basin assessment area } \\ \text { PRB } & \text { Powder River Basin } \\ \text { ST } & \text { short ton } \\ \text { SWPRB } & \text { Southwestern Powder River Basin assessment area } \\ \text { USBLM } & \text { U.S. Bureau of Land Management } \\ \text { USGS } & \text { U.S. Geological Survey } \\ \text { UTM } & \text { Universal Transverse Mercator } \\ & \end{array}$




\section{Conversion Factors}

\begin{tabular}{lcl}
\hline \multicolumn{1}{c}{ Multiply } & By & \multicolumn{1}{c}{ To obtain } \\
\hline foot (ft) & Length & meter $(\mathrm{m})$ \\
mile (mi) & 0.3048 & kilometer $(\mathrm{km})$ \\
square mile $\left(\mathrm{mi}^{2}\right)$ & 1.609 & square kilometer $\left(\mathrm{km}^{2}\right)$ \\
square feet $\left(\mathrm{ft}^{2}\right)$ & 2.590 & square meters $\left(\mathrm{m}^{2}\right)$ \\
\hline & 0.0929 & \\
\hline pounds $(\mathrm{lbs})$ & Density & kilograms $(\mathrm{kg})$ \\
short tons $(2,000$ lbs) & 0.4536 & metric tons $(2,204.6 \mathrm{lbs})$ \\
millions of short tons (MST) & 0.90718474 & short tons \\
billions of short tons (BST) & $1,000,000$ & short tons \\
trillions of short tons (TST) & $1,000,000,000,000,000$ & short tons \\
\hline & Area & \\
\hline acre-ft & 1,770 & short tons of subbituminous coal \\
\hline
\end{tabular}





\title{
Assessment of Coal Geology, Resources, and Reserves in the Montana Powder River Basin
}

\author{
By Jon E. Haacke, ${ }^{1}$ David C. Scott, ${ }^{1}$ Lee M. Osmonson, ${ }^{1}$ James A. Luppens, ${ }^{2}$ Paul E. Pierce, ${ }^{2}$ and \\ Jay A. Gunderson ${ }^{3}$
}

\section{Abstract}

The purpose of this report is to summarize geology, coal resources, and coal reserves in the Montana Powder River Basin (MTPRB) assessment area in southeastern Montana. This report represents the fourth assessment area within the Powder River Basin to be evaluated in the continuing U.S. Geological Survey regional coal assessment program.

There are four active coal mines in the MTPRB assessment area: the Spring Creek and Decker Mines, both near Decker; the Rosebud Mine, near Colstrip; and the Absaloka Mine, west of Colstrip. During 2011, coal production from these four mines totaled approximately 36 million short tons (MST). A fifth mine, the Big Sky, had significant production from 1969-2003; however, it is no longer in production and has since been reclaimed. Total coal production from all five mines in the MTPRB assessment area from 1968 to 2011 was approximately 1.4 billion short tons (BST). The Rosebud/ Knobloch coal bed near Colstrip and the Anderson, Dietz 2, and Dietz 3 coal beds near Decker contain the largest deposits of surface minable, low-sulfur, subbituminous coal currently being mined in the assessment area.

A total of 26 coal beds were identified during this assessment, 18 of which were modeled and evaluated to determine in-place coal resources. The total original coal resource in the MTPRB assessment area for the 18 coal beds assessed was calculated to be 215 BST. Available coal resources, which are part of the original coal resource remaining after subtracting restrictions and areas of burned coal, are about 162 BST. Restrictions included railroads, Federal interstate highways, urban areas, alluvial valley floors, state parks, national forests, and mined-out areas.

It was determined that 10 of the 18 coal beds had sufficient areal extent and thickness to be evaluated for recoverable surface resources ([Roland (Baker), Smith, Anderson, Dietz 2, Dietz 3, Canyon, Werner/Cook, Pawnee, Rosebud/Knobloch, and Flowers-Goodale]). These 10 coal beds total about $151 \mathrm{BST}$ of the $162 \mathrm{BST}$ of available resource; however, after applying a strip ratio of 10:1 or less, only 39 BST remains of the 151 BST. After mining and processing losses are subtracted from the $39 \mathrm{BST}, 35 \mathrm{BST}$ of coal were considered as a recoverable resource. Coal reserves (economically recoverable coal) are the portion of the recoverable coal resource that can be mined, processed, and marketed at a profit at the time of the economic evaluation. The surface coal reserve estimate for the 10 coal beds evaluated for the Montana Powder River assessment area is 13 BST.

It was also determined that about $42 \mathrm{BST}$ of underground coal resource exists in the MTPRB assessment area; about 34 BST ( 80 percent) are within $500-1,000 \mathrm{ft}$ of the land surface and another 8 BST are 1,000-2,000 ft beneath the land surface.

\section{Introduction and Objectives}

Coal resource and reserve estimates are essential for use in making local, state, and federal energy and land-use policy decisions for the foreseeable future. These estimates can also aid planners in determining the possible socio-economic effects on the region as coal resources are developed and approach depletion (Luppens and others, 2008).

The U.S. Geological Survey (USGS) completed the first digital National Coal Resource Assessment of in-place coal resources in 2009 (Pierce and Dennen, 2009); however, the estimates do not, by themselves, provide all the information needed for resource planning. Calculations of that portion of the in-place coal resources that are economically recoverable are equally important (Luppens and others, 2008).

${ }^{1}$ U.S. Geological Survey, Denver, Colorado 80225.

${ }^{2}$ U.S. Geological Survey, Reston, Virginia 20192.

${ }^{3}$ Montana Bureau of Mines and Geology, Billings, Montana 59101. 
Confusion concerning the use of the terms coal resources ${ }^{4}$ and coal reserves is common, and the two terms have been used interchangeably. However, there is a major difference: (1) coal resources include those in-place tonnage estimates determined by summing the volumes for identified resources and hypothetical resources using coal zones of a minimum thickness and within certain depth limits (commonly 0-2,000 $\mathrm{ft}$ deep) (Pierce and Dennen, 2009), whereas (2) coal reserves constitute a subset of the coal resources that is considered economically producible at the time of classification (Pierce and Dennen, 2009). Luppens and others (2009) discussed coal resources and coal reserves and summarized how coal availability and resource studies (CARS) are used to determine estimates of economically recoverable coal resources.

Previous estimates of coal resources and reserves have typically used average mining percentages to obtain volume estimates of recoverable coal (see references in "Previous Coal Resource Estimates" section). Those estimates are general and do not take into consideration the volume of coal that cannot be mined because of environmental concerns, geological constraints, coal loss because of mining and preparation technology, or economic constraints. Published studies by the USGS have indicated that application of site-specific restrictions to estimates of available coal resources significantly reduces the amount of coal that is considered recoverable (for example, Ellis and others, 2002).

At the time of publication of this report, the USGS assessment project is the Powder River Basin (PRB), located in southeastern Montana and northeastern Wyoming (fig. 1).

The PRB project was divided into four assessment areas to keep databases and modeled areas to a more manageable size and permit more timely publication of assessment results. Luppens and others (2008) reported on the first assessment area and summarized coal resources and reserves for the Gillette coal field (fig. 1), Scott and others (2010) summarized the second assessment area that contained coal resource and reserve estimates for the Northern Wyoming Powder River Basin assessment area (NWPRB assessment area), and Osmonson and others (2011) summarized coal resources in the Southwestern Powder River Basin assessment area (SWPRB assessment area) (fig. 1).

This report summarizes the fourth assessment area within the PRB, which covers an area of approximately $7,765 \mathrm{mi}^{2}$ in the Montana portion of the PRB in parts of Big Horn, Custer, Powder River, Rosebud, and Treasure Counties, Montana (fig. 1). The assessment area extends south from Miles City, Montana to the northern state boundary of Wyoming and from the eastern boundaries of the Crow and Northern Cheyenne Indian Reservations easterly to a few miles east of Broadus, Montana. The assessment area will be referred to in this report as the Montana Powder River Basin assessment area (MTPRB assessment area).

\footnotetext{
${ }^{4}$ Technical terms used in this report requiring additional explanation are italicized when used for the first time and their definitions are given in the Glossary section at the end of the report.
}

Coal availability and recoverability studies in the United States have previously relied on reinterpretation of existing data; however, because of the recent development of coalbed methane in the Decker Mine area, new data from drill holes are now available. The interpretation of these new data provides a view of the coal resources and reserves in the assessment area.

The primary objectives of this assessment are as follows:

1. Complete the fourth coal resource and reserve assessment in the PRB.

2. Update the current stratigraphic database with information obtained from recently completed coalbed methane well and oil and gas well data, thereby improving geological modeling in the assessment area.

3. Develop a more comprehensive in-place coal resource computer model with the geological assurance to support regional reserve estimates.

4. Complete an economic mining evaluation that was customized to the environmental and technological restrictions in the MTPRB assessment area and derive a regional estimate of coal resources and reserves.

\section{Previous and Current Coal Mining}

On July 28, 1806, Captain William Clark of the Corps of Discovery documented coal beds as he floated down the Yellowstone River along the northern margin of the Powder River Basin:

\section{"...in the evening I passd. Straters of Coal in the banks on either Side. those on the Stard. Bluffs was about 30 feet above the water and in 2 vanes from 4 to 8 feet thick, in a horozontal position. the Coal Contained in the Lard Bluffs is in Several vaines of different hights and thickness. this Coal or Carbon- ated wood is like that of the Missouri of an inferior quality." (Moulton, 2001).}

Less than a year later, Manuel Lisa built a trading post at the confluence of the Bighorn and Yellowstone Rivers and used lignite coal from nearby outcrops to heat buildings during the winter months (Morgan, 1966). Coal within the MTPRB assessment area was not commercially mined until 1923 when the first modern-day strip mine in the western United States was opened at Colstrip, Montana. The coal was mined by Northern Pacific Railroad Company and used to fuel steam locomotives. In the mid-1940s, coal production from the Rosebud Mine at Colstrip reached peak production of just more than 4 million short tons (MST) per year. However, by 1957 the mine was closed after a decade-long decrease in coal demand as steam locomotives were gradually replaced by diesel locomotives (Morgan, 1966). In 1968, Montana Power Company 
acquired the Rosebud Mine and formed a subsidiary, Western Energy Company, to manage and develop the Colstrip properties (U.S. Office of Surface Mining, 1983). Total coal production from 1923-1968 for the MTPRB assessment area was less than 45 MST (Department of Labor and Industry, Safety and Health Bureau, State of Montana, written commun., 2011).

In 1970, the Environmental Protection Agency Clean Air Act created a new and significant demand for low-sulfur coal, and consequently, the Powder River Basin emerged as one of the nation's primary coal-producing regions. By the mid-1970s, strip mines within the MTPRB assessment area had production totaling more than 20 MST per year, and accounted for 98 percent of all Montana coal production (Jay Gunderson, Montana Bureau of Mines and Geology, written commun., 2011).

The Ashland, Birney-Broadus, Coalwood, Forsyth, Miles City, Mizpah, Moorhead, northward extension of the Sheridan coal field, and Rosebud coal fields are all within the MTPRB assessment area (fig. 2) (Averitt, 1966; McLellan and others, 1990). There are four active coal mines in the MTPRB assessment area: the Spring Creek and Decker (West, East, and North) Mines, near Decker; the Rosebud Mine, near Colstrip; and the Absaloka Mine, west of Colstrip (fig. 2). Coal production from these four mines in 2011 totaled approximately 36 MST (table 1) (Department of Labor and Industry, Safety and Health Bureau, State of Montana, written commun., 2011). The Big Sky Mine also had significant production, but ended mining operations in 2003 (table 1, fig. 2). Total production from all 5 mines from 1968-2010 was about 1.4 billion short tons (BST) (table 1)
(Department of Labor and Industry, Safety and Health Bureau, State of Montana, written commun., 2011).

Western Energy Company began mining coal at the Rosebud Mine near Colstrip in 1968. Early production was shipped out of state by railroad to coal-fired electrical generating plants. Beginning in 1975, onsite electrical generation commenced at Colstrip. Since 1985, coal production from the mine has averaged about 12 MST per year. Peabody Coal began operations at the Big Sky Mine just south of Colstrip in 1969 and closed operations in 2003. Coal production from the mine averaged about 2 MST per year. The Absaloka Mine, located 10-12 mi west of the Rosebud Mine, began development in 1974 and production in 1975. The mine, owned and operated by Westmoreland Resources, Inc., produced an average of about 5-7 MST per year. The Spring Creek Mine, located near Decker, opened in 1979 and had production of about 2 MST in 1983. The mine is owned and operated by Cloud Peak Energy Resources LLC. The Decker East, West, and North Mines, located near Decker, began operating in 1970 after development of a 19-mi-long railroad spur from Sheridan, Wyoming. The mines are owned by Decker Coal Company and operated by Kiewit Mining Group, Inc.

In 2010, Arch Coal Inc. acquired the right to mine 572 MST of state-owned coal in Otter Creek, south of Ashland (fig. 2); Arch Coal Inc. already controlled 731 MST of privately owned coal in the Otter Creek area (Mike Dennison, The Billings Gazette, March 16, 2010; accessed at: http// billingsgazette.com/news/state-and-regional/Montana/article dce41c8a-3163-11df-b2).

Table 1. Coal production from the Montana Powder River Basin assessment area.

[Department of Labor and Industry Safety and Health Bureau, State of Montana, P.O. Box 1728, Helena, MT, 59624 (Jay Gunderson, personal communication, January, 2011)]

\begin{tabular}{llcc}
\hline \multicolumn{1}{c}{$\begin{array}{c}\text { Mine name, } \\
\text { years of production }\end{array}$} & \multicolumn{1}{c}{ Coal bed name } & $\begin{array}{c}\text { Coal production } \\
\text { in 2011 } \\
\text { (millions of tons) }\end{array}$ & $\begin{array}{c}\text { Total coal } \\
\text { production } \\
\text { (millions of tons) }\end{array}$ \\
\hline Absaloka (1975-2011) & Rosebud & 5.1 & 178.9 \\
Big Sky (1969-2003) & Rosebud & --- & 97.9 \\
Decker (1970-2011) & Anderson, Dietz 1, Dietz 2 & 3.1 & 362.3 \\
Rosebud (1968-2011) & Rosebud & 8.8 & 440.1 \\
Spring Creek (1983-2011) & Anderson, Dietz 1, Dietz 2 & 19.1 & 288.9 \\
Total & & $\mathbf{3 6 . 1}$ & $\mathbf{1 , 3 6 8 . 1}$ \\
\hline
\end{tabular}

\section{Previous Coal Resource Estimates}

Previous studies in the MTPRB included different coal beds, coal zones, and boundaries, and had different purposes for which resources and reserves were calculated. Differences in criteria, such as variations in coal thickness, overburden depth, and areal extent of coal beds were used for calculations of coal tonnages. Nevertheless, the previous studies form the foundation for most of the coal resource compilations that followed. The following is a chronological list of some of the more significant resource and reserve estimates for the MTPRB.

1. Combo and others (1949) published a detailed report summarizing Montana coal resources by county, rank, reliability category, and thickness. Their estimate for the total coal resources in Montana was 222 
BST, 126 of which are within the MTPRB assessment area. This included reliability categories of measured, indicated, inferred, and hypothetical based on distance from the drill hole or outcrop and depths up to $2,000 \mathrm{ft}$. The measured and indicated coal reserves for the assessment area were estimated to be $47 \mathrm{BST}$ and included beds $2.5 \mathrm{ft}$ thick and greater.

2. The USGS estimated original coal resources in the MTPRB assessment area for five counties (Big Horn, Custer, Powder River, Rosebud, and Treasure) at $127 \mathrm{BST}$ in beds that were $2.5 \mathrm{ft}$ or more in thickness (Averitt, 1966).

3. In 1968, Groff estimated 5.3 BST of strippable reserves in the MTPRB (Groff, 1968).

4. Ayler and others (1969) estimated strippable coal reserves for the MTPRB for several coal fields. Strippable coal reserves in the northward extension of the Sheridan coal field (Decker and Spring Creek Mine areas) were estimated at 2,265 MST for seven coal beds with a maximum overburden of $120 \mathrm{ft}$ (fig. 2). Strippable coal reserves for the Birney-Broadus coal field were estimated for 3 coal beds at 996 MST with a maximum overburden depth ranging between 50 and $200 \mathrm{ft}$ (fig. 2). Strippable coal reserves for the Ashland and Coalwood coal fields combined were estimated to be 3,457 MST for 7 coal beds with maximum overburden depth ranging between 120 and $200 \mathrm{ft}$ (fig. 2). Strippable coal reserves for the Forsyth coal field (Rosebud Mine area) were estimated to be 711 MST for three coal beds with a maximum overburden thickness between 110 and $130 \mathrm{ft}$ (fig. 2).

5. Matson (1971) estimated strippable subbituminous coal reserves in the Moorhead coal field for three coal beds beneath less than $150 \mathrm{ft}$ of overburden at 1,979 MST (fig. 2).

6. Matson and Blumer (1973) estimated strippable coal reserves for much of the area in the MTPRB that included parts of Big Horn, Custer, Powder River, and Rosebud Counties (fig. 2). The strippable coal resources in the deposits discussed in that report totaled approximately $32 \mathrm{BST}$. The coal beds are fairly evenly distributed throughout the Tongue River Member of the Fort Union Formation.

7. Matson and White (1975) published a report that summarized underground coal reserves by first assigning reliability categories to those resources reported as unclassified as to thickness by Combo and others (1949), then subtracting published strippable coal reserve numbers. Matson and White (1975) estimated $60 \mathrm{BST}$ of underground coal reserves in Big Horn, Powder River, and Rosebud Counties.
8. Roberts and others (1999a) estimated coal resources for a $395-\mathrm{mi}^{2}$ area defined as the Colstrip coal field, which included parts of the Forsyth and Ashland coal fields (fig. 2). Resources were estimated based on reliability categories of measured, indicated, inferred, and hypothetical categories and totaled more than 12.6 BST.

9. Roberts and others (1999b) estimated coal resources for a $1,100-\mathrm{mi}^{2}$ area defined as the Decker coal field that included parts of the northward extension of the Sheridan coal field, the Moorhead coal field, and the Birney-Broadus coal field (fig. 2). Resources were estimated based on measured, indicated, inferred, and hypothetical categories and totaled 45 BST.

10. Roberts and others (1999c) also estimated coal resources for a $520-\mathrm{mi}^{2}$ area defined as the Ashland coal field that includes parts of the northward extension of the Sheridan coal field, the Moorhead coal field, and the Birney-Broadus coal field (fig. 2). Resources were estimated based on measured, indicated, inferred, and hypothetical categories and totaled 6 BST.

11. Coal availability assessments for several 7.5 minute quadrangles in the MTPRB were performed in the early 2000s (Wilde, 2000; Wilde and Myers, 2003; and Wilde and Sandau, 2004, 2005).

As documented in these various estimates, resource and reserve estimates change as more data become available. These new estimates prove the usefulness of periodically recalculating coal resources and reserves. Because of the availability of new data, the coal resources and economic coal recoverability calculations presented in this report are a significant refinement of previous coal resource and reserve studies in the MTPRB assessment area.

\section{Methodology}

The methodology for calculating coal resources and reserves in the MTPRB assessment area is described in three phases shown on the flow chart in figure 3 . This methodology is the same as was used for the previous three PRB assessments (Gillette coalfield by Luppens and others, 2008; NWPRB assessment area by Scott and others, 2010; and the SWPRB assessment area by Osmonson and others, 2011). The first phase involved data collection and editing, as a result of the acquisition of recently generated geologic information. The second phase consisted of modeling coal beds, creating models of restrictions to mining, and calculating tonnages for original, mined out, restricted, and available resources. The third phase involved completing a mining economics evaluation to determine coal economically recoverable resources (reserves). 


\section{Data Collection}

There are 3,137 publically available drill-hole logs in the MTRPB assessment area, of which 2,974 were used to construct the database used in this assessment (fig. 4): 520 oil and gas wells, 290 coalbed methane wells, and 2,164 coal exploration drill holes. Data selected for entry were supplied by the Montana Bureau of Mines and Geology, the USGS National Coal Resource Database System (NCRDS), and MJ Systems (2009). USGS personnel entered data from the entire 2,974 drill-hole logs into the StratiFact ${ }^{\circledR}$ database program (GRG Corporation, 1998). Data for all public drill holes in the Powder River Basin were published by Haacke and Scott (2012).

Gamma-ray logs were available for most of the wells and constituted the basis for most of the lithologic interpretation. Traditionally, oil and gas wells were logged primarily for detail in deep formations, and the upper (coal-bearing) intervals were either not logged or minimally gamma logged through the surface casing. Log data in older wells generally consisted of spontaneous potential, resistivity, and conductivity logs. The most reliable log suite for distinguishing coal beds consisted of natural gamma, gamma-gamma density, and resistivity traces; however, many coalbed methane wells were logged with gamma-ray only, either in open hole or through steel drill pipe or casing. Additionally, some of the coalbed methane wells were logged only to the top of the target coal.

Detailed non-coal lithology types were not critical to the results of this evaluation. As a result, all lithologies were coded as either coal or rock. Parting intercepts within coal beds and interburden between coal beds were also coded as rock. Intervals with no geophysical log were entered as "No Log".

\section{Coalbed Modeling}

The first step of phase two of the assessment (fig. 3) was the creation of digital coal bed models. Following coal bed correlations, preliminary coal isopach thickness maps were created using the single- bed modeling program Surfer $^{\circledR}$ (Golden Software, 2002) to decide which coal beds would be included in the geologic coal resource model. The basic criterion for inclusion was a minimum areal continuity of two or more townships $\left(721 \mathrm{mi}^{2}\right)$. Twenty-six coal beds were identified in this assessment; however, based on thickness and areal extent, only eighteen were selected for digital modeling to calculate resources. The integrated multi-bed modeling program PC/Cores ${ }^{\circledR}$ (Mentor Consultants, 2005) was used to produce gridded coal bed models. This modeling program was designed for coal and mineral evaluations and is effective for coal bed modeling because of the capability to grid multiple beds at one time. This program allows for a considerable reduction in time when compared with other programs that grid only one parameter at a time. Time required to produce grids using a program that generates grids one parameter at a time can be large, considering that for each coal bed, grids must be made for coal thickness, parting thickness, coal height (coal plus parting), and roof and floor structures. Grids must then be calculated for the overburden and interburden thicknesses for each seam. The roof grid for each coal bed must be individually subtracted from the surface grid or the floor grid for the next stratigraphically higher coal bed.

The coal bed models were gridded at a cell size of $150 \mathrm{~m}$ $(\sim 500 \mathrm{ft})$. For this assessment, meters were used when discussing modeling, whereas English units were used for thicknesses and depths. To verify coal bed correlations and coal bed areal distributions, preliminary roof and floor contour maps for each modeled bed were generated to check for anomalies. The PC/ Cores program was used to help identify anomalies by comparing collar elevations to the digital elevation model of the Earth's surface.

Subsequent to completion of editing, final geologic models were created and all grids necessary for determination of in-place coal resource volumes were generated. A copy of the in-place coal resource model was modified to generate the grids necessary for coal reserve evaluation. The basic assumption used to qualify coal beds for potential coal reserve evaluation was a thickness of at least $2.5 \mathrm{ft}$. A final set of grids from both the coal resources and reserves models (thickness, parting thickness, and roof and floor structures) for each coal bed was converted in PC/Cores to a generic ASCII grid format. These ASCII grids were then exported to the program $\mathrm{ArcView}^{\circledR}$ [Environmental Systems Research International, 2001] to begin the last step in phase two of the assessment, which was the modeling of the restrictions to mining.

\section{Resource Allocation Planning}

The objective in resource planning is to determine the amount of available coal resources. This process is accomplished by first subtracting the amount of previously mined coal from the calculated amount of the original resources; the result is remaining resources. Subtracting the amount of land use and technical restrictions from the amount of remaining resources yields available resources. The following discussion details the methodology used in determining available resources.

Digital modeling for the evaluated coal beds was done using PC/Cores (Mentor Consultants, 2005); files were then imported into a geographic information system (GIS). The GIS system was used to allocate coal resources by first subtracting amounts of various restrictions to mining (previously mined coal, towns, national forests, alluvial valley floors, and so on) in order to calculate the amount of available coal.

$\mathrm{ArcView}^{\circledR}$ and the ArcView Spatial Analyst ${ }^{\circledR}$ extension (Environmental Systems Research Institute, Inc., 2000, 2001) were used to perform the various GIS analyses and ultimately calculate the amount of coal resources. In addition, ArcGIS ${ }^{\circledR}$ (Environmental Systems Research Institute, Inc., 2006) was used to project digital coverages, shapefiles, or grids to the assessment area's base-map projection. The geographic referencing base of the digital data used for the GIS analysis was 
the Universal Transverse Mercator (UTM) map projection, using the following parameters: map units $=$ meters; zone $=13$; datum $=$ NAD27; and spheroid $=$ Clarke 1866 .

USGS coal resource assessments do not have a standard grid-cell size used for all GIS analyses. For this GIS assessment, a grid-cell size of $30 \mathrm{~m}(\sim 100 \mathrm{ft})$ was chosen. Consequently, all grids used within the GIS analysis were either originally created with a grid-cell size of $30 \mathrm{~m}$ or resampled to $30 \mathrm{~m}$ from another cell size. In the case of the digital coalmodel grids, the cell size was resampled from $150 \mathrm{~m}$ to $30 \mathrm{~m}$.

The first task in the GIS process involved the creation of ArcView $^{\circledR}$ (Environmental Systems Research Institute, Inc., 2000) grids from ASCII files of the coal, parting, and overburden isopach grids, that were created by the digital coal models. These $\mathrm{ArcView}^{\circledR}$ grids were then used to create a total thickness (coal plus parting) grid, and areal-extent grid for each coal bed to be evaluated. The next step involved creating a group of grids that categorized the MTPRB assessment area, with each grid representing one specific theme. These grid themes consisted of mined-out areas, burned-coal areas, land-use restrictions, technical restrictions, overburden-to-coal bed ratios, counties, coal ownership, stripping ratios, resource reliability categories, and coal bed depth. The grid theme for previously mined coal was derived from digital information obtained from the Montana Department of Environmental Quality. The grid theme for burned-coal areas was developed from digital surface clinker information obtained from the Montana Bureau of Mines and Geology Geographic Information Systems Laboratory (http://www.mbmg.mtech.edu/gis/ gis-datalinks.asp). The grid theme for coal ownership was obtained from USGS digital information (http://pubs.usgs.gov/ of/1998/ofr-98-0102). The grid themes for land-use restrictions and counties were derived from digital information obtained from the Natural Resource Information System GIS Data List of the Montana government (2011) (the remaining grid themes were developed internally within the USGS).

The grid of environmental restrictions includes buffer zones that surround each restricted area. The location and width of these buffers are typically mandated by State or Federal regulations. Each restriction buffer measures hundreds of feet in width at the surface, as discussed in the Factors Affecting Extraction of Coal Resources section of this report.

One of the improvements in the assessment methodology was revising the technique for defining surface restrictions at depth. Previous economic assessments used a standard approach when applying regulatory surface buffers (such as a 300-ft buffer around an inhabited house) below the surface. The surface buffers were simply projected vertically downward through the coal beds to be evaluated. However, a restricted area actually widens with depth when surface-mining operations are considered, because of the additional setback distance required to maintain a safe mining-pit highwall angle. Consequently, the area that is affected by a restriction becomes larger, the deeper a coal bed lies beneath the surface. For example, a circular restriction having a diameter of 600 $\mathrm{ft}$ at the surface encompasses an area of about $282,600 \mathrm{ft}^{2}$, or approximately 6.5 acres. However, at a depth of $200 \mathrm{ft}$ this same restriction has a diameter of $858 \mathrm{ft}$ and encompasses an area of about $577,900 \mathrm{ft}^{2}$, or approximately 13 acres. At a depth of $500 \mathrm{ft}$ the same restriction has a diameter of 2,144 ft and encompasses an area of about 3,608,400 $\mathrm{ft}^{2}$, or approximately 83 acres. Figure 5 illustrates the effect of depth on overall land-use restriction size.

The grid of previously mined coal accounts for all prior mining within the MTPRB assessment area, including those mines shown in figure 6 . The grid of counties contains locations of the five principal counties within this area (Big Horn, Custer, Powder River, Rosebud, and Treasure). The coal mineral ownership grid was divided into Federal, State, and private ownership categories (fig. 7). The resource reliability grid was divided into measured, indicated, inferred, and hypothetical coal categories and the coal bed depth grid was divided into four categories of depth: $0-500 \mathrm{ft} ; 500-1,000 \mathrm{ft}$; $1,000-2,000 \mathrm{ft}$; and greater than $2,000 \mathrm{ft}$.

The next step in the process was the application of these grids to the coal resources of the coal beds to be evaluated. First, the individual theme grids were combined into one composite theme grid, which was then used with the coal bed areal-extent grids to define the MTPRB assessment area resources on a bed-by-bed basis according to all the categories. Next, areas within each coal bed that represented previously mined coal and restrictions (land-use and technical) were removed from consideration.

For this assessment, regarding minable resources or potential reserves, coal resources were allocated to separate stripping-ratio areas for several coal beds. Figure 8 shows the composite stripping ratios for the Roland (Baker), Smith, Anderson, Dietz 2, and Dietz 3 coal beds. Figures 9-13 show the individual stripping ratio areas for the Canyon, Werner/ Cook, Pawnee, Rosebud/Knobloch, and Flowers-Goodale coal beds. These stripping ratios were determined before there was any prior mining; therefore, all of these coal beds represent potentially surface-minable resources within the foreseeable future (table 2). However, areas where these coal beds are less than $5 \mathrm{ft}$ thick are considered technically restricted for surface mining. Consequently, separate $\mathrm{PC} /$ Cores models were produced for these coal beds that excluded areas where the coal resources were less than $5 \mathrm{ft}$ thick and no mining potential was allocated to them. Table 3 shows recoverable resources based on restrictions (mining losses, land use, previously mined areas, and technical restrictions).

\section{Factors Affecting Extraction of Coal Resources}

Many factors can affect the availability of coal for mining. A four-step screening process, defined in the 43 CFR 3420.1-4 regulations, is used to determine which areas of federal coal are acceptable for leasing. The following list shows coal-leasing unsuitability criteria listed in the Code of Federal Regulations, Title 43 Subpart 3461.5 (43 CFR 3461.5) (Office of the Federal Register, 2003). 
Table 2. Available and recoverable resources of 10 beds at least $5.0 \mathrm{ft}$ thick and less than or equal to a 10:1 strip ratio in the Montana Powder River Basin assessment area. Resources reported in millions of short tons and include coal plus partings. Columns may not sum exactly because of rounding.

$[<$, less than; $>$, greater than; $\%$ percent $]$

\begin{tabular}{|c|c|c|c|c|c|c|c|c|c|c|c|c|}
\hline \multirow[b]{2}{*}{$\begin{array}{l}\text { Stripping } \\
\text { ratio }\end{array}$} & \multicolumn{12}{|c|}{ Coal bed name } \\
\hline & $\begin{array}{l}\text { Roland } \\
\text { (Baker) }\end{array}$ & Smith & Anderson & Dietz 2 & Dietz 3 & Canyon & Werner & Pawnee & $\begin{array}{l}\text { Rosebud/ } \\
\text { Knobloch }\end{array}$ & $\begin{array}{l}\text { Flowers- } \\
\text { Goodale }\end{array}$ & $\begin{array}{c}\text { Total } \\
\text { available }\end{array}$ & $\begin{array}{c}\text { Recoverable } \\
\text { resources } \\
(90 \%)\end{array}$ \\
\hline$<1: 1$ & 35 & 24 & 609 & 26 & 76 & 200 & 464 & 439 & 1,516 & 249 & 3,638 & 3,274 \\
\hline$>1: 1-2: 1$ & 28 & 19 & 688 & 19 & 91 & 162 & 366 & 250 & 1,521 & 180 & 3,324 & 2,992 \\
\hline$>2: 1-3: 1$ & 35 & 22 & 961 & 24 & 154 & 215 & 489 & 273 & 1,681 & 180 & 4,034 & 3,631 \\
\hline$>3: 1-4: 1$ & 39 & 26 & 1,124 & 27 & 269 & 254 & 667 & 261 & 1,402 & 174 & 4,243 & 3,819 \\
\hline$>4: 1-5: 1$ & 39 & 27 & 1,051 & 30 & 371 & 289 & 676 & 237 & 936 & 201 & 3,857 & 3,471 \\
\hline$>5: 1-6: 1$ & 39 & 28 & 1,039 & 33 & 367 & 335 & 704 & 231 & 719 & 197 & 3,692 & 3,323 \\
\hline$>6: 1-7: 1$ & 32 & 30 & 916 & 42 & 392 & 396 & 749 & 226 & 567 & 200 & 3,550 & 3,195 \\
\hline$>7: 1-8: 1$ & 29 & 32 & 832 & 50 & 392 & 489 & 840 & 236 & 636 & 215 & 3,751 & 3,376 \\
\hline$>8: 1-9: 1$ & 26 & 38 & 791 & 55 & 515 & 568 & 1,190 & 227 & 750 & 236 & 4,396 & 3,956 \\
\hline$>9: 1-10: 1$ & 26 & 41 & 690 & 55 & 636 & 571 & 1,370 & 237 & 772 & 238 & 4,636 & 4,172 \\
\hline Total & 328 & 287 & 8,701 & 361 & 3,263 & 3,479 & 7,515 & 2,617 & 10,500 & 2,070 & 39,121 & 35,209 \\
\hline
\end{tabular}


Table 3. Available and recoverable resources for 10 coal beds at least $5.0 \mathrm{ft}$ thick, reported by bed, for restrictions, recovery rates, mining losses, and recoverable resources for the Montana Powder River Basin assessment area (reported in millions of tons). Columns may not sum exactly because of rounding.

$[<$, less than; >, greater than; $\mathrm{ft}$, feet; \% percent]

\begin{tabular}{|c|c|c|c|c|c|c|c|c|c|}
\hline \multirow[b]{2}{*}{ Coal bed name } & \multirow{2}{*}{$\begin{array}{l}\text { Original } \\
\text { resources }\end{array}$} & \multirow{2}{*}{$\begin{array}{l}\text { Mined } \\
\text { out }\end{array}$} & \multicolumn{3}{|c|}{ Restrictions } & \multirow{2}{*}{$\begin{array}{l}\text { Available } \\
\text { resources } \\
\text { (<10:1 ratio) }\end{array}$} & \multirow{2}{*}{$\begin{array}{c}\text { Recovery rate } \\
(\%)\end{array}$} & \multirow{2}{*}{$\begin{array}{l}\text { Mining } \\
\text { losses }\end{array}$} & \multirow{2}{*}{$\begin{array}{c}\text { Recoverable } \\
\text { resources }\end{array}$} \\
\hline & & & Land use & $\begin{array}{c}\text { Technical } \\
\text { (2.5-5.0 ft thick) }\end{array}$ & $>10: 1$ ratio & & & & \\
\hline Roland (Baker) & 682 & 0 & 0 & 49 & 305 & 328 & 90 & 33 & 295 \\
\hline Smith & 1,778 & 0 & 19 & 183 & 1,289 & 287 & 90 & 29 & 258 \\
\hline Anderson & 15,027 & 472 & 992 & 104 & 4,758 & 8,701 & 90 & 870 & 7,831 \\
\hline Dietz 2 & 1,556 & 41 & 10 & 311 & 833 & 361 & 90 & 36 & 325 \\
\hline Dietz 3 & 8,757 & 136 & 1,036 & 506 & 3,816 & 3,263 & 90 & 326 & 2,937 \\
\hline Canyon & 18,895 & 0 & 3,189 & 226 & 12,001 & 3,479 & 90 & 345 & 3,134 \\
\hline Werner & 24,844 & 0 & 3,932 & 615 & 12,782 & 7,515 & 90 & 751 & 6,764 \\
\hline Pawnee & 13,563 & 0 & 2,494 & 1,568 & 6,884 & 2,617 & 90 & 262 & 2,355 \\
\hline Rosebud/Knobloch & 40,873 & 559 & 9,611 & 1,545 & 18,658 & 10,500 & 90 & 1,050 & 9,450 \\
\hline Flowers-Goodale & 25,518 & 0 & 631 & 610 & 22,207 & 2,070 & 90 & 207 & 1,863 \\
\hline Total & 151,493 & 1,208 & 21,914 & 5,717 & 82,533 & 39,121 & 90 & 3,909 & 35,173 \\
\hline
\end{tabular}




\section{Unsuitability Criteria}

Federal land systems

Rights-of-way and easements (for example, railroads)

Dwellings, roads, cemeteries, and public buildings

Wilderness study areas

Lands with outstanding scenic quality

Lands used for scientific study

Historic lands and sites

Natural areas

Critical habitat for threatened or endangered plant and animal species

State listed threatened or endangered species

Bald or golden eagle nests

Bald and golden eagle roost and concentration areas

Federal lands containing active falcon cliff nesting site

Habitat for migratory bird species

Fish and wildlife habitat for resident species

Flood plains

Municipal watersheds

National resource waters

Alluvial valley floors

State or Indian tribe proposed criteria

These 20 specific legal criteria are used to determine if an area is unsuitable for leasing and surface mining. The criteria were established by the Surface Mining Control and Reclamation Act (SMCRA) of 1977 (Public Law 95-87, 1977). The unsuitability criteria require consideration of land use, scenic areas, natural areas, historic sites, wildlife habitats, flood plains, alluvial valley floors, and other special lands. Although the 20 unsuitability criteria were developed for lands owned by the Federal government, many of the criteria would also be applicable to State-owned and privately-owned lands. For example, areas containing threatened or endangered plant or animal species are protected from destruction wherever they occur. Municipal watersheds are likewise protected from detrimental actions regardless of who owns the land. It is important to understand that not all criteria listed in the above list affect development within the MTPRB assessment area. Other potential restrictions to mining include land use restrictions such as, airports, archaeological areas, coalbed methane wells, oil and oil-related gas wells, pipelines, power lines, rivers, lakes, streams, and towns.

Restrictions to mining vary with location and local land-management regulations. Thus, areas can have different mining restrictions and availability considerations. This report reflects assumptions concerning restrictions to mining that are based on local practices in the PRB, and specifically to those practices within the MTPRB assessment area. In addition, U.S. Bureau of Land Management (BLM) personnel in Casper, Wyoming, provided guidance concerning restrictions to mining and the distances to be buffered around specific features. Because required buffer distances can change through time, distances were selected that were considered to be the maximum amount required by future regulations. A more detailed determination of restrictions and other availability considerations would be necessary as part of leasing and mineplanning phases of property development.
Figure 6 shows the areas within the MTPRB assessment area that were affected by restrictions. In some cases, an area that was originally declared unavailable for coal mining could have a mitigation measure that would permit mining. The following is a detailed discussion of potential mining restrictions for this area. All buffer restrictions refer to distances at the surface.

\section{Airports}

The Broadus Airport is located near Broadus, Montana, about $2.5 \mathrm{mi}$ northwest of the central business district. For this assessment, the airport (including a $300-\mathrm{ft}$ buffer surrounding the airport) is considered to be a restriction to mining. The Colstrip Airport is located about $4 \mathrm{mi}$ southwest of the central business district of Colstrip, Montana (fig. 6), on reclamation land that is surrounded by adjacent mining areas of the Rosebud Mine. Therefore, the current Colstrip Airport is not considered to represent a restriction to mining for this assessment.

\section{Alluvial Valley Floors}

All areas identified as alluvial valley floors where mining would interrupt, discontinue, or preclude farming by the state program delegated to enforce the Surface Mining Control and Reclamation Act of 1977 (Public Law 95-87, 1977), are unsuitable for surface coal mining and thus are deemed to be restrictions (fig. 6). In addition, areas outside alluvial valley floors where mining would materially damage the quantity or quality of water supplying alluvial valley floors are unsuitable; however, this analysis did not cover those areas.

\section{Archaeological Areas}

No major archaeological areas that would prevent mining are known in the MTPRB assessment area, but there are several minor archaeological sites and also several minor historic sites. A mitigation plan would be developed before coal mining disturbed these areas. Therefore, coal within these known sites was not excluded from this resource assessment.

\section{Coalbed Methane}

Coalbed methane (CBM) development in Montana began in 1991 and has proceeded at a much slower pace than in neighboring Wyoming. Just over 1,100 wells have been drilled in the MTPRB assessment area near the Decker Mine, along the Montana-Wyoming border (Montana Board of Oil and Gas, 2011), whereas over 30,000 wells have been drilled in the Wyoming portion of the PRB (Wyoming Oil and Gas Conservation Commission, 2011) (fig. 4). Production life of CBM wells is estimated to be about 10-12 years, although production from multiple beds can extend the life of the well by an additional 10-30 years (De Bruin and others, 2004).

Coalbed methane development in the MTPRB is restricted to a relatively small area in Big Horn County that includes T. 8-10 S., R. 39-41 E. (fig. 4). CBM production in 
the MTPRB assessment area is from the Smith, Anderson, Dietz 2, Dietz 3, Canyon, Werner/Cook, and Gates/Wall coal beds. There may be some potential for CBM production from deeper coal beds that could extend the CBM area northward. Van Voast and Thale (2001) identified areas of high, moderate, and low CBM potential for the Rosebud/Knobloch and Anderson-Dietz coal beds in the MTPRB assessment area (fig. 14). However, gas from the Rosebud/Knobloch has not yet been commercially produced, and the deeper FlowersGoodale coalbed methane has been produced with unimpressive results (Jay Gunderson, Montana Bureau of Mines and Geology, written commun., 2011).

The lack of expansion northward in Montana is because of a combination of less favorable coal bed targets, and increased distance from existing infrastructure. Coal beds in the MTPRB assessment area are not as well suited to CBM development as those in Wyoming because they lack the overall depth and thickness of coal beds in the central and southern PRB. Coal beds become shallower and eventually crop out to the north but, although this may be advantageous for surface mining, it is not beneficial for CBM development. Coal beds at shallow depths or near outcrop are likely to have lower hydrodynamic pressures (the pressures necessary to retain the adsorbed methane), which would allow methane gas in coal seams to migrate toward the outcrop and eventually escape.

Several conflicts have arisen between coal mining and coalbed methane development. One conflict involves the ownership of coalbed methane and whether it belongs to the owner of the oil-and-gas estate or the owner of the coal estate. The U.S. Supreme Court resolved this issue in 1999, ruling that coalbed methane is part of the oil-and-gas estate (Supreme Court of the United States, Amoco Production Co. v. Southern Ute Tribe (98-830), 526, U.S. 865 (1999). In addition, the court specified that the owner of the coalbed methane leases has the right to gain access and to develop its estate, and owners of the land surface should be adequately compensated for damage to their property resulting from coalbed methane extraction.

The BLM established Conflict Administration Zones to provide guidelines for (1) development of coalbed methane leases in the path of near-term coal mining, and (2) settling conflicts and scheduling development of each resource under a federal mineral estate. Although there are hundreds of CBM wells within the MTPRB, most of them are clustered in the southwestern part, to the south and east of the Spring Creek and Decker Mines (fig. 4). Designating all of these wells and their accompanying pipeline infrastructure as being restrictive to mining would exclude a significant volume of coal resource from mining consideration. For the purpose of this assessment, it is assumed that coal within any part of the MTPRB will be mined after CBM operations have ceased in that area; therefore, these facilities are not considered a restriction to mining.

\section{Dwellings and Buildings}

Individual dwellings and buildings that exist outside of incorporated areas (such as Colstrip) are not considered restrictions to mining within the MTPRB assessment area.
These individual structures could probably be purchased by a coal company, which could then move or raze them in order to proceed with mining.

\section{Federal Land Systems}

About 63 percent of the coal in the MTPRB assessment area is owned by the federal government and must be leased in order to be mined (table 4). The largest percentage of federally-owned area within the area is the Custer National Forest (fig. 6), which covers an area of $783 \mathrm{mi}^{2}$ in western Powder River County and southern Rosebud County and is situated about 1-1.5 mi to the east of the Northern Cheyenne Indian Reservation (fig. 1). The same unsuitability criteria and landuse conflicts that have been discussed apply to coal mining in the Custer National Forest; therefore, it represents a restriction to surface coal mining that includes a buffer extending out to a distance of $300 \mathrm{ft}$ beyond the forest boundary. However, the BLM could develop coal-leasing and mining stipulations in cooperation with the U.S. Forest Service for underground coal mining. Federal subsurface coal ownership is shown in figure 7. With respect to the Fort Keogh National Wildlife Refuge, located immediately to the southwest of Miles City, Montana, at the northern boundary of the assessment area (fig. 6), there are no coals that extend into that area.

\section{Historic Lands and Sites}

The site of the "Battle of Wolf Mountains" is about three mi southwest of Birney, Montana, along the valley of the Tongue Rive (fig. 6). This site is the location of the last major battle of the Great Sioux War of 1876-1877 and involves an area of hundreds of acres. In 2001, the battle site was added to the National Register of Historic Places. In 2008, it became a National Historic Landmark. Consequently, the 1,300-acre site is a restriction to mining for this assessment.

\section{Oil and Oil-Related Gas Wells}

Since the first gas discovery was made in 1913 near Hardin, Montana, nearly 2,000 oil and gas wells have been drilled in the Montana portion of the PRB. The Bell Creek field, discovered in 1965, is one of Montana's most prolific oil fields and lies along the southeastern margin of the MTPRB assessment area. Cumulative production is reported at over 135 million barrels of oil. Several smaller oil fields (less than 1 million barrels cumulative) are also along the eastern and western perimeters of the MTPRB (Montana Board of Oil and Gas, 2011).

The two largest gas fields near the MTPRB have cumulative production of about 3 billion cubic $\mathrm{ft}$ of gas each. They are Bell Creek South, adjacent to the Bell Creek oil field, and Liscom Creek, located in the north-central PRB along the Tongue River in T.1 N., R.45 E. and T.2 N., R.45 E. (Montana Board of Oil and Gas, 2011).

Infrastructure for production and transport of oil and gas in the area includes roads, pipelines, pump houses, and separators. Generally, there is little conflict between coal 
Table 4. Coal resources and restrictions for 18 beds greater than or equal to $2.5 \mathrm{ft}$ thick, reported in millions of short tons, by coal ownership categories for the Montana Powder River Basin assessment area. Resource includes coal plus partings. Totals may not sum exactly because of rounding.-Continued

\begin{tabular}{|c|c|c|c|c|c|c|c|c|c|}
\hline $\begin{array}{l}\text { Coal bed } \\
\text { name }\end{array}$ & $\begin{array}{c}\text { Coal } \\
\text { ownership }\end{array}$ & $\begin{array}{l}\text { Original } \\
\text { resource }\end{array}$ & $\begin{array}{c}\text { Burned } \\
\text { coal }\end{array}$ & $\begin{array}{l}\text { Remaining } \\
\text { resource }\end{array}$ & $\begin{array}{l}\text { Previously } \\
\text { mined coal }\end{array}$ & $\begin{array}{l}\text { Land use } \\
\text { restrictions }\end{array}$ & $\begin{array}{c}\text { Technical } \\
\text { restrictions }\end{array}$ & $\begin{array}{c}\text { Available } \\
\text { resource }\end{array}$ & $\begin{array}{c}\text { Percent } \\
\text { of total } \\
\text { remaining }\end{array}$ \\
\hline \multirow{4}{*}{ Roland (Baker) } & Federal & 643 & 11 & 632 & 0 & 0 & 44 & 588 & 86.1 \\
\hline & State & 46 & 2 & 44 & 0 & 0 & 4 & 40 & 5.9 \\
\hline & Private & 6 & 0 & 6 & 0 & 0 & 0 & 6 & 0.8 \\
\hline & Total & 695 & 12 & 682 & $\mathbf{0}$ & 0 & 49 & 634 & 92.8 \\
\hline \multirow{4}{*}{ Smith } & Federal & 1,694 & 37 & 1,657 & 0 & 18 & 164 & 1,474 & 82.9 \\
\hline & State & 97 & 1 & 96 & 0 & 0 & 14 & 82 & 4.6 \\
\hline & Private & 26 & 0 & 25 & 0 & 0 & 4 & 20 & 1.2 \\
\hline & Total & 1,817 & 38 & 1,778 & 0 & 18 & 183 & 1,577 & 88.7 \\
\hline \multirow{4}{*}{ Anderson } & Federal & 15,210 & 1,373 & 13,837 & 378 & 955 & 100 & 12,404 & 82.5 \\
\hline & State & 892 & 59 & 833 & 71 & 3 & 2 & 758 & 5.0 \\
\hline & Private & 379 & 23 & 356 & 23 & 34 & 2 & 297 & 2.0 \\
\hline & Total & 16,481 & 1,455 & 15,027 & 472 & 992 & 104 & 13,458 & 89.6 \\
\hline \multirow{4}{*}{ Dietz 2} & Federal & 1,405 & 29 & 1,376 & 32 & 2 & 291 & 1,052 & 67.6 \\
\hline & State & 89 & 4 & 85 & 9 & 0 & 17 & 59 & 3.8 \\
\hline & Private & 95 & 0 & 94 & 0 & 7 & 3 & 83 & 5.4 \\
\hline & Total & 1,590 & 33 & 1,556 & 41 & 10 & 311 & 1,194 & 76.7 \\
\hline \multirow{4}{*}{ Dietz 3} & Federal & 8,598 & 716 & 7,882 & 106 & 968 & 478 & 6,330 & 72.3 \\
\hline & State & 559 & 26 & 534 & 27 & 47 & 20 & 440 & 5.0 \\
\hline & Private & 359 & 18 & 342 & 4 & 21 & 8 & 309 & 3.5 \\
\hline & Total & 9,516 & 759 & 8,757 & 136 & 1,036 & 506 & 7,079 & 80.8 \\
\hline \multirow{4}{*}{ Canyon } & Federal & 17,930 & 436 & 17,494 & 0 & 3,093 & 213 & 14,188 & 75.1 \\
\hline & State & 978 & 15 & 963 & 0 & 66 & 10 & 888 & 4.7 \\
\hline & Private & 449 & 11 & 438 & 0 & 30 & 3 & 405 & 2.1 \\
\hline & Total & 19,357 & 462 & 18,895 & $\mathbf{0}$ & 3,189 & 226 & 15,480 & 81.9 \\
\hline \multirow{4}{*}{ Lower Canyon } & Federal & 9,623 & 235 & 9,388 & 0 & 1,814 & 933 & 6,641 & 65.5 \\
\hline & State & 529 & 11 & 518 & 0 & 52 & 42 & 423 & 4.2 \\
\hline & Private & 243 & 2 & 241 & 0 & 9 & 24 & 207 & 2.0 \\
\hline & Total & 10,395 & 249 & 10,146 & $\mathbf{0}$ & 1,875 & 1,000 & 7,272 & 71.7 \\
\hline
\end{tabular}


Table 4. Coal resources and restrictions for 18 beds greater than or equal to $2.5 \mathrm{ft}$ thick, reported in millions of short tons, by coal ownership categories for the Montana Powder River Basin assessment area. Resource includes coal plus partings. Totals may not sum exactly because of rounding.-Continued

\begin{tabular}{|c|c|c|c|c|c|c|c|c|c|}
\hline $\begin{array}{l}\text { Coal bed } \\
\text { name }\end{array}$ & $\begin{array}{c}\text { Coal } \\
\text { ownership }\end{array}$ & $\begin{array}{l}\text { Original } \\
\text { resource }\end{array}$ & $\begin{array}{c}\text { Burned } \\
\text { coal }\end{array}$ & $\begin{array}{l}\text { Remaining } \\
\text { resource }\end{array}$ & $\begin{array}{l}\text { Previously } \\
\text { mined coal }\end{array}$ & $\begin{array}{l}\text { Land use } \\
\text { restrictions }\end{array}$ & $\begin{array}{l}\text { Technical } \\
\text { restrictions }\end{array}$ & $\begin{array}{l}\text { Available } \\
\text { resource }\end{array}$ & $\begin{array}{c}\text { Percent } \\
\text { of total } \\
\text { remaining }\end{array}$ \\
\hline \multirow{4}{*}{ Ferry } & Federal & 2,205 & 7 & 2,199 & 0 & 308 & 476 & 1,414 & 57.6 \\
\hline & State & 156 & 0 & 156 & 0 & 1 & 22 & 134 & 5.5 \\
\hline & Private & 100 & 0 & 100 & 0 & 6 & 11 & 82 & 3.3 \\
\hline & Total & 2,462 & 7 & 2,454 & $\mathbf{0}$ & 315 & 509 & 1,630 & 66.4 \\
\hline \multirow{4}{*}{ Werner/Cook } & Federal & 23,616 & 704 & 22,913 & 0 & 3,848 & 558 & 18,506 & 74.5 \\
\hline & State & 1,076 & 26 & 1,050 & 0 & 49 & 33 & 967 & 3.9 \\
\hline & Private & 914 & 32 & 882 & 0 & 35 & 23 & 824 & 3.3 \\
\hline & Total & 25,606 & 762 & 24,844 & $\mathbf{0}$ & 3,932 & 615 & 20,297 & 81.7 \\
\hline \multirow{4}{*}{ Otter } & Federal & 4,163 & 62 & 4,101 & 0 & 800 & 1,516 & 1,785 & 40.5 \\
\hline & State & 215 & 0 & 215 & 0 & 24 & 104 & 86 & 2.0 \\
\hline & Private & 96 & 2 & 94 & 0 & 11 & 29 & 55 & 1.2 \\
\hline & Total & 4,474 & 64 & 4,410 & $\mathbf{0}$ & 835 & 1,649 & 1,926 & 43.7 \\
\hline \multirow{4}{*}{ Gates/Wall } & Federal & 7,567 & 117 & 7,450 & 0 & 790 & 1,567 & 5,093 & 62.6 \\
\hline & State & 340 & 1 & 339 & 0 & 7 & 59 & 273 & 3.4 \\
\hline & Private & 350 & 2 & 348 & 0 & 6 & 52 & 290 & 3.6 \\
\hline & Total & 8,257 & 121 & 18,137 & $\mathbf{0}$ & 802 & 1,678 & 5,656 & 69.5 \\
\hline \multirow{4}{*}{ Pawnee } & Federal & 12,563 & 248 & 12,314 & 0 & 2,438 & 1,438 & 8,438 & 62.2 \\
\hline & State & 596 & 4 & 592 & 0 & 14 & 85 & 492 & 3.6 \\
\hline & Private & 676 & 19 & 657 & 0 & 41 & 45 & 571 & 4.2 \\
\hline & Total & 13,834 & 271 & 13,563 & $\mathbf{0}$ & 2,494 & 1,568 & $\mathbf{9 , 5 0 1}$ & 70.1 \\
\hline \multirow{4}{*}{ Odell } & Federal & 1,618 & 23 & 1,594 & 0 & 297 & 892 & 404 & 22.7 \\
\hline & State & 69 & 0 & 68 & 0 & 1 & 43 & 25 & 1.4 \\
\hline & Private & 118 & 2 & 116 & 0 & 0 & 96 & 20 & 1.1 \\
\hline & Total & 1,803 & 26 & 1,778 & 0 & 298 & 1,031 & 449 & 25.3 \\
\hline \multirow{4}{*}{ Rosebud/Knobloch } & Federal & 31,513 & 744 & 30,769 & 243 & 8,728 & 1,346 & 20,452 & 50.0 \\
\hline & State & 1,353 & 118 & 1,235 & 11 & 44 & 88 & 1,092 & 2.7 \\
\hline & Private & 9,749 & 881 & 8,869 & 305 & 839 & 111 & 7,614 & 18.6 \\
\hline & Total & 42,616 & 1,743 & 40,873 & 559 & 9,611 & 1,545 & 29,158 & 71.3 \\
\hline
\end{tabular}


Table 4. Coal resources and restrictions for 18 beds greater than or equal to $2.5 \mathrm{ft}$ thick, reported in millions of short tons, by coal ownership categories for the Montana Powder River Basin assessment area. Resource includes coal plus partings. Totals may not sum exactly because of rounding.-Continued

\begin{tabular}{|c|c|c|c|c|c|c|c|c|c|}
\hline $\begin{array}{c}\text { Coal bed } \\
\text { name }\end{array}$ & $\begin{array}{c}\text { Coal } \\
\text { ownership }\end{array}$ & $\begin{array}{l}\text { Original } \\
\text { resource }\end{array}$ & $\begin{array}{c}\text { Burned } \\
\text { coal }\end{array}$ & $\begin{array}{l}\text { Remaining } \\
\text { resource }\end{array}$ & $\begin{array}{l}\text { Previously } \\
\text { mined coal }\end{array}$ & $\begin{array}{l}\text { Land use } \\
\text { restrictions }\end{array}$ & $\begin{array}{l}\text { Technical } \\
\text { restrictions }\end{array}$ & $\begin{array}{l}\text { Available } \\
\text { resource }\end{array}$ & $\begin{array}{c}\text { Percent } \\
\text { of total } \\
\text { remaining }\end{array}$ \\
\hline \multirow{4}{*}{ McKay/Nance } & Federal & 6,867 & 85 & 6,782 & 0 & 766 & 1,577 & 4,439 & 42.9 \\
\hline & State & 482 & 11 & 471 & 6 & 9 & 80 & 376 & 3.6 \\
\hline & Private & 3,201 & 101 & 3,100 & 62 & 128 & 274 & 2,635 & 25.4 \\
\hline & Total & 10,549 & 196 & 10,353 & 68 & 903 & 1,932 & 7,450 & 72.0 \\
\hline \multirow{4}{*}{ Flowers-Goodale } & Federal & 20,619 & 85 & 20,535 & 0 & 349 & 461 & 19,724 & 77.3 \\
\hline & State & 1,055 & 10 & 1,045 & 0 & 58 & 26 & 961 & 3.8 \\
\hline & Private & 4,012 & 74 & 3,938 & 0 & 223 & 123 & 3,592 & 14.1 \\
\hline & Total & 25,686 & 169 & 25,518 & 0 & 631 & 610 & 24,277 & 95.1 \\
\hline \multirow{4}{*}{ Robinson/Witham } & Federal & 5,112 & 10 & 5,102 & 0 & 4 & 1,500 & 3,598 & 38.3 \\
\hline & State & 387 & 6 & 381 & 0 & 0 & 66 & 315 & 3.3 \\
\hline & Private & 4,064 & 144 & 3,919 & 0 & 0 & 221 & 3,699 & 39.3 \\
\hline & Total & 9,562 & 160 & 9,402 & $\mathbf{0}$ & 4 & 1,786 & 7,612 & 81.0 \\
\hline \multirow{4}{*}{ Roberts/Terret } & Federal & 7,811 & 60 & 7,752 & 0 & 49 & 1,748 & 5,955 & 56.9 \\
\hline & State & 476 & 3 & 473 & 0 & 1 & 120 & 353 & 3.4 \\
\hline & Private & 2,311 & 65 & 2,246 & 0 & 45 & 588 & 1,614 & 15.4 \\
\hline & Total & 10,599 & 128 & 10,471 & 0 & 95 & 2,455 & 7,921 & 75.6 \\
\hline \multirow{4}{*}{ Total } & Federal & 178,758 & 4,982 & 173,776 & 759 & 25,229 & 15,303 & 132,485 & 63.5 \\
\hline & State & 9,396 & 297 & 9,099 & 123 & 377 & 838 & 7,761 & 3.7 \\
\hline & Private & 27,145 & 1,377 & 25,768 & 394 & 1,436 & 1,616 & 22,323 & 10.7 \\
\hline & Total & 215,300 & 6,656 & 208,644 & 1,277 & 27,042 & 17,757 & 162,568 & 77.9 \\
\hline
\end{tabular}


development and conventional oil and gas development in the MTPRB assessment area, as oil and gas reservoirs are primarily in stratigraphic units below minable coal beds. Where there is oil and gas development and coal mining in the same areas, mining is confined to areas outside a specific buffer distance from wells, pipelines, and other oil- and gas-related facilities.

Resolution of land-use conflicts between coal mining and oil and gas field development depends on economic conditions, regulations, and negotiations between oil developers and coal developers. An area around a major cluster of active wells might be eliminated from mining activities until these wells are no longer actively producing, or mining activities might proceed around individual active wells that are given a buffer zone. Conversely, specific wells might be plugged and then reestablished after mining. For this assessment, it was assumed that the wells will no longer be actively producing when mining operations reach them and thus they are not considered to be restrictions to mining.

\section{Pipelines}

There are underground oil and gas pipelines within the MTPRB assessment area. Presumably most, if not all, could be moved to allow surface mining. However, moving and restoring them would represent an added economic cost to mining. In any case, pipelines were not considered to be restrictions to mining for this assessment.

\section{Power Lines}

All power lines within the assessment area could be moved to accommodate surface mining operations. Thus, power lines are not considered a restriction to mining in the MTPRB assessment area.

\section{Railroads}

The main railroad route through the MTPRB assessment area is an east-west rail section of the Burlington Northern Santa Fe Railway that is located in the extreme northern part of the assessment area (figs. 1, 6); it is not considered a restriction because coal beds do not extend into that part of the assessment area. In addition, there are three spur railroad lines that do traverse land underlain by coal. Two of these are in the northern part of the assessment area connecting the main railroad line and extending south to the Absaloka and Rosebud Mines. The third connects to a section of the main railroad line of the Burlington Northern Santa Fe Railway to the south (near Sheridan, Wyoming) and extends north to the Decker and Spring Creek Mines (fig. 1). It is assumed that the spur railroad lines would be moved as necessary for mining; therefore, they are not considered to be restrictions to mining.

\section{Rivers, Lakes, and Streams}

The Powder River and the Tongue River are the longest courses of flowing water within the MTPRB assessment area. They are shallow, slow moving, meandering streams, as is the case with all of the perennial stream tributaries and other creeks in the area. Therefore, surface-mining operations could temporarily divert the stream channels and then return them to their pre-mining locations as part of mine reclamation. The parts of these water courses that are designated by the Montana State Land Quality Division as alluvial valley floors significant to farming, however, would be exempt from mining. The relatively broad valley of the Yellowstone River lies in the extreme northern part of the assessment area, but has no restriction effect on mining because the coals do not extend into that area.

Shallow lakes and small ponds that do exist within the MTPRB could either be temporarily moved during mining or simply reformed after the mining operations ceased. However, the Tongue River Reservoir, a recreational site and water-supply source located about 2.5 mi northeast of Decker, Montana, is considered to be a restriction to mining for this assessment (fig. 6). The restriction includes a 100-ft buffer surrounding the lake.

\section{Roads}

County roads (mostly gravel) cross many areas throughout the MTPRB assessment area. These roads are not considered to restrict mining because they could be easily relocated or temporarily blocked off to allow mining to proceed. In addition, a number of State and U.S. highways, including Interstate Highway 94, are present within the area (fig. 6). For this study, it is assumed that all of these highways would also be relocated to allow for mining, except for the interstate highway. However, like the main railroad line, the interstate highway lies in the extreme northern part of the assessment area and has no restriction effect on the coal beds because the coals do not extend into that part of the area.

\section{State Lands and Trusts}

Two state parks are situated within the MTPRB assessment area: the Rosebud Battlefield State Park and the Tongue River Reservoir State Park (fig. 6); both parks are considered to be restrictions to mining. The Rosebud Battlefield State Park is about 15 mi northwest of Decker, Montana, and the Tongue River Reservoir State Park is about 6 mi northeast of Decker. The restriction for each park includes a buffer that extends out to a distance of $300 \mathrm{ft}$ beyond the park boundaries.

Also within the assessment area are a fishing access site (at Twelve Mile Dam) and two conservation easements (fig. 6). The fishing access site and one of the easements are under the jurisdiction of the Montana Fish, Wildlife \& Parks. The other conservation easement is overseen by the Montana Land Reliance. These lands are considered to be restricted from mining; however, they have no restriction effect on the coal beds because the coals do not extend into their locations within the northern part of the assessment area.

\section{Towns}

The municipalities of Colstrip and Broadus are located within the MTPRB assessment area and are permanently 
restricted from mining (fig. 6). In addition to the actual incorporated areas, the mining restriction for each municipality includes a buffer that extends out to a distance of $300 \mathrm{ft}$ beyond the municipality limits.

\section{Coal Quality}

Coal quality is one of the major factors in the marketability of coal and is an important parameter in economic evaluations, as coal is sold based on its calorific value expressed in British thermal units per pound (Btu/lb). Quality parameters such as increased ash content, which lowers the calorific value, negatively effects the operating and maintenance costs at coal-fired power plants. Therefore, coals with lower ash and sulfur content and higher calorific values command a premium selling price.

The Clean Air Act Amendments have enforced emission limits to reduce certain air pollutants such as sulfur dioxide. The sulfur dioxide emissions limits for all new coal-fired power plants built after 1976 were capped at 1.2 pounds (lbs) of sulfur dioxide per million Btu (U.S. Environmental Protection Agency, 1980). Any coal that could be burned and meet the sulfur dioxide emission standards for air quality (emits less than $0.6 \mathrm{lbs}$ or less sulfur per million Btu or $1.2 \mathrm{lbs}$ of sulfur dioxide per million Btu) without the need for flue-gas desulfurization was designated "compliance coal," also known as low-sulfur coal (U.S. Energy Information Administration, 2010). Subsequent phases of the Clean Air Act Amendments have further restricted sulfur dioxide emissions. Also, new Source Performance Standards establish uniform national Environmental Protection Agency air-emission standards that limit the amount of pollution from new sources or from modified existing sources. Under New Source Performance Standards, Best Available Control Technology emission limitations are based on the maximum degree of reduction of each pollutant subject to regulation under the Clean Air Act Amendments (U.S. Environmental Protection Agency, 2005). The minimum Best Available Control Technology standard for sulfur dioxide emissions is 90 percent regardless of the sulfur content.

Coal quality information has been available since the early 1970s from five mines in the MTPRB (Absaloka, Big Sky, Decker, Rosebud, and Spring Creek). Table 5 summarizes coal quality for those five mines and the Otter Creek lease area. Coal quality data was summarized by Roberts and others [1999a, 1999b, 1999c, after Matson and Blumer (1973)] or select areas within the MTPRB assessment area (fig. 15, table 6). Results for individual coal beds in coal fields and areas were reported in ranges, whereas results for the Absaloka Mine area (table 6) were reported as averages. Within the MTPRB assessment area, sulfur ranged from 0.1-7.2 percent, ash content ranged from $2.5-12.6$ percent, and the Btu/lb values ranged from 6,019-9,850.

In comparison to coal mined in the Wyoming portion of the PRB, coal in the MTPRB assessment area is generally higher in sodium content (table 7). High sodium content in coal can cause excessive slagging in most power plant boilers and therefore is marketed to power plants with specially designed boilers. Coal beds (Anderson, Dietz 2, Dietz 3) in the Decker and Spring Creek Mine areas have higher sodium content than coals (Rosebud/Knobloch coal bed) in the Rosebud and Absaloka Mine areas (table 7). Coal within the Tongue River Member of the Fort Union Formation is mainly classified as subbituminous B to lignite A, based on heatof-combustion values (Gilmour and Dahl, 1967). Although there is a general decrease in coal rank from west to east, the transition is gradual (fig. 15). Because the MTPRB assessment area contains mostly subbituminous B coal, all resources were calculated using 1,770 tons per acre-foot.

Table 5. Available as-received coal-quality data for mines and mine leases in the Montana Powder River Basin assessment area.

[BTU/lb, Thermal Unit/pound]

\begin{tabular}{lcccc}
\hline \multicolumn{1}{c}{ Mine name } & $\begin{array}{c}\text { Ash } \\
\text { (percent) }\end{array}$ & $\begin{array}{c}\text { Sulfur } \\
\text { (percent) }\end{array}$ & $\begin{array}{c}\text { Moisture } \\
\text { (percent) }\end{array}$ & $\begin{array}{c}\text { Calorific value } \\
\text { (Btu/lb) }\end{array}$ \\
\hline Absaloka Mine $^{1}$ & 9.1 & 0.68 & 24.5 & 8,687 \\
Big Sky Mine $^{2}$ & 8.8 & 0.75 & 25.9 & 8,750 \\
Decker Mines $^{1}$ & 4.4 & 0.38 & 23.8 & 9,500 \\
Rosebud Mine $^{1}$ & 9.1 & 0.74 & 25.9 & 8,529 \\
Spring Creek Mine $^{1}$ & 4.1 & 0.34 & 25.4 & 9,350 \\
Otter Creek (Arch lease) $^{3}$ & 5.5 & 0.15 & ----- & 8,110 \\
\hline
\end{tabular}

${ }^{1}$ From Wilde, 2010

${ }^{2}$ From Wilde, 2001

${ }^{3}$ From Culbertson and Saperstone, 1987. 
Table 6. Available as-received coal-quality data for coal fields and areas in the Montana Powder River Basin assessment area (see fig. 15 for locations).

[All data from Roberts and others (1999a, 1999b, 1999c; BTU/lb, British Thermal Unit/pound]

\begin{tabular}{llccc}
\hline \multicolumn{1}{c}{ Coal field or area name } & Bed name & $\begin{array}{c}\text { Sulfur } \\
\text { (percent) }\end{array}$ & $\begin{array}{c}\text { Ash } \\
\text { (percent) }\end{array}$ & $\begin{array}{c}\text { Calorific value } \\
\text { (Btu/lb) }\end{array}$ \\
\hline Ashland coal field & Knobloch & $0.1-0.5$ & $3.7-6.8$ & $7,761-9,070$ \\
Foster Creek area & Knobloch & $0.3-1.6$ & $6.7-8.7$ & $7,380-7,840$ \\
Greenleaf Creek-Miller Creek area & Knobloch & $0.42-0.44$ & $5.5-6.7$ & $8,209-8,935$ \\
Absaloka Mine area & Robinson & 0.79 & 7.88 & 8,665 \\
Absaloka Mine area & McKay & 0.89 & 8.83 & 8,642 \\
Absaloka Mine area & Rosebud & 0.65 & 8.24 & 8,767 \\
Colstrip coal field & Rosebud & $0.53-7.20$ & $7.86-12.58$ & $7,810-9,090$ \\
Decker/Spring Creek area & Anderson & $0.1-0.9$ & $3.0-9.1$ & $6,594-9,850$ \\
Decker/Spring Creek area & Dietz 2, 3 & $0.1-2.4$ & $2.5-14.1$ & $6,019-9,561$ \\
Decker/Spring Creek area & Canyon & $0.1-2.5$ & $3.2-10.7$ & $6,646-9,113$ \\
\hline
\end{tabular}

Table 7. Comparison of proximate analysis of coals from mines in the Wyoming and Montana portions of the Powder River Basin.

[All data from Guide to Coal Mines, April 21, 2010; BTU/lb, British Thermal Unit/pound]

\begin{tabular}{lcccc}
\hline \multicolumn{1}{c}{ Mine name } & Sodium as percent of ash & $\begin{array}{c}\text { Sulfur } \\
\text { (percent) }\end{array}$ & $\begin{array}{c}\text { Ash } \\
\text { (percent) }\end{array}$ & $\begin{array}{c}\text { Calorific value } \\
\text { (Btu/lb) }\end{array}$ \\
\hline Wyoming mines & 1.64 & & & 8,800 \\
Antelope & 1.90 & 0.24 & 4.50 & 8,550 \\
Belle Ayr & 1.30 & 0.33 & 5.50 & 8,800 \\
Black Thunder & 1.80 & 0.30 & 5.00 & 8,400 \\
Buckskin & 1.40 & 0.30 & 5.10 & 8,500 \\
Cabbalo & 1.40 & 0.34 & 5.40 & 8,400 \\
Codero Rojo & 1.90 & 0.34 & 4.50 & 8,400 \\
Eagle Butte & 1.60 & 0.34 & 5.40 & 8,300 \\
Rawhide & & 0.37 & & 8,750 \\
Montana mines & 2.00 & & 9.00 & 9,450 \\
Absaloka & $1.00-8.00$ & 0.60 & 4.20 & 8,750 \\
Decker & 0.30 & 0.40 & 8.50 & 9,350 \\
Rosebud & 8.50 & 0.80 & 4.10 & \\
Spring Creek & & 0.38 & & \\
\hline
\end{tabular}




\section{Mine Model Methodology}

Mine models were developed to determine the recoverable potential of coal resources in the MTPRB assessment area. Both surface and underground mine models included simplified algorithms for determining required equipment rates and sizes to cut, load, and convey burden and coal. These calculations were embedded in interlocking spreadsheets (Microsoft 2007 EXCEL $^{\circledR}$ ) which are used to correlate equipment requirements with personnel, supply, and facility physical needs. Unit costs that were available through InfoMine USA, Inc. (2010) were applied to these physical parameters and adjusted to their time-value for determination of the total project net present value on a case-by-case basis.

Information from four surface coal mines operating in the MTPRB assessment area was used to develop a surface-mine model to accommodate localized geologic conditions. Each of these mines is unique as related to individual corporate policy affecting the design of each mine.

Reserves in the Gillette coalfield (Luppens and others, 2008) and the Northern Wyoming Powder River Basin assessment area (Scott and others, 2010) were evaluated using the USGS software program CoalVal (Rohrbacher and McIntosh, 2010). Both of these areas involved single coal bed modeling for which CoalVal was designed. Modeling for multiple coal beds in the MTPRB assessment area was evaluated using the approach described in the Appendix of this report. The results of both evaluation methodologies are considered to be adequate representations of industry practice.

The methodology of parsing out the coal resources by composite stripping-ratio increments used in the Gillette coal field assessment (Luppens and others, 2008) was also used in the MTPRB assessment area. However, with more beds that have a thinner average thickness throughout a larger stratigraphic interval, the approach to the coal reserve evaluation model for the MTPRB assessment area had to be modified from the composited single seam approach used for the Gillette coal field. Further complicating the development of a regional mining model for this area is the fact that not all beds are everywhere present. Mine models and assumptions for both surface and underground reserve analysis are given in the Appendix at the end of this report.

\section{Geologic Setting}

The Powder River Basin is an elongate, north-northwesttrending sedimentary basin that covers about $22,000 \mathrm{mi}^{2}$ of northeastern Wyoming and southeastern Montana (fig. 16). It forms a broad asymmetric syncline with a gently dipping east limb and a more steeply dipping west limb. The synclinal axis lies near the basin's western margin, trending north-northwest in the Wyoming portion of the PRB, and gradually turning north-northeasterly in the Montana portion (Lopez, 2005). The Montana portion of the basin is bounded by structural uplifts - the Bighorn Mountains to the west, and the Black
Hills to the east. The basin becomes shallow to the north against the south flank of the Miles City arch. Two systems of northeast-trending faults are present in the MTPRB assessment area (fig. 17), and may represent extensions of the Lake Basin and Nye-Bowler fault zones (Vuke and others, 2001a, 2001b; Lopez and Heath, 2007).

Strata exposed at the surface in the MTPRB assessment area consist almost entirely of the lower Tertiary (Paleocene) Fort Union Formation (fig. 18). The Fort Union Formation is composed of three members; from oldest to youngest, the Tullock, Lebo (informally referred to as the Lebo shale), and Tongue River Members. Together, they form a thick sequence of interbedded sandstones, conglomerates, siltstones, shales, and coals. The deposition of clastic sediments that produced these units was accompanied by tremendous accumulations of peat in nearby low-energy environments such as flood plains and swamps. In the MTPRB assessment area, the Fort Union Formation ranges in thickness from a few hundred feet in the north to approximately $4,000 \mathrm{ft}$ at the Montana-Wyoming border (Jay Gunderson, Montana Bureau of Mines and Geology, written commun., 2011).

Underlying the Fort Union Formation, delta-plain sandstones and shales of the Upper Cretaceous Hell Creek Formation (equivalent to the Lance Formation in Wyoming) grade upward into the fluvial-dominated strata of the lowermost Tullock Member of the Fort Union Formation. The top of the Hell Creek Formation is placed at the base of the lowest coal bed in the Tullock Member (Brown, 1993), and generally corresponds to an upward change in sedimentary character from cross-bedded to planar-bedded sandstones (Vuke and others, 2001c). The Hell Creek Formation and older marine and nonmarine sedimentary units that underlie the Fort Union Formation are only exposed along the basin margins.

The Eocene Wasatch Formation in some areas unconformably overlies the Fort Union Formation and crops out only in the southernmost part of the MTPRB assessment area, along topographic highs between stream valleys including the Tongue River, Hanging Woman Creek, and Otter Creek (Vuke and others, 2001b). The contact between the two formations is identified, in part, by the distinctive heavy mineral suites in each (Denson and others, 1990).

Coal beds are present in all three members of the Fort Union Formation and in the Wasatch Formation in the MTPRB assessment area. The Fort Union Formation contains some of the thickest and most extensive deposits of subbituminous coal in the world (Molnia and Pierce, 1992). The most important beds are in the Tongue River Member of the Fort Union Formation. This unit has as many as 26 coal beds, some of which attain thicknesses as much as $80 \mathrm{ft}$. Progressively older coal beds become exposed at the surface to the north because of their south-dips combined with the drop in surface elevation to the north. The largest volume of coal is in the Wyodak-Anderson coal zone in the Tongue River (Flores and others, 1999), which contains the equivalent (in descending order) of the Smith, Anderson, Dietz 2, Dietz 3, Canyon, Lower Canyon, Ferry, and Werner/Cook (fig. 19). 
Cross sections A-A' to $\mathrm{G}-\mathrm{G}^{\prime}$ in figs. 20 to 27 illustrate the coal bed geometry and stratigraphic sequence of the lower Tongue River Member coal beds. Generally, coal beds below the Wyodak-Anderson coal zone that are present in eastern Montana tend to be thinner and more discontinuous, with the exception of the Pawnee, Rosebud/Knobloch, and FlowersGoodale (fig. 19).

Clinker, which is widespread, and geologic structure, on a more local scale, exerts varying effects on resource development. Almost everywhere in the MTPRB, coal beds more than $5 \mathrm{ft}$ thick have burned. The heat produced brightly colored material known as clinker-rocks that overlie a burned coal bed and were altered, baked, and fused. The clinker affects a thickness of the overlying material that is roughly 2-3 times the original thickness and quantity of the coal that has burned. Thickness of clinker can therefore be used in exploration as an added indication of the thickness of a coal bed. A coal bed 5-10 $\mathrm{ft}$ thick can produce a clinker zone 10-30 ft thick, whereas a coal bed $50 \mathrm{ft}$ thick may produce a clinker zone 100-200 ft thick (Matson and Blumer, 1973).

Large areas of original near-surface coal resources have been destroyed by burning at their outcrop and beneath shallow cover. Approximately $1,000 \mathrm{mi}^{2}$ of the surface area in the MTPRB is affected by clinker (Coates and Heffern, 1999) (fig. 28). Roberts and others (1999c) outlined large areas of clinker in the Spring Creek and Decker Mine area affecting the Anderson, Dietz 2, and Dietz 3 coal beds. In the Rosebud Mine area, where the Rosebud and McKay beds merge to form a single bed, clinker deposits have been reported to attain a thickness of as much as $120 \mathrm{ft}$ (Tudor, 1975).

The amount of burned coal was subtracted from the amount of the original coal resource. To calculate the amount of coal that has been burned, it was assumed that there is up to a three-to-one ratio of clinker thickness to burned coal thickness (Coates and Heffern, 1999). Consequently, to estimate the areas of coal within each bed that had been burned, a combination of surface clinker extent, coal overburden thickness, and coal bed thickness was used during the GIS analysis. Specifically, wherever surface clinker lies over a coal bed and the thickness of the overburden is three times (or less) the thickness of the coal, the coal within the bed was considered to be completely burned. Nevertheless, this procedure probably produces a conservative estimate of the amount of burned coal throughout the MTPRB assessment area. The total volume of clinker is estimated to be about 7 BST.

The structural dip of coal beds can affect the type of mining of those beds. A dip of $5^{\circ}$, for example, has much less effect on both surface and underground mining, than does a dip of $20^{\circ}$ or greater. The dip of coal beds in the Spring Creek, Decker, and Rosebud Mine areas is generally less than $5^{\circ}$, with dip orientations varying from southeasterly to southwesterly. However, dips are steepened by high-angle normal faults that are present in the western half of the MTPRB assessment area. Figures 21 and 22 illustrate the gentle dip of coal beds in the eastern part of the PRB in contrast to the steeper dip of the same beds along the west margin of the basin.
In the southwestern part of the MTPRB assessment area, numerous northeast-trending faults are present in the northward extension of the Sheridan coal field (fig. 17). The faults, most of which are downthrown on the east, postdate coalbed formation. Faults shown in figure 17 are based on Ellis and others (1999a, b) and Roberts and others (1999c), or they were identified during the correlation phase of this study from observations of stratigraphic offset between drill holes. The faults in the western part of the MTPRB range from 0.5-6.0 $\mathrm{mi}$ in length, with displacements of as much as $140 \mathrm{ft}$ (Robinson and Van Gosen, 1986). In most cases, fault displacement is not much more than $100 \mathrm{ft}$. Areas where numerous high-angle faults are present are not conducive to either surface or underground mining operations.

Faults in coal beds also have an important effect on the selection of mining methods and on productivity. Major faults with vertical displacements greater than $65 \mathrm{ft}$ commonly are used to delineate mine plan boundaries. Numerous minor faults are generally associated with and trend almost parallel to major faults. The adverse effects of faulting are greater on underground mining operations. Whereas a fault with a vertical displacement of 3-16 ft may not pose much of a problem in a surface mine, it may be a serious impediment in underground mining (Thomas, 2002).

The method of underground mining affects the amount of resources lost to faults. If the method used is longwall mining, there will be a larger resource loss because longwall operations need hazard-free runs in a designated panel of coal. Longwall panels are typically 5,000-10,000 ft in length and $750-1,500 \mathrm{ft}$ in width; thus, a large, relatively unfaulted block of coal is required. Also to be considered is the amount the faulted coal bed is displaced out of line with the preset coal shearer. If coal panels between faults are too small, then whole blocks may be lost to mining (Thomas, 2002).

\section{Coal Bed Correlations and Nomenclature}

Because coal beds commonly split, merge, and pinch out, the correlation of individually named coal beds and coal zones across the PRB has been difficult (Flores and others, 1999). Also, distances between individual drill holes can be large, increasing the uncertainty in correlating coal beds from one drill hole to the next. Some reports relied on drill-hole data that were 10 or more miles apart. However, with the drilling and development of new CBM in the PRB, data from thousands of new drill holes are now available, and the distance between drill holes is thus reduced (fig. 4).

The graphical interface of the StratiFact (GRG Corporation, 1998) database was a critical tool for managing interpretation of the large amount of existing information across the MTPRB assessment area. Using StratiFact, on-screen cross sections were selected, edited, and correlated. Both linear and circular cross sections were constructed to correlate coal 
beds; the circular cross sections, in which both the beginning and ending drill holes are the same, were especially valuable in maintaining accuracy in the tracing of individual beds and avoid miscorrelation.

Various names for individual coal beds and coal zones in the PRB have been used during the past 30 years (fig. 19). A report by Kent and others (1980), who described the northern part of the Gillette coal field that falls within the Spotted Horse coal field of Olive (1957), established a coal bed nomenclature system that has become the standard for much of the PRB in Wyoming and Montana. Molnia and Pierce (1992) also described coal bed stratigraphy in the central PRB in Wyoming and Montana; their nomenclature follows the usage of Culbertson and others (1979), Law and others (1979), Kent and others (1980), and Culbertson (1987).

In the area of the Absaloka, Big Sky, and Rosebud Mines, coal bed nomenclature for this assessment in the MTPRB is generally consistent with the terminology of Dobbin (1929) and nomenclature adhered to in subsequent studies by Matson and Blumer (1973), Tudor (1975), Robinson and Van Gosen (1986), and Derkey (1986).

Coal bed nomenclature for the Spring Creek and Decker Mine areas generally follows that of Roberts and others (1999b). Within the Spring Creek and Decker Mine area, Roberts and others (1999b) described the Anderson-Canyon coal zone, which is equivalent to the Wyodak-Anderson coal zone of Flores and Bader (1999) that contains the Anderson, Dietz 2, Dietz 3, Cox, and Canyon coal beds. Coal beds of the same name in this assessment correlate with the coal bed names in the Wyodak-Anderson coal zone; coal bed names used in this report and the equivalent names used in previous reports are shown in figure 19. The stratigraphic sequence of all 26 beds is shown in figure 29 .

Guidelines were established regarding which nomenclature would be used when two named beds merge into a single bed. The general correlation guidelines used for this assessment are as follows:

1. Two named beds are considered to have merged into a single named bed when the intervening parting is less than $2 \mathrm{ft}$ thick. The following exceptions were made for modeling purposes:

- In individual holes, coal beds split by partings as much as $5 \mathrm{ft}$ thick are considered merged if nearby surrounding holes indicate the beds have merged into a single bed.

- In individual holes, coal beds with no partings or partings less than $2.0 \mathrm{ft}$ thick are considered split into two beds if surrounding holes show the coal has split into two beds.

2. The upper bed's name will be used for the mergedbed name.

\section{Coal Bed Assessment}

Because a typical surface-mining sequence begins at the ground surface, the following descriptions of coal beds that were assessed in the MTPRB are discussed from youngest to oldest. Summary data for the coal bed thicknesses and depths were derived from statistical summaries based on coal bed digital models. Coal resources are classified according to geologic assurances of existence or reliability (Wood and others, 1983), which are directly dependent on the density of geologic data points. The different reliability categories-measured ( $0.25 \mathrm{mi}$ from point of measurement), indicated $(0.25-0.75$ $\mathrm{mi}$ from point of measurement), inferred (0.75-3.0 mi from point of measurement), and hypothetical (greater than $3.0 \mathrm{mi}$ from point of measurement)-can be established on the basis of distance from a data point (Wood and others, 1983). Coal resource reliability maps were constructed from the digital model for each coal bed assessed.

\section{Roland (Baker) Coal Bed}

The Roland (Baker) is the uppermost coal bed assessed for resource calculations in the MTPRB assessment area. It was identified in 141 drill holes, has a maximum thickness of $14 \mathrm{ft}$, and averages $6 \mathrm{ft}$ thick (fig. 30). The coal bed is present in a small area near the Decker and Spring Creek Mines in the southwestern part of the MTPRB assessment area and correlates to the Roland (Baker) coal bed in the NWPRB assessment area (Scott and others, 2010). Overburden maps for all the beds (depth to top of bed) start at $2.5 \mathrm{ft}$ instead of the normal $0 \mathrm{ft}$, so that the overburden isopach maps match the thickness isopach maps. Depth of the Roland (Baker) ranges from shallow subcrop to about 1,000 ft south of the Decker and Spring Creek Mines. Although limited in extent, more than 92 percent of the available coal resource is at a depth of less than $500 \mathrm{ft}$ (fig. 31, table 8). Coal resource reliability categories for the Roland (Baker) are shown in figure 32. More than 75 percent of the available coal is considered a demonstrated resource, reflecting the overall quantity of data (table 9); approximately 86 percent of this coal is owned by the federal government (table 4).

\section{Smith Coal Bed}

The Smith coal bed, as interpreted from 308 drill holes, has a maximum thickness of $20 \mathrm{ft}$ and averages $6 \mathrm{ft}$ thick (fig. 33). It has about the same areal extent as the Roland (Baker) coal bed in the southwestern part of the MTPRB assessment area and correlates to the Smith coal bed in the NWPRB assessment area (Scott and others, 2010). For this assessment, the Smith, Anderson, Dietz 2, Dietz 3, Canyon, Lower Canyon, Ferry, and Werner/Cook coal beds constitute the Wyodak-Anderson coal 
Table 8. Coal resources and restrictions for 18 beds greater than or equal to 2.5 feet thick, reported in millions of short tons by overburden depth for the Montana Powder River Basin assessment area. Resource includes coal plus partings. Totals may not sum exactly because of rounding.

\begin{tabular}{|c|c|c|c|c|c|c|c|c|c|}
\hline $\begin{array}{l}\text { Coal bed } \\
\text { name }\end{array}$ & $\begin{array}{l}\text { Overburden } \\
\text { thickness } \\
\text { (feet) }\end{array}$ & $\begin{array}{l}\text { Original } \\
\text { resource }\end{array}$ & Burned coal & $\begin{array}{l}\text { Remaining } \\
\text { resource }\end{array}$ & $\begin{array}{l}\text { Previously } \\
\text { mined coal }\end{array}$ & $\begin{array}{l}\text { Land use } \\
\text { restrictions }\end{array}$ & $\begin{array}{l}\text { Technical } \\
\text { restrictions }\end{array}$ & $\begin{array}{l}\text { Available } \\
\text { resource }\end{array}$ & $\begin{array}{c}\text { Percent } \\
\text { of total } \\
\text { remaining }\end{array}$ \\
\hline \multirow{5}{*}{ Roland (Baker) } & $0-500$ & 693 & 12 & 680 & 0 & 0 & 49 & 631 & 92.6 \\
\hline & $500-1,000$ & 2 & 0 & 2 & 0 & 0 & 0 & 2 & 0.3 \\
\hline & $1,000-2,000$ & 0 & 0 & 0 & 0 & 0 & 0 & 0 & 0.0 \\
\hline & $2,000-3,000$ & 0 & 0 & 0 & 0 & 0 & 0 & 0 & 0.0 \\
\hline & Total & 695 & 12 & 682 & $\mathbf{0}$ & $\mathbf{0}$ & 49 & 634 & 92.8 \\
\hline \multirow{5}{*}{ Smith } & $0-500$ & 469 & 7 & 462 & 0 & 2 & 28 & 432 & 83.4 \\
\hline & $500-1,000$ & 970 & 21 & 949 & 0 & 6 & 82 & 861 & 5.3 \\
\hline & $1,000-2,000$ & 375 & 10 & 365 & 0 & 11 & 72 & 283 & 0.0 \\
\hline & $2,000-3,000$ & 2 & 0 & 2 & 0 & 0 & 1 & 0 & 0.0 \\
\hline & Total & 1,817 & 38 & 1,778 & $\mathbf{0}$ & 19 & 183 & 1,577 & 88.7 \\
\hline \multirow{5}{*}{ Anderson } & $0-500$ & 15,463 & 1,455 & 14,009 & 472 & 992 & 104 & 12,440 & 82.8 \\
\hline & $500-1,000$ & 1,018 & 0 & 1,018 & 0 & 0 & 0 & 1,017 & 6.8 \\
\hline & $1,000-2,000$ & 0 & 0 & 0 & 0 & 0 & 0 & 0 & 0.0 \\
\hline & $2,000-3,000$ & 0 & 0 & 0 & 0 & 0 & 0 & 0 & 0.0 \\
\hline & Total & 16,481 & 1,455 & 15,027 & 472 & 992 & 104 & 13,458 & 89.6 \\
\hline \multirow{5}{*}{ Dietz 2} & $0-500$ & 1,356 & 33 & 1,323 & 41 & 10 & 226 & 1,046 & 67.2 \\
\hline & $500-1,000$ & 233 & 0 & 233 & 0 & 0 & 86 & 148 & 9.5 \\
\hline & $1,000-2,000$ & 0 & 0 & 0 & 0 & 0 & 0 & 0 & 0.0 \\
\hline & $2,000-3,000$ & 0 & 0 & 0 & 0 & 0 & 0 & 0 & 0.0 \\
\hline & Total & 1,590 & 33 & 1,556 & 41 & 10 & 311 & 1,194 & 76.7 \\
\hline \multirow{5}{*}{ Dietz 3} & $0-500$ & 8,156 & 759 & 7,397 & 136 & 1,036 & 424 & 5,801 & 66.2 \\
\hline & $500-1,000$ & 1,352 & 0 & 1,352 & 0 & 0 & 82 & 1,270 & 14.5 \\
\hline & $1,000-2,000$ & 8 & 0 & 8 & 0 & 0 & 0 & 8 & 0.1 \\
\hline & $2,000-3,000$ & 0 & 0 & 0 & 0 & 0 & 0 & 0 & 0.0 \\
\hline & Total & 9,516 & 759 & 8,757 & 136 & 1,036 & 506 & 7,079 & 80.8 \\
\hline
\end{tabular}


Table 8. Coal resources and restrictions for 18 beds greater than or equal to 2.5 feet thick, reported in millions of short tons by overburden depth for the Montana Powder River Basin assessment area. Resource includes coal plus partings. Totals may not sum exactly because of rounding.-Continued

\begin{tabular}{|c|c|c|c|c|c|c|c|c|c|}
\hline $\begin{array}{l}\text { Coal bed } \\
\text { name }\end{array}$ & $\begin{array}{l}\text { Overburden } \\
\text { thickness } \\
\text { (feet) }\end{array}$ & $\begin{array}{l}\text { Original } \\
\text { resource }\end{array}$ & Burned coal & $\begin{array}{l}\text { Remaining } \\
\text { resource }\end{array}$ & $\begin{array}{l}\text { Previously } \\
\text { mined coal }\end{array}$ & $\begin{array}{l}\text { Land use } \\
\text { restrictions }\end{array}$ & $\begin{array}{l}\text { Technical } \\
\text { restrictions }\end{array}$ & $\begin{array}{c}\text { Available } \\
\text { resource }\end{array}$ & $\begin{array}{c}\text { Percent } \\
\text { of total } \\
\text { remaining }\end{array}$ \\
\hline \multirow{5}{*}{ Canyon } & $0-500$ & 14,915 & 462 & 14,452 & 0 & 3,189 & 193 & 11,071 & 58.6 \\
\hline & $500-1,000$ & 4,372 & 0 & 4,372 & 0 & 0 & 33 & 4,339 & 23.0 \\
\hline & $1,000-2,000$ & 70 & 0 & 70 & 0 & 0 & 0 & 70 & 0.4 \\
\hline & $2,000-3,000$ & 0 & 0 & 0 & 0 & 0 & 0 & 0 & 0.0 \\
\hline & Total & 19,357 & 462 & 18,895 & $\mathbf{0}$ & 3,189 & 226 & 15,480 & 81.9 \\
\hline \multirow{5}{*}{ Lower Canyon } & $0-500$ & 6,695 & 249 & 6,446 & 0 & 1,875 & 761 & 3,810 & 37.6 \\
\hline & $500-1,000$ & 3,537 & 0 & 3,537 & 0 & 0 & 236 & 3,301 & 32.5 \\
\hline & $1,000-2,000$ & 162 & 0 & 162 & 0 & 0 & 2 & 160 & 1.6 \\
\hline & $2,000-3,000$ & 0 & 0 & 0 & 0 & 0 & 0 & 0 & 0.0 \\
\hline & Total & 10,395 & 249 & 10,146 & $\mathbf{0}$ & 1,875 & 1,000 & 7,272 & 71.7 \\
\hline \multirow{5}{*}{ Ferry } & $0-500 \mathrm{ft}$ & 1,410 & 7 & 1,402 & 0 & 315 & 314 & 773 & 31.5 \\
\hline & $500-1,000$ & 1,051 & 0 & 1,051 & 0 & 0 & 195 & 857 & 34.9 \\
\hline & $1,000-2,000$ & 0 & 0 & 0 & 0 & 0 & 0 & 0 & 0.0 \\
\hline & $2,000-3,000$ & 0 & 0 & 0 & 0 & 0 & 0 & 0 & 0.0 \\
\hline & Total & 2,462 & 7 & 2,454 & $\mathbf{0}$ & 315 & 509 & 1,630 & 66.4 \\
\hline \multirow{5}{*}{ Werner/Cook } & $0-500$ & 14,804 & 762 & 14,041 & 0 & 3,931 & 371 & 9,740 & 39.2 \\
\hline & $500-1,000$ & 10,427 & 0 & 10,427 & 0 & 1 & 210 & 10,216 & 41.1 \\
\hline & $1,000-2,000$ & 376 & 0 & 376 & 0 & 0 & 35 & 341 & 1.4 \\
\hline & $2,000-3,000$ & 0 & 0 & 0 & 0 & 0 & 0 & 0 & 0.0 \\
\hline & Total & 25,606 & 762 & 24,844 & $\mathbf{0}$ & 3,932 & 615 & 20,297 & 81.7 \\
\hline \multirow{5}{*}{ Otter } & $0-500$ & 1,841 & 64 & 1,777 & 0 & 830 & 530 & 417 & 9.5 \\
\hline & $500-1,000$ & 2,387 & 0 & 2,387 & 0 & 5 & 978 & 1,404 & 31.8 \\
\hline & $1,000-2,000$ & 246 & 0 & 246 & 0 & 0 & 141 & 105 & 2.4 \\
\hline & $2,000-3,000$ & 0 & 0 & 0 & 0 & 0 & 0 & 0 & 0.0 \\
\hline & Total & 4,474 & 64 & 4,410 & $\mathbf{0}$ & 835 & 1,649 & 1,926 & 43.7 \\
\hline
\end{tabular}


Table 8. Coal resources and restrictions for 18 beds greater than or equal to 2.5 feet thick, reported in millions of short tons by overburden depth for the

Montana Powder River Basin assessment area. Resource includes coal plus partings. Totals may not sum exactly because of rounding.-Continued

\begin{tabular}{|c|c|c|c|c|c|c|c|c|c|}
\hline $\begin{array}{l}\text { Coal bed } \\
\text { name }\end{array}$ & $\begin{array}{l}\text { Overburden } \\
\text { thickness } \\
\text { (feet) }\end{array}$ & $\begin{array}{l}\text { Original } \\
\text { resource }\end{array}$ & Burned coal & $\begin{array}{c}\text { Remaining } \\
\text { resource }\end{array}$ & $\begin{array}{l}\text { Previously } \\
\text { mined coal }\end{array}$ & $\begin{array}{l}\text { Land use } \\
\text { restrictions }\end{array}$ & $\begin{array}{l}\text { Technical } \\
\text { restrictions }\end{array}$ & $\begin{array}{c}\text { Available } \\
\text { resource }\end{array}$ & $\begin{array}{c}\text { Percent } \\
\text { of total } \\
\text { remaining }\end{array}$ \\
\hline \multirow{5}{*}{ Gates/Wall } & $0-500$ & 3,165 & 121 & 3,045 & 0 & 793 & 651 & 1,601 & 19.7 \\
\hline & $500-1,000$ & 3,769 & 0 & 3,769 & 0 & 9 & 780 & 2,980 & 36.6 \\
\hline & $1,000-2,000$ & 1,323 & 0 & 1,323 & 0 & 0 & 247 & 1,076 & 13.2 \\
\hline & $2,000-3,000$ & 0 & 0 & 0 & 0 & 0 & 0 & 0 & 0.0 \\
\hline & Total & 8,257 & 121 & 8,137 & $\mathbf{0}$ & 802 & 1,678 & 5,656 & 69.5 \\
\hline \multirow{5}{*}{ Pawnee } & $0-500$ & 8,228 & 271 & 7,957 & 0 & 2,481 & 337 & 5,139 & 37.9 \\
\hline & $500-1,000$ & 3,267 & 0 & 3,267 & 0 & 13 & 534 & 2,720 & 20.1 \\
\hline & $1,000-2,000$ & 2,338 & 0 & 2,338 & 0 & 0 & 697 & 1,641 & 12.1 \\
\hline & $2,000-3,000$ & 0 & 0 & 0 & 0 & 0 & 0 & 0 & 0.0 \\
\hline & Total & 13,834 & 271 & 13,563 & $\mathbf{0}$ & 2,494 & 1,568 & 9,501 & 70.1 \\
\hline \multirow{5}{*}{ Odell } & $0-500$ & 1,460 & 26 & 1,434 & 0 & 298 & 845 & 291 & 16.4 \\
\hline & $500-1,000$ & 340 & 0 & 340 & 0 & 0 & 183 & 157 & 8.8 \\
\hline & $1,000-2,000$ & 4 & 0 & 4 & 0 & 0 & 4 & 1 & 0.0 \\
\hline & $2,000-3,000$ & 0 & 0 & 0 & 0 & 0 & 0 & 0 & 0.0 \\
\hline & Total & 1,803 & 26 & 1,778 & $\mathbf{0}$ & 298 & 1,031 & 449 & 25.3 \\
\hline \multirow{5}{*}{ Rosebud/Knobloch } & $0-500$ & 26,169 & 1,743 & 24,425 & 559 & 9,611 & 810 & 13,445 & 32.9 \\
\hline & $500-1,000$ & 12,884 & 0 & 12,884 & 0 & 0 & 428 & 12,456 & 30.5 \\
\hline & $1,000-2,000$ & 3,563 & 0 & 3,563 & 0 & 0 & 306 & 3,257 & 8.0 \\
\hline & $2,000-3,000$ & 0 & 0 & 0 & 0 & 0 & 0 & 0 & 0.0 \\
\hline & Total & 42,616 & 1,743 & 40,873 & 559 & 9,611 & 1,545 & 29,158 & 71.3 \\
\hline \multirow{5}{*}{ McKay/Nance } & $0-500$ & 6,732 & 196 & 6,536 & 68 & 903 & 935 & 4,630 & 44.7 \\
\hline & $500-1,000$ & 2,968 & 0 & 2,968 & 0 & 0 & 658 & 2,310 & 22.3 \\
\hline & $1,000-2,000$ & 849 & 0 & 849 & 0 & 0 & 339 & 510 & 4.9 \\
\hline & $2,000-3,000$ & 0 & 0 & 0 & 0 & 0 & 0 & 0 & 0.0 \\
\hline & Total & 10,549 & 196 & 10,353 & 68 & 903 & 1,932 & 7,450 & 72.0 \\
\hline
\end{tabular}


Table 8. Coal resources and restrictions for 18 beds greater than or equal to 2.5 feet thick, reported in millions of short tons by overburden depth for the Montana Powder River Basin assessment area. Resource includes coal plus partings. Totals may not sum exactly because of rounding.-Continued

\begin{tabular}{|c|c|c|c|c|c|c|c|c|c|}
\hline $\begin{array}{c}\text { Coal bed } \\
\text { name }\end{array}$ & $\begin{array}{c}\text { Overburden } \\
\text { thickness } \\
\text { (feet) }\end{array}$ & $\begin{array}{l}\text { Original } \\
\text { resource }\end{array}$ & Burned coal & $\begin{array}{c}\text { Remaining } \\
\text { resource }\end{array}$ & $\begin{array}{l}\text { Previously } \\
\text { mined coal }\end{array}$ & $\begin{array}{l}\text { Land use } \\
\text { restrictions }\end{array}$ & $\begin{array}{l}\text { Technical } \\
\text { restrictions }\end{array}$ & $\begin{array}{l}\text { Available } \\
\text { resource }\end{array}$ & $\begin{array}{c}\text { Percent } \\
\text { of total } \\
\text { remaining }\end{array}$ \\
\hline \multirow{5}{*}{ Flowers-Goodale } & $0-500$ & 8,315 & 169 & 8,146 & 0 & 553 & 264 & 7,329 & 28.7 \\
\hline & $500-1,000$ & 8,452 & 0 & 8,452 & 0 & 0 & 132 & 8,319 & 32.6 \\
\hline & $1,000-2,000$ & 8,886 & 0 & 8,889 & 0 & 78 & 204 & 9,604 & 33.7 \\
\hline & $2,000-3,000$ & 34 & 0 & 34 & 0 & 0 & 10 & 24 & 0.1 \\
\hline & Total & 25,686 & 169 & 25,518 & $\mathbf{0}$ & 631 & 610 & 24,277 & 95.1 \\
\hline \multirow{5}{*}{ Robinson/Witham } & $0-500$ & 5,261 & 160 & 5,100 & 0 & 4 & 464 & 4,632 & 49.3 \\
\hline & $500-1,000$ & 2,371 & 0 & 2,371 & 0 & 0 & 562 & 1,809 & 19.2 \\
\hline & $1,000-2,000$ & 1,930 & 0 & 1,930 & 0 & 0 & 760 & 1,170 & 12.4 \\
\hline & $2,000-3,000$ & 0 & 0 & 0 & 0 & 0 & 0 & 0 & 0.0 \\
\hline & Total & 9,562 & 160 & 9,402 & $\mathbf{0}$ & 4 & 1,786 & 7,612 & 81.0 \\
\hline \multirow{5}{*}{ Roberts/Terret } & $0-500$ & 3,717 & 128 & 3,589 & 0 & 95 & 914 & 2,580 & 24.6 \\
\hline & $500-1,000$ & 2,135 & 0 & 2,135 & 0 & 0 & 644 & 1,491 & 14.2 \\
\hline & $1,000-2,000$ & 4,285 & 0 & 4,285 & 0 & 0 & 872 & 3,413 & 32.6 \\
\hline & $2,000-3,000$ & 462 & 0 & 462 & 0 & 0 & 25 & 437 & 4.2 \\
\hline & Total & 10,599 & 128 & 10,471 & $\mathbf{0}$ & 95 & 2,455 & 7,921 & 75.6 \\
\hline \multirow{5}{*}{ Total } & $0-500$ & 130,101 & 6,656 & 123,445 & 1,277 & 26,935 & 8,374 & 86,859 & 41.6 \\
\hline & $500-1,000$ & 60,660 & 0 & 60,660 & 0 & 28 & 5,741 & 54,890 & 26.3 \\
\hline & $1,000-2,000$ & 24,042 & 0 & 24,042 & 0 & 78 & 3,606 & 20,358 & 9.8 \\
\hline & $2,000-3,000$ & 497 & 0 & 497 & 0 & 0 & 36 & 461 & 0.2 \\
\hline & Total & 215,300 & 6,656 & 208,644 & 1,277 & 27,042 & 17,757 & 162,568 & 77.9 \\
\hline
\end{tabular}


Table 9. Coal resources and restrictions for 18 beds greater than or equal to 2.5 feet thick, reported in millions of short tons by reliability category for the Montana Powder River Basin assessment area. Resource includes coal plus partings. Reliability categories are based on distance from data point. Measured: less than 0.25 miles; Indicated: $0.25-0.75$ miles; Inferred: $0.75-3.0$ miles; Hypothetical: more than 3.0 miles. Totals may not sum exactly because of rounding:

\begin{tabular}{|c|c|c|c|c|c|c|c|c|c|}
\hline $\begin{array}{l}\text { Coal bed } \\
\text { name }\end{array}$ & $\begin{array}{l}\text { Reliability } \\
\text { category }\end{array}$ & $\begin{array}{l}\text { Original } \\
\text { resource }\end{array}$ & $\begin{array}{c}\text { Burned } \\
\text { coal }\end{array}$ & $\begin{array}{l}\text { Remaining } \\
\text { resource }\end{array}$ & $\begin{array}{l}\text { Previously } \\
\text { mined coal }\end{array}$ & $\begin{array}{l}\text { Land use } \\
\text { restrictions }\end{array}$ & $\begin{array}{l}\text { Technical } \\
\text { restrictions }\end{array}$ & $\begin{array}{l}\text { Available } \\
\text { resource }\end{array}$ & $\begin{array}{c}\text { Percent } \\
\text { of total } \\
\text { remaining }\end{array}$ \\
\hline \multirow{5}{*}{ Roland (Baker) } & Measured & 166 & 3 & 163 & 0 & 0 & 7 & 156 & 22.9 \\
\hline & Indicated & 353 & 7 & 346 & 0 & 0 & 20 & 325 & 47.7 \\
\hline & Inferred & 174 & 2 & 173 & 0 & 0 & 21 & 151 & 22.2 \\
\hline & Hypothetical & 1 & 1 & 1 & 0 & 0 & 0 & 1 & 0.1 \\
\hline & Total & 695 & 12 & 682 & $\mathbf{0}$ & $\mathbf{0}$ & 49 & 634 & 92.8 \\
\hline \multirow{5}{*}{ Smith } & Measured & 469 & 7 & 462 & 0 & 2 & 28 & 432 & 24.3 \\
\hline & Indicated & 971 & 21 & 949 & 0 & 6 & 82 & 861 & 48.4 \\
\hline & Inferred & 375 & 10 & 365 & 0 & 11 & 72 & 283 & 15.9 \\
\hline & Hypothetical & 2 & 0 & 2 & 0 & 0 & 1 & 0 & 0.0 \\
\hline & Total & 1,817 & 38 & 1,778 & $\mathbf{0}$ & 19 & 183 & 1,577 & 88.7 \\
\hline \multirow{5}{*}{ Anderson } & Measured & 3,855 & 164 & 3,692 & 402 & 167 & 6 & 3,117 & 20.7 \\
\hline & Indicated & 7,608 & 611 & 6,997 & 70 & 252 & 25 & 6,651 & 44.3 \\
\hline & Inferred & 4,916 & 651 & 4,265 & 0 & 530 & 51 & 3,683 & 24.5 \\
\hline & Hypothetical & 102 & 29 & 73 & 0 & 43 & 22 & 7 & 0.0 \\
\hline & Total & 16,481 & 1,455 & 15,027 & 472 & 992 & 104 & 13,458 & 89.6 \\
\hline \multirow{5}{*}{ Dietz 2} & Measured & 682 & 13 & 669 & 40 & 8 & 59 & 561 & 36.0 \\
\hline & Indicated & 671 & 13 & 658 & 1 & 2 & 182 & 474 & 30.4 \\
\hline & Inferred & 225 & 6 & 218 & 0 & 0 & 61 & 158 & 10.1 \\
\hline & Hypothetical & 12 & 0 & 12 & 0 & 0 & 10 & 2 & 0.1 \\
\hline & Total & 1,590 & 33 & 1,556 & 41 & 10 & 311 & 1,194 & 76.7 \\
\hline \multirow{5}{*}{ Dietz 3} & Measured & 2,003 & 116 & 1,887 & 96 & 64 & 50 & 1,678 & 19.2 \\
\hline & Indicated & 4,710 & 332 & 4,378 & 38 & 295 & 196 & 3,849 & 44.0 \\
\hline & Inferred & 2,732 & 306 & 2,426 & 3 & 633 & 247 & 1,543 & 17.6 \\
\hline & Hypothetical & 71 & 6 & 65 & 0 & 44 & 12 & 9 & 0.1 \\
\hline & Total & 9,516 & 759 & 8,757 & 136 & 1,036 & 506 & 7,079 & 80.8 \\
\hline
\end{tabular}


Table 9. Coal resources and restrictions for 18 beds greater than or equal to 2.5 feet thick, reported in millions of short tons by reliability category for the Montana Powder River Basin assessment area. Resource includes coal plus partings. Reliability categories are based on distance from data point. Measured: less than 0.25 miles; Indicated: $0.25-0.75$ miles; Inferred: $0.75-3.0$ miles; Hypothetical: more than 3.0 miles. Totals may not sum exactly because of rounding.-Continued

\begin{tabular}{|c|c|c|c|c|c|c|c|c|c|}
\hline $\begin{array}{l}\text { Coal bed } \\
\text { name }\end{array}$ & $\begin{array}{c}\text { Reliability } \\
\text { category }\end{array}$ & $\begin{array}{c}\text { Original } \\
\text { resource }\end{array}$ & $\begin{array}{c}\text { Burned } \\
\text { coal }\end{array}$ & $\begin{array}{l}\text { Remaining } \\
\text { resource }\end{array}$ & $\begin{array}{l}\text { Previously } \\
\text { mined coal }\end{array}$ & $\begin{array}{l}\text { Land use } \\
\text { restrictions }\end{array}$ & $\begin{array}{c}\text { Technical } \\
\text { restrictions }\end{array}$ & $\begin{array}{c}\text { Available } \\
\text { resource }\end{array}$ & $\begin{array}{c}\text { Percent } \\
\text { of total } \\
\text { remaining }\end{array}$ \\
\hline \multirow{5}{*}{ Canyon } & Measured & 2,408 & 22 & 2,385 & 0 & 140 & 17 & 2,229 & 11.8 \\
\hline & Indicated & 7,841 & 148 & 7,693 & 0 & 664 & 77 & 6,951 & 36.8 \\
\hline & Inferred & 8,689 & 272 & 8,417 & 0 & 2,045 & 117 & 6,256 & 33.1 \\
\hline & Hypothetical & 420 & 20 & 400 & 0 & 340 & 15 & 45 & 0.2 \\
\hline & Total & 19,357 & 462 & 18,895 & $\mathbf{0}$ & 3,189 & 226 & 15,480 & 81.9 \\
\hline \multirow{5}{*}{ Lower Canyon } & Measured & 1,211 & 4 & 1,208 & 0 & 99 & 42 & 1,067 & 10.5 \\
\hline & Indicated & 3,805 & 29 & 3,776 & 0 & 519 & 259 & 2,998 & 29.5 \\
\hline & Inferred & 4,883 & 173 & 4,710 & 0 & 1,063 & 644 & 3,003 & 29.6 \\
\hline & Hypothetical & 496 & 43 & 453 & 0 & 194 & 55 & 204 & 2.0 \\
\hline & Total & 10,395 & 249 & 10,146 & $\mathbf{0}$ & 1,875 & 1,000 & 7,272 & 71.7 \\
\hline \multirow{5}{*}{ Ferry } & Measured & 194 & 0 & 194 & 0 & 9 & 39 & 146 & 5.9 \\
\hline & Indicated & 714 & 2 & 712 & 0 & 57 & 156 & 499 & 20.3 \\
\hline & Inferred & 1,510 & 4 & 1,506 & 0 & 243 & 277 & 985 & 40.2 \\
\hline & Hypothetical & 44 & 0 & 43 & 0 & 6 & 37 & 0 & 0.0 \\
\hline & Total & 2,462 & 7 & 2,454 & $\mathbf{0}$ & 315 & 509 & 1,630 & 66.4 \\
\hline \multirow{5}{*}{ Werner/Cook } & Measured & 1,874 & 35 & 1,839 & 0 & 110 & 23 & 1,707 & 6.9 \\
\hline & Indicated & 8,747 & 188 & 8,559 & 0 & 716 & 132 & 7,710 & 31.0 \\
\hline & Inferred & 14,364 & 505 & 13,860 & 0 & 2,724 & 437 & 10,699 & 43.1 \\
\hline & Hypothetical & 621 & 35 & 586 & 0 & 382 & 24 & 180 & 0.7 \\
\hline & Total & 25,606 & 762 & 24,844 & $\mathbf{0}$ & 3,932 & 615 & 20,297 & 81.7 \\
\hline \multirow{5}{*}{ Otter } & Measured & 391 & 2 & 388 & 0 & 39 & 99 & 251 & 5.7 \\
\hline & Indicated & 1,428 & 19 & 1,409 & 0 & 187 & 433 & 789 & 17.9 \\
\hline & Inferred & 2,578 & 40 & 2,538 & 0 & 586 & 1,067 & 884 & 20.1 \\
\hline & Hypothetical & 77 & 2 & 75 & 0 & 23 & 50 & 2 & 0.0 \\
\hline & Total & 4,474 & 64 & 4,410 & $\mathbf{0}$ & 835 & 1,649 & 1,926 & 43.7 \\
\hline
\end{tabular}


Table 9. Coal resources and restrictions for 18 beds greater than or equal to 2.5 feet thick, reported in millions of short tons by reliability category for the Montana Powder River Basin assessment area. Resource includes coal plus partings. Reliability categories are based on distance from data point. Measured: less than 0.25 miles; Indicated: $0.25-0.75$ miles; Inferred: $0.75-3.0$ miles; Hypothetical: more than 3.0 miles. Totals may not sum exactly because of rounding.-Continued

\begin{tabular}{|c|c|c|c|c|c|c|c|c|c|}
\hline $\begin{array}{l}\text { Coal bed } \\
\text { name }\end{array}$ & $\begin{array}{c}\text { Reliability } \\
\text { category }\end{array}$ & $\begin{array}{l}\text { Original } \\
\text { resource }\end{array}$ & $\begin{array}{l}\text { Burned } \\
\text { coal }\end{array}$ & $\begin{array}{l}\text { Remaining } \\
\text { resource }\end{array}$ & $\begin{array}{l}\text { Previously } \\
\text { mined coal }\end{array}$ & $\begin{array}{l}\text { Land use } \\
\text { restrictions }\end{array}$ & $\begin{array}{l}\text { Technical } \\
\text { restrictions }\end{array}$ & $\begin{array}{l}\text { Available } \\
\text { resource }\end{array}$ & $\begin{array}{l}\text { Percent } \\
\text { of total } \\
\text { remaining }\end{array}$ \\
\hline \multirow{5}{*}{ Gates/Wall } & Measured & 374 & 4 & 370 & 0 & 46 & 53 & 271 & 3.3 \\
\hline & Indicated & 2,126 & 32 & 2,094 & 0 & 221 & 314 & 1,559 & 19.2 \\
\hline & Inferred & 5,576 & 81 & 5,495 & 0 & 502 & 1,169 & 3,824 & 47.0 \\
\hline & Hypothetical & 181 & 4 & 177 & 0 & 33 & 142 & 2 & 0.0 \\
\hline & Total & 8,257 & 121 & 8,136 & $\mathbf{0}$ & 802 & 1,678 & 5,656 & 69.5 \\
\hline \multirow{5}{*}{ Pawnee } & Measured & 607 & 8 & 599 & 0 & 57 & 52 & 489 & 3.6 \\
\hline & Indicated & 3,433 & 66 & 3,367 & 0 & 354 & 302 & 2,711 & 20.0 \\
\hline & Inferred & 9,310 & 182 & 9,128 & 0 & 1,855 & 1,167 & 6,105 & 45.0 \\
\hline & Hypothetical & 483 & 14 & 469 & 0 & 227 & 46 & 196 & 1.4 \\
\hline & Total & 13,834 & 271 & 13,563 & $\mathbf{0}$ & 2,494 & 1,568 & 9,501 & 70.1 \\
\hline \multirow{5}{*}{ Odell } & Measured & 92 & 1 & 92 & 0 & 13 & 43 & 36 & 2.0 \\
\hline & Indicated & 473 & 8 & 465 & 0 & 82 & 231 & 152 & 8.6 \\
\hline & Inferred & 1,193 & 16 & 1,178 & 0 & 203 & 713 & 261 & 14.7 \\
\hline & Hypothetical & 44 & 0 & 44 & 0 & 0 & 44 & 0 & 0.0 \\
\hline & Total & 1,803 & 26 & 1,778 & $\mathbf{0}$ & 298 & 1,031 & 449 & 25.3 \\
\hline \multirow{5}{*}{ Rosebud/Knobloch } & Measured & 4,691 & 175 & 4,516 & 489 & 602 & 58 & 3,367 & 8.2 \\
\hline & Indicated & 12,056 & 780 & 11,276 & 66 & 2,905 & 328 & 7,977 & 19.5 \\
\hline & Inferred & 24,661 & 678 & 23,984 & 4 & 5,996 & 1,033 & 16,950 & 41.5 \\
\hline & Hypothetical & 1,207 & 111 & 1,097 & 0 & 107 & 126 & 864 & 2.1 \\
\hline & Total & 42,616 & 1,743 & 40,873 & 559 & 9,611 & 1,545 & 29,158 & 71.3 \\
\hline \multirow{5}{*}{ McKay/Nance } & Measured & 1,841 & 52 & 1,790 & 68 & 55 & 94 & 1,573 & 15.2 \\
\hline & Indicated & 3,288 & 69 & 3,218 & 0 & 270 & 450 & 2,498 & 24.1 \\
\hline & Inferred & 5,268 & 50 & 5,218 & 0 & 578 & 1,350 & 3,291 & 31.8 \\
\hline & Hypothetical & 152 & 26 & 127 & 0 & 1 & 37 & 89 & 0.9 \\
\hline & Total & 10,549 & 196 & 10,353 & 68 & 903 & 1,932 & 7,450 & 72.0 \\
\hline
\end{tabular}


Table 9. Coal resources and restrictions for 18 beds greater than or equal to 2.5 feet thick, reported in millions of short tons by reliability category for the Montana Powder River Basin assessment area. Resource includes coal plus partings. Reliability categories are based on distance from data point. Measured: less than 0.25 miles; Indicated: $0.25-0.75$ miles; Inferred: $0.75-3.0$ miles; Hypothetical: more than 3.0 miles. Totals may not sum exactly because of rounding.-Continued

\begin{tabular}{|c|c|c|c|c|c|c|c|c|c|}
\hline $\begin{array}{l}\text { Coal bed } \\
\text { name }\end{array}$ & $\begin{array}{c}\text { Reliability } \\
\text { category }\end{array}$ & $\begin{array}{l}\text { Original } \\
\text { resource }\end{array}$ & $\begin{array}{c}\text { Burned } \\
\text { coal }\end{array}$ & $\begin{array}{l}\text { Remaining } \\
\text { resource }\end{array}$ & $\begin{array}{l}\text { Previously } \\
\text { mined coal }\end{array}$ & $\begin{array}{l}\text { Land use } \\
\text { restrictions }\end{array}$ & $\begin{array}{l}\text { Technical } \\
\text { restrictions }\end{array}$ & $\begin{array}{l}\text { Available } \\
\text { resource }\end{array}$ & $\begin{array}{c}\text { Percent } \\
\text { of total } \\
\text { remaining }\end{array}$ \\
\hline \multirow{5}{*}{ Flowers-Goodale } & Measured & 812 & 6 & 806 & 0 & 20 & 11 & 774 & 3.0 \\
\hline & Indicated & 4,922 & 38 & 4,884 & 0 & 177 & 67 & 4,640 & 18.2 \\
\hline & Inferred & 18,449 & 121 & 18,328 & 0 & 432 & 455 & 17,441 & 68.3 \\
\hline & Hypothetical & 1,504 & 4 & 1,500 & 0 & 2 & 77 & 1,421 & 5.6 \\
\hline & Total & 25,686 & 169 & 25,518 & $\mathbf{0}$ & 631 & 610 & 24,277 & 95.1 \\
\hline \multirow{5}{*}{ Robinson/Witham } & Measured & 1,842 & 78 & 1,764 & 0 & 2 & 74 & 1,688 & 18.0 \\
\hline & Indicated & 2,615 & 66 & 2,549 & 0 & 0 & 385 & 2,164 & 23.0 \\
\hline & Inferred & 4,898 & 16 & 4,882 & 0 & 2 & 1,240 & 3,640 & 38.7 \\
\hline & Hypothetical & 208 & 0 & 208 & 0 & 0 & 87 & 120 & 1.3 \\
\hline & Total & 9,562 & 160 & 9,402 & $\mathbf{0}$ & 4 & 1,786 & 7,612 & 81.0 \\
\hline \multirow{5}{*}{ Roberts/Terret } & Measured & 384 & 4 & 380 & 0 & 3 & 54 & 323 & 3.1 \\
\hline & Indicated & 2,081 & 23 & 2,059 & 0 & 17 & 338 & 1,703 & 16.3 \\
\hline & Inferred & 7,287 & 74 & 7,213 & 0 & 74 & 1,778 & 5,361 & 51.2 \\
\hline & Hypothetical & 847 & 27 & 819 & 0 & 2 & 285 & 533 & 5.1 \\
\hline & Total & 10,599 & 128 & 10,471 & $\mathbf{0}$ & 95 & 2,455 & 7,921 & 75.6 \\
\hline \multirow{5}{*}{ Total } & Measured & 23,899 & 695 & 23,203 & 1,096 & 1,436 & 807 & 19,864 & 9.5 \\
\hline & Indicated & 67,842 & 2,453 & 65,389 & 174 & 6,725 & 3,980 & 54,511 & 26.1 \\
\hline & Inferred & 117,088 & 3,184 & 113,903 & 7 & 17,477 & 11,901 & 84,518 & 40.5 \\
\hline & Hypothetical & 6,472 & 323 & 6,149 & 0 & 1,404 & 1,069 & 3,676 & 1.8 \\
\hline & Total & 215,300 & 6,656 & 208,644 & 1,277 & 27,042 & 17,757 & 162,568 & 77.9 \\
\hline
\end{tabular}


zone described in both the Gillette coal field report (Luppens and others, 2008) and the NWPRB assessment area report (Scott and others, 2010) (fig. 19). Depth of the Smith ranges from shallow subcrop to about 1,000 ft south of the Decker and Spring Creek Mines; more than 83 percent of the available coal resource is at a depth of less than 500 (fig. 34, table 8). Coal resource reliability categories for the Smith bed are shown in figure 35 . More than 72 percent of the available coal is considered a demonstrated resource reflecting the overall quantity of data (table 9); most of the available coal resource is owned by the Federal government (83 percent) (table 4).

\section{Anderson Coal Bed}

Identified in 851 drill holes, the Anderson coal bed has a maximum thickness of $93 \mathrm{ft}$ near the Decker and Spring Creek Mine areas (fig. 36). The coal bed averages $22 \mathrm{ft}$ thick and correlates with the Anderson coal bed in the NWPRB assessment area (Scott and others, 2010) and also the Anderson coal bed of Roberts and others (1999c). The coal is present in a large area in the southwestern part of the MTPRB assessment area (fig. 36). The Anderson, along with the Dietz 2 and Dietz 3 coal beds, is presently mined at the Decker and Spring Creek Mines. Depth of the Anderson ranges from shallow subcrop to about 1,000 ft near the Decker and Spring Creek Mines; more than 82 percent of the available coal resource is at a depth of less than $500 \mathrm{ft}$ (fig. 37, table 8). About 65 percent of the available coal is considered a demonstrated resource reflecting the overall quantity of data (table 9). The coal reliability map is shown in figure 38; approximately 83 percent of the available coal resource is owned by the federal government (table 4).

\section{Dietz 2 Coal Bed}

The Dietz 2 coal bed was identified in 443 drill holes, has a maximum thickness of $32 \mathrm{ft}$, and averages $6 \mathrm{ft}$ thick (fig. 39). It is present in a small area in the southwestern part of MTPRB assessment area and correlates to the Dietz 2 coal bed in the NWPRB assessment area (Scott and others, 2010) and also the Dietz 2 coal bed of Roberts and others (1999c). Depth of the Dietz 2 ranges from shallow subcrop to about 1,000 ft near the Decker and Spring Creek Mine areas; approximately 67 percent of the available coal resource is at a depth of less than $500 \mathrm{ft}$ (fig. 40, table 8). Coal resource reliability categories for the Dietz 2 are shown in figure 41. More than 66 percent of the available coal is considered a demonstrated resource reflecting the overall quantity of data (table 9); most of the available coal resource (68 percent) is owned by the federal government (table 4).

\section{Dietz 3 Coal Bed}

The Dietz 3 coal bed, as interpreted from 741 drill holes, has a maximum thickness of $59 \mathrm{ft}$ and an average thickness of $11 \mathrm{ft}$ (fig. 42). The coal bed is present in two separate areas near the Decker and Spring Creek Mines where it exceeds a thickness of over $40 \mathrm{ft}$. The Dietz 3 bed correlates with the Dietz 3 in the NWPRB assessment area (Scott and others, 2010) and the Dietz 3 coal bed of Roberts and others (1999c). Depth ranges from shallow subcrop to about 1,000 ft near the Decker and Spring Creek Mines. Approximately 66 percent of the available coal resource is at a depth of less than 500 $\mathrm{ft}$ (fig. 43, table 8). About 63 percent of the available coal is considered a demonstrated resource reflecting the overall quantity of data (fig. 44; table 9); more than 72 percent of the available coal resource is owned by the Federal government (table 4).

\section{Canyon Coal Bed}

Originally named the Monarch coal bed by Taff (1909), this coal bed is equivalent to the Canyon coal bed of Baker (1929) (Law and others, 1979). Since that time it has been referred to as both the Canyon and the Monarch. The Canyon coal bed name is used in this report as it correlates to the Canyon coal bed in the NWPRB assessment area (Scott and others, 2010). This coal bed also correlates with the Canyon coal bed of Roberts and others (1999c). The coal bed is present in a large area within the southwestern part of the MTPRB assessment area (fig. 45). Canyon coal was identified in 762 drill holes and reaches a maximum thickness of $57 \mathrm{ft}$; average thickness is $14 \mathrm{ft}$ (fig. 45). Depth ranges from shallow subcrop to about $1,500 \mathrm{ft}$ near the Decker and Spring Creek Mines; more than 58 percent of the available coal resource is at a depth of less than $500 \mathrm{ft}$ (fig. 46, table 8). About 48 percent of the available coal is considered a demonstrated resource reflecting the overall quantity of data (table 9). The coal resource reliability map for the Canyon bed is shown in figure 47; about 75 percent of the available coal resource is owned by the Federal government (table 4).

\section{Lower Canyon Coal Bed}

The Lower Canyon coal bed, a lower split of the Canyon coal bed, was identified in 533 drill holes, has a maximum thickness of $42 \mathrm{ft}$, and averages $8 \mathrm{ft}$ thick (fig. 48). It is present in a large area in the Decker and Spring Creek Mines in the southwestern part of the assessment area. This bed correlates to the Lower Canyon coal bed in the NWPRB assessment area (Scott and others, 2010) and also to the Lower Canyon of Roberts and others (1999c). Depth ranges from shallow subcrop to about 1,500 ft near the Decker and Spring Creek Mine areas; more than 37 percent of the available coal resource is at a depth of less than $500 \mathrm{ft}$ (fig. 49, table 8).

About 40 percent of the available coal is considered a demonstrated resource (table 9); the coal resource reliability map for the Lower Canyon bed is shown in figure 50; more than 65 percent of the available coal resource is owned by the Federal government (table 4). 


\section{Ferry Coal Bed}

The Ferry coal bed was identified in 169 drill holes and is limited in areal extent to the southwestern part of the MTPRB assessment area. The bed has a maximum thickness of $15 \mathrm{ft}$ and an average thickness of $6 \mathrm{ft}$ (fig. 51). Depth ranges from shallow subcrop to about 1,500 ft near the Spring Creek Mine; about 31 percent of the available coal resource is at a depth of less than $500 \mathrm{ft}$ (fig. 52, table 8). This coal bed correlates with the Ferry coal bed in the NWPRB assessment area (Scott and others, 2010). Only about 25 percent of the available coal is considered a demonstrated resource (table 9). The coal resource reliability map for the Ferry bed is shown in figure 53; about 58 percent of the available coal resource is owned by the Federal government (table 4).

\section{Werner/Cook Coal Bed}

The Werner/Cook coal bed, identified in 508 drill holes, has a maximum thickness of $62 \mathrm{ft}$ and averages $15 \mathrm{ft}$ (fig. 54). This is the oldest coal bed in the Wyodak-Anderson coal zone. It correlates with the Werner coal bed in the NWPRB assessment area of Scott and others (2010). The coal bed is present near the Decker and Spring Creek Mines, where it exceeds a thickness of $60 \mathrm{ft}$. Depth ranges from shallow subcrop to over $1,500 \mathrm{ft}$ near the Spring Creek Mine; about 39 percent of the available coal resource is at a depth of less than $500 \mathrm{ft}$ (fig. 55, table 8). More than 37 percent of the available coal is considered a demonstrated resource (table 9). The coal resource reliability map for the Werner/Cook bed is shown in figure 56; about 74 percent of the available coal resource is owned by the federal government (table 4).

\section{Otter Coal Bed}

Distribution of the Otter coal bed is shown in figure 57. Based on 315 drill holes, it reaches a maximum thickness of $32 \mathrm{ft}$ and has an average thickness of $4 \mathrm{ft}$ (fig. 57). The Otter coal bed correlates with the Otter coal bed in the NWPRB assessment area (Scott and others, 2010). Areas of greatest thickness are near the Decker and Spring Creek Mine areas in the southwestern part of the MTPRB assessment area. Depth ranges from shallow subcrop to over 1,500 ft near the Spring Creek Mine; about 9 percent of the available coal resource is at a depth less than $500 \mathrm{ft}$ (fig. 58, table 8). About 24 percent of the available coal is considered a demonstrated resource (table 9). The coal resource reliability map for the Otter bed is shown in figure 59; about 40 percent of the available coal resource is owned by the federal government (table 4).

\section{Gates/Wall Coal Bed}

Known as the Wall coal bed in Montana and as the Gates coal bed in Wyoming, this bed is present in a large area in the southwestern part of the MTPRB assessment area (fig. 60). It correlates with the Gates coal bed in the NWPRB assessment area (Scott and others, 2010). Identified in 244 drill holes, the coal has a maximum thickness of $23 \mathrm{ft}$ and averages $5 \mathrm{ft}$ thick (fig. 60). Depth ranges from shallow subcrop to about 2,000 ft in the Spring Creek Mine area; about 19 percent of the available coal resource is at a depth of less than $500 \mathrm{ft}$ (fig. 61, table 8). About 22 percent of the available coal is considered a demonstrated resource (table 9). The coal resource reliability map for the Gates/Wall bed is shown in figure 62; about 62 percent of the available coal resource is owned by the Federal government (table 4).

\section{Pawnee Coal Bed}

The Pawnee coal bed has a large areal extent in the southern part of the MTPRB assessment area. The coal bed was identified in 278 drill holes, has a maximum thickness of $34 \mathrm{ft}$ and averages $8 \mathrm{ft}$ (fig. 63). Depth ranges from shallow subcrop to about 2,000 ft in the Spring Creek Mine area; about 37 percent of the available coal resource is at a depth of less than $500 \mathrm{ft}$ (fig. 64, table 8). The coal bed correlates with the Pawnee coal bed in the NWPRB assessment area (Scott and others, 2010). More than 23 percent of the available coal is considered a demonstrated resource (table 9). The coal resource reliability map for the Pawnee coal bed is shown in figure 65; about 62 percent of the available coal resource is owned by the Federal government (table 4).

\section{Odell Coal Bed}

The Odell coal bed is present in a small area in the southcentral part of the MTPRB assessment area. The coal bed was identified in 117 drill holes, has a maximum thickness of $14 \mathrm{ft}$, and averages $3 \mathrm{ft}$ (fig. 66). Depth ranges from shallow subcrop to about 2,000 ft in the south-central part of the assessment area; about 16 percent of the available coal is at a depth of less than $500 \mathrm{ft}$ (fig. 67, table 8). The Odell coal bed correlates with the Odell coal bed in the NWPRB assessment area (Scott and others, 2010). Only about 10 percent of the available coal is considered a demonstrated resource (table 9). The coal resource reliability map for the Odell coal bed is shown in figure 68; about 22 percent of the available coal resource is owned by the Federal government (table 4).

\section{Rosebud/Knobloch Coal Bed}

The Rosebud/Knobloch coal bed is known as the Rosebud coal bed west of Rosebud Creek and as the Knobloch east of Rosebud Creek (fig. 69); it is one of the most significant coal beds in the MTPRB assessment area. Identified in 4,168 drill holes, this coal is mined in the Rosebud, Absaloka, and Big Sky Mine areas where it has a maximum thickness of $72 \mathrm{ft}$ and averages $15 \mathrm{ft}$ thick (fig. 69). Some of the thickest coal is under the Custer National Forest (fig. 69). The Rosebud/Knobloch coal bed correlates to the Rosebud coal bed of Roberts 
and others (1999c). Depth ranges from shallow subcrop to about 2,000 ft along the south-central part of the assessment area; about 33 percent of the available coal resource is at a depth of less than $500 \mathrm{ft}$ with an additional 30 percent between 500-1,000 ft deep (fig. 70, table 8). The Rosebud/Knobloch coal bed is presently mined at both the Absaloka and Rosebud Mines. Approximately 27 percent of the available coal is considered a demonstrated resource (table 9). The coal resource reliability map for the Rosebud/Knobloch coal bed is shown in figure 71; about 50 percent of the available coal resource is owned by the Federal government (table 4).

\section{McKay/Nance Coal Bed}

The McKay/Nance coal bed, known as the McKay coal bed west of Rosebud Creek and as the Nance east of Rosebud Creek, is present in the Rosebud, Absaloka, and Big Sky Mine areas (fig. 72) and merges into the Rosebud/Knobloch coal bed east of Ashland. This merging contributes to the greater thickness of the Rosebud/Knobloch in that area. As identified in 1,697 drill holes, maximum thickness is $30 \mathrm{ft}$ and average thickness is $9 \mathrm{ft}$ (fig. 72). It correlates with the McKay coal bed of Roberts and others (1999c). Because of a topographic high (Little Wolf Mountains), depth to the coal bed ranges from shallow subcrop to over 2,000 ft between the Absaloka and Big Sky Mines. About 44 percent of the available coal resource is at a depth of less than $500 \mathrm{ft}$, with an additional 22 percent at a depth of 500-1,000 ft (fig. 73, table 8). Approximately 39 percent of the available coal is considered a demonstrated resource (table 9). The coal resource reliability map for the McKay/Nance coal bed is shown in figure 74; about 43 percent of the available coal resource is owned by the Federal government (table 4).

\section{Flowers-Goodale Coal Bed}

Identified in 365 drill holes, the Flowers-Goodale coal bed underlies a large area in the southern half of the assessment area. Maximum thickness is $35 \mathrm{ft}$, and average thickness is $9 \mathrm{ft}$ (fig. 75). Depth ranges from shallow subcrop to about 2,500 $\mathrm{ft}$ in the southwestern part of the assessment area; about 28 percent of the available coal resource is at a depth of less than $500 \mathrm{ft}$, with an additional 32 percent at a depth of 500-1,000 ft deep (fig. 76, table 8). Approximately 21 percent of the available coal is considered a demonstrated resource (table 9). The coal resource reliability map for the FlowersGoodale coal bed is shown in figure 77; about 77 percent of the available coal resource is owned by the Federal government (table 4).

\section{Robinson/Witham Coal Bed}

The Robinson/Witham coal bed is known as the Robinson coal bed west of Rosebud Creek and as the Witham coal bed east of Rosebud Creek (fig. 78). The coal bed, identified in
646 drill holes, has a maximum thickness of $37 \mathrm{ft}$ and averages $6 \mathrm{ft}$ thick (fig. 78). The coal is also in a large area in the southcentral part of the MTPRB assessment area. The Robinson/ Witham correlates with the Robinson of Roberts and others (1999c). Because of a topographic high (Little Wolf Mountains), depth to the coal bed ranges from shallow subcrop to over 2,000 ft between the Absaloka and Big Sky Mines. About 49 percent of the available coal resource is at a depth of less than $500 \mathrm{ft}$ with an additional 19 percent at a depth of $500-1,000 \mathrm{ft}$ deep (fig. 79, table 8). Approximately 41 percent of the available coal is considered a demonstrated resource (table 9). The coal resource reliability map for the Robinson/ Witham coal bed is shown in figure 80; about 38 percent of the available coal resource is owned by the Federal government (table 4).

\section{Roberts/Terret Coal Bed}

Identified in 217 drill holes, the Roberts/Terret coal bed is present throughout much of the central part of the assessment area. This bed correlates with the Roberts coal bed in the NWPRB assessment area of Scott and other (2010), maximum thickness is $28 \mathrm{ft}$ and average thickness is $5 \mathrm{ft}$ (fig. 81). Depth of the Roberts/Terret coal bed ranges from shallow subcrop to over 2,500 ft; about 24 percent of the available coal resource is at a depth of less than $500 \mathrm{ft}$ (fig. 82, table 8). Approximately 19 percent of the available coal is considered a demonstrated resource (table 9). The coal resource reliability map for the Roberts/Terret bed is shown in figure 83; about 57 percent of the available coal resource is owned by the Federal government (table 4).

\section{Assessment of Resources and Reserves}

This assessment represents the most thorough evaluation of coal resources within the MTPRB assessment area in terms of both the number of data points interpreted and coal beds assessed. As a consequence, the total amount of coal resources assigned to the hypothetical reliability category is only about 2 percent (table 9).

In summary, a total of 26 coal beds, all in the Fort Union Formation were included in this assessment, 18 of which were modeled and evaluated to determine in-place coal resources (fig. 29). With no restrictions applied, the total original resource for these 18 beds was calculated to be about 215 BST. Available coal resources, which are part of the original coal resource remaining after subtracting restrictions and areas of burned coal, were then calculated. Restrictions included railroads, federal interstate highways, urban areas, alluvial valley floors, state parks, national forests, and mined-out areas.

Figure 84 provides amount and percent of original coal resources by individual beds. Tables 4,8 , and 9 provide resource summaries based on ownership, overburden 
thickness, and reliability categories. About 7 BST ( 3 percent) of the total original coal resource was estimated to be burned (clinker) along the outcrop in the MTPRB, leaving a resource of 208 BST. Approximately 46 BST (22 percent) of the original resource is affected by restrictions (previously mined, too thin, land use, and technical). Subtraction of these restrictions from the 208 BST leaves about 162 BST (78 percent) of the original resource available for potential development in the MTPRB (tables 4, 8, 9).

\section{Surface Coal Resource Results}

Strip ratio maps were derived from overburden isopach maps of the 18 assessed beds. As displayed in the overburden maps of the Anderson, Dietz 2, and Dietz 3 (figs. 37, 40, 43), as well as the overburden map of the Rosebud/Knobloch (fig. 70), the areas of least overburden thickness are near active coal mines. About 42 percent ( $87 \mathrm{BST}$ ) of the original resource is less than $500 \mathrm{ft}$ deep; about 26 percent (55 BST) is between 500 - and 1,000-ft depths; and about 10 percent (21 BST) is deeper than 2,000 ft (table 8). Coal resource reliability categories for the 18 beds are summarized in table 9 . About 76 percent (159 BST) of the total original resources can be classified as measured, indicated or inferred, reflecting the overall substantial improvement in reliability confidence provided by the additional data included in this assessment. Coal ownership for the 18 beds is summarized in table 4 . The majority of available coal resources, 132 BST (64 percent of the original), are owned by the federal government (table 4). Only about 4 percent ( 315 MST) is owned by the State of Montana, and about 11 percent (22 BST) is owned by private entities (table 4).

It was determined that 10 of the 18 coal beds had sufficient areal extent and thickness to be further evaluated for recoverable resources. These are the Roland (Baker), Smith, Anderson, Dietz 2, Dietz 3, Canyon, Werner/Cook, Pawnee, Rosebud/Knobloch, and Flowers-Goodale, with a calculated total of $151 \mathrm{BST}$ of the $162 \mathrm{BST}$ of available resource (table 3). At a strip ratio of 10:1 or less, 39 BST remained of this total (table 2), and after mining and processing losses were also subtracted, only about 35 BST of coal were considered as a recoverable resource (table 2).

\section{Surface Coal Reserve Results}

The third and final phase in the assessment of the MTPRB was the economic evaluation of recoverable resources for the 10 coal beds listed above. Economically recoverable resources (reserves) were determined through economic analysis (see Appendix for detailed discussion of surface-mine models and assumptions). The present value of all mining expenditures over a project life at a rate of return $(R O R)$ on investment is evaluated in a discounted cash flow calculation that yields a discounted cash flow rate of return. A breakeven cost per ton was calculated using the discounted cash flow and annual production rate. The portion of the recoverable coal that is economically minable at a cost that is at or below the current sales price of coal is designated as reserves.

The term "reserves" refers to that portion of the recoverable coal resource that can be mined at a profit at the time of the assessment; therefore, it was necessary to determine the freight on board (FOB) market price. Because the sale of coal is normally based on heating value, the determination of the average regional coal heating value for the MTPRB assessment area was required. On the basis of publically available data, an average heating value of $8,821 \mathrm{Btu} / \mathrm{lb}$ was derived. However, it should be emphasized that the large range in reported coal quality (tables 5-7) and the lack of specific data for every coal bed precluded development of a precise coal quality model. The November, 2011 FOB sales price for 8,800 $\mathrm{Btu} / \mathrm{lb}$ coal from the PRB was $\$ 13.20$ per ton (Platts, 2011a).

Once an estimate of the sales price was determined, the final step in the economic evaluation was determining what portion of the resources could be considered coal reserves (total tons at or below the estimated sales price). To derive a reserve estimate for the MTPRB assessment area, a composite cost curve (fig. 85) was developed for the cumulative total recoverable resources from table 10; the breakeven costs utilized an 8 percent ROR. Using the $\$ 13.20$ per ton FOB sales price, the coal reserve estimate for the MTPRB is about 13 BST (figs. 86, 87).

Reserve estimates are a constantly moving target, as sales prices continually fluctuate, responding to variations in market demand. For example, from June to December 2011, the price for $8,800 \mathrm{Btu} / \mathrm{lb}$ coal from the PRB has fluctuated from a low of $\$ 12.35$ per ton to a high of $\$ 15.15$ per ton (Platts, 2011b, 2011c). As seen in the cost curve (fig. 85), the variation in price can change the reserve estimate significantly.

The results of the MTPRB assessment area coal resources and reserves assessment by tonnages and percentages for the 10 coal beds included in the economic evaluation are summarized in figures 86 and 87 . The $35 \mathrm{BST}$ of recoverable resources, which are only 23 percent of the original resource, represent the total estimated amount of coal that can be produced by surface-mining technologies (figs. 86,87 ). The significant amount of coal affected by all the restrictions to mining and mining losses precludes recovery of all of the original in-place coal resources. Also, the volume of estimated coal reserves is a much smaller subset ( 9 percent) of the original resources than the total recoverable resources (35 percent). The relation of original resources to reserves is consistent with previous USGS coal assessments, which typically determine the reserve fraction to be less than 20 percent (Luppens and others, 2009).

As a basin matures through time with respect to the level of development, resources become progressively more expensive to produce. Sale prices generally increase over the long term and operating costs follow accordingly as long as demand is steady. Resources once considered to be subeconomic, may be elevated to the status of reserves with continued favorable sales prices as well as productivity and 
technological advances in mining. Therefore, reserve studies should be considered a cyclic process and models should be adjusted periodically using the most recent data and reassessed using the most current recovery technology and economics.

\section{Underground Coal Resource Results}

A significant volume of coal resources in the MTPRB assessment area is contained in beds that are at considerable depth; no coal is being recovered by underground mining, nor expected to be in the near future. In as much as there may be underground recovery in the future, however, an underground evaluation was conducted to determine a rough estimate of the magnitude of underground resources.

The minable coal bed thickness for longwall systems is generally from 5 to $13 \mathrm{ft}$ (Thomas, 2002). Although longwall shearers are commonly used for seam thicknesses between 5 and $20 \mathrm{ft}$ (Myszkowski and Paschedag, 2009), a 10-ft minimum was used as a more conservative estimate of potential underground resources for longwall operations. Deeper, in-place resource totals are listed in table 11 for coal beds with a $10-\mathrm{ft}$ minimum thickness and a stripping ratio greater than 10:1. These include the same beds that were evaluated for surface minable deposits. No restrictions to mining were applied to the coal resources listed in table 11. Of the total of about 42 BST of underground tonnage, about 34 BST ( 80 percent) is within $500-1,000 \mathrm{ft}$ of the land surface and another 8 BST is 1,000 $2,000 \mathrm{ft}$ beneath the land surface.

As with other coal basins, only a fraction of the total underground resource is typically recoverable. Factors such as adverse roof and floor conditions, slope of the coal beds, and essential safety barriers between different mining operations, typically present restrictions to mining. Although recovery in multiple bed areas is generally most efficient by mining from the uppermost bed downward, that situation is extremely difficult to control. Additionally, interburden between beds must be thick enough to prevent interbed structural effects. None of these factors were used to develop the model of underground mining described in the Appendix.

\section{Underground Coal Reserves Results}

Breakeven cost analysis was determined for potential underground coal reserves in the MTPRB assessment area in the same manner as described for surface coal reserves (see Appendix for detailed discussion of underground mine models and assumptions). The breakeven cost per ton was determined using the previously described longwall mine model. Four separate mine models were developed using either 10- or $20-\mathrm{ft}$ coal thickness and either 1,000-or 2,000-ft depth (table 12). The overall capital cost for mining 6 MST of coal for 20 years, based on a 10 -ft-thick bed at a depth of $1,000 \mathrm{ft}$, was estimated at $\$ 386$ million, with $\$ 3,218$ million in operating cost (table 12, Case 1). The breakeven cost per ton was calculated to be $\$ 30.94$ (table 12). The cost per ton decreases slightly as thickness increases to $20 \mathrm{ft}$ (table 12, Cases 2 and 4). 
Table 11. Underground resources in beds at least 10 feet thick and a strip ratio of greater than 10:1, in the Montana Powder River Basin assessment area.

\begin{tabular}{|c|c|c|c|c|}
\hline Coal bed name & $\begin{array}{l}\text { Depth } \\
\text { (feet) }\end{array}$ & $\begin{array}{l}\text { Underground tonnage } \\
\text { (millions of short tons) }\end{array}$ & $\begin{array}{c}\text { Acreage } \\
\text { (acres) }\end{array}$ & $\begin{array}{c}\text { Average } \\
\text { thickness (feet) }\end{array}$ \\
\hline \multirow{5}{*}{ Anderson } & $500-1,000$ & 897 & 21,239 & 24 \\
\hline & $1,000-2,000$ & 0 & 0 & 22 \\
\hline & $2,000-3,000$ & 0 & 0 & 0 \\
\hline & $>3,000$ & 0 & 0 & 0 \\
\hline & Total & 897 & 21,239 & Not applicable \\
\hline \multirow{5}{*}{ Dietz 2} & $500-1,000$ & 123 & 4,527 & 15 \\
\hline & $1,000-2,000$ & 0 & 0 & 0 \\
\hline & $2,000-3,000$ & 0 & 0 & 0 \\
\hline & $>3,000$ & 0 & 0 & 0 \\
\hline & Total & 123 & 4,527 & Not applicable \\
\hline \multirow{5}{*}{ Dietz 3} & $500-1,000$ & 754 & 23,992 & 18 \\
\hline & $1,000-2,000$ & 6 & 271 & 13 \\
\hline & $2,000-3,000$ & 0 & 0 & 0 \\
\hline & $>3,000$ & 0 & 0 & 0 \\
\hline & Total & 760 & 24,263 & Not applicable \\
\hline \multirow{5}{*}{ Canyon } & $500-1,000$ & 4,163 & 134,495 & 17 \\
\hline & $1,000-2,000$ & 70 & 2,463 & 16 \\
\hline & $2,000-3,000$ & 0 & 0 & 0 \\
\hline & $>3,000$ & 0 & 0 & 0 \\
\hline & Total & 4,233 & 136,958 & Not applicable \\
\hline
\end{tabular}


Table 11. Underground resources in beds at least 10 feet thick and a strip ratio of greater than 10:1, in the Montana Powder River Basin assessment area.-Continued

\begin{tabular}{|c|c|c|c|c|}
\hline Coal bed name & $\begin{array}{l}\text { Depth } \\
\text { (feet) }\end{array}$ & $\begin{array}{l}\text { Underground tonnage } \\
\text { (millions of short tons) }\end{array}$ & $\begin{array}{c}\text { Acreage } \\
\text { (acres) }\end{array}$ & $\begin{array}{c}\text { Average } \\
\text { thickness (feet) }\end{array}$ \\
\hline \multirow[t]{5}{*}{ Lower Canyon } & $500-1,000$ & 2,408 & 98,199 & 14 \\
\hline & $1,000-2,000$ & 119 & 5,427 & 12 \\
\hline & $2,000-3,000$ & 0 & 0 & 0 \\
\hline & $>3,000$ & 0 & 0 & 0 \\
\hline & Total & 2,527 & 103,626 & Not applicable \\
\hline \multirow[t]{5}{*}{ Werner/Cook } & $500-1,000$ & 6,963 & 147,873 & 27 \\
\hline & $1,000-2,000$ & 39 & 1,538 & 14 \\
\hline & $2,000-3,000$ & 0 & 0 & 0 \\
\hline & $>3,000$ & 0 & 0 & 0 \\
\hline & Total & 7,002 & 149,411 & Not applicable \\
\hline \multirow{5}{*}{ Pawnee } & $500-1,000$ & 1,855 & 66,247 & 16 \\
\hline & $1,000-2,000$ & 639 & 29,981 & 12 \\
\hline & $2,000-3,000$ & 0 & 0 & 0 \\
\hline & $>3,000$ & 0 & 0 & 0 \\
\hline & Total & 2,494 & 96,228 & Not applicable \\
\hline \multirow{5}{*}{ Rosebud/Knobloch } & $500-1,000$ & 10,271 & 279,220 & 21 \\
\hline & $1,000-2,000$ & 1,251 & 42,354 & 17 \\
\hline & $2,000-3,000$ & 0 & 0 & 0 \\
\hline & $>3,000$ & 0 & 0 & 0 \\
\hline & Total & 11,522 & 321,574 & Not applicable \\
\hline \multirow{5}{*}{ Flowers-Goodale } & $500-1,000$ & 6,468 & 225,224 & 16 \\
\hline & $1,000-2,000$ & 5,854 & 225,587 & 15 \\
\hline & $2,000-3,000$ & 3 & 145 & 0 \\
\hline & $>3,000$ & 0 & 0 & 0 \\
\hline & Total & 12,325 & 450,956 & Not applicable \\
\hline \multirow{5}{*}{ Total } & $500-1,000$ & 33,902 & $1,001,016$ & Not applicable \\
\hline & $1,000-2,000$ & 7,978 & 307,621 & Not applicable \\
\hline & $2,000-3,000$ & 3 & 145 & Not applicable \\
\hline & $>3,000$ & 0 & 0 & Not applicable \\
\hline & Total & 41,882 & $1,405,010$ & Not applicable \\
\hline
\end{tabular}


Table 12. Costs by underground mining case for the Montana Powder River Basin assessment area based on a 20-year project life at an annual production rate of 6 million tons per year. All major costs are shown in mid-calendar year 2010 dollar values.

\begin{tabular}{lcccc}
\hline & Case 1 & Case 2 & Case 3 & Case 4 \\
\hline Mining height (feet) & 10 & 20 & 10 & 20 \\
Depth (feet) & 1,000 & 1,000 & 2,000 & 2,000 \\
Capital cost (millions of dollars) & 385.6 & 375.9 & 408.6 & 400.9 \\
Depreciation (millions of dollars) & 167.9 & 164.7 & 172.7 & 168.9 \\
Operation cost (millions of dollars) & $3,218.5$ & $3,166.8$ & $3,276.2$ & $3,227.3$ \\
Breakeven cost (dollars per short ton) & $\mathbf{\$ 3 0 . 9 4}$ & $\mathbf{\$ 3 0 . 4 0}$ & $\mathbf{\$ 3 1 . 6 9}$ & $\mathbf{\$ 3 1 . 2 0}$ \\
\hline
\end{tabular}

\section{Conclusions}

The MTPRB is the last of four coal resource and reserve assessment reports within the Powder River Basin, Wyoming and Montana. A total of 26 coal beds were identified during this assessment, 18 of which were modeled and evaluated to determine in-place coal resources. The total original coal resource in the Montana Powder River Basin assessment area for the 18 coal beds assessed, with no restrictions applied, was calculated to be 215 BST. Available coal resources, which are part of the original coal resource remaining after subtracting restrictions and areas of burned coal, are about 162 BST. Restrictions included railroads, federal interstate highways, urban areas, alluvial valley floors, state parks, national forests, and previously mined areas.

Ten of the 18 coal beds each had sufficient areal extent and thickness to be evaluated for recoverable resources (Roland (Baker), Smith, Anderson, Dietz 2, Dietz 3, Canyon, Werner/Cook, Pawnee, Rosebud/Knobloch, and FlowersGoodale). These beds totaled about 151 BST of the 162 BST of available resource. At a strip ratio of 10:1 or less, only 39 BST remained of the available resource of 151 BST. After mining and processing losses were subtracted from the $39 \mathrm{BST}, 35$ BST of coal were considered as a recoverable resource. Coal reserves (economically recoverable coal) are the portion of the recoverable coal resource that can be mined, processed, and marketed at a profit at the time of the economic evaluation. The coal reserves estimate for the 10 coal beds evaluated for the Montana Powder River assessment area is 13 BST.

About 42 BST of underground resource exists in the assessment area; about 34 BST ( 80 percent) are at depths 500 $1,000 \mathrm{ft}$ and another $8 \mathrm{BST}$ are at depths 1,000-2,000 ft. Breakeven cost analysis was determined for potential underground coal reserves in the MTPRB assessment area, using a longwall mine model. Four separate mine models were developed using both 10 - and $20-\mathrm{ft}$ coal thicknesses and either 1,000- or 2,000-ft depths. The overall capital cost for mining 6 MST of coal for 20 years, based on a $10-\mathrm{ft}$-thick bed at a depth of $1,000 \mathrm{ft}$, was estimated at $\$ 386$ million, with $\$ 3,218$ million in operating cost. The breakeven cost per ton was calculated to be $\$ 30.94$. The cost per ton decreases slightly as thickness increases to $20 \mathrm{ft}$.

\section{Acknowledgments}

This report was produced as a result of the efforts and cooperation of many people. Ed Heffern, U.S. Bureau of Land Management in Cheyenne, Wyoming, supplied the digital files that show the extent of clinker within the Montana Powder River Basin assessment area. Tim Grant, National Energy Technology Laboratory, U.S. Department of Energy; and Carol Molnia, Dick Keefer, and Margaret Ellis, all of the USGS, provided technical reviews of the manuscript.

\section{References Cited}

Association for the Advancement of Cost Engineering, 1997, Cost estimate classification system-As applied in engineering, procurement, and construction for the process industries: Association for the Advancement of Cost Engineering International Recommended Practice No. 18R-97, Morgantown, W. Va., p. 27-7.

Association for the Advancement of Cost Engineering, 1999, Skills and knowledge of cost engineering, 4th edition: Association for the Advancement of Cost Engineering Morgantown, WV, p.27-7.

Averitt, Paul, 1966, Coal in Proceedings of the first Montana coal resources symposium: Montana Bureau of Mines and Geology, Special Publication 36, March, 1966, 89 p.

Ayler, M.F., Smith, J.B., and Deutman, G.M., 1969, Strippable coal reserves of Montana: U.S. Bureau of Mines Preliminary Report 172, March, 1969, 68 p.

BNSF Railway, 2010, Guide to coal mines: Forth Worth, Tex., BNSF Railway, Coal business unit, $37 \mathrm{p}$.

Brown, J.L., 1993, Sedimentology and depositional history of the Lower Paleocene Tullock Member of the Fort Union Formation, Powder River Basin, Wyoming and Montana: U.S. Geological Survey Bulletin 1917, 41 p., 3 plates. 
Carter, M.D., and Gardner, N.K., 1989, An assessment of coal resources available for development: U.S. Geological Survey Open-File Report 89-362, 52 p.

Coates, D.A., and Heffern, E.L., 1999, Origin and geomorphology of clinker in the Powder River Basin, Wyoming and Montana, in Miller, W.R., ed., Coal bed methane and the Tertiary geology of the Powder River Basin: Wyoming Geological Association 50th Annual Field Conference Guidebook, p. 211-229, 1 plate.

Combo, J.X., Brown, D.M., Pulver, H.F., and Taylor, D.A., 1949, Coal resources of Montana: U.S. Geological Survey Circular 53, 28 p.

Culbertson, W.C., 1987, Diagrams showing proposed correlation and nomenclature of Eocene and Paleocene coal beds in the Birney 30' x 60' quadrangle, Big Horn, Rosebud, and Powder River Counties, Montana: U.S. Geological Survey Coal Investigations Map C-113, scale 1:100,000.

Culberston, W.C., Kent, B.H., and, Mapel, W.J., 1979, Preliminary diagrams showing correlation of coal beds in the Fort Union and Wasatch Formations across the northern Powder River Basin, northeastern Wyoming and southeastern Montana: U.S. Geological Survey Open-File Report 79-1201, 11 p., 2 diagrams, no scale.

Culbertson, W.C., and Saperstone, H.I., 1987, Structure, coal thickness, and overburden thickness of the Knobloch coal resource unit, Birney area, Big Horn, Rosebud, and Powder River Counties, Montana: U.S. Geological Survey Coal Investigations Map C-112, scale 1:100,000.

De Bruin, R.H., Lyman, R.M., Jones, R.W., and Cook, L.W., 2004, Coal bed methane in Wyoming: Wyoming State Geological Survey Information Pamphlet 7, second revision, 24 p.

Denson, N.M., Macke, D.L., Schumann, R.R., and Murrett, M.E., 1990, Geologic map and distribution of heavy minerals in Tertiary rocks of the Birney 30' x 60' quadrangle, Big Horn, Rosebud, and Powder River counties, Montana: U.S. Geological Survey Miscellaneous Investigations Map I-2019, scale 1:200,000.

Department of Labor and Industry Safety and Health Bureau, State of Montana, P.O. Box 1728, Helena, MT, 59624.

Department of the Treasury, Internal Revenue Service, 2008, How to depreciate property: Washington D.C., Internal Revenue Service Publication 946, No. 13081-F.

Derkey, P.D., 1986, Coal stratigraphy of the Lame Deer 30' x 60' Quadrangle, southeastern Montana: Montana Bureau of Mines and Geology Geologic Map 43, 4 maps, 1:100,000 scale.

Dobbin, C.E., 1929, The Forsyth coal field, Rosebud, Treasure, and Big Horn Counties, Montana: U.S. Geological Survey Bulletin 812, 55 p.
Eggleston, J.R., Carter, M.D., and Cobb, J.C., 1990, Coal resources available for development-A methodology and pilot study: U.S. Geological Survey Circular 1055, 15 p.

Ellis, M.S., Flores, R.M., Ochs, A.M., Stricker, G.D., Gunther, G.L., Rossi, G.S., Bader, L.R., Schuenemeyer, J.H., and Power, H.C., 1999a, Gillette coalfield, Powder River Basin: Geology, coal quality, and coal resources - Chapter PG in Fort Union Coal Assessment Team,1999 resource assessment of selected Tertiary coal beds and zones in the northern Rocky Mountains and Great Plains region: U.S. Geological Survey Professional Paper 1625-A, 2 CD-ROMs.

Ellis, M.S., Flores, R.M., Ochs, A.M., Stricker, G.D., Gunther, G.L., Rossi, G.S., Bader, L.R., Schuenemeyer, J.H., and Power, H.C., 1999b, Sheridan coalfield, Powder River Basin: Geology, coal quality, and coal resources - Chapter PG in Fort Union Coal Assessment Team,1999 resource assessment of selected Tertiary coal beds and zones in the northern Rocky Mountains and Great Plains region: U.S. Geological Survey Professional Paper 1625-A, 2 CD-ROMs.

Ellis, M.S., Molnia, C.L, Osmonson, L.M., Ochs, A.M., Rohrbacher, T.J., Mercier, T., and Roberts, N.R., 2002, Evaluation of economically extractable coal resources in the Gillette coal field, Powder River Basin, Wyoming: U.S. Geological Survey Open-File Report 2002-180, 48 p.

Ellis, M.S., and Colton, R.B., 1994, Geologic map of the Powder River Basin and surrounding area, Wyoming, Montana, South Dakota, North Dakota, and Nebraska: U.S. Geological Survey Miscellaneous Investigations Series, Map I-12298, 1 sheets, scale 1:500,000.

Environmental Systems Research International, Incorporated, 2000, ArcView software version 3.2a: Redlands, Calif., Environmental Systems Research International, Incorporated.

Environmental Systems Research International, Incorporated, 2001, ArcView spatial analyst extension software version 2.0: Redlands, Calif., Environmental Systems Research International.

Environmental Systems Research International, Incorporated, 2006, ArcGIS software version 9.2: Redlands, Calif., Environmental Systems Research International, Incorporated.

Flores, R.M., Ochs, A.M., Bader, L.R., Johnson, R.C., and Vogler, D., 1999, Framework geology of the Fort Union coal in the Powder River Basin,- - Chapter PF in Fort Union Coal Assessment Team,1999 Resource assessment of selected Tertiary coal beds and zones in the northern Rocky Mountains and Great Plains Region: U.S. Geological Survey Professional Paper 1625-A, 2 CD-ROMs.

Flores, R.M., and Bader, L.R., 1999, Fort Union coal in the Powder River Basin, Wyoming and Montana: A synthesis,-Chapter PS in Fort Union Coal Assessment Team,1999 Resource assessment of selected Tertiary coal 
beds and zones in the Northern Rocky Mountains and Great Plains Region: U.S. Geological Survey Professional Paper 1625-A, 2 CD-ROMs.

Gilmour, E.H., and Dahl, G.G., 1967, Montana coal analyses: Montana Bureau of Mines and Geology Special Publication 43, $21 \mathrm{p}$.

Golden Software, Inc. Surfer8 software, 2002: Golden, Colo., Golden Software, Inc.

GRG Corporation, StratiFact software version 4.57, 1998: Wheat Ridge, Colo., GRG Corporation.

Groff, S.L., 1968, Montana's place in the nation's coal energy picture in Kube, W.R., and Elder, J.L., compliers, Technology and use of lignite: U.S. Bureau of Mines Information Circular 8376, p. 40-56.

Haacke, J.E., and Scott, D.C., 2012, Drill hole data for coal beds in the Powder River Basin, Montana and Wyoming: U.S. Geological Survey Data Series 173, 26 p.

Heffern, E.L., Coates, D.A., Whiteman, Jason, and Ellis, M.S., 1993, Geologic map showing distribution of clinker in the Tertiary Fort Union and Wasatch Formations, northern Powder River Basin, Montana: U.S. Geological Survey Coal Investigations Map C-142, 1 map, 1:175,000 scale.

InfoMine USA, Inc., 2010, Mining cost service: Spokane Valley, Wash., InfoMine USA, Inc.

Kent, B.H., Berlage, L.J., and Boucher, E.M., 1980, Stratigraphic framework of coal beds underlying the western part of the Recluse $1 \times 1 / 2$-degree quadrangle, Campbell, Wyoming: U.S. Geological Survey Coal Investigations Map C-81C, 2 plates, scale: 1:100,000.

Law, B.E., Barnum, B.E., and Wollenzien, T.P., 1979, Coal bed correlations in the Tongue River Member of the Fort Union Formation, Monarch, Wyoming, and Decker, Montana, areas: U.S. Geological Survey Miscellaneous Investigations Series Map I-1128, scale 1:24,000.

Lopez, D.A., 2005, Structure contour map: Top of Lebo Shale and Bear Paw Shale, Powder River Basin, southeast Montana: Montana Bureau of Mines and Geology Report of Investigations 16, 3 sheets, 1:25,000 scale.

Lopez, D.A., and Heath, L.A., 2007, CBM-produced water disposal by injection, Powder River Basin, Montana: Montana Bureau of Mines and Geology Report of Investigations 17,30 p., 3 sheets.

Luppens, J.A., Scott, D.C., Haacke, J.E., Osmonson, L.M., Rohrbacher, T.J., and Ellis, M.S., 2008, Assessment of coal geology, resources, and reserves in the Gillette coal field, Powder River Basin, Wyoming: U.S. Geological Survey Open-File Report 2008-1202, 127 p.
Luppens, J.A., Rohrbacher, T.J., Osmonson, L.M., and Carter, M.D., 2009, Coal resource availability, recoverability, and economic evaluations in the United States-A summary, in Pierce, B.S., and Dennen, K.O., eds., The national coal resource assessment overview: U.S. Geological Survey Professional Paper 1625-F, Chapter D, 17 p.

Matson, R.E., Dahl, G.G., and Blumer, J.W., 1968, Strippable coal deposits on state land, Powder River County, Montana: Montana Bureau of Mines and Geology Bulletin 69, August 1968, $81 \mathrm{p}$.

Matson, Robert E., 1971, Strippable coal in the Moorhead coal field, Montana: Montana Bureau of Mines and Geology Bulletin 83, 18 p., 1 plate.

Matson, R.E., and Blumer, J.W., 1973, Quality and reserves of strippable coal, selected deposits, southeastern Montana: Montana Bureau of Mines and Geology Bulletin 91, December 1973, $135 \mathrm{p}$.

Matson, T., and White, D., Jr., 1975, The reserve base of coal for underground mining in the western United States: U.S. Bureau of Mines Information Circular 8678, 238 p.

McLellan, M.W., Biewick, L.R., Molnia, C.L., and Pierce, F.W., 1990, Cross sections showing the reconstructed stratigraphic framework of Paleocene rocks and coal beds in the northern and central Powder River Basin, Montana, and Wyoming: U.S. Geological Survey Miscellaneous Investigations Series Map I-1959-A, 2 sheets, scale 1:500,000.

Mentor Consultants, 2005, PC/Cores: Glen Ellyn, Ill.

Microsoft, 2007, Excel spreadsheet software, v. Office 2007: Redman, Wash., Microsoft Corporation.

MJ Systems, 2009, Denver, Colo.

Molnia, C.L., and Pierce, F.W., 1992, Cross sections showing coal stratigraphy of the central Powder River Basin, Wyoming and Montana: U.S. Geological Survey Miscellaneous Investigations Series Map I-1959-D, 1 sheet, scale 1:500,000.

Molnia, C.L., Osmonson, L.M., Wilde, E.M., Biewick, L.R.H., Rohrbacher, T.J., and Carter, M.D., 1999, Coal availability and recoverability studies in the Powder River Basin, Wyoming and Montana, Chapter PAR in Fort Union Coal Assessment Team, 1999 resource assessment of selected Tertiary coal beds and zones in the northern Rocky Mountains and Great Plains Region: U.S. Geological Survey Professional Paper 1625-A, 119 p.

Montana Bureau of Mines and Geology Geographic Information Systems Lab, on line data base, accessed May 2011 at http://www.mbmg.mtech.edu/gis/gis-datalinks.asp

Montana Board of Oil and Gas, 2011, on line data base, accessed June 2011 at http://www.bogs.dnrc.mt.gov 
Morgan, Thomas, 1966, History of coal mining in Montana in Groff, S.L., complier, Proceedings of the first Montana coal resources symposium: Montana Bureau of Mines and Geology, Special Publication 36, 89 p.

Moulton, G.E., editor, 2001, The journals of the Lewis and Clark expedition: Lincoln, Nebr., University of Nebraska Press, 576 p.

Myszkowski, M. and Paschedag, U., 2009, Longwall mining in seams of medium thickness-Comparison of plow and shearer performance under comparable conditions: Milwaukee, Wis., Bucyrus, 34 p. accessed June, 2009 at http:// www.bucyrus.com/media/5712/longwall_extraction_of_ medium_thickness_coal_seams.pdf

Natural Resource Information System GIS, 2011, data list of the Montana government, 2011: Natural Resource Information System, accessed May 2011 at http://nris.mt.gov/gis/ gisdatalib/gisDataList.aspx

Office of the Federal Register, 2003, Code of federal regulations, Title 43, Part 3460, Subpart 3461.5: National Archives and Records Administration, p. 588-593, accessed June 2009 at http://www.gpoaccess.gov/cfr/retrieve.html

Olive, W.W., 1957, The Spotted Horse coal field, Sheridan and Campbell counties, Wyoming: U.S. Geological Survey Bulletin 1050, 83 p.

Osmonson L.M., Scott, D.C., Haacke, J.E., Luppens, J.A., and Pierce, P.E., 2011, Assessment of coal geology, resources, and reserves in the Southwestern Powder River Basin, Wyoming: U.S. Geological Survey Open-File Report 2011-1134, 135 p.

Pierce, B.S., and Dennen, K.O., eds., 2009, The national coal resource assessment overview: U.S. Geological Survey Professional Paper 1625-F, 402 p.

Platts, 2011a, Coal outlook: New York, Platts, a division of The McGraw-Hill Companies, v. 35, no. 46, 16 p.

Platts, 2011b, Coal outlook: New York, Platts, a division of The McGraw-Hill Companies, v. 35, no. 20, 14 p.

Platts, 2011c, Coal outlook: New York, Platts, a division of The McGraw-Hill Companies, v. 35, no. 42, 12 p.

Public Law 95-87, 1977, Surface Mining Control and Reclamation Act of 1977, (30 U.S.C. 1201 et seq.), 115 p., accessed June 2009 at http://www.osmre.gov/smcra.htm

Roberts, S.B., Wilde, E.M., Rossi, G.S., Blake, D., Ellis, M.S., Stricker, G.D., Ochs, A.M., Gunther, G.L., Schuenemeyer, J.H., and Power, H.C., 1999a, Ashland coal field, Powder River Basin, Montana: geology, coal quality, and coal resources, Chapter PA in Fort Union Coal Assessment Team, 1999 Resource assessment of selected Tertiary coal beds and zones in the northern Rocky Mountains and Great Plains Region: U.S. Geological Survey Professional Paper 1625-A, 2 CD-ROMs.

Roberts, S.B., Wilde, E.M., Rossi, G.S., Blake, D., Bader, L.R., Ellis, M.S., Stricker, G.D., Gunther, G.L., Ochs, A.M., Kinney, S.A., Schuenemeyer, J.H., and Power, H.C.,1999b, Colstrip coal field, Powder River Basin, Montana: geology, coal quality, and coal resources, Chapter PC in Fort Union Coal Assessment Team, 1999 Resource assessment of selected Tertiary coal beds and zones in the northern Rocky Mountains and Great Plains Region: U.S. Geological Survey Professional Paper 1625-A, 2 CD-ROMs.

Roberts, S.B., Gunther, G.L., Taber, T.T., Ochs, A.M., Blake, D., Ellis, M.S., Stricker, G.D., Wilde, E.M., Schuenemeyer, J.H., and Power, H.C., 1999c, Decker coal field, Powder River Basin, Montana: geology, coal quality, and coal resources, Chapter PD in Fort Union Coal Assessment Team, 1999 Resource assessment of selected Tertiary coal beds and zones in the northern Rocky Mountains and Great Plains Region: U.S. Geological Survey Professional Paper 1625-A, 2 CD-ROMs.

Robinson, L.N., and Van Gosen, B.S., 1986, Maps showing the coal geology of the Sarpy Creek area, Big Horn and Treasure counties, Montana: U.S. Geological Survey Miscellaneous Field Studies Map MF-1859, scale 1:24,000.

Rohrbacher, T.J., and McIntosh, G.E., 2010, CoalVal-A coal resource valuation program: U.S. Geological Survey OpenFile Report 2009-1282, 265 p.

Scott, D.C., Haacke, J.E., Osmonson L.M., Luppens, J.A., Pierce, P.E., and Rohrbacher, T.J., 2010, Assessment of coal geology, resources, and reserves in the Northern Wyoming Powder River Basin, Wyoming: U.S. Geological Survey Open-File Report 2010-1294, 136 p.

Society for Mining, Metallurgy, and Exploration, 1992, SME Mining Engineering Handbook, v. 1, p. 931, Howard L. Harman (Sr. Ed.), Society of Mining, Metallurgy and Exploration, Inc.

Supreme Court of the United States, 1999, Amoco Production Co. v. Southern Ute Tribe (98-830), 526, U.S. 865.

Thomas, Larry, Dargo Associates Ltd., 2002, Coal geology: West Sussex, England, John Wiley and Sons, LTD.

Thrush, P.W., and the Staff of the Bureau of Mines, 1968, A dictionary of mining, mineral, and related terms: U.S. Bureau of Mines, 1,269 p.

Tudor, M.S., 1975, Geologic exploration and development of coal in the Sarpy Creek area, Big Horn County, Montana, in Doroshenko, J., Miller, W.R., Thompson, E.E., Jr., and Rawlins, J.H., eds., Energy resources of Montana: Montana Geological Society 22nd Annual Publication, p. 159-164. 
U.S. Energy Information Administration, 2010, Energy glossary: accessed September 2010 at http://www.eia.doe.gov/ glossary/index.cfm

U.S. Environmental Protection Agency, 1980, Standards of performance for new stationary source-A compilation as of July 1, 1980: Washington, D.C., U.S. Environmental Protection Agency, Office of General Enforcement, Division of Stationary Source Enforcement, 868 p., accessed September 2010 at http://nepis.epa.gov/Exe/ZyNET. exe/2000WROU.txt

U.S. Environmental Protection Agency, 2005, AirControl NET Documentation report, Pechan Report No. 05.09.009/9010.463, Springfield, Va., H.E, Pechan \& Associates, 1685 p., accessed September 2010 at http:// www.epa.gov/air/ozonepollution/SIPToolkit/documents/ DocumentationReport.pdf

U.S. Office of Surface Mining, 1983, Draft environmental impact statement for Western Energy Company's Rosebud Mine: Office of Surface Mining 83-10, p. 1-1.

Van Voast, W., and Thale, P., 2001, Anderson and Knobloch coal horizons and potential for methane development, Powder River Basin, Montana: Montana Bureau of Mines and Geology Geologic Map 60, scale 1:250,000.

Vuke, S.M., Heffern, E.L., Bergantino, R.N., and Colton, R.B., 2001a, Geologic map of the Lame Deer 30' x 60' quadrangle, eastern Montana: Montana Bureau of Mines and Geology Open-File Report 428, 8 p., 1 sheet, scale 1:100,000.

Vuke, S.M., Heffern, E.L., Bergantino, R.N., and Colton, R.B., 2001b, Geologic map of the Birney 30' x 60' quadrangle, eastern Montana: Montana Bureau of Mines and Geology Open-File Report 431, 12 p., 1 sheet, scale, 1:100,000.

Vuke, S.M., Heffern, E.L., Bergantino, R.N., and Colton, R.B., 2001c, Geologic map of the Broadus 30' x 60' quadrangle, eastern Montana: Montana Bureau of Mines and Geology Open-File Report 432, 13 p., 1 sheet, scale 1:100,000.

Wilde, E.M., 2000, Availability of the coal resources of the Willow Crossing 7.5' quadrangle, Rosebud and Powder River Counties, Montana: Montana Bureau of Mines and Geology Report of Investigations 6, 26 p.

Wilde, E.M., and Myers, W.H., 2003, Availability of the coal resources of the Colstrip East and Colstrip SW 7.5' quadrangles, Rosebud and Bighorn Counties, Montana: Montana Bureau of Mines and Geology Report of Investigations 11, $163 \mathrm{p}$.

Wilde, E.M., and Sandau, K.L., 2004, Availability of the coal resources of the Otter and Reanus Cone 7.5' quadrangle, Powder River County, Montana: Montana Bureau of Mines and Geology, Report of Investigations 12, 83 p., 1 CD ROM.
Wilde, E.M., and Sandau, K.L., 2005, Availability of the coal resources of the Half Moon Hill and Taintor Desert 7.5' quadrangles, Rosebud and Big Horn Counties, Montana: Montana Bureau of Mines and Geology, Report of Investigations 14, 101 p., 1 CD ROM.

Wilde, E.M., 2001-2010, Coal geology of Montana in Peter Johnson, publisher, Keystone Coal Industry Manual, Mining Media International, 11555 Central Parkway, Suite 401, Jacksonville, FL, 32224.

Wood, G.H., Jr., Kehn, T.M., Carter, M.D., and Culbertson, W.C., 1983, Coal resource classification system of the U.S. Geological Survey: U.S. Geological Survey Circular 891, $65 \mathrm{p}$.

Wyoming Oil and Gas Conservation Commission, 2011, on line data base accessed June 2011 at http://wgiac2.state.wy.us

\section{Glossary}

The present study includes determinations of original, available, recoverable, and economically recoverable (reserves) resources. This terminology has been used in many USGS coal studies (see Wood and others, 1983; Carter and Gardner, 1989; Eggleston and others, 1990; and Molnia and others, 1999). The following definitions were applied in this resource evaluation:

- Available coal resources are remaining coal resources that are thick and shallow enough to be mined by either surface or underground methods and that are unencumbered by land use, environmental, societal, regulatory, or technologic restrictions as they may apply in a specific State or region (Carter and Gardner, 1989).

- Clinker material that is produced where coal beds burn naturally beneath the ground (Coates and Heffern, 1999).

- Coal reserves are virgin or accessed parts of a coal reserve base which could be economically extracted or produced at the time of determination considering environmental, legal, and technologic constraints. The term "reserves" need not signify that extraction facilities are in place or operative. Reserves include only recoverable coal; thus, terms such as "extractable reserves" are redundant and are not a part of the classification system. Reserves can be categorized as "measured" and "indicated," as underground or surface minable, by thickness of overburden, by thickness of coal in the bed, and by various quality factors (Wood and others, 1983).

- Coal resources are naturally occurring concentrations or deposits of coal in the Earth's crust, in such forms 
and amounts that economic extraction is currently or potentially feasible (Wood and others, 1983).

- Demonstrated resource is a term commonly used for the sum of coal classified as measured and indicated resources (Wood and others, 1983).

- Dip (dipping) is the angle at which a bed, stratum, or vein is inclined from the horizontal (Thrush, and the staff of the Bureau of Mines, 1968).

- Discounted cash flow is the stream of the net aftertax cash flows where the cash outlays include all operating costs, taxes, and investment costs, and where revenues include cash payments of product sales (Association for the Advancement of Cost Engineering, 1997).

- Freight on Board (FOB) is a reference to the place where purchased goods will be shipped without transportation charge.

- Headgate is the primary roadway access and egress through which equipment, personnel, and supplies are provided to a longwall face, through which coal is conveyed to the surface, and through which fresh air flows (Stermole, 1974).

- Hypothetical—Tonnage estimates computed by extrapolation of thicknesses of coal for a radius beyond $3.0 \mathrm{mi}(4.8 \mathrm{~km}$ ) from a point of measurement (Wood and others, 1983).

- Hypothetical resources are a class of undiscovered resources that are either similar to known coal deposits which may be reasonably expected to exist in the same coal field or region under analogous geologic conditions, or are an extension from inferred resources (Wood and others, 1983).

- Identified resources are resources whose locations, rank, quality, and quantity are known or estimated from specific geologic evidence. Identified coal resources include economic, marginally economic, and subeconomic components. To reflect varying distances from points of control or reliability, these subdivisions can be divided into demonstrated and inferred, or preferably into measured, indicated, and inferred (Wood and others, 1983).

- Indicated-Tonnage estimates computed by extrapolation of thicknesses of coal for a radius of 0.25 to $0.75 \mathrm{mi}(0.4$ to 1.2 kilometers $(\mathrm{km}))$ from a point of measurement (Wood and others, 1983).

- Inferred-Tonnage estimates computed by extrapolation of thicknesses of coal for a radius of 0.75 to 3.0 $\mathrm{mi}(1.2$ to $4.8 \mathrm{~km}$ ) from a point of measurement (Wood and others, 1983).
- Interburden is the rock between two coal beds. When two potentially minable coal beds occur within a minimum acceptable distance above or below on another, one will not be mined-often the thinner of the two (Carter and Gardner, 1989).

- Measured-Tonnage estimates computed by extrapolation of thicknesses of coal for a radius of $0.25 \mathrm{mi}$ $(0.4 \mathrm{~km})$ from a point of measurement (Wood and others, 1983).

- Original coal resource is the total amount of coal in-place before production. Where mining has occurred, the total of original resources is the sum of the identified resources, undiscovered resources, coal produced, and coal lost in mining (Wood and others, 1983).

- Overburden is rock including coal or unconsolidated material that overlies a specified coal bed. Overburden is reported in feet or meters and is used to classify the depth to an underlying coal bed (Wood and others, 1983).

- Outcrop is that part of a rock formation (coal bed) that appears at the surface of the ground (Thrush, 1968).

- Parting is a thin layer of stratum or noncoaly material within a coal bed that does not exceed the thickness of coal in either the directly underlying or overlying benches (Wood and others, 1983).

- Previously mined coal is coal that has already been extracted from a deposit.

- Rate of return (ROR) is the ratio of money gained or lost relative to the amount of money invested (Association for the Advancement of Cost Engineering, 1999).

- Recoverable coal resource is coal that is or can be extracted from a coal bed during mining. The term "recoverable" should be used in combination with "resources" and not with "reserves" (Wood and others, 1983).

- Reliability categories are based on the distance from points of measurement or sampling. The measured, indicated, inferred, and hypothetical resource categories, as defined, indicate the relative reliability of tonnage estimates as related to distance from points of thickness control of particular parts of a coal deposit. The reliability categories are not indicative of the reliability of the basic data (that is, the accuracy of coal measurements, or the accuracy of location of the coal outcrop). It is assumed that all basic data used in resource estimation have been judged reliable by the estimator and that unreliable data have been discarded (Wood and others, 1983). 
- Remaining resources represent resources in the ground after subtracting coal that has been previously mined from the original resource (Carter and Gardner, 1989).

- Restrictions to mining include land use restrictions, technical limitations, and unsuitability criteria that would prohibit mining, as defined below:

- Land use restrictions are constraints placed upon mining by societal policies to protect those surface features or entities that could be harmed by mining. Since laws and regulations can be modified or repealed, the restrictions, including industrial and environmental restrictions, may change. Land use restrictions include railroads, cities and towns, airports, and interstate highways.

- Technical restrictions are constraints, relating to economics and safety, placed upon mining by the state of technology or prescribed by law. These restrictions can change with advances in science and technology, or modifications in the law. In this report, some geologic factors are included as technologic restrictions. Technical restrictions include coal between $2.5 \mathrm{ft}$ and $5.0 \mathrm{ft}$ thick and clinker areas.

- Unsuitability criteria are specific legal constraints used to determine if an area can be mined by surface mining methods. These include, but are not limited to, federal land systems, dwellings, and alluvial valley floors.

- Strip (stripping) ratio represents the ratio of the volume of overburden or interburden (waste) that must be removed to gain access to a unit amount of coal. For this assessment, the ratio is expressed as cubic yards of overburden to tons of coal. The stripping ratio can be approximated by dividing the total thickness of waste by the total thickness of coal. For example, given two coal beds each $5.0 \mathrm{ft}$ thick at 50 and $105 \mathrm{ft}$ in depth, the total waste and coal thicknesses would be 100 and $10 \mathrm{ft}$ respectively. A simple ratio would be 10:1, but a stripping ratio would be 9.1:1 (in cubic yards to a ton of coal) (Thrush, 1968).

- Surface (strip) mining is mining at or near the ground surface and is generally done where the overburden can be removed economically. A strip mine is a surface mine in which the overburden is removed from a coalbed before the coal is removed (Thrush, 1968).

- Tailgate is the secondary roadway access or egress from a longwall face and through which return air flows (SME, 1992).

\section{Appendix}

\section{Modeling Stratigraphic Sequence for Mining}

Mine models in the MTPRB assessment area differ from those used in the Wyoming Powder River Basin in two respects. First, the coal bed thicknesses in the MTPRB assessment area are more variable than in the NWPRB assessment area of Wyoming (Scott and others, 2010). Also, areas of thicker coal (greater than $20 \mathrm{ft}$ thick) are more pod-like as illustrated by the isopach maps of the Dietz 3, Canyon, Lower Canyon, Werner/Cook, Pawnee, and Flowers-Goodale coal beds (figs. 42, 45, 48, 54, 63, 75). Second, deeply-dissected drainages limit the areal extent of shallow surface minable coal beds in the MTPRB assessment area. Cross sections A-A' and B-B' (figs. 21 and 22) as well as the overburden map for the Werner/ Cook coal bed (fig. 55) illustrate the impacts of the surface morphology. Areas where these coal beds are less than $250 \mathrm{ft}$ deep are in many places limited to relatively narrow bands along the drainages.

To simplify the development of a MTPRB assessment area regional mining model and keep it as realistic as possible, a representative model-bed section was developed based on approximate average thicknesses of 5 coal beds: Roland (Baker), Smith, Anderson, Dietz 2, and Dietz 3 (table 13). The first coal bed is modeled at the 1:1 strip ratio; additional coal beds are added for ratios from $2: 1$ through the $4: 1$. To help simplify the models, interburden thicknesses remain relatively constant and additional overburden is increased for the 5:1+ ratio models. The combined stripping ratio map for the regional mining model stratigraphic sequence was performed on stripping ratios from 1:1 to 10: 1 . The coal bed and overburden thicknesses used in the model are based on average values in the southwestern portion of the MTPRB. An additional coal bed is added to each stripping ratio increment up to the 5:1 ratio. From stripping ratios of $6: 1$ to $10: 1$, the coal bed and interburden thicknesses are fixed and overburden was added above the uppermost coal bed to arrive at higher ratio increments. Three key parameters - coal production, stripping ratio, and rate of return (ROR) - were evaluated as to their effect on the breakeven price per ton for mining coal. The breakeven cost per ton at an 8 percent ROR and resource volume for 1:1 to 10:1 stripping ratios are shown in table 10 . The costs per ton vary from $\$ 7.01$ at a 1:1 ratio to $\$ 29.09$ at a $10: 1$ ratio (table 10 ).

In addition to the regional mining model sequence, the Canyon, Werner/Cook, Pawnee, Rosebud/Knobloch, and Flowers-Goodale coal beds were evaluated for reserve potential. The stripping ratio maps for these coal beds are shown in figures 9-13. The individual coal bed stripping ratio maps demonstrate the relation between the deeply-dissected surface 


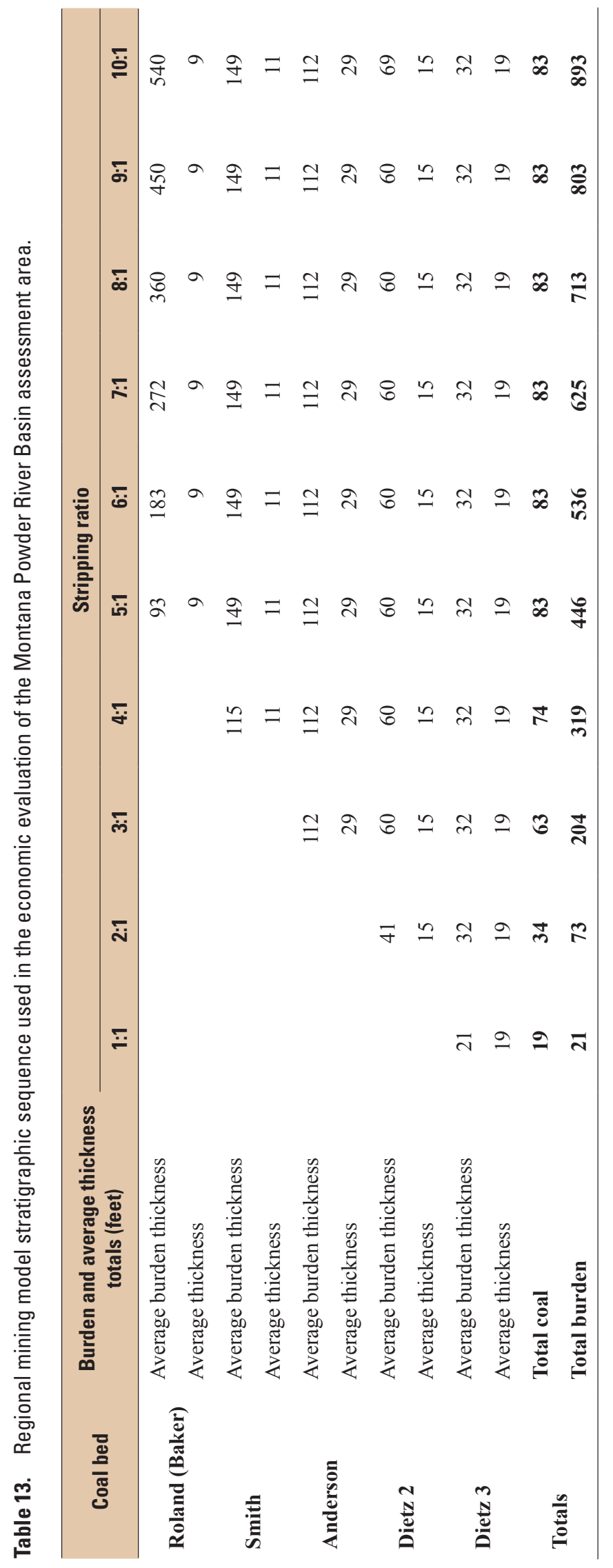

morphology and coal thickness. A comparison of the isopach map and stripping ratio map for a given bed illustrates this relation. For example, the more extensive area of less than a 10:1 ratio in R. 39 E. to R. 41 E. for the Werner/Cook bed (fig. 10) corresponds to the thickest portion of the Werner/ Cook bed (fig. 54). Elsewhere, the less than 10:1 ratio areas for the thinner portions of the Werner/Cook bed are confined to narrow bands along drainages.

\section{Surface Mine Model Design}

The surface mine model is based on a minimal level of project definition, which is indicative of a pre-feasibility level of cost estimation. Thicknesses of overburden, coal, and interburden are known through geologic modeling of the basin resources. Variations in coal quality, minor disruptions in continuity, groundwater characteristics, and overburden characteristics, among other localized factors, are less well known. The surface mine model represents a simplified multiple coal-bed sequence that is continuously excavated in a top-to-bottom and lengthwise configuration at an overall rate that attains an annual rate of coal production. All strata are assumed to be near horizontal in this mine model.

\section{Stripping and Coal Mining}

The surface mine model includes an elongated strip pit with highwall, spoil piles, and multiple coal beds. Overburden is drilled and blasted before loading and is deposited in spoil piles. The top of the coal is cleared of remaining overburden debris and is ripped and stockpiled for loading. Stockpiled coal in the pit is hauled to a dump facility in the mine plant area.

Equipment for overburden and interburden stripping and coal loading and hauling is sized for a 10-millionshort-ton-per-year coal mining operation lasting 20 years, which is consistent with previous assessments in the PRB. Shovel loading and rear dump-truck haulage is used to provide a common basis for the comparative modeling results produced in this assessment. Stripping shovels are sized for operating 24 hours per day and 365 days per year, and coal-loading shovels are designed for operating 20 hours per day and 350 days per year. An equipment availability of 89 percent is applied to both functions, whereas stripping is allowed 95 percent equipment use, and coal loading 85 percent equipment use. Stripping and coal loading shovels range from 15 to 60 cubic yards in bucket capacity, and the production rate of each unit yields 10 million tons of coal annually. Mining support equipment is included for haul-road maintenance, night illumination, in-pit water handling, and transportation for production supervisors and associated personnel. The total mining and direct support equipment cost is estimated at $\$ 62.7$ million for the $1: 1$ stripping ratio case and $\$ 206.5$ million for the 10:1 stripping ratio case. 
Calculations for the Rosebud/Knobloch single coal bed are greatly simplified. Only a single overburden and a single coal bed are considered whereas the removal of each burden and coal stratum in the multiple coal bed sequence must be at individual rates that provide for the overall removal at the predetermined production rate of 10 million tons per year in this assessment.

\section{Mine Plant Facilities}

The mine plant contains those facilities essential for supporting mining, such as buildings, coal-handling equipment and structures, truck dump facility, rail-loading facilities, and mobile and stationary equipment. The mine model contains several functions, such as providing for administration building, change house, maintenance shop, warehouse, laboratory building, emergency building, utility building, guard house and tool sheds.

This assessment includes several mining cases (stripping ratios of 1:1 to 10:1) for which different space requirements are anticipated, and the buildings are sized accordingly. Coal handling at the mine plant includes truck scales, inclined and horizontal belt conveyors, stacking tubes, scalping screen, coal breaker, coal silo, belt sampler, belt scales, railcar mover, and associated equipment. The mine plant also includes multiple elevated steel structures, enclosures, and concrete foundations. Preliminary designs for a truck dump to accommodate a wide range of large rear-dump truck capacities and a railroad loop were prepared, from which unit costing was performed. The typical model mine plant cost of \$20 million was calculated for all case studies, which included estimated costs for the following items:

- \$5 million for land improvements

- \$1 million for buildings

- \$5 million for coal handling equipment and structures

- \$1 million for truck dump

- \$2 million for railroad loop and access

- \$2 million for miscellaneous structures

- $\$ 4$ million for mobile and stationary equipment

\section{Reclamation}

Reclamation is an additional ongoing function and a major costing center in the surface mine model. A fleet of earthmoving and farm-type equipment perform a variety of activities from removal of brush and topsoil through contouring spoil piles, seed bed preparation, and planting.

\section{Supplies and Utilities}

Additional costing items in the surface mine model include equipment operating items, personnel wages, supplies (explosives, mulch, and seed) and utilities (electricity and natural gas/propane). The total annual operating cost is estimated at $\$ 54$ million for the 1:1 strip ratio case and $\$ 247$ million for the 10:1 case.

\section{Underground Mine Model Design}

Thick, deep, coal beds throughout the MTPRB provide potential mining targets for which surface mining may not be economic. No underground mines are operating in the PRB as discussed in the NWPRB assessment area (Scott and others, 2010) and the SWPRB assessment area (Osmonson and others, 2011). For each assessment, a separate underground mine model was developed; the NWPRB model was based on a production rate of 11 MST per year, and the SWPRB assessment area model was based on a production rate of $6 \mathrm{MST}$ per year. The SWPRB assessment expanded the scope of the NWPRB assessment by considering the effects of thickness and depth. This assessment further refines economic analysis of the MTPRB assessment area by including potential overall coal recovery with thickness and depth.

The preliminary underground mine model provides a reasonable estimate of the economic tipping point where underground mining might be a more viable alternative to surface mining, which, in turn, establishes a limit on recoverable resources by surface mining.

Potential underground coal reserves in the MTPRB assessment area were evaluated using a conventional, single pass, continuous, longwall methodology. Face shearer and roof support design are available for mining a bed up to $20 \mathrm{ft}$ thick, which is not an uncommon thickness in portions of the PRB. A mining model that was developed for the SWPRB assessment area was used in the MTPRB assessment area to determine potential reserves.

\section{Mine Layout Design}

The underground mine model incorporates longwall technology that includes four distinct primary components: surface mine plant, underground mine plant, development excavation, and longwall panel. All openings, support pillars, and longwall panel dimensions are sized to provide an annual production level of about 6 MST of coal per year, which is an average size for operating longwall mines. This average annual production is acquired through development, production, and pillar recovery operations. The model can be used to evaluate mining thicknesses that vary from 8-20 ft and depths from $500 \mathrm{ft}$ to as much as $3,000 \mathrm{ft}$. The model can also be used to evaluate a wide range of annual production rates with some adjustment to longwall panel access openings and pillar sizes.

The mining model was designed for primary entry to the longwall panel through five parallel main drifts. Additional excavation included a three entry headgate for incoming airway and main access to longwall mining, and two entry tailgates for return airway and supplies. Both the headgate and tailgate openings extend perpendicular from the main entries to the full panel length and are separated by the width of the 
longwall panel. An initial longwall face opening is excavated at the far end of the longwall panel that connects the headgate and tailgate. Excavation dimensions for the mining model are shown in table 14.

All mains, headgate, and tailgate entries are $10-\mathrm{ft}$ high in the base case. Opening widths are $24 \mathrm{ft}$ for the mains, $18 \mathrm{ft}$ for the headgate, and $16 \mathrm{ft}$ for the tailgate. Crosscuts are $18-\mathrm{ft}$ wide for the mains and headgate and $16-\mathrm{ft}$ wide for the tailgate. Pillars in the mains are $65 \mathrm{ft}$ by $85 \mathrm{ft}$ and the chain pillars in the headgate and tailgate are $65 \mathrm{ft}$ by $160 \mathrm{ft}$. The panel barrier pillar varies from 160 to $300 \mathrm{ft}$ wide depending on mining height and depth. Only the panel barrier pillar is adjusted for depth. Other pillars in the panel development have been oversized. A panel width of $1,000 \mathrm{ft}$ is used for coal having a 10 -ft-mining height and $500 \mathrm{ft}$ for a 20 -ft-mining height.

Annual production for the underground mine model is the sum of coal mined from main access, headgate, and tailgate excavation, longwall production; and pillar recovery. Physical dimensions of the longwall panel and associated mine openings are adjusted to maintain 6 MST of production per year. The effects of increased mining height and depth have been correlated with variable panel barrier-pillar size and overall pillar recovery. The longwall panel width varies only with mining height; the panel length is adjusted to provide the overall annual production from entries, panel, and pillars.

\section{Surface Mine Plant}

Coal handling facilities are the primary purpose of the surface mine plant. The surface mine plant for the underground mine are those facilities essential for supporting mining, including buildings, coal handling equipment, rail loading facilities, and mobile and stationary equipment. The mine-model surface plant includes an administration building, change house, maintenance shop, warehouse, laboratory building, emergency building, utility building, guard house and tool sheds, and hoisting and ventilation facilities to support underground operations.

Other facilities include a stacking tube, horizontal and inclined belt conveyors, scalping screens, coal breaker, coal silo, waste bin, rail loadout structure, rail loop, various elevated steel structures and housings, preparation plant, and concrete foundations. The inclined belt conveyor is included with the surface mine plant whereas the excavation for the incline is included with the underground mine plant. All stationary coal handling facilities are oversized to move in excess of the 6 MST annual production rate.

Hoisting facilities are included in the surface mine plant and shaft excavation and furnishing are included in the underground mine plant component of the mine model. Hoisting facilities are detailed for a single, vertical, 24-ftdiameter men-and-materials shaft. The primary mine hoist is sized to lower and raise about 317 mining, mining support, and technical support personnel working on a two-shift-perday basis. The hoisting plant might typically include a $110-\mathrm{ft}$ high open steel headframe with a 12 -ft-diameter head sheave, a 10-ft-diameter double-drum, single-clutch hoist, 15/8-inchdiameter steel hoisting ropes, a 70-man-capacity double-deck mancage, and a 12-ton counterweight. An additional 80-inchdiameter emergency hoist with $3 / 4$-inch-diameter steel hoisting rope, head sheave, and escape capsule are included in the hoisting plant as well. One dedicated ventilation shaft is included in the mine plant but hoisting facilities for it are not provided.

Ventilation facilities include two $10 \mathrm{ft}$-diameter, 800-horsepower surface mine fans, ducting, concrete foundation, electrical controls and switchgear, and appropriate enclosures. These facilities are provided for a 24 -ft-diameter vertical shaft.

\section{Underground Mine Plant}

Three excavations (men-and-materials shaft, ventilation shaft, and ramp) connect surface and underground mine plants at the surface to the underground. A nominal depth of $1,000 \mathrm{ft}$ has been used for shafts and an inclined length of 2,280 ft for a ramp. Both shafts are excavated with large-diameter drilling equipment and lined with $2 \mathrm{ft}$ of concrete. Both shafts are equipped with wall brackets to support one 4-inch-diameter and one 8 -inch-diameter steel pipeline, one $15 \mathrm{kV} / 500 \mathrm{MCM}$ insulated electrical power cable, and a small communications

Table 14. Underground excavation dimensions in the longwall mining model for a 10 feet mining height.

\begin{tabular}{lcccc}
\hline & Number & Height (feet) & Width (feet) & Length (feet) \\
\hline Main entries & 5 & 10 & 24 & 1,945 \\
Main crosscuts & 94 & 10 & 18 & 85 \\
Headgate & 3 & 10 & 18 & 11,635 \\
Headgate crosscuts & 131 & 10 & 18 & 65 \\
Tailgate & 2 & 10 & 16 & 11,635 \\
Tailgate crosscuts & 66 & 10 & 16 & 65 \\
Longwall entry & 1 & 10 & 18 & 1,000 \\
\hline
\end{tabular}


cable. The men-and-materials shaft also includes steel buntons with landings, steel ladders, and timber mancage guides. The ramp is excavated with a continuous mining machine and lined with rock bolts, wire mesh, and shotcrete.

Primary excavations at the bottom of the underground mine plant at the men-and-materials shaft include a warehouse, shop, lunchroom, refuge chambers, water sump, electrical substation, and connecting runaround access way. The bottom of the ramp is located some distance away and has excavations for refuge chambers, electrical substation, and runabout access way. Both the shaft and ramp stations are lighted with 100-, $400-$, and 1,000-watt fixtures. Stationary equipment in the shaft station includes four $100 \mathrm{psi} / 490 \mathrm{cfm}$ air compressors and ten $500 \mathrm{gpm} / 200 \mathrm{ft}$ head centrifugal water pumps. Both the shaft and ramp stations include concrete flooring, steel equipment bases, and $5 \mathrm{kV} / 4 / 0$ electrical cable distribution.

Fresh air provided by surface fans supplies the secondary air distribution using 36-inch-diameter, rigid ventilation ducts, which are boosted with 14,000 cfm ventilation fans. This secondary system is used throughout the underground mine.

\section{Development Excavation}

Underground excavation that extends some distance beyond the shaft and ramp stations is completed prior to production mining as described for the production unit section of this assessment and is performed as a construction activity. Coal removed during this project phase is transported to the surface and disposed as a waste product.

Development excavation includes five parallel headings with connecting crosscut openings. These headings extend approximately $1,300 \mathrm{ft}$ to the edge of the mine plant barrier pillar. This barrier pillar is sufficiently sized in order for underground mine plant facilities to be protected from structural instability because of mining production. About 15,000 ft of equivalent primary openings are excavated during this phase, including $6,500 \mathrm{ft}$ of main access way, $6,800 \mathrm{ft}$ of crosscuts, and $1,700 \mathrm{ft}$ of other equivalent openings. All excavation during this phase is performed by a continuous miner and supporting mobile equipment.

\section{Production Unit}

The production unit is generally centered near the longwall panel. All pre-longwall mining following development excavation is considered production and not development. The production unit includes the main access way extending from the initial development excavation, gateway excavation, longwall opening, and longwall panel. The normalized production unit includes $1,836 \mathrm{ft}$ of main access-way development. Each opening is $24-\mathrm{ft}$ wide with 18 -ft-wide crosscuts located on $103-\mathrm{ft}$ center- lines. Five access-way headings are excavated on 109 -ft center-lines.

Gateway excavation starts at the main access way and extends to the full length of the longwall panel. A three-entry arrangement is developed for the headgate and two entries for the tailgate. Headgate openings are $18 \mathrm{ft}$ wide with 18 -ft-wide crosscut connections, which are placed on 178 -ft center lines. Tailgate openings are designed as 16 - $\mathrm{ft}$ openings with 16 -ftcrosscut connections on 176-ft center lines. A single longwall opening is excavated to connect the ends of the gateways. This opening is $18 \mathrm{ft}$ wide and exposes the initial longwall face. A longwall panel that is $1,000 \mathrm{ft}$ wide and $14,571 \mathrm{ft}$ long is included in the underground mine-model design. This panel size is estimated to provide sufficient coal for a continuous year of operation without moving to a new area. A complete suite of standard equipment is included in the model (face shearer, roof supports, armored face conveyor, and supporting systems).

\section{Pillar Recovery}

Pillar recovery provides substantial coal production as a final activity in the typical production unit. This operation involves enough removal of a single pillar mass to provide a sufficient amount of coal production without collapsing the immediate roof area during the activity. Pillar recovery is included in the underground coal mining model for chain pillars, panel barrier, and main access pillars for the typical longwall unit.

High vertical stresses are applied to the lateral edges of the longwall panel as the shearer cuts across the face of the longwall and progresses toward the end of the panel. These stresses tend to concentrate over the rib line of the opening adjacent to the panel. The forward edge of the first row of support pillars in the gateways on either side of the panel, are expected to partially collapse. This collapse is likely to cause a yield zone that extends some distance into the pillar interior. The remaining portion of the pillar not collapsed is expected to be competent enough to allow significant recovery by a continuous miner. The vertical stress concentration over the outer pillar line in the headgate should be less than the stress over the longwall panel periphery, and a higher pillar extraction rate can be expected.

All the material on the panel side of the barrier pillar is expected to be coal waste. Pillar recovery will need to be conducted from the main access way. Excavation of the barrier pillar will be conducted together with main access-way pillar recovery. Recovery will be partial, in order to leave sufficient natural support for retreating from the area.

\section{Surface Mine Model Economic Evaluation}

Economic analysis was performed on near-surface coal resources as shown in table 10 to determine the reserve potential in the MTPRB assessment area. The surface mine model was used to demonstrate how coal delineated in the generalized model in table 10 can be mined. The surface mine model has also been used to calculate the breakeven cost per ton, which is the total mining cost divided by the total number of tons mined. A cost estimate for mining that is below the breakeven cost is potentially profitable, and a 
mining cost above the breakeven cost is not. The breakeven cost is calculated from the total expenditures for a 20 -year time period. A net present value analysis based on discounted capital and operating expenditures is used to calculate the breakeven cost, as explained in the Net Present Value and discounted Cash Flow Rate of Return Analyses section of this report.

Preliminary economic modeling of single seam scenarios indicated results that were closely similar to that of the regional mining model. Therefore, the breakeven costs in table 10 for the regional mining model were also applied to the single bed models. This simplification facilitated the reserve analysis by requiring the development of only one cost curve.

\section{Net Present Value and Discounted Cash Flow Rate of Return Analyses}

Discounted Cash Flow Rate of Return (DCFROR) is most commonly used in industry to determine the profitability of an investment. Cash flow (the difference between price and cost or income and investment) is calculated for each economic period throughout a project life. For a coal-minemodel economic evaluation, cash flows are determined for each year of a 20 -year mine life. The present values of these cash flows are calculated for both the surface and underground mine models. Future values may also be calculated without any apparent advantage but present value analysis is the convention adopted for this assessment. As relatively large expenditures are incurred throughout a typical mine life, the effect of these expenditures directly affect the overall mine cost by the value of those expenditures in terms of current or present dollar values. A dollar spent tomorrow is assumed to be less in value than one spent today. The future expenditures are, thereby, discounted to 2012 dollar values. DCFROR calculations include the original cost to bring a mine into operation, discounted expenditures made during the mine life, discounted cash flows for each productive year, and the salvage cost at the end of the project. Known parameters in DCFROR calculations are expenditures for capital items, ongoing costs to produce coal, an interest rate, and the mine life. The rate of return, which is unknown and determined by the calculation, is the measure of profitability.

DCFROR calculations may include either constant or escalated dollar values but not both. Escalated dollar values were used for the economic evaluations. Equipment, various major supply items, and utilities are known to increase and decrease in cost at different rates with time. Escalated or current dollar values are actual revenues or costs that will be incurred at specific points in time and more applicable with the method of analysis used for the coal mine model.

Net Present Value (NPV) analysis is used in determining the potential reserves for the MTPRB, as income (sales price times tons mined) is not known or fixed. An arbitrary interest rate of 8 percent is used as the annual compounding rate (T.K. Lee, written commun., 2004) for a 20 -year time period. NPV analysis provides a means by which a profit or loss sales price (equivalent to the breakeven cost) can be determined. This calculation is possible as the rate of return in the DCFROR calculation is set at zero and all capital expenditures and income from salvage are discounted to present values; the net present value is the sum of these discounted amounts. The capital cost NPV is set equal to the unknown cash flow NPV, so that overall capital cost is equal to the overall cash flow. The calculated tax is removed from the NPV cash flow and the NPV operating costs are added to produce the desired income to pay for all the expense and yield a desired rate of return ( 8 percent).

\section{Capital Cost}

The purchase and replacement costs for capital items are determined for each stripping ratio case. Capital items include mining and process equipment; engineering, laboratory, and other technical equipment; light and medium trucks; land improvements; buildings; reclamation; and other mobile and stationary equipment.

The total direct capital investment for equipment and facilities is applied as a single expense at the initial point in time (project year 0), which for this evaluation is calendar year 2011. Additional capital investments are made during the $5^{\text {th }}, 7^{\text {th }}, 10^{\text {th }}$, and $14^{\text {th }}$ year for a 15 -year project life to replace obsolete and worn-out equipment. Additional multiples of 5, 7, and 10-year equipment replacements are added as appropriate for project or mine lives extending to 20 -year duration. Capital reinvestment is generally performed for equipment as certain land improvements are not replaced until the $15^{\text {th }}$ year, and buildings continue service for the life of the mine.

Salvage value has been determined for this economic evaluation. Salvage adds income as the unused value of a capital asset less a market adjustment is deducted from the NPV of capital expenditure. The value of salvage is generally discounted in overview calculations such as this, because of to its lessened effect for long project lives. A dollar spent and returned today will be worth a dollar, whereas it will only have a value of $21 \phi$ after 20 years (calculated at 8 percent interest rate).

Capital depreciation is determined by placing appropriate costs in the class life designations specified for tax calculations that are based on Internal Revenue Service (IRS) guidelines as set forth in Publication 946 of the Department of the Treasury (2008). The tax class life designations are $3,5,7,15,20$, and 39 years for mining-related activities. Depreciation options are available. Capital items are depreciated as quickly as possible in this evaluation. The first three designations (costs specified for 3, 5, and 7 years) are depreciated using the 200 percent declining balance method. Other class life designations use a 150 percent declining balance method for 15 and 20 years and straight-line method for 39 years. Annual depreciation amounts for each of the class life designations are calculated using standard percentages provided in the Modified Accelerated Cost Recovery System 
(MACRS) General Depreciation System (GDS) for each year of the 20-year mine life (Department of the Treasury, 2008). The depreciable amount for each year of the project life is discounted to a net present value.

Other initial expenditures are made for capital items that do not fall within the direct capital cost category. These are indirect capital costs. These initial expenditures can include lease acquisition, engineering, home office overhead when applicable, licenses, fees, patents, and miscellaneous items. Both tangible and non-tangible items may be included. Tangible indirect costs are depreciable and non-tangible items are amortized in accordance with IRS guidelines (Department of the Treasury, 2008). An amount of 8 percent of direct capital costs has been included in this evaluation; amortization and working capital are excluded.

\section{Operating Cost}

Operating costs including personnel, equipment maintenance and fluids, supplies, and utilities are calculated as annual expenses. Supplies include explosive and accessory use in stripping, and seed mixture in reclamation. Utilities include the local power charge for electricity and natural gas/propane for heating buildings.

\section{Breakeven Cost Determination}

Breakeven cost calculation is performed upon the total capital cost discounted to present value as previously described, depreciation, and operating costs to yield the required income to produce these values. This income, which is determined at net present value, is divided by the total calculated production throughout the mine life to give the average cost per ton or the pivot point for potential profitability. This breakeven cost per ton has been calculated for stripping ratio cases from 1:1 to 10:1 as shown in table 10 . 


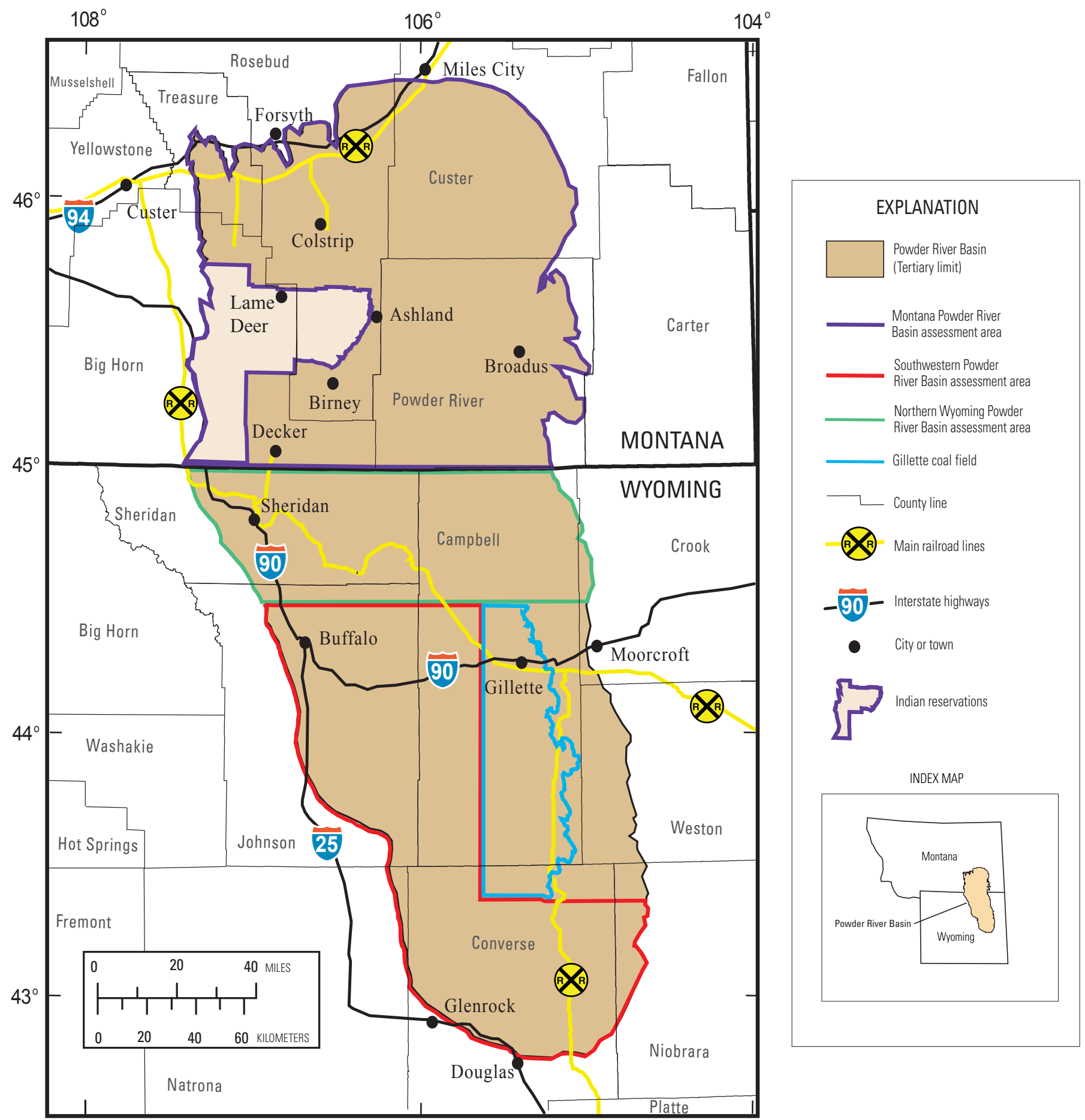

Figure 1. Locations of the Montana Powder River Basin assessment area, Montana, Northern Wyoming Powder River Basin assessment area, Wyoming, (Scott and others, 2010), Southwestern Powder River Basin assessment area, Wyoming, (Osmonson and others, 2011), and the Gillette coal field, Wyoming (Luppens and others, 2008). 


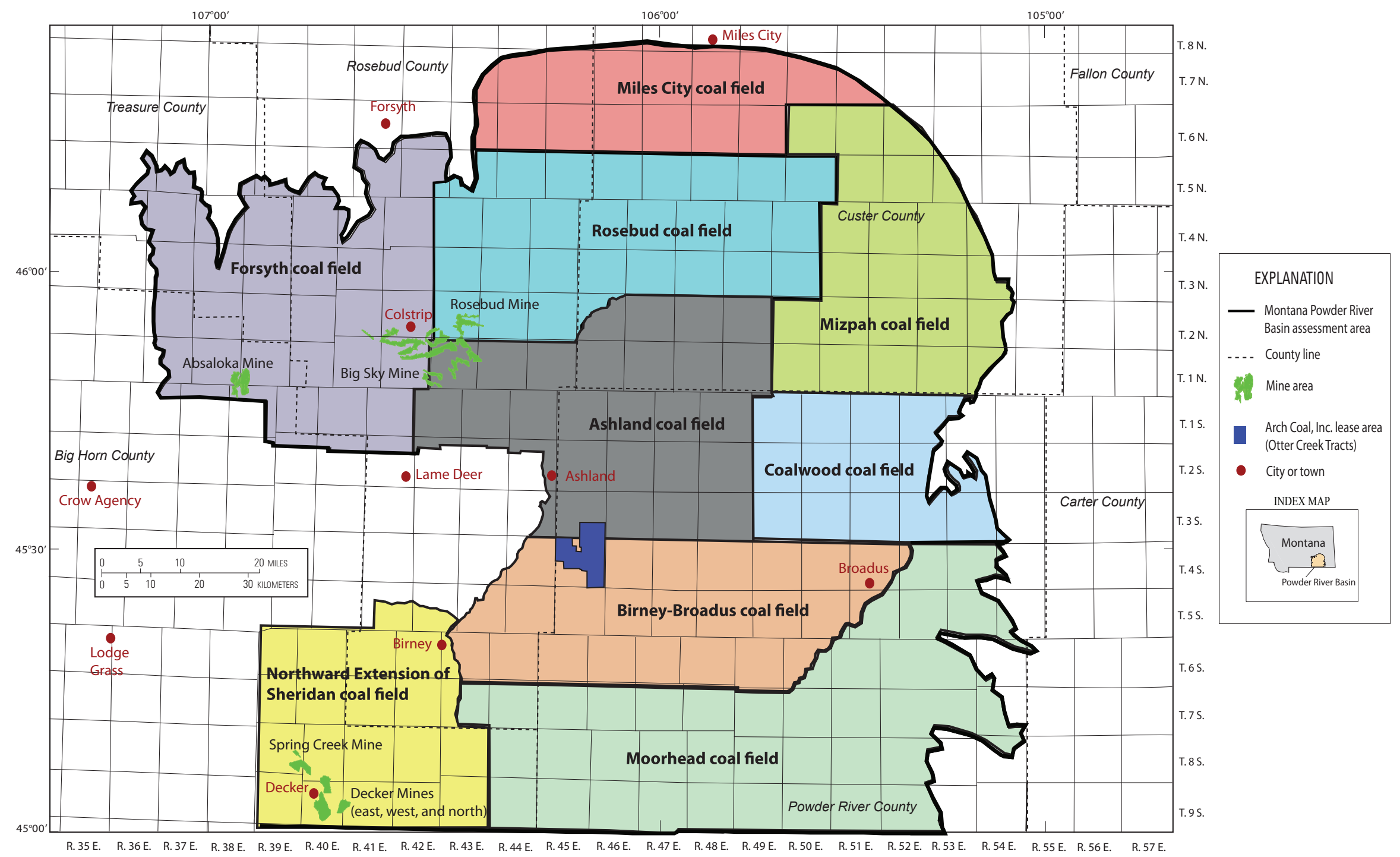

Figure 2. Map showing coal fields, mines, and lease areas in the Montana Powder River Basin assessment area. (Modifed from Averitt, 1966, and McLellan and others, 1990). 


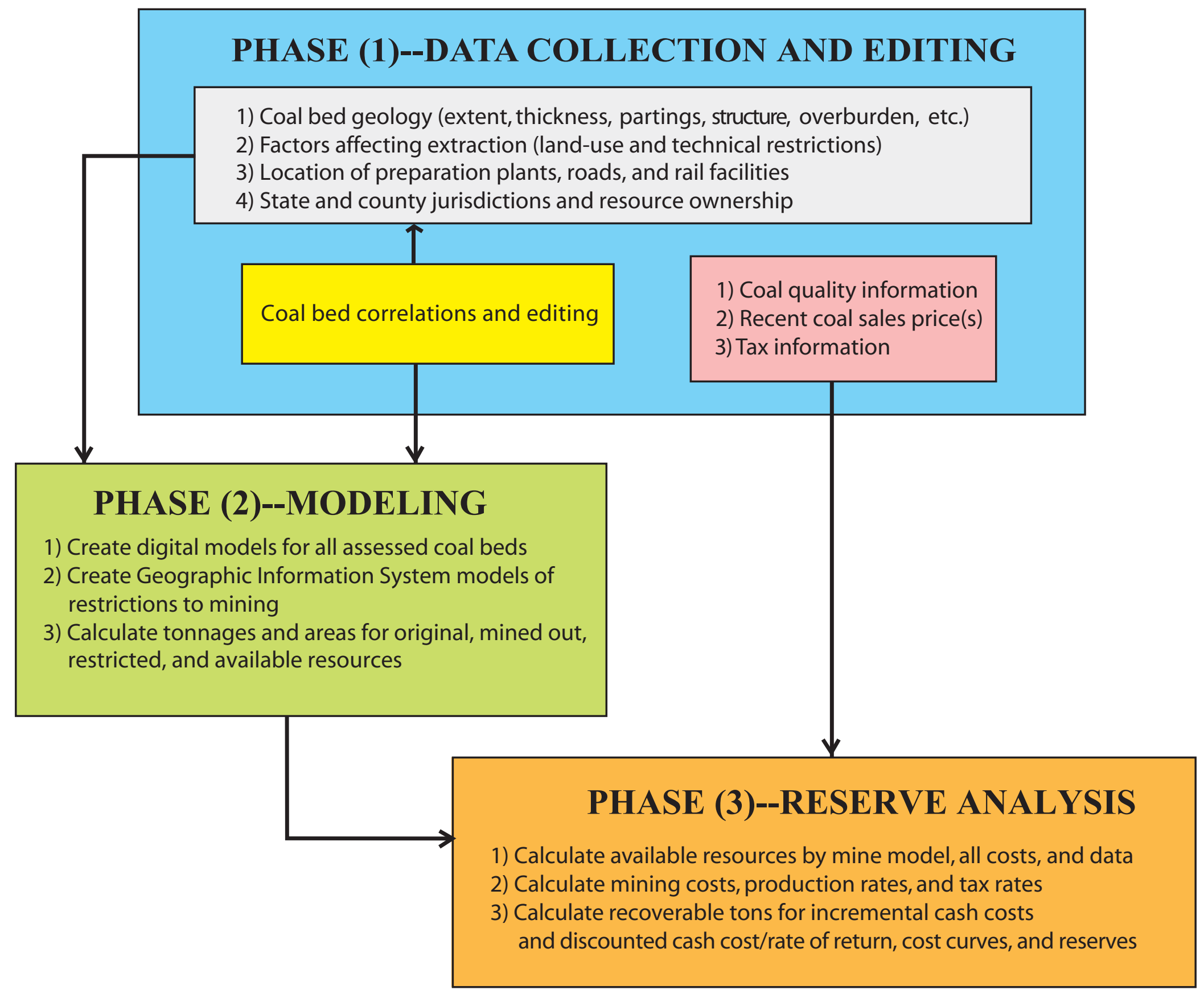

Figure 3. Flow chart showing generalized methodology used for coal resource and reserve evaluation. 


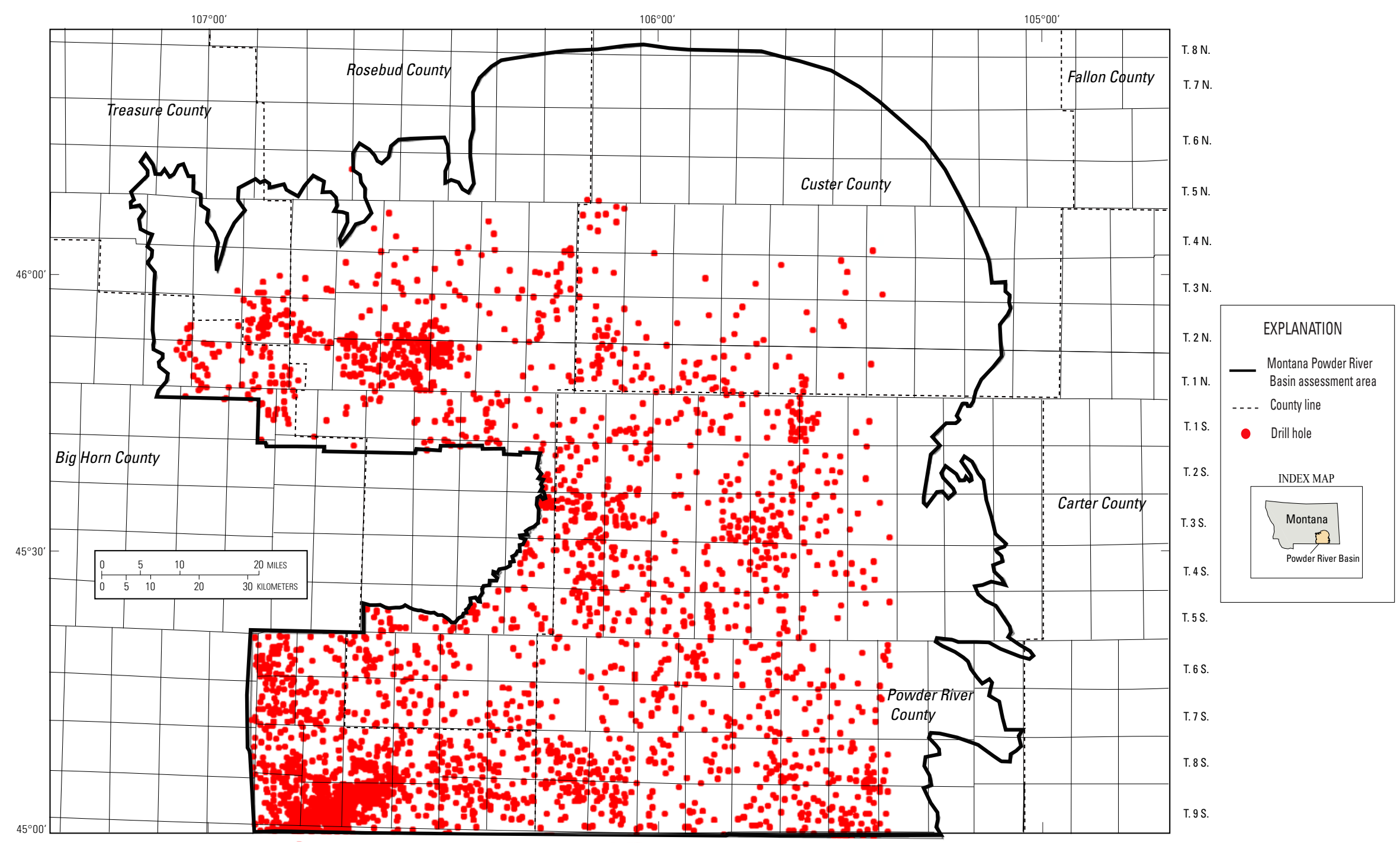

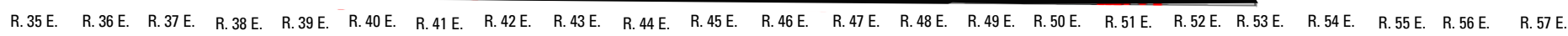




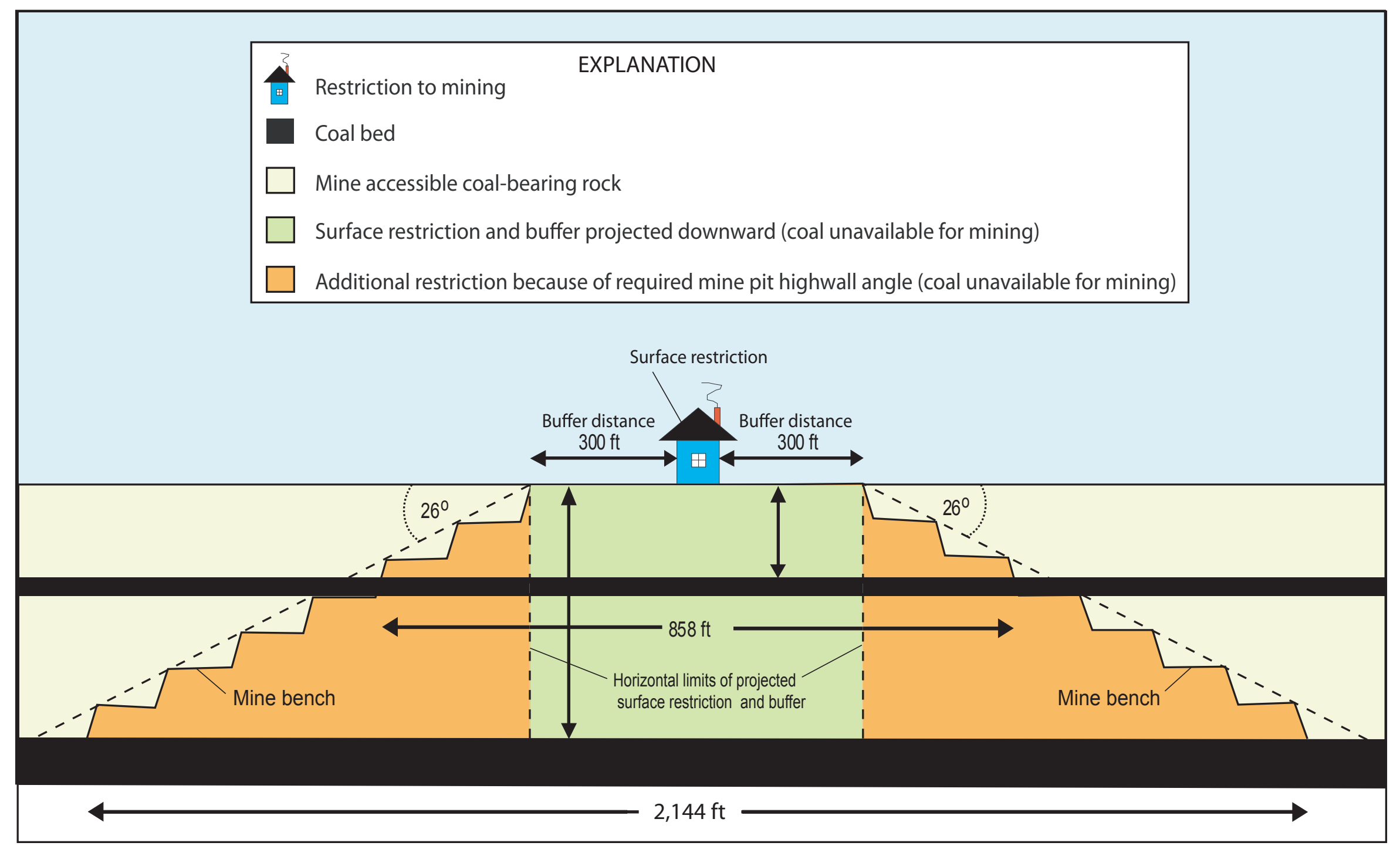

Figure 5. Illustration showing the effect of coal bed depth upon restricted resource due to mine-pit highwall setback requirements (not to scale). 


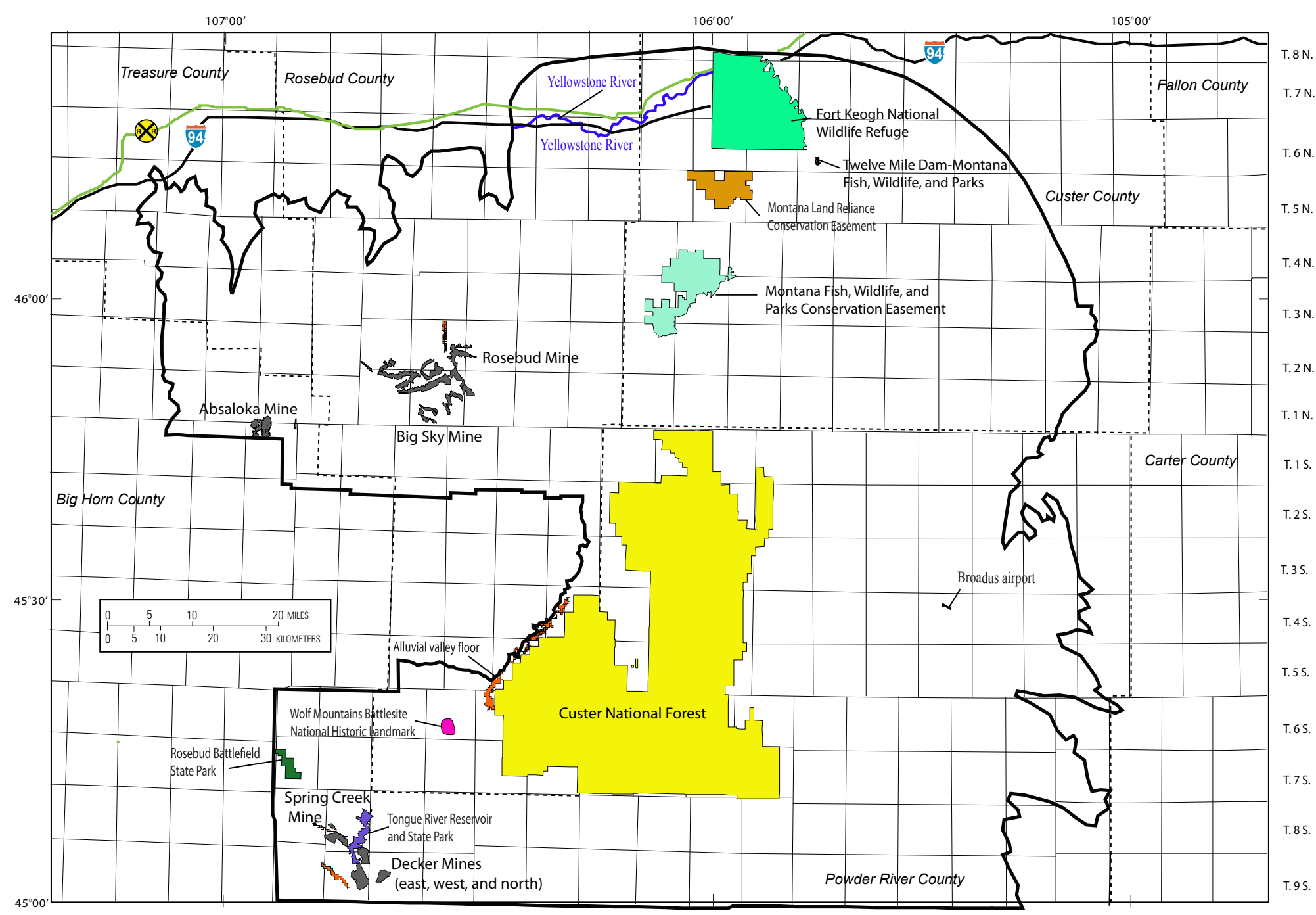

\section{EXPLANATION}

- Montana Powder River

- Countyline

RESTRICTIONS

$-\overline{6}$ - In- Interstate

- Railroads

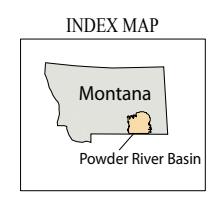

Figure 6. Map showing land-use restrictions in the Montana Powder River Basin assessment area. 


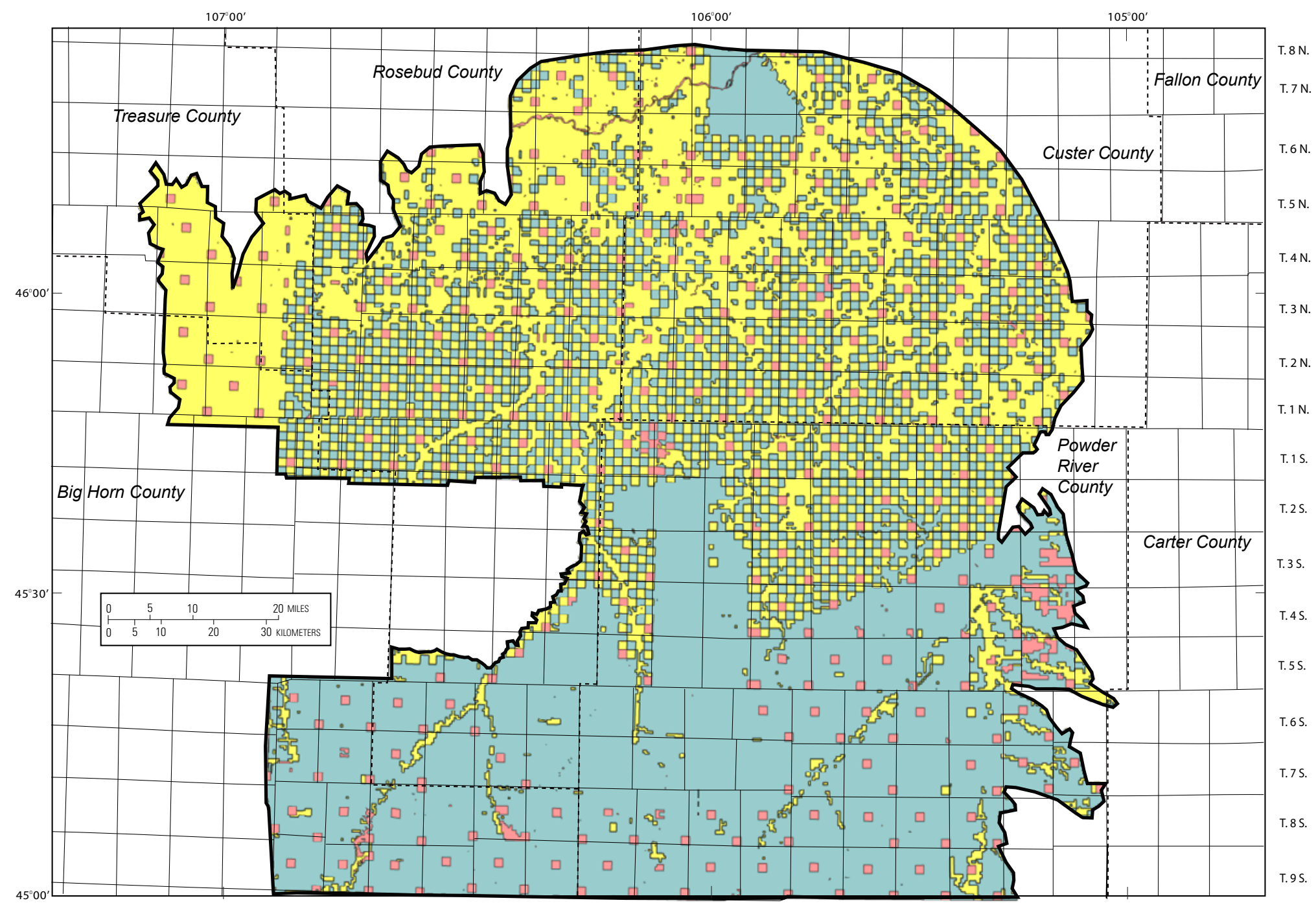

R. 35 E. R. 36 E. R. 37 E. R. 38 E. R. 39 E. R. 40 E. R. 41 E. R. R. 42 E. R. 43 E. R. 44 E. R. 45 E. R. 46 E. R. 47 E. R. 48 E. R. 49 E. R. R. 50 E. R. 51 E. R. R2 E. R. 53 E. R. 54 E. R. 55 E. R. 56 E. R. 57 E.

Figure 7. Map showing coal ownership in the Montana Powder River Basin assessment area. 

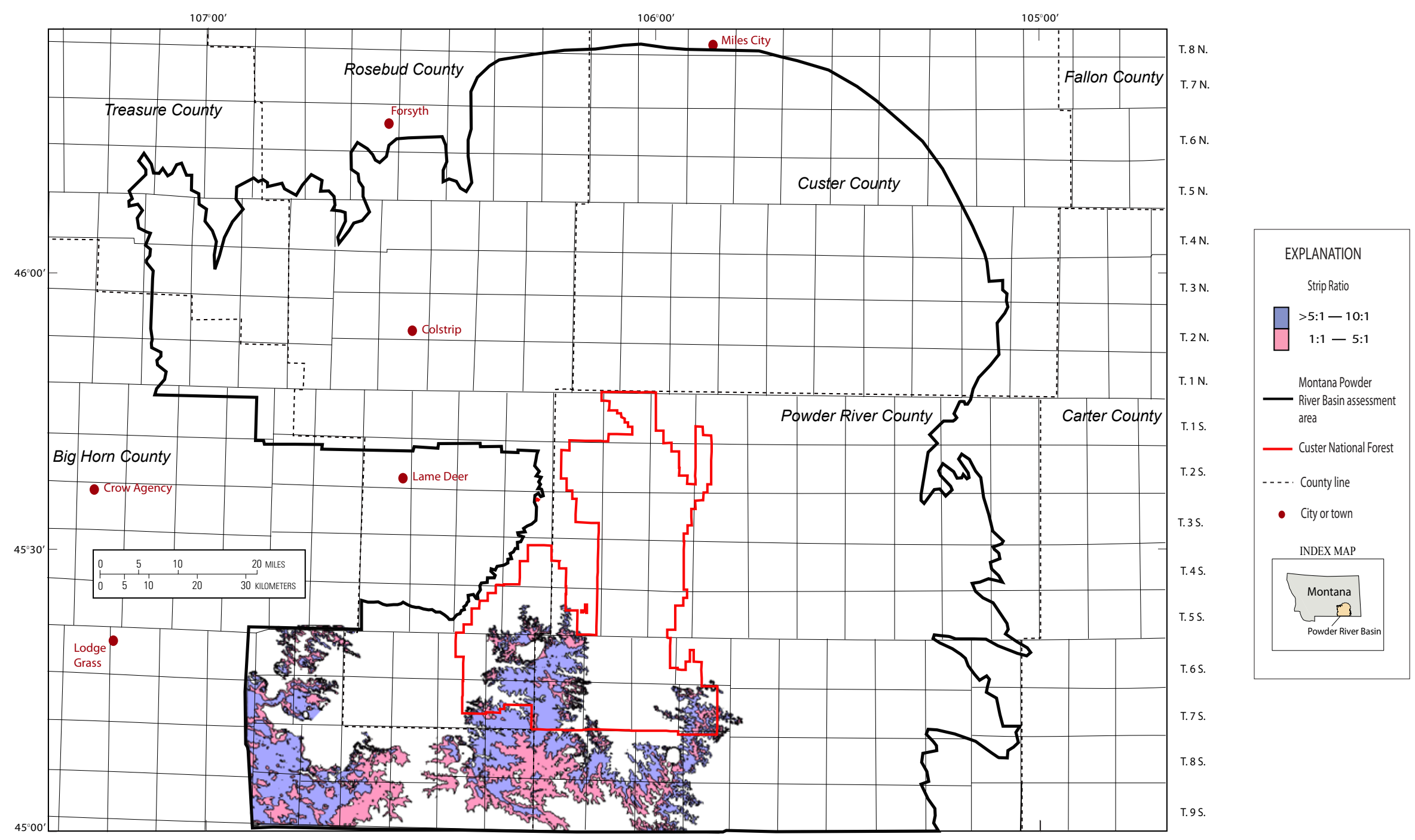

Figure 8. Areal extent for the Roland (Baker), Smith, Anderson, Dietz 2, and Dietz 3 coal beds where the stripping ratios are from 1:1 to 10:1, thicknesses are equal to at least 5.0 feet, and the overburden is less than or equal to 500 feet thick in the Montana Powder River Basin assessment area. 


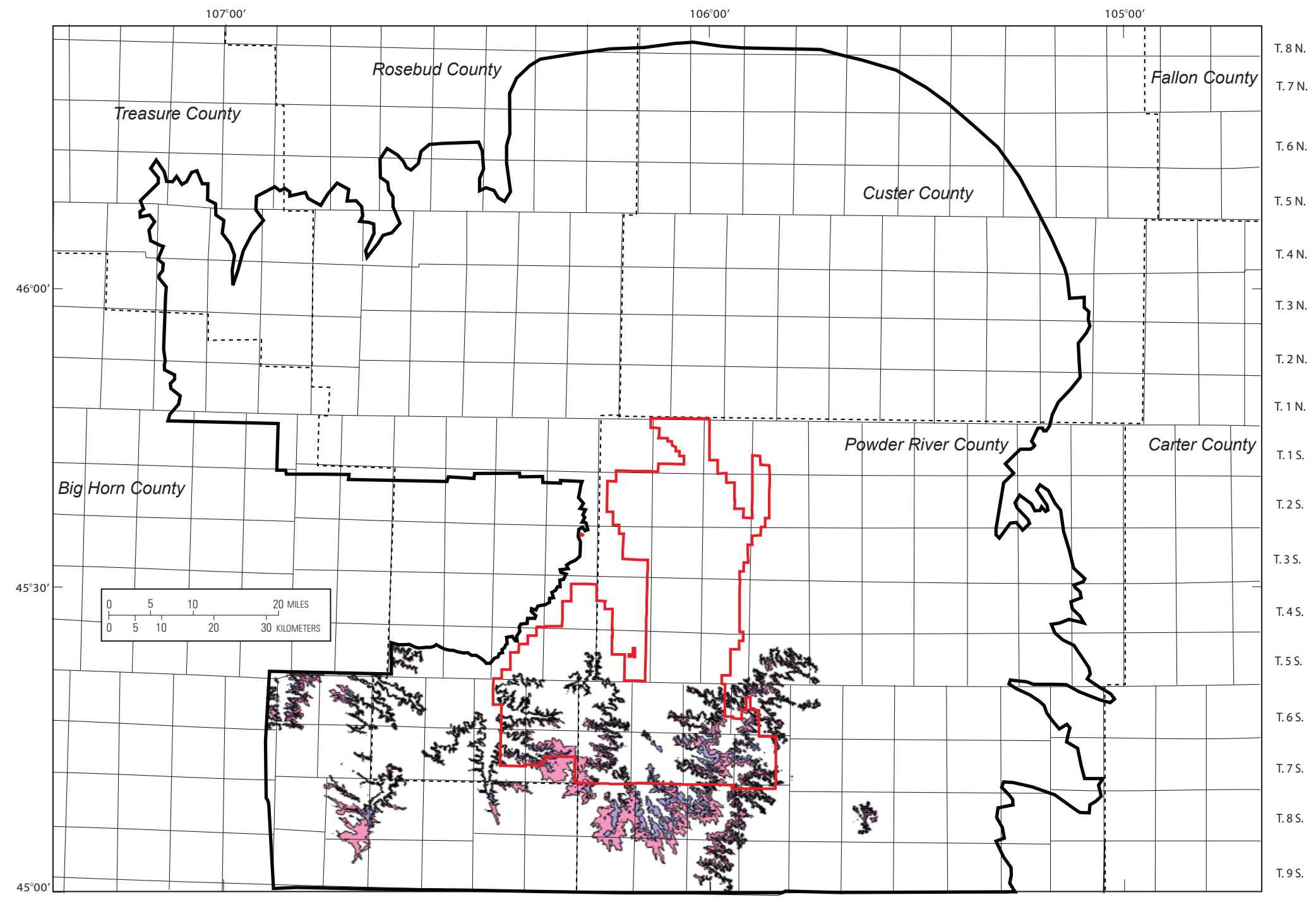

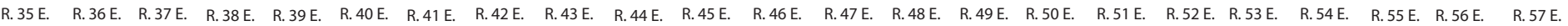

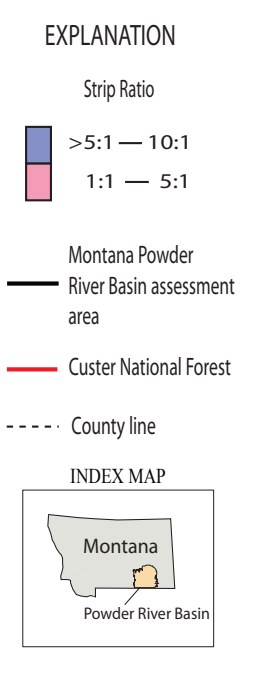

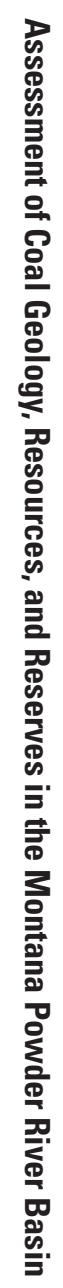

Figure 9. Areal extent for the Canyon coal bed where the stripping ratios are from 1:1 to 10:1, thicknesses are equal to at least 5.0 feet, and the overburden is less than or equal to 500 feet thick in the Montana Powder River Basin assessment area. 


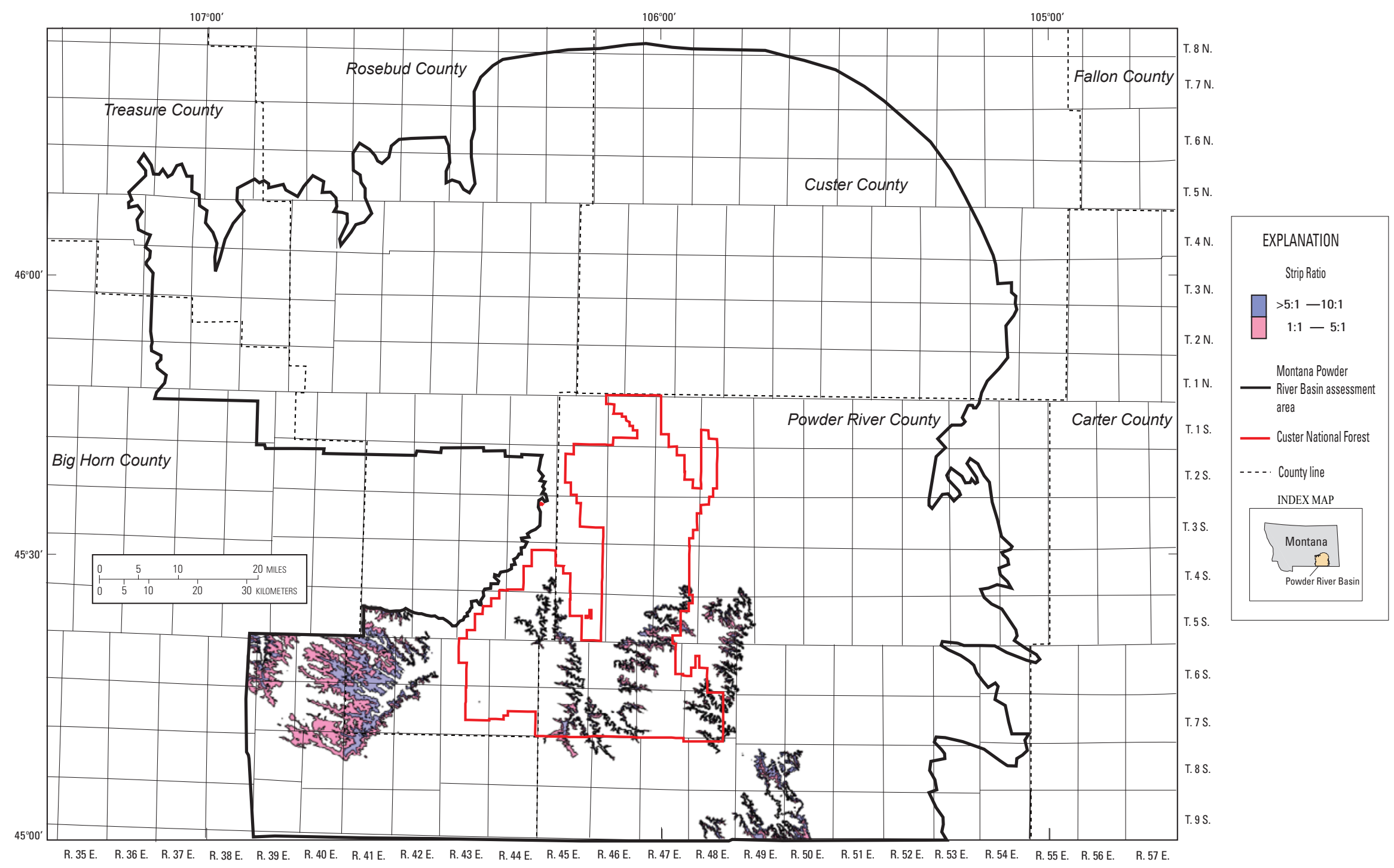

Figure 10. Areal extent for the Werner/Cook coal bed where the stripping ratios are from 1:1 to 10:1, thicknesses are equal to at least 5.0 feet, and the overburden is less than or equal to 500 feet thick in the Montana Powder River Basin assessment area. 


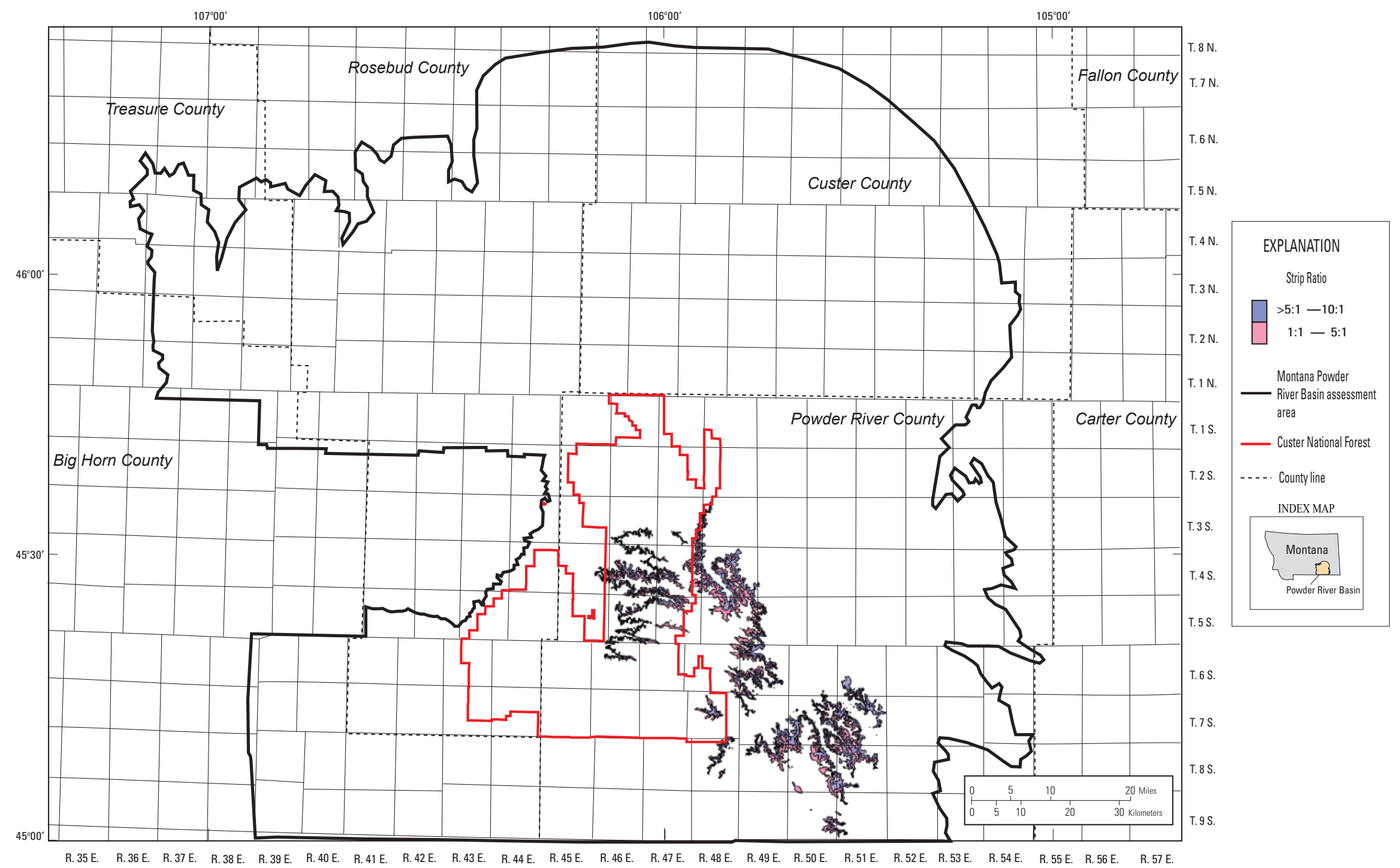

Figure 11. Areal extent for the Pawnee coal bed where the stripping ratios are from 1:1 to 10:1, thicknesses are equal to at least 5.0 feet, and the overburden is less than or equal to 500 feet thick in the Montana Powder River Basin assessment area. 


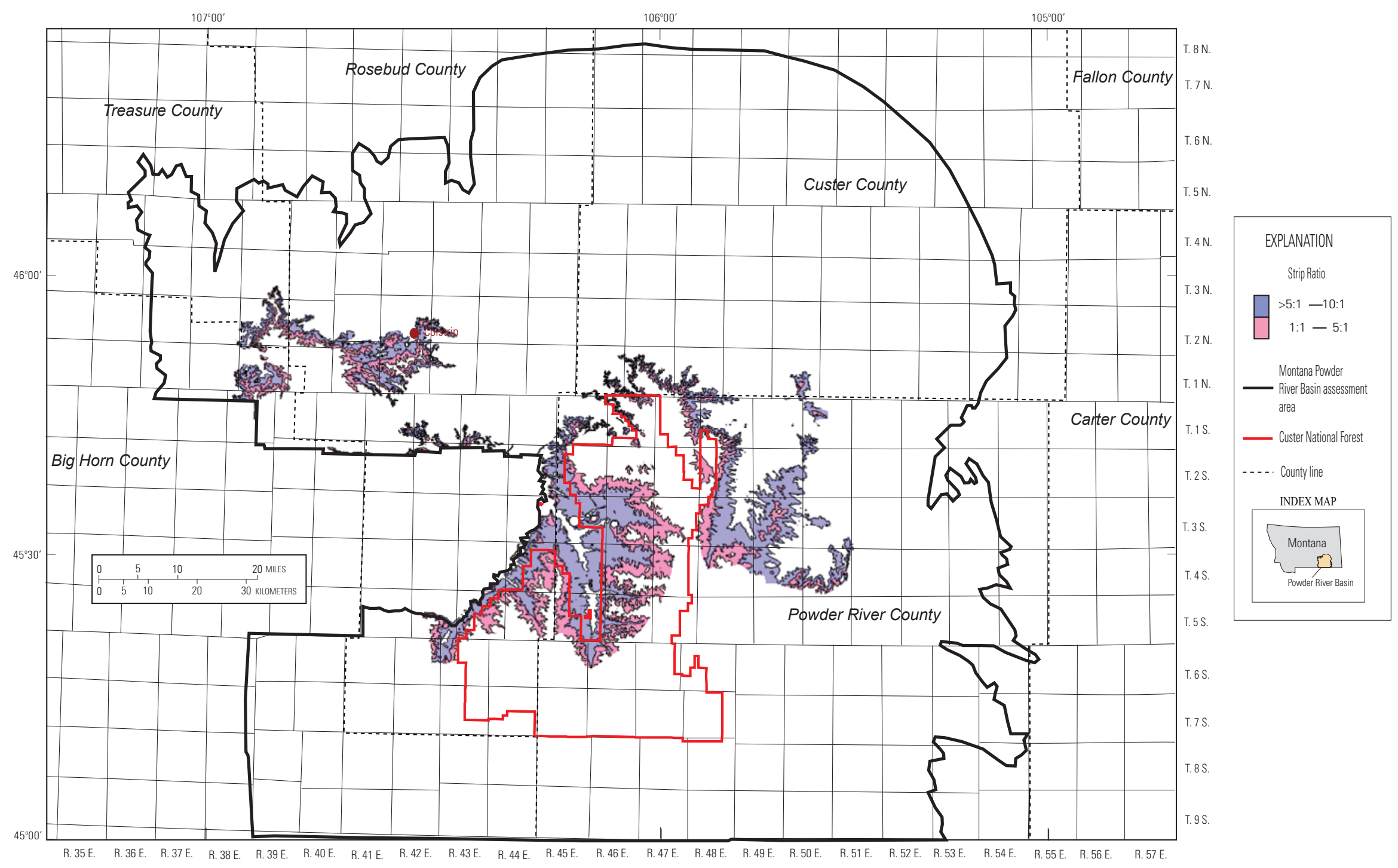

Figure 12. Areal extent for the Rosebud/Knobloch coal bed where the stripping ratios are from 1:1 to 10:1, thicknesses are equal to at least 5.0 feet, and the overburden is less than or equal to 500 feet thick in the Montana Powder River Basin assessment area. 


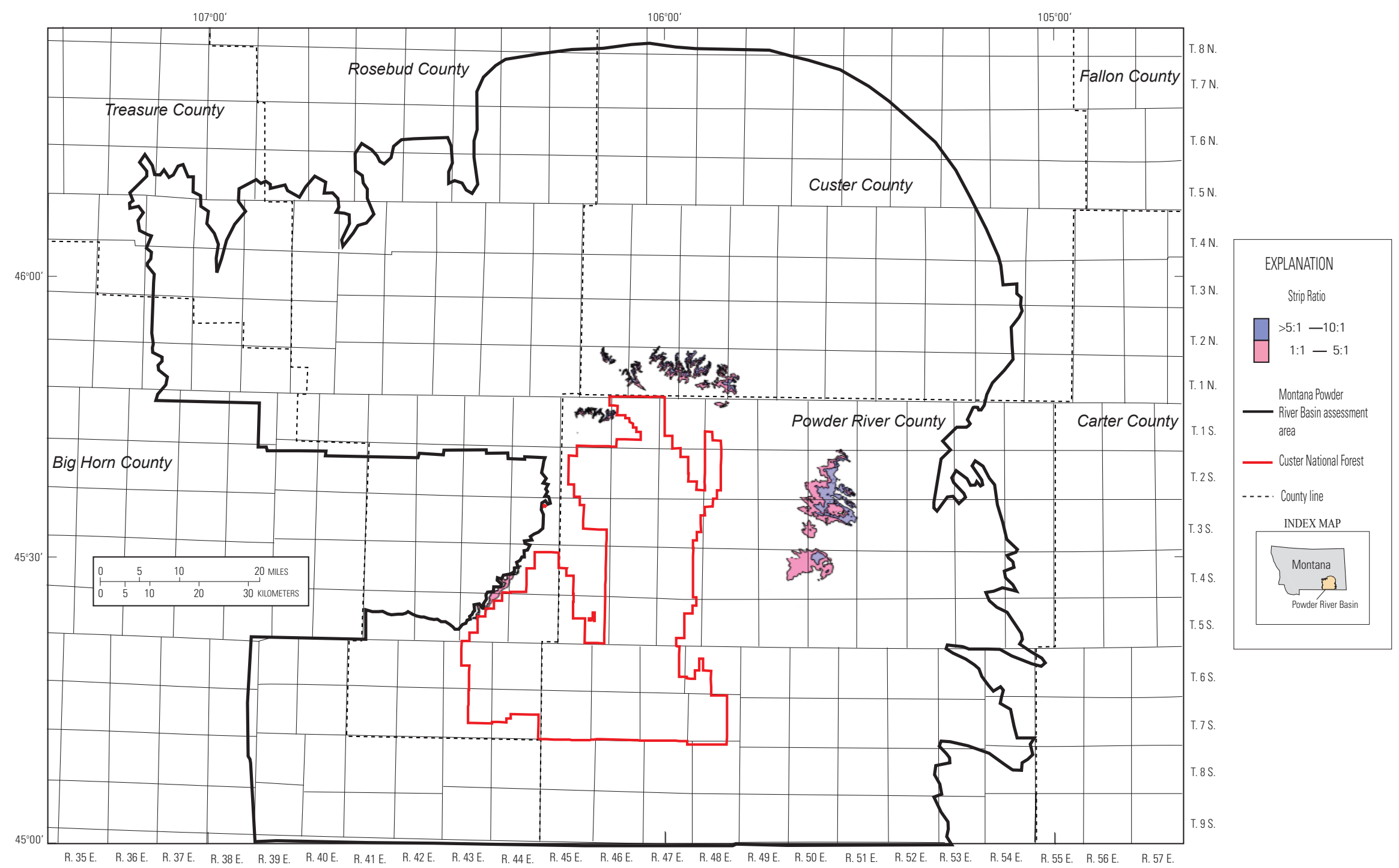

Figure 13. Areal extent for the Flowers-Goodale coal bed where the stripping ratios are from 1:1 to 10:1, thicknesses are equal to at least 5.0 feet, and the overburden is less than or equal to 500 feet thick in the Montana Powder River Basin assessment area. 


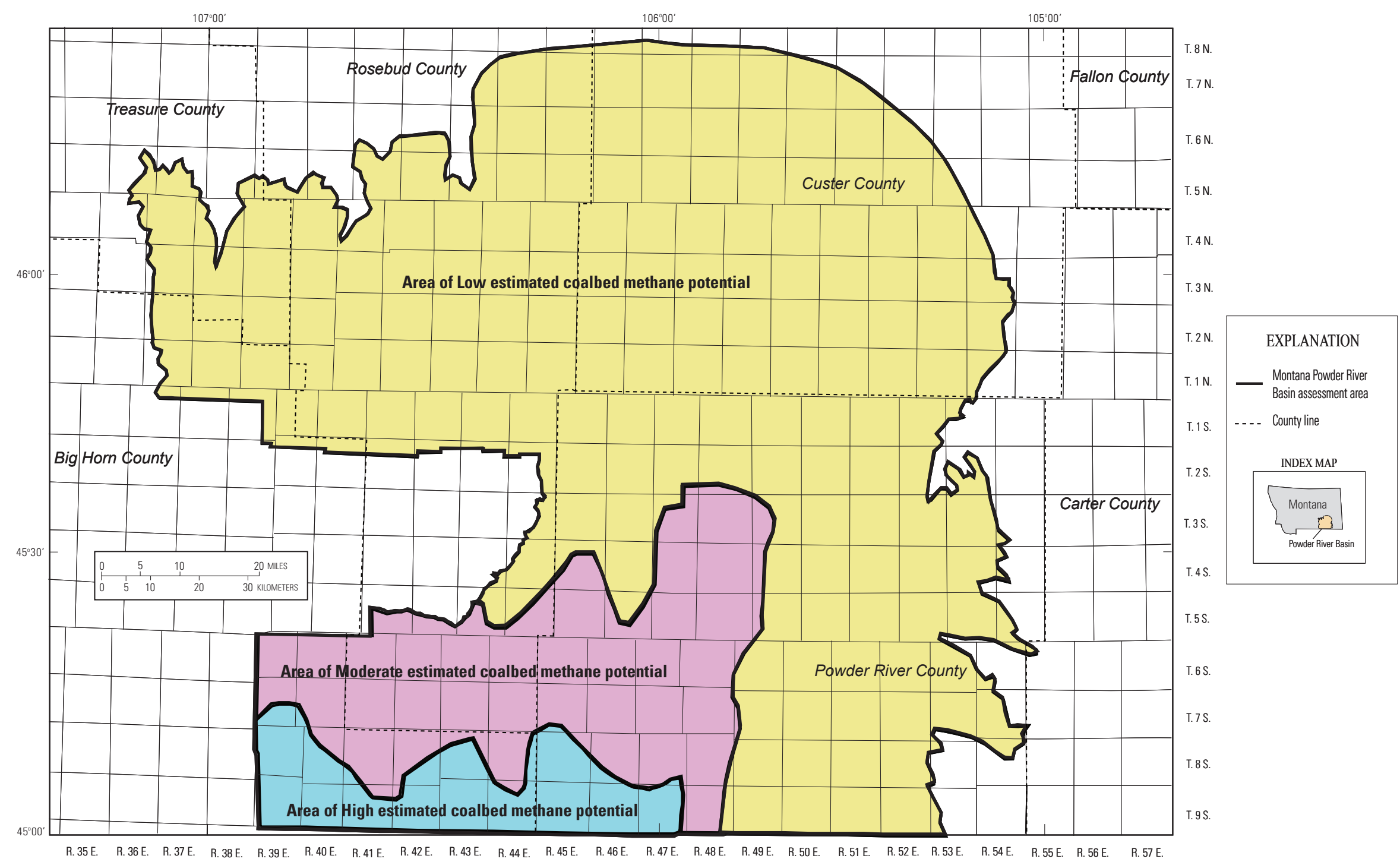

Figure 14. Map showing location of areas of low, moderate, and high coalbed methane potential in the Montana Powder River Basin assessment area (Van Vaast and Thale, 2001). 


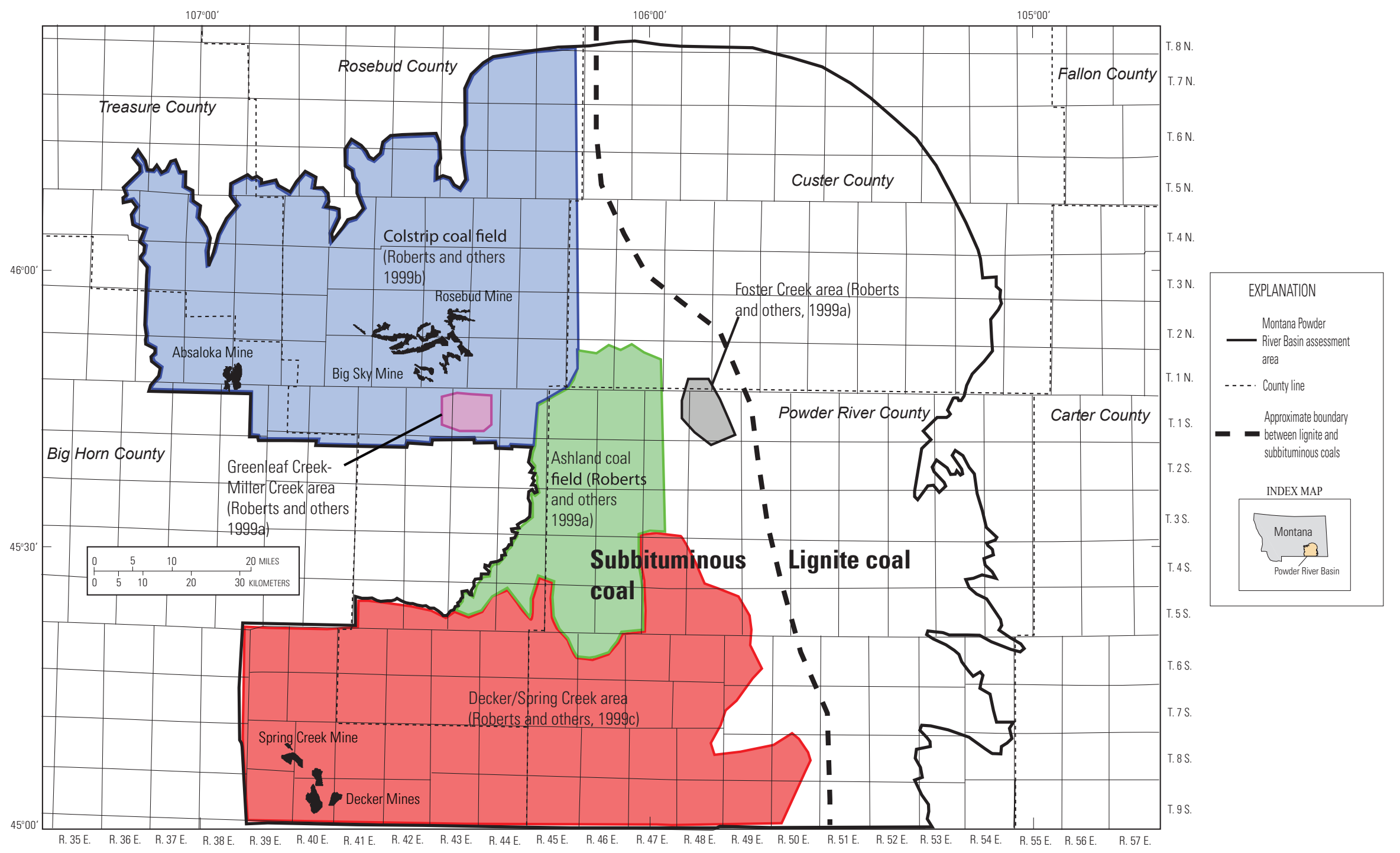

Figure 15. Map showing location of mines and area names for coal quality in the Montana Powder River Basin assessment area (see tables 5 and 6 for coal quality data). (Modified from Roberts and others, 1999a, 1999b, 1999c). 

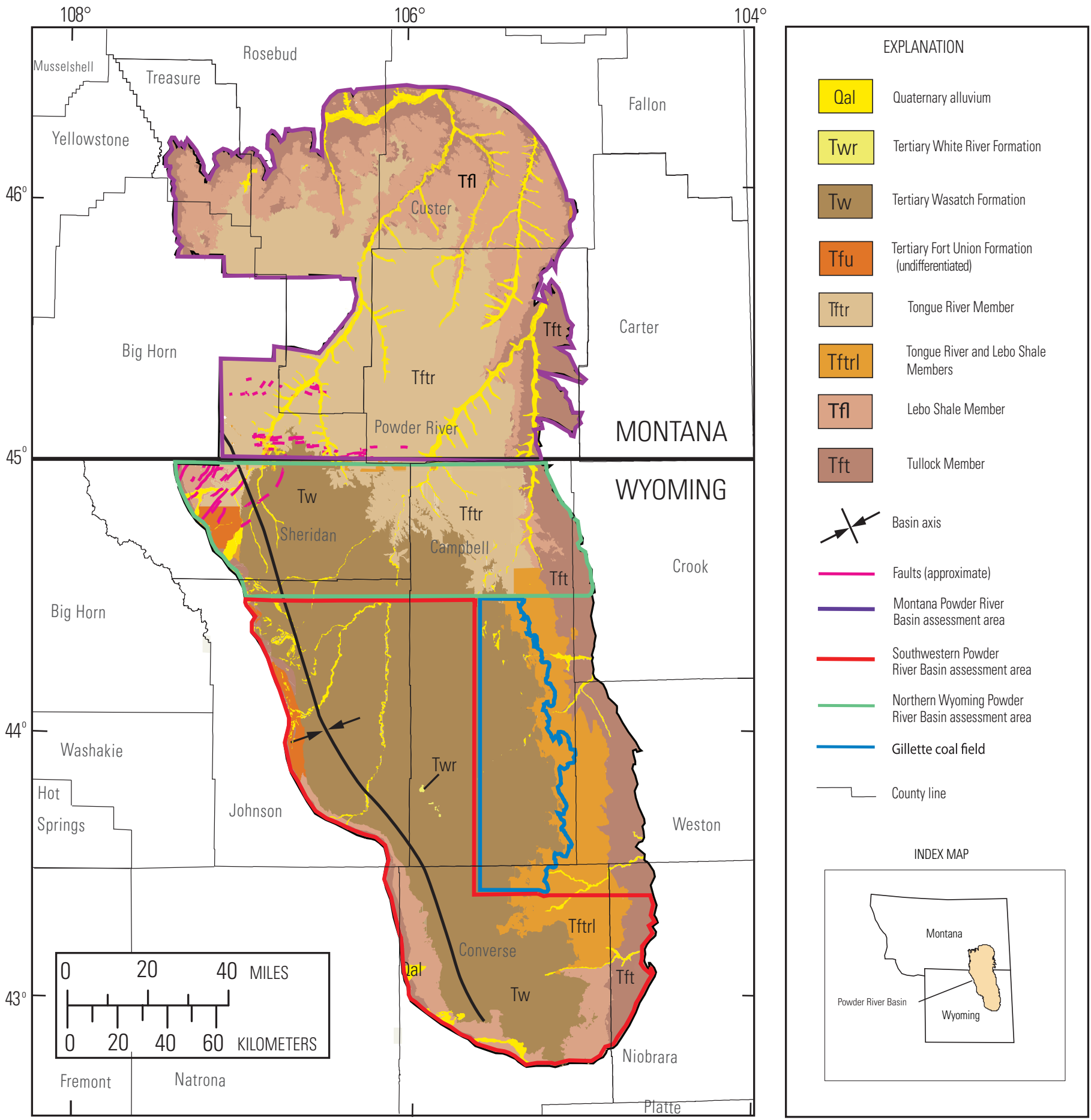

Figure 16. Map showing generalized geology of the Powder River Basin, Wyoming and Montana. (Modified from Flores and others, 1999, and Ellis and Colton, 1994). 

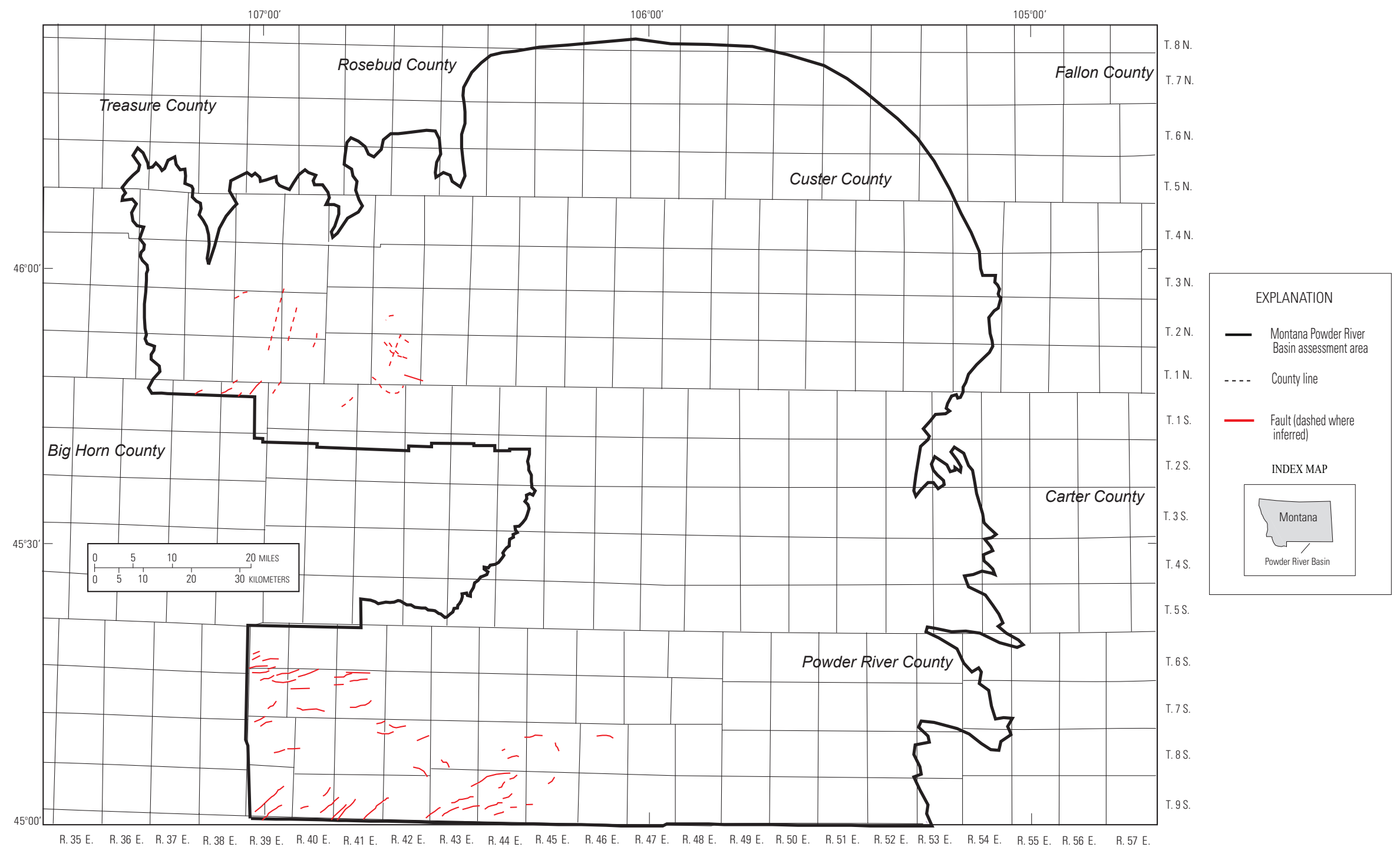

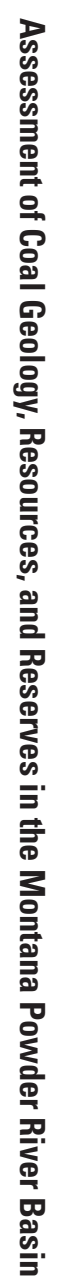

Figure 17. Map showing location of mapped faults in the Montana Powder River Basin assessment area. (Modified from Roberts and others, 


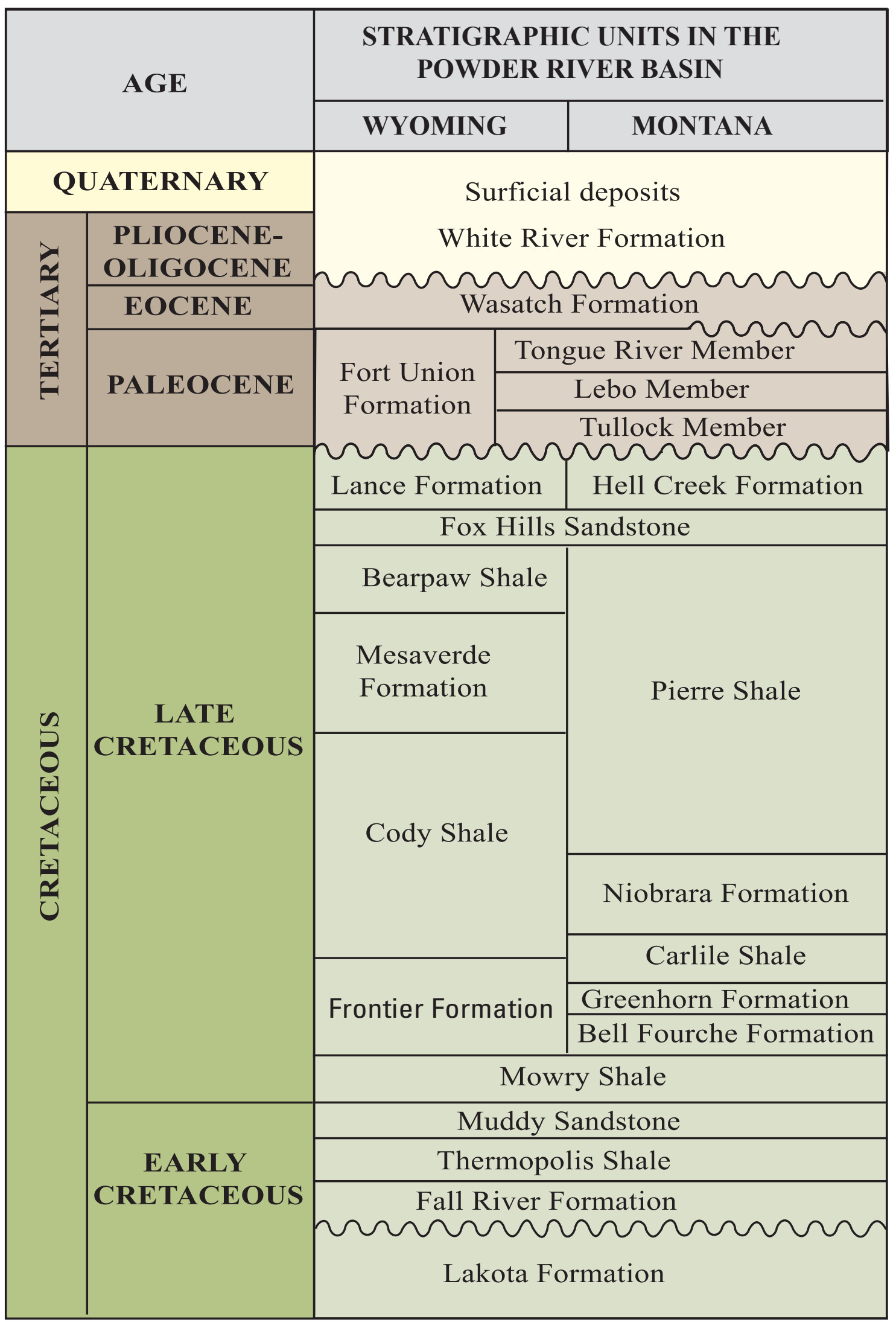

Figure 18. Generalized stratigraphic column for the Powder River Basin, Wyoming and Montana. (Modified from Ellis and others, 2002). 


\begin{tabular}{|c|c|c|c|c|c|c|c|c|}
\hline & \begin{tabular}{|c|} 
Kent and \\
others (1980)
\end{tabular} & \begin{tabular}{|c|} 
Pierce and \\
others $(1990)$
\end{tabular} & $\begin{array}{c}\text { Flores and } \\
\text { others, (1999) }\end{array}$ & $\begin{array}{c}\text { Ellis and } \\
\text { others (2002) }\end{array}$ & $\begin{array}{l}\text { Luppens and } \\
\text { others (2008) }\end{array}$ & $\begin{array}{c}\text { Scott and } \\
\text { others }(2010)\end{array}$ & $\begin{array}{c}\text { Osmonson and } \\
\text { others (2011) }\end{array}$ & $\begin{array}{l}\text { Assessed beds } \\
\text { for this report }\end{array}$ \\
\hline \multicolumn{9}{|c|}{ Bed Names } \\
\hline $\begin{array}{c}\text { WASATCH } \\
\text { FM }\end{array}$ & & Felix & & & $\begin{array}{l}\text { Upper Felix } \\
\text { Felix }\end{array}$ & $\begin{array}{l}\text { Upper Healy } \\
\text { Healy } \\
\text { Ucross } \\
\text { Felix } \\
\text { Lower Felix }\end{array}$ & \begin{tabular}{|c} 
Upper Healy, Healy \\
Murray \\
Ucross \\
Felix \\
Lower Felix \\
\end{tabular} & \\
\hline \multirow{16}{*}{$\begin{array}{c}\text { FORT UNION } \\
\text { FM } \\
\text { (Tongue } \\
\text { River } \\
\text { Member) }\end{array}$} & Smith & $\begin{array}{l}\text { Roland/ } \\
\text { Badger }\end{array}$ & Roland & $\begin{array}{l}\text { Wyodak } \\
\text { Rider }\end{array}$ & Roland & $\begin{array}{l}\text { Roland (Upper Rider) } \\
\text { Roland (Baker) } \\
\text { Roland (Taff) }\end{array}$ & $\begin{array}{c}\text { Roland (Upper Rider) } \\
\text { Roland (Lower Rider) } \\
\text { Roland (Baker) }\end{array}$ & Roland (Baker) \\
\hline & \multirow[b]{2}{*}{$\begin{array}{c}\text { Upper } \\
\text { Wyodak }\end{array}$} & \multirow{5}{*}{$\begin{array}{l}\text { Wyodak or } \\
\text { Upper Wyodak } \\
\text { (Anderson/ } \\
\text { Canyon) }\end{array}$} & \multirow{6}{*}{$\begin{array}{l}\text { Wyodak-Anderson } \\
\text { coal zone=Smith } \\
\text { (Swartz), Badger, } \\
\text { School, Sussex, Big } \\
\text { George, Wyodak, } \\
\text { Anderson, Dietz, } \\
\text { Canyon (Monarch), } \\
\text { Werner }\end{array}$} & \multirow[b]{2}{*}{$\begin{array}{c}\text { Upper } \\
\text { Wyodak }\end{array}$} & Smith & Smith & Smith & Smith \\
\hline & & & & & \begin{tabular}{|c}
$\begin{array}{c}\text { Anderson Rider, } \\
\text { Anderson }\end{array}$ \\
Dietz \\
\end{tabular} & $\begin{array}{l}\text { Anderson } \\
\text { Lower Anderson } \\
\text { Dietz 1, Dietz 2, } \\
\text { Dietz 3, Dietz } 4\end{array}$ & $\begin{array}{c}\text { Anderson } \\
\text { Dietz } 3 \\
\text { Upper Canyon }\end{array}$ & $\begin{array}{l}\text { Anderson } \\
\text { Dietz } 2 \\
\text { Dietz } 3\end{array}$ \\
\hline & \multirow[t]{3}{*}{ Canyon } & & & Canyon & Canyon & Canyon & Canyon & Canyon \\
\hline & & & & \multirow{3}{*}{$\begin{array}{c}\text { Lower } \\
\text { Wyodak }\end{array}$} & \multirow[b]{3}{*}{ Werner } & Lower Canyon & Lower Canyon & Lower Canyon \\
\hline & & & & & & Ferry & & Ferry \\
\hline & Werner & $\begin{array}{c}\text { Lower } \\
\text { Wyodak }\end{array}$ & & & & Werner & Werner & Werner/Cook \\
\hline & & & & & & Otter & Otter & Otter \\
\hline & $\begin{array}{c}\text { Gates/ } \\
\text { Kennedy }\end{array}$ & $\begin{array}{c}\text { Upper } \\
\text { Kennedy }\end{array}$ & & $\begin{array}{c}\text { Gates/ } \\
\text { Kennedy }\end{array}$ & Gates & Gates & Gates & Gates/Wall \\
\hline & & & & & Pawnee & Pawnee & Pawnee & Pawnee \\
\hline & & & & & & Odell & & Odell \\
\hline & & & Rosebud & & & & Deep 1 & Rosebud/Knobloch \\
\hline & & & McKay & & & & Deep 2 & McKay/Nance \\
\hline & & & & & & & Deep 3 & Flowers-Goodale \\
\hline & & & Robinson & & & & & Robinson/Witham \\
\hline & & & & & & Roberts & Roberts & Roberts/Terret \\
\hline
\end{tabular}




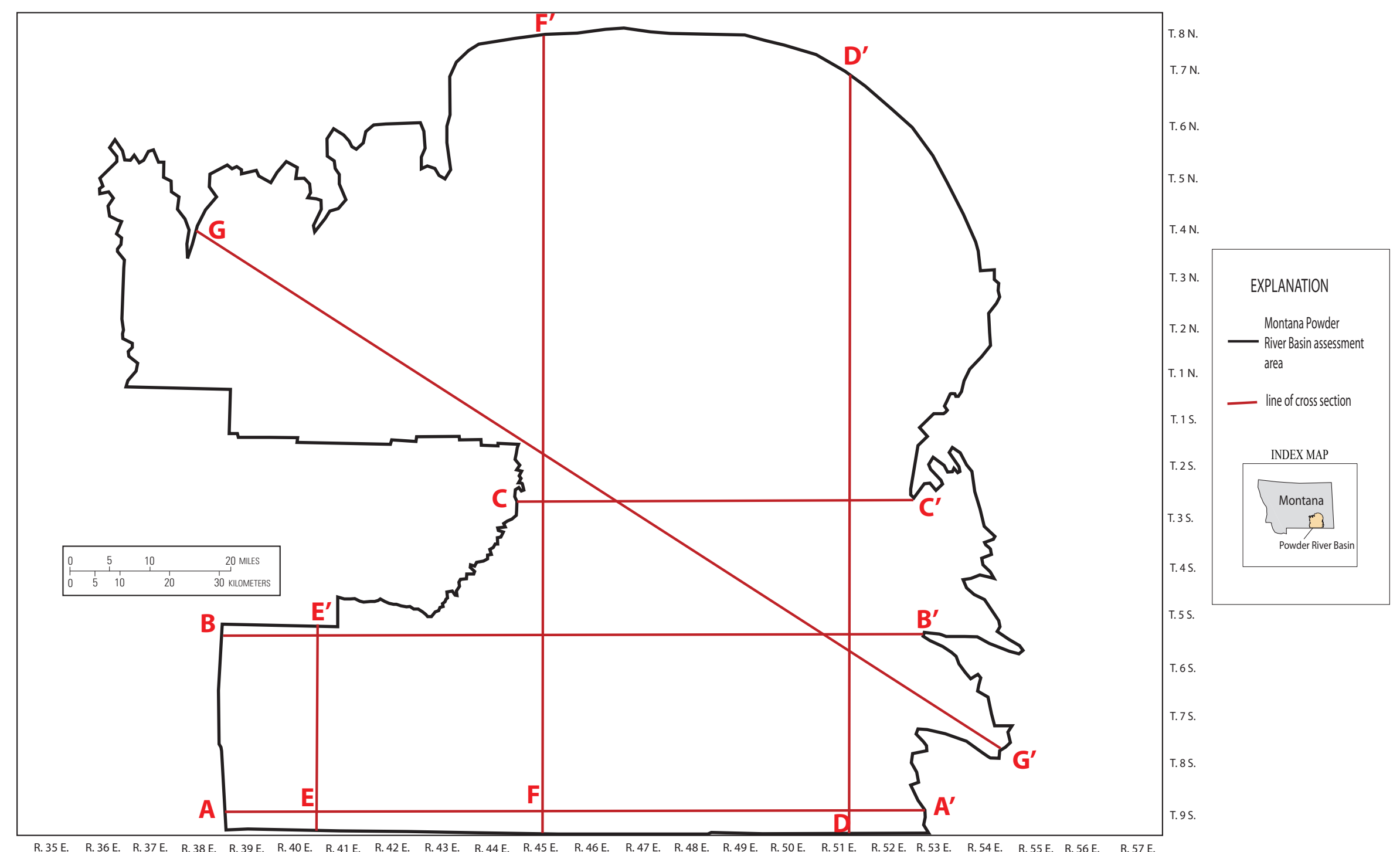

Figure 20. Index map showing locations of cross sections in figures 21-27 in the Montana Powder River Basin assessment area. 


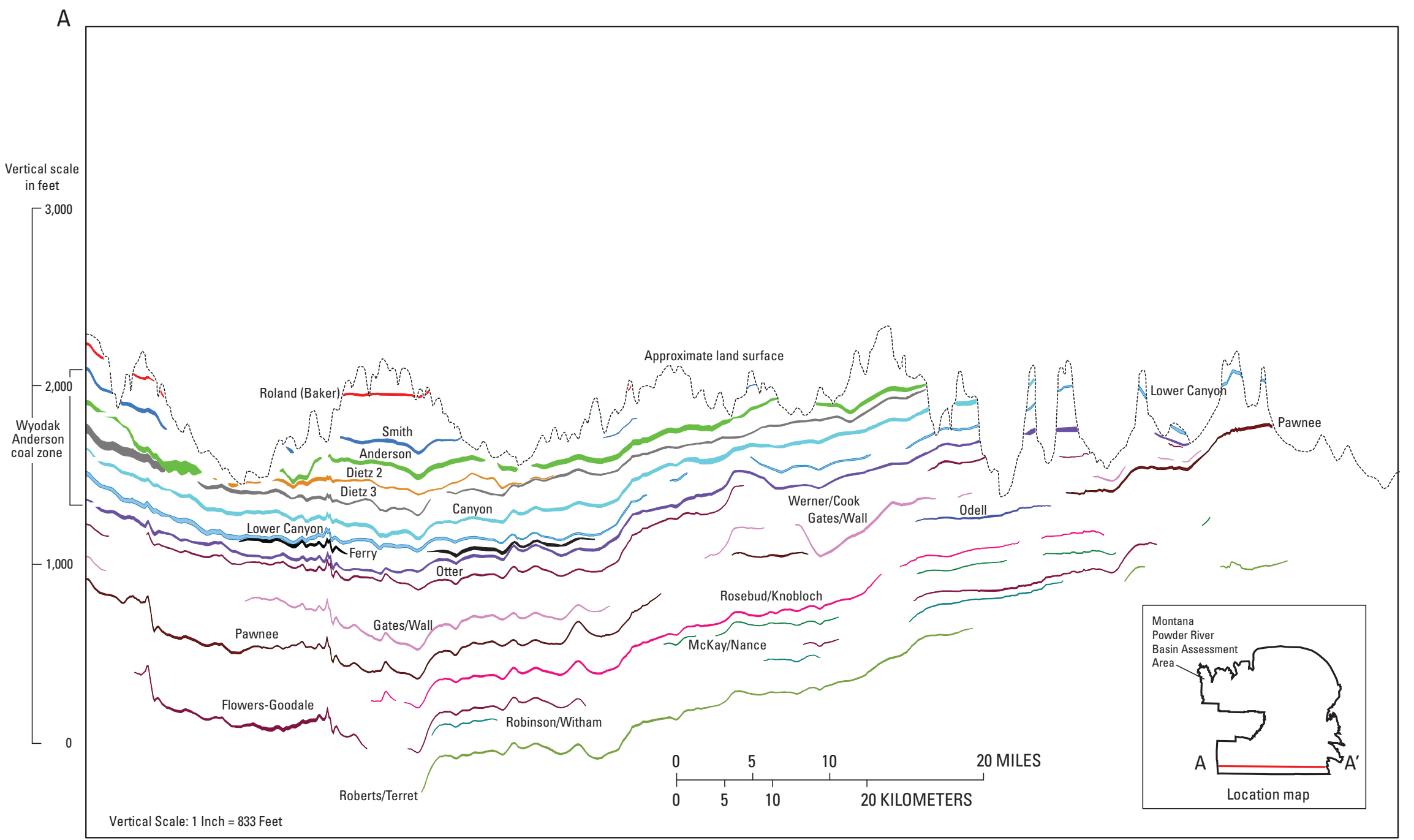

Figure 21. West-east cross section A-Á showing subsurface distribution of coal beds through the Spring Creek and Decker Mine areas in the Montana Powder River Basin assessment area. (Vertical exaggeration approximately $63 \mathrm{X}$ ). 


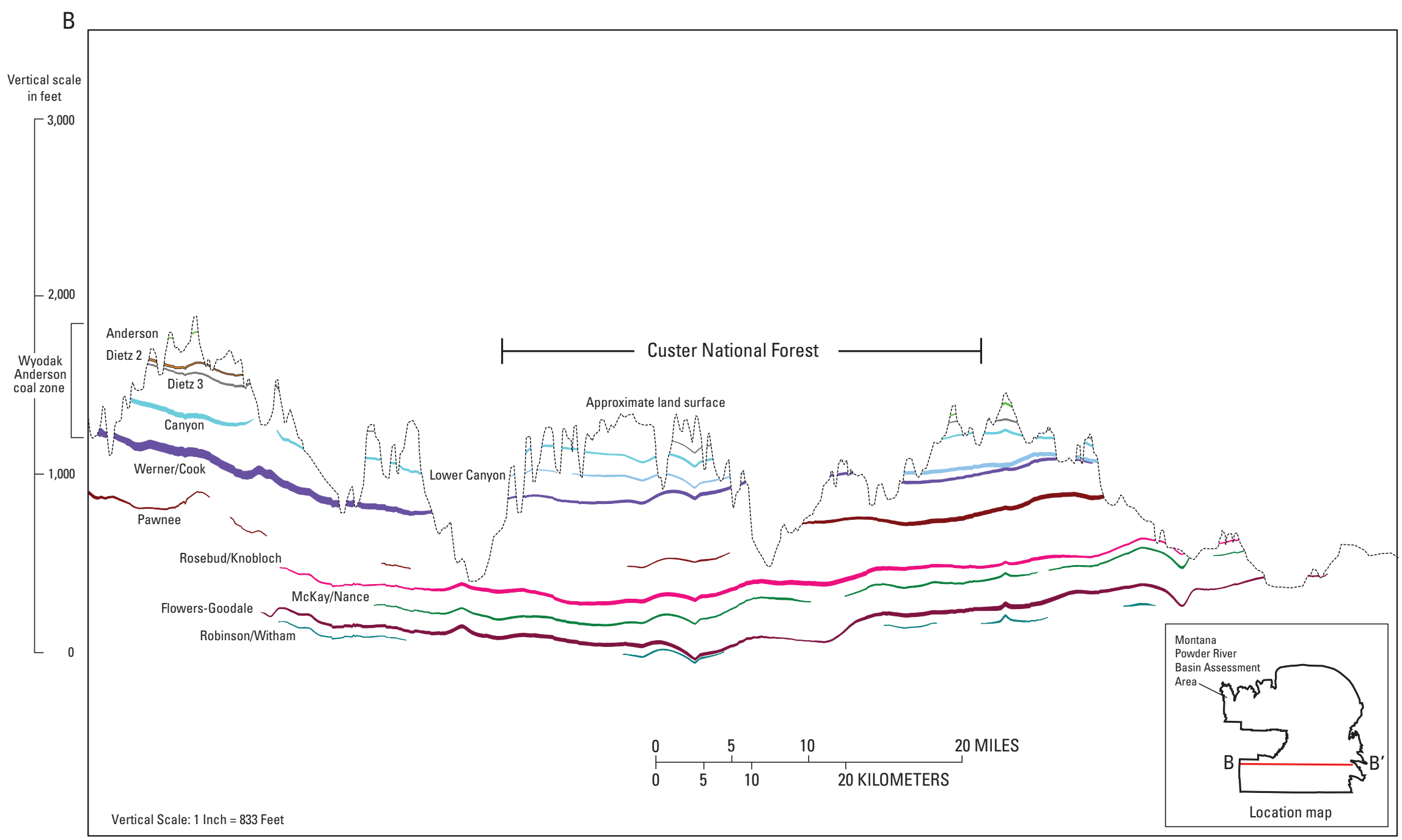

Figure 22. West-east cross section B-B' showing subsurface distribution of coal beds north of the Spring Creek and Decker Mine areas in the Montana Powder River Basin assessment area. (Vertical exaggeration approximately 63 X). 


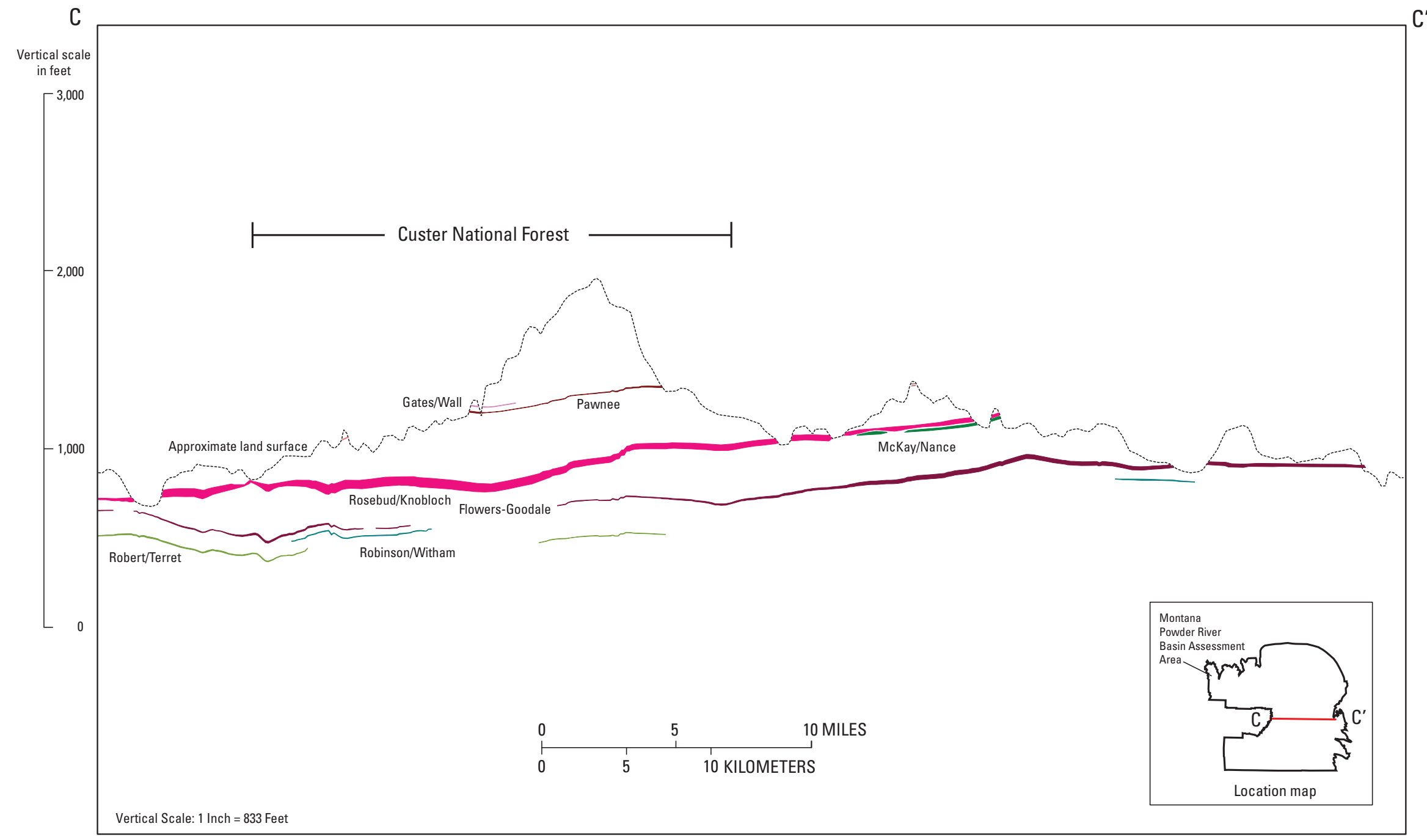

Figure 23. West-east cross section C-C' showing subsurface distribution of coal beds through the Otter Creek Tracts (Arch Coal, Inc.) in the Montana Powder River Basin assessment area. (Vertical exaggeration approximately $32 \mathrm{X}$ ). 


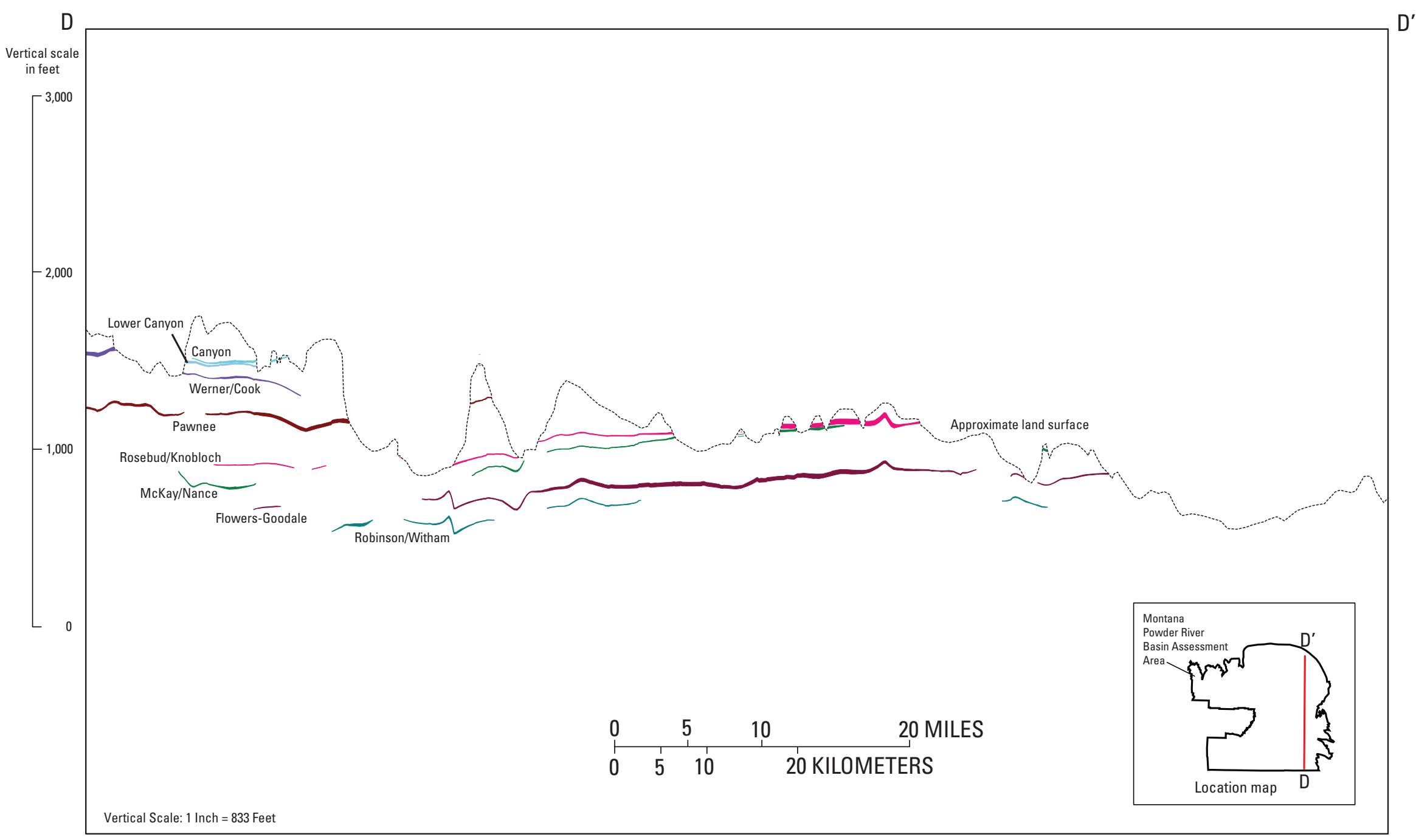

Figure 24. South-north cross section D-D' showing subsurface distribution of coal beds through the eastern part of the Montana Powder River Basin assessment area. (Vertical exaggeration approximately $63 \mathrm{X}$ ) 


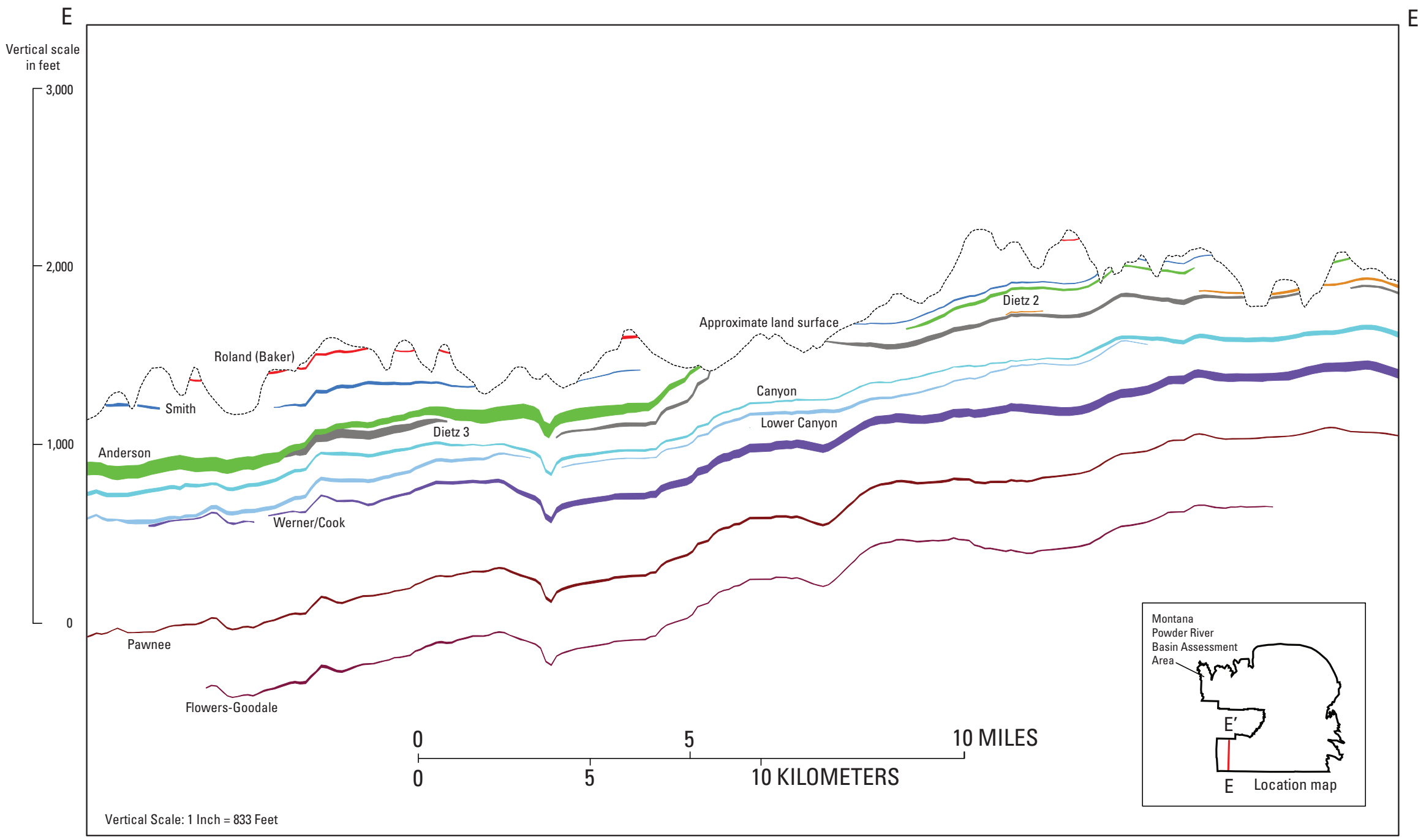

Figure 25. South-north cross section E-E' showing subsurface distribution of coal beds through the Spring Creek and Decker Mine areas, Montana Powder River Basin assessment area. (Vertical exaggeration approximately $16 \mathrm{X}$ ). 


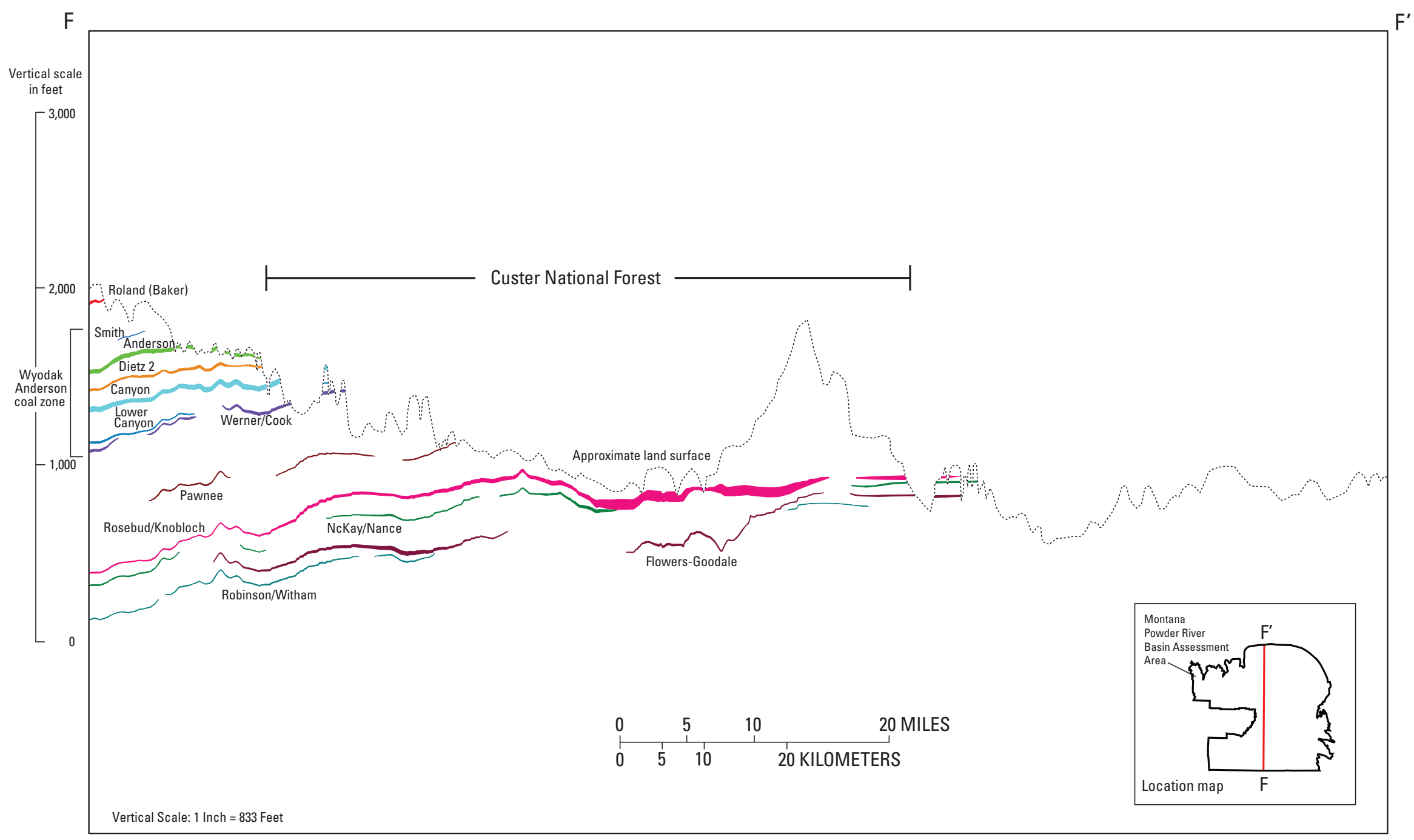

Figure 26. South-north cross section F-F' showing subsurface distribution of coal beds through the central part of the Montana Powder River Basin assessment area. (Vertical exaggeration approximately $70 \mathrm{X}$ ). 


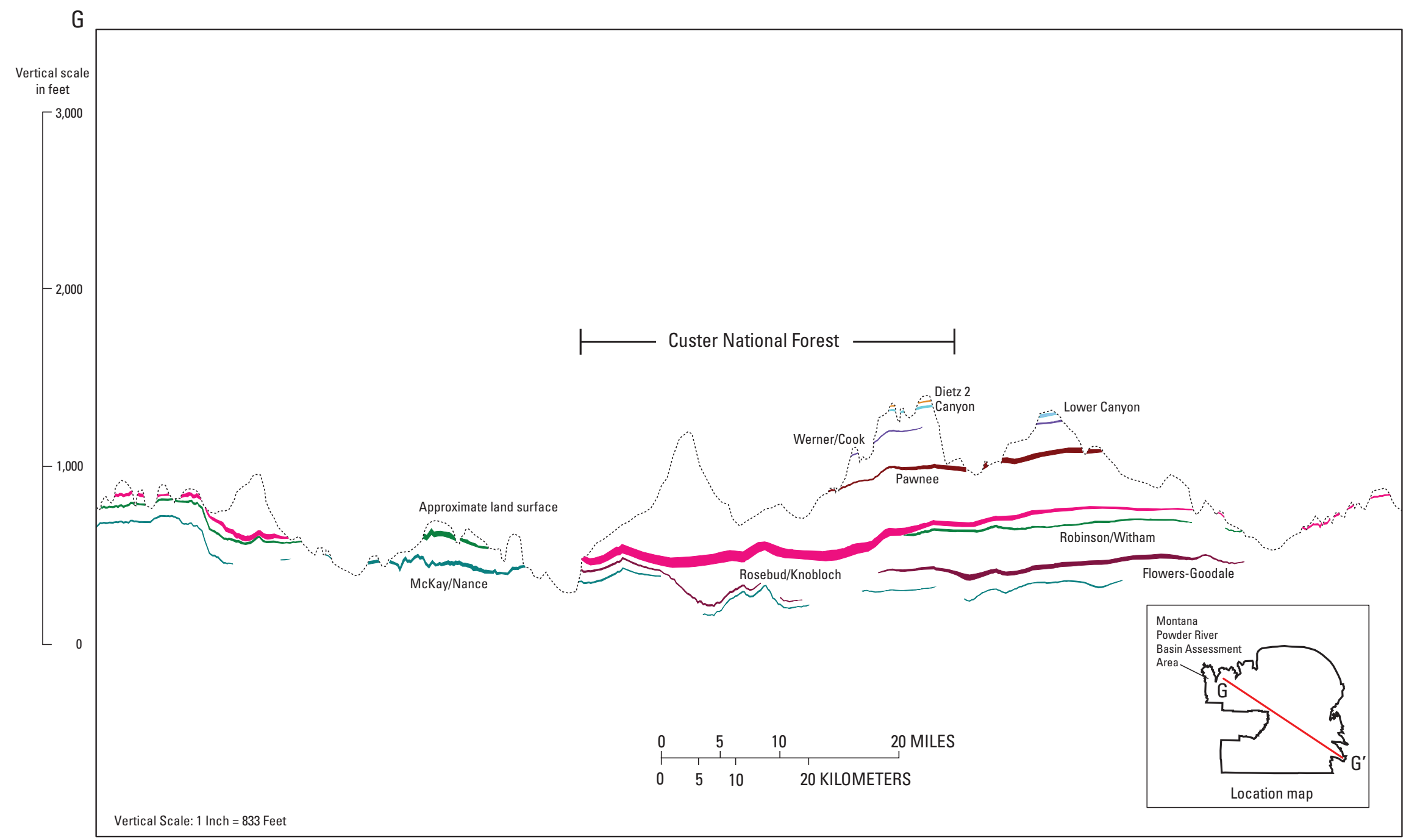

Figure 27. Northwest-southeast cross section G-G' showing subsurface distribution of coal beds through the Montana Powder River Basin assessment area. (Vertical exaggeration approximately $76 \mathrm{X})$. 


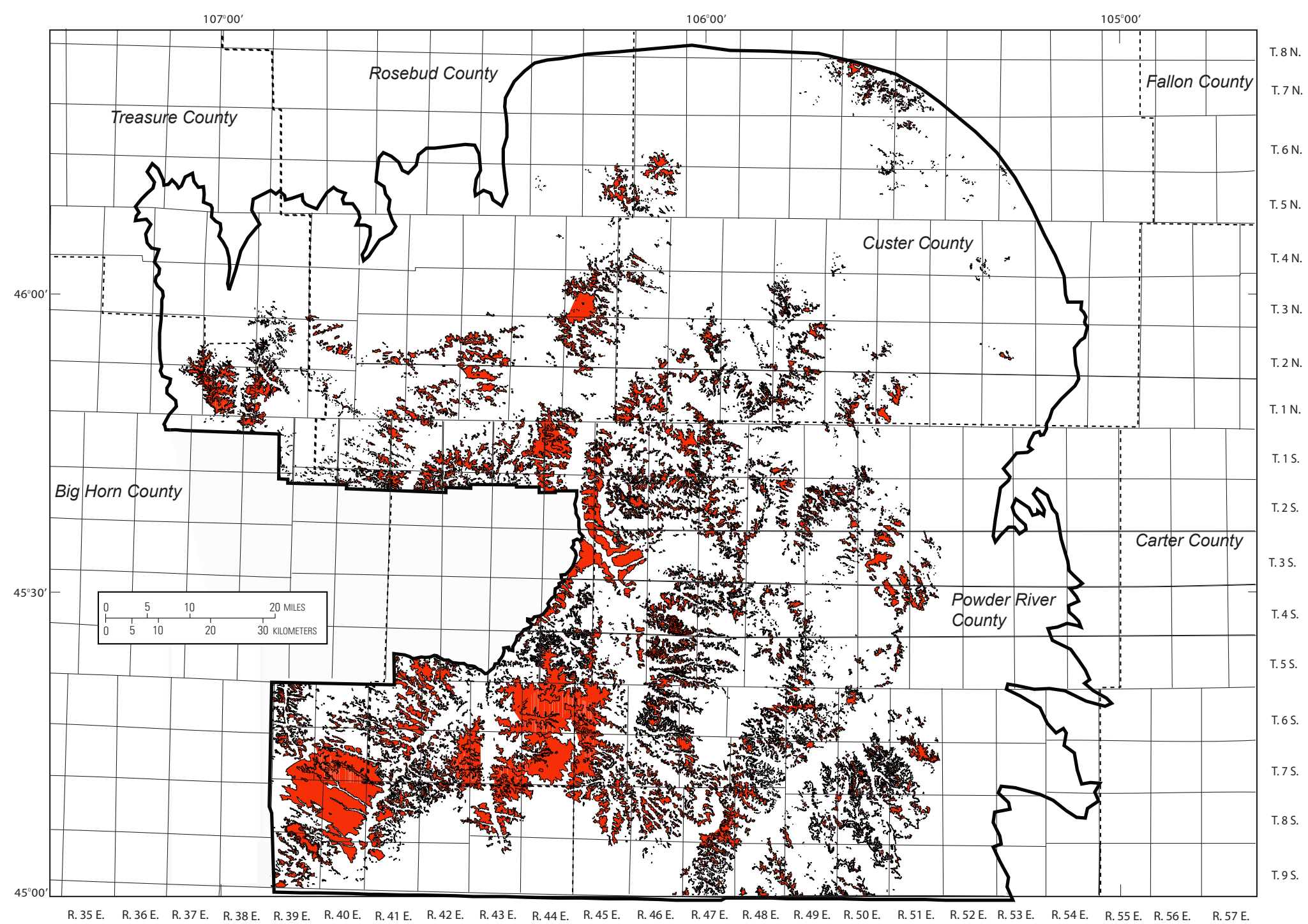

EXPLANATION

- Montana Powder River

Basin assessment area

-... County line

Clinker

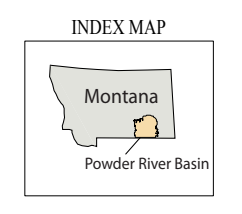

Figure 28. Map showing location of clinker in the Montana Powder River Basin assessment area. (Modified from Heffern and others, 1993). 


\section{Coal Stratigraphy}

\begin{tabular}{|c|c|c|c|c|c|}
\hline & $\begin{array}{c}\text { Coal Beds } \\
\text { identified in this } \\
\text { assessment (26) }\end{array}$ & $\begin{array}{c}\text { Coal Bed Names/ } \\
\text { Resources } \\
\text { calculated }(18) \\
\text { (see tables } 4,8,9)\end{array}$ & \begin{tabular}{|c} 
Coal Bed Namesl \\
Reserves \\
calculated
\end{tabular} & $\begin{array}{c}\text { Maximum } \\
\text { thickness } \\
\text { (feet) }\end{array}$ & \begin{tabular}{|c} 
Average \\
thickness \\
(feet)
\end{tabular} \\
\hline \multirow{14}{*}{$\begin{array}{l}\text { FORT UNION } \\
\text { Formation } \\
\text { (Tongue RiveI }\end{array}$} & Roland (Baker) & Roland (Baker) & Roland (Baker) & 14 & 6 \\
\hline & Roland (Taff) & & & & \\
\hline & Smith & Smith & Smith & 20 & 6 \\
\hline & Anderson & Anderson & Anderson & 93 & 22 \\
\hline & Dietz 1 & & & & \\
\hline & Dietz 2 & Dietz 2 & Dietz 2 & 32 & 6 \\
\hline & Dietz 3 & Dietz 3 & Dietz 3 & 59 & 11 \\
\hline & Dietz 4 & & & & \\
\hline & Cox & & & & \\
\hline & Canyon & Canyon & Canyon & 57 & 14 \\
\hline & Lower Canyon & Lower Canyon & & 42 & 8 \\
\hline & Ferry & Ferry & & 15 & 6 \\
\hline & Werner/Cook & Werner/Cook & Werner/Cook & 62 & 15 \\
\hline & Otter & Otter & & 32 & 4 \\
\hline \multirow[t]{12}{*}{ Member) } & Gates/Wall & Gates/Wall & & 23 & 5 \\
\hline & Pawnee & Pawnee & Pawnee & 34 & 8 \\
\hline & Brewster-Arnold & & & & \\
\hline & Odell & Odell & & 14 & 3 \\
\hline & Cache & & & & \\
\hline & Rosebud/Knobloch & Rosebud/Knobloch & Rosebud/Knobloch & 72 & 15 \\
\hline & Calvert & & & & \\
\hline & McKay/Nance & McKay/Nance & & 30 & 9 \\
\hline & Flowers-Goodale & Flowers-Goodale & Flowers-Goodale & 35 & 9 \\
\hline & Upper Witham & & & & \\
\hline & Robinson/Witham & Robinson/Witham & & 37 & 6 \\
\hline & Roberts/Terret & Roberts/Terret & & 28 & 5 \\
\hline
\end{tabular}

Figure 29. Coal stratigraphy in the Montana Powder River Basin assessment area, showing names used in this report. Maximum and average thickness shown for 18 coal beds assessed for resources and reserves in this report. 


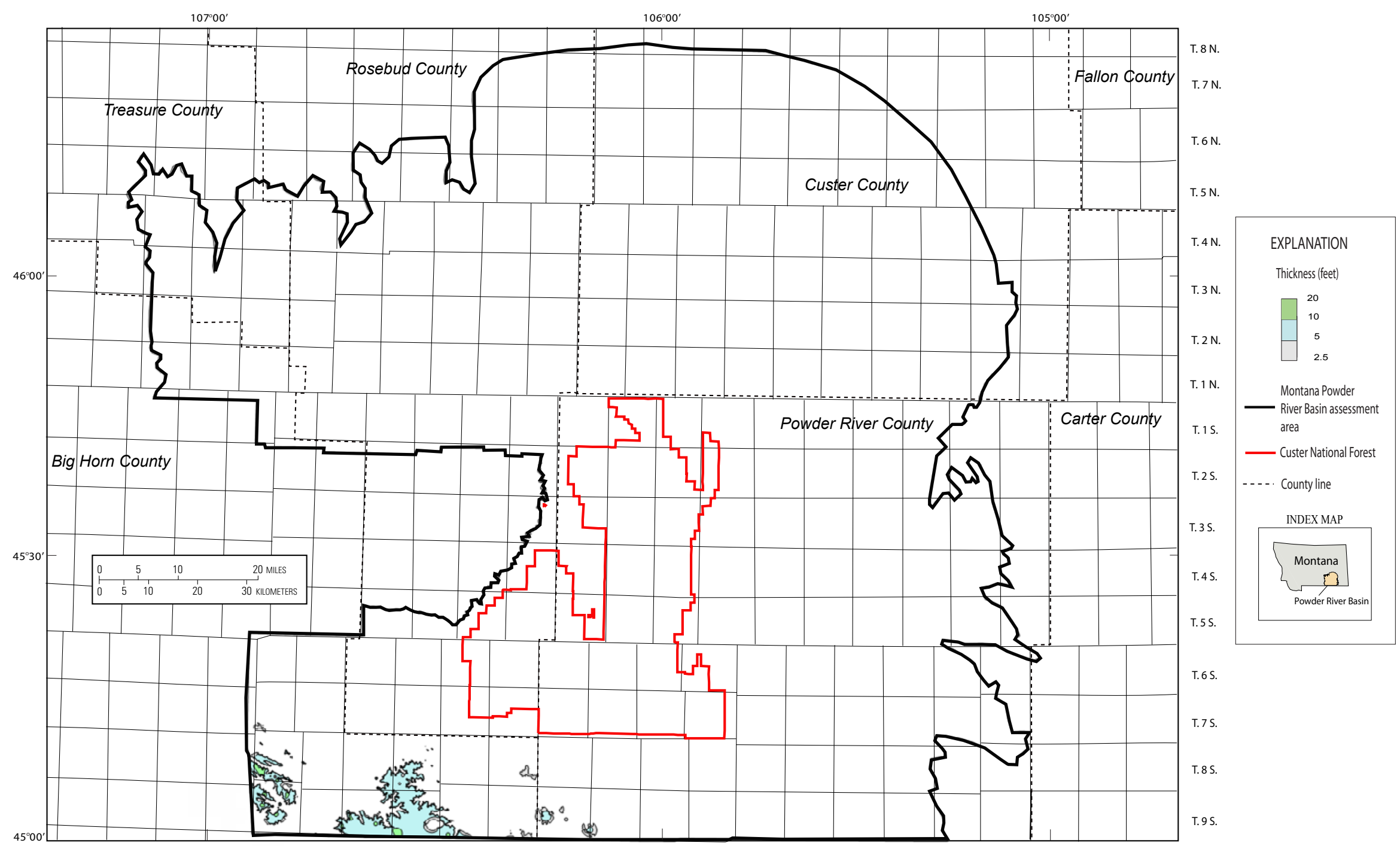

R. 35 E. R. 36 E. R. 37 E. R. 38 E. R. 39 E. R. 40 E. R. 41 E. R. 42 E. R. 43 E. R. R. 44 E. R. 45 E. R. 46 E. R. R. 47 E. R. 48 E. R. R. 49 E. R. 50 E. R. R. 51 E. R. 52 E. R. 53 E. R. 54 E. R. 55 E. R. 56 E. R. 57 E.

Figure 30. Isopachs showing extent of resources at least 2.5 feet thick in the Roland (Baker) coal bed within the Montana Powder River Basin assessment area. 


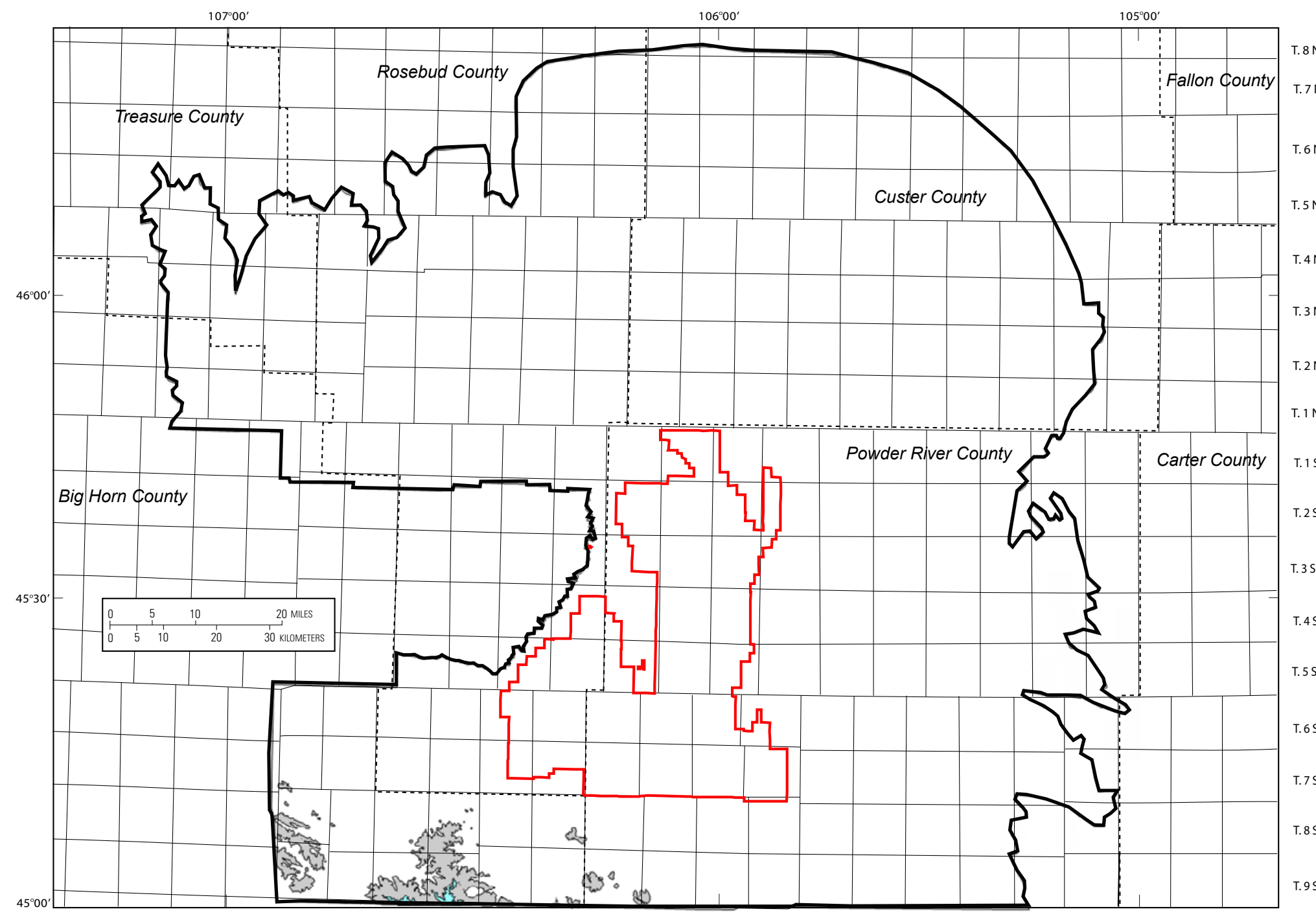

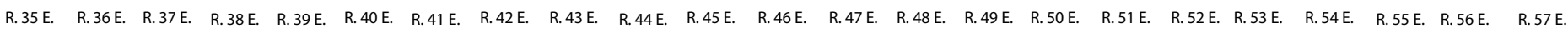

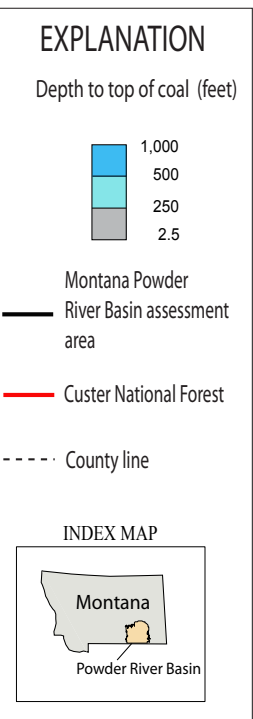

Figure 31. Map showing depth to the top of the Roland (Baker) coal bed within the Montana Powder River Basin assessment area. 


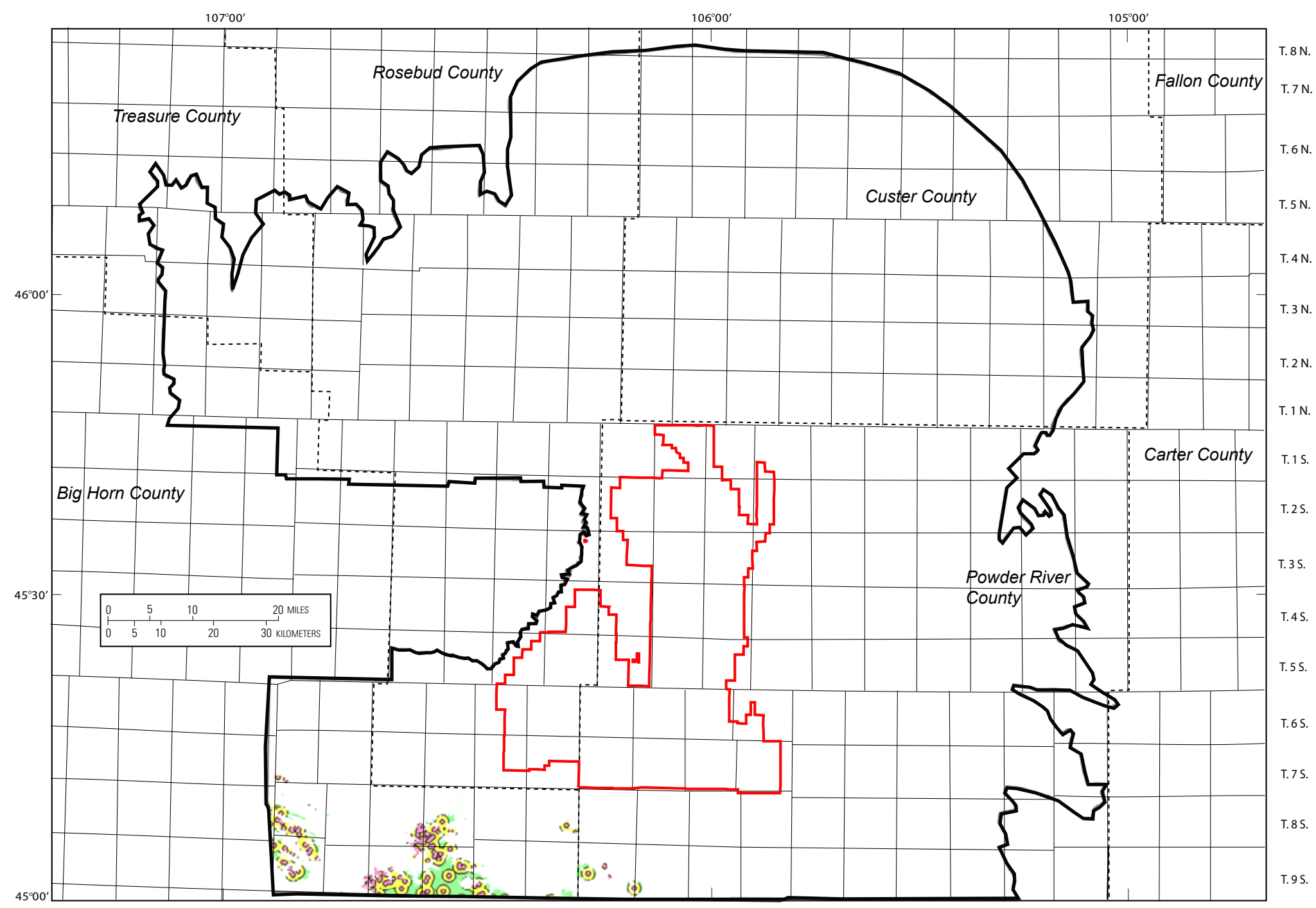

— Custer National Forest

.... County line

INDEX MAP

Powder River Basin

Figure 32. Map showing coal resource reliability categories for the Roland (Baker) coal bed within the Montana Powder River Basin assessment area. 


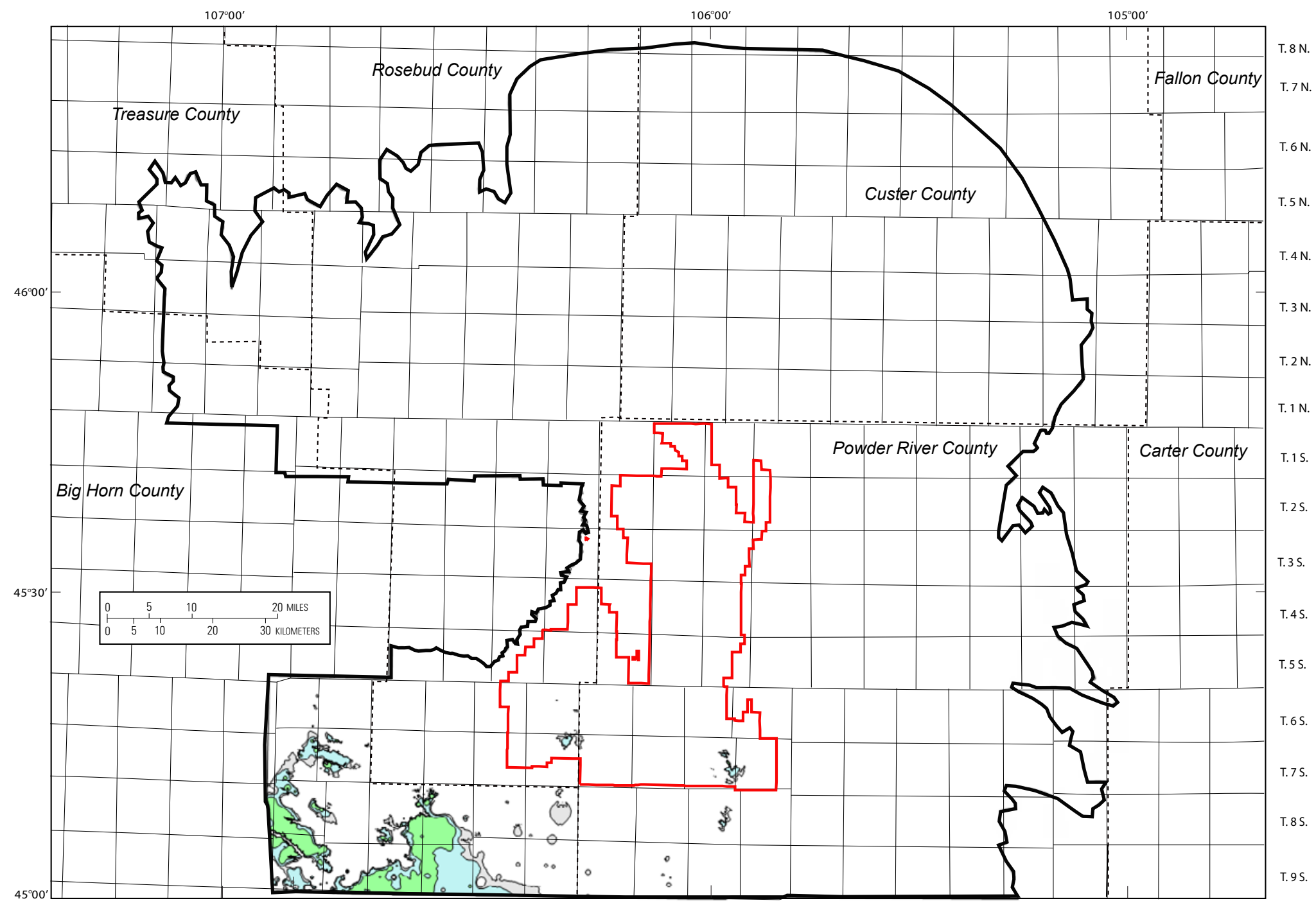

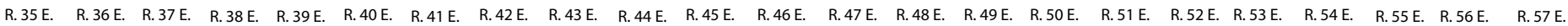

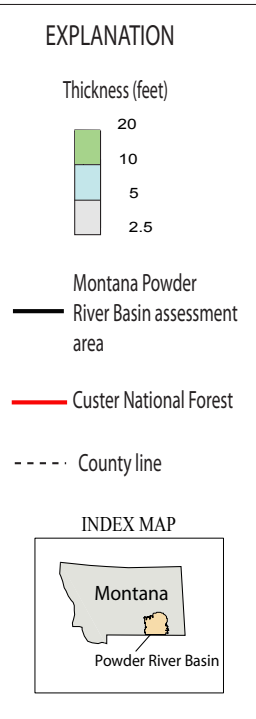

Figure 33. Isopachs showing extent of resources at least 2.5 feet thick in the Smith coal bed within the Montana Powder River Basin assessment area. 

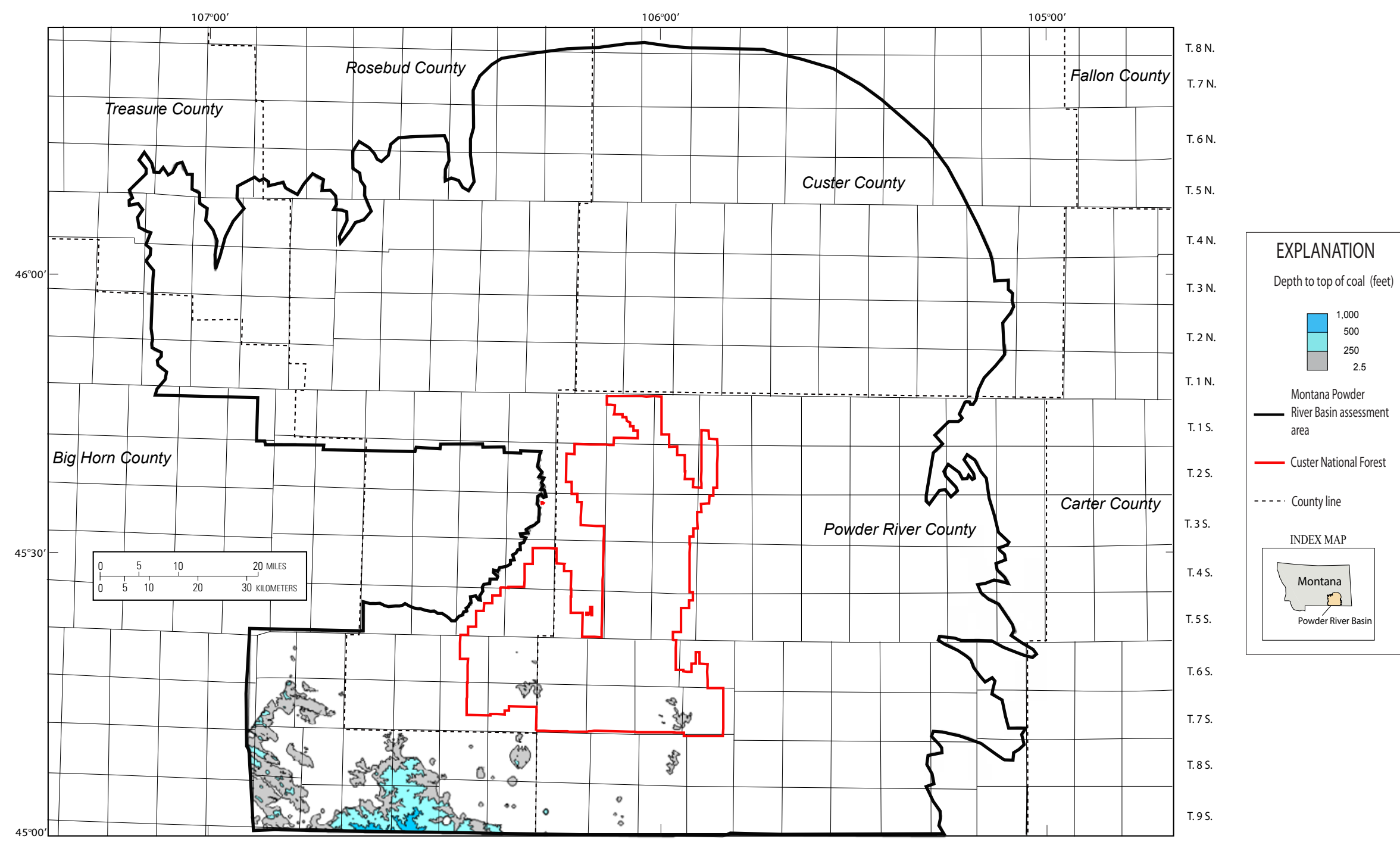

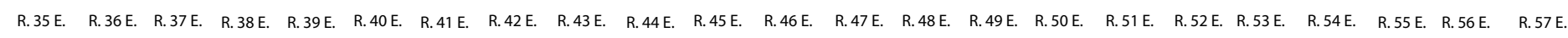

Figure 34. Map showing depth to the top of the Smith coal bed within the Montana Powder River Basin assessment area. 


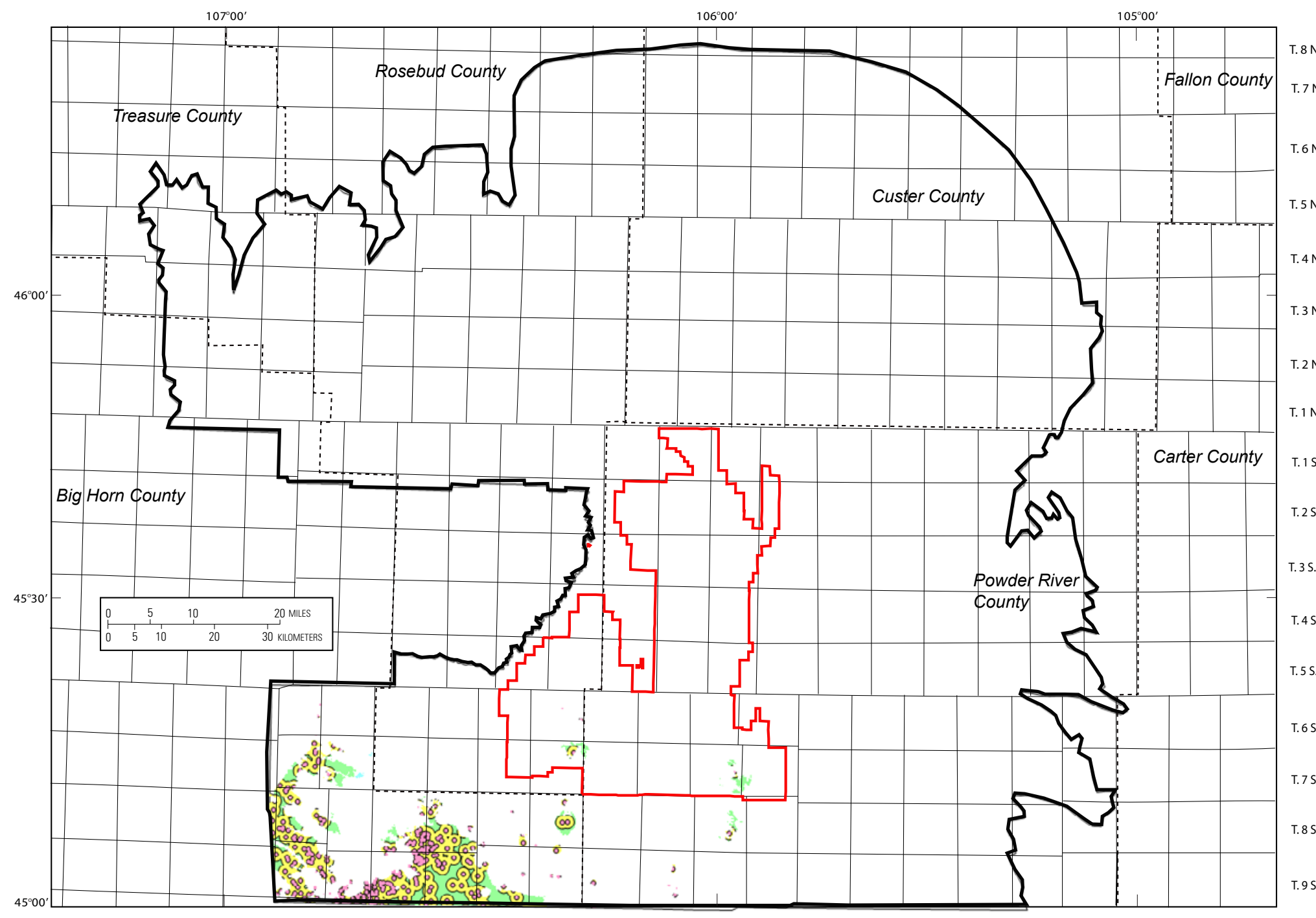

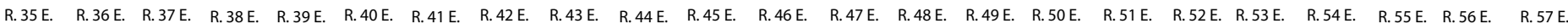

\begin{tabular}{|c|}
\hline EXPLANATION \\
\hline Hypothetical \\
\hline Inferred \\
\hline Indicated \\
\hline Measured \\
\hline Montana Powder \\
\hline area \\
\hline - Custer National Forest \\
\hline County line \\
\hline INDEX MAP \\
\hline Montana \\
\hline Powder River Basin \\
\hline
\end{tabular}

Figure 35. Map showing coal resource reliability categories for the Smith coal bed within the Montana Powder River Basin assessment area. 


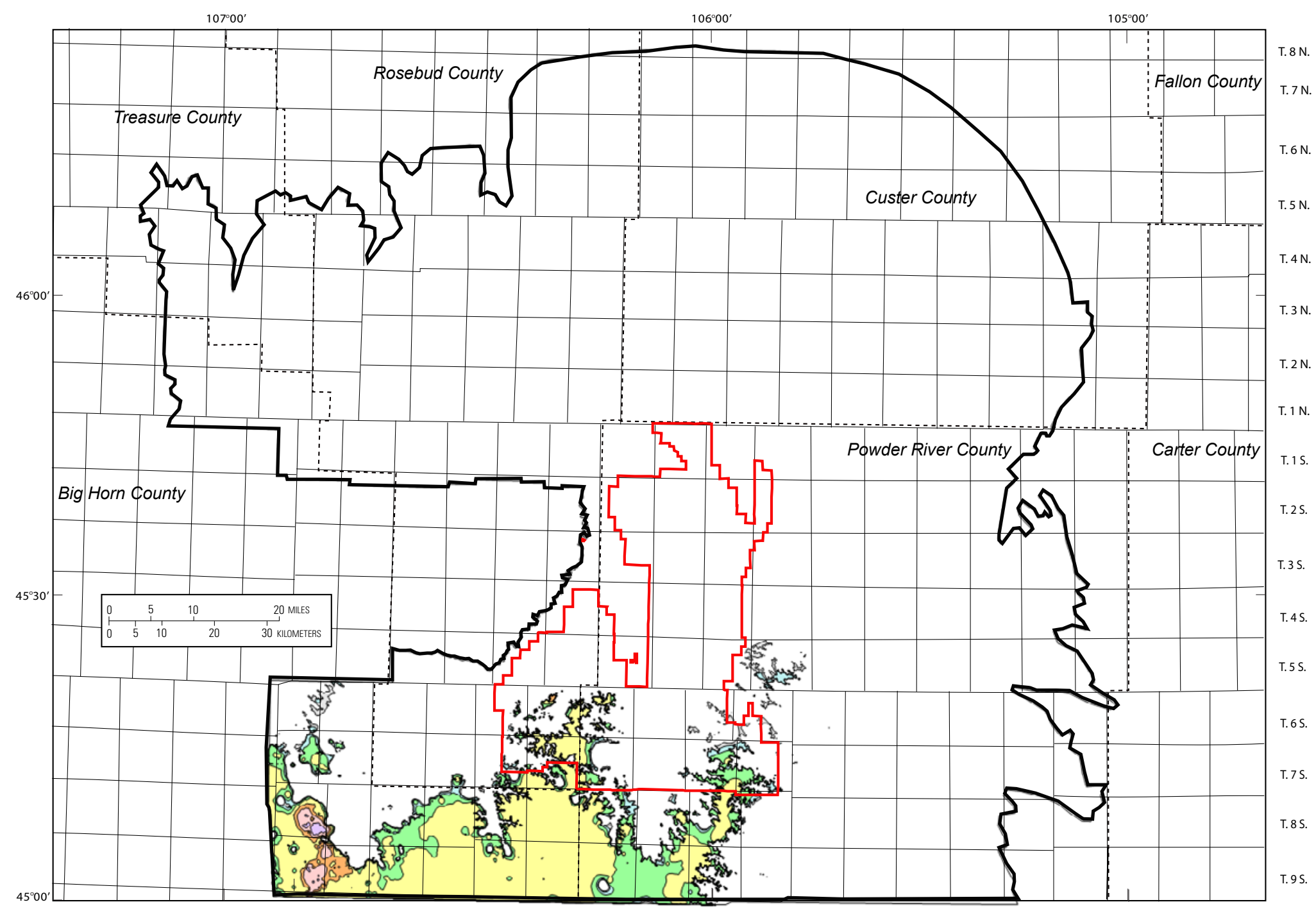

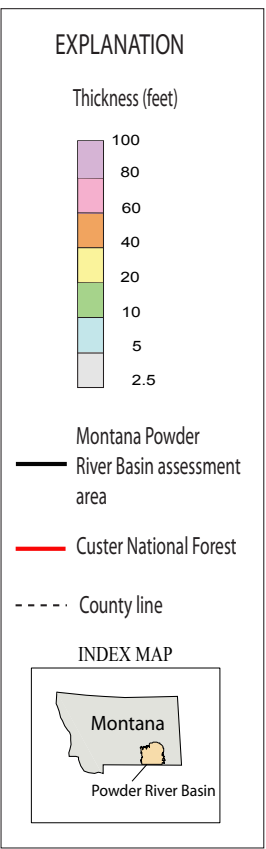

Figure 36. Isopachs showing extent of resources at least 2.5 feet thick in the Anderson coal bed within the Montana Powder River Basin assessment area. 


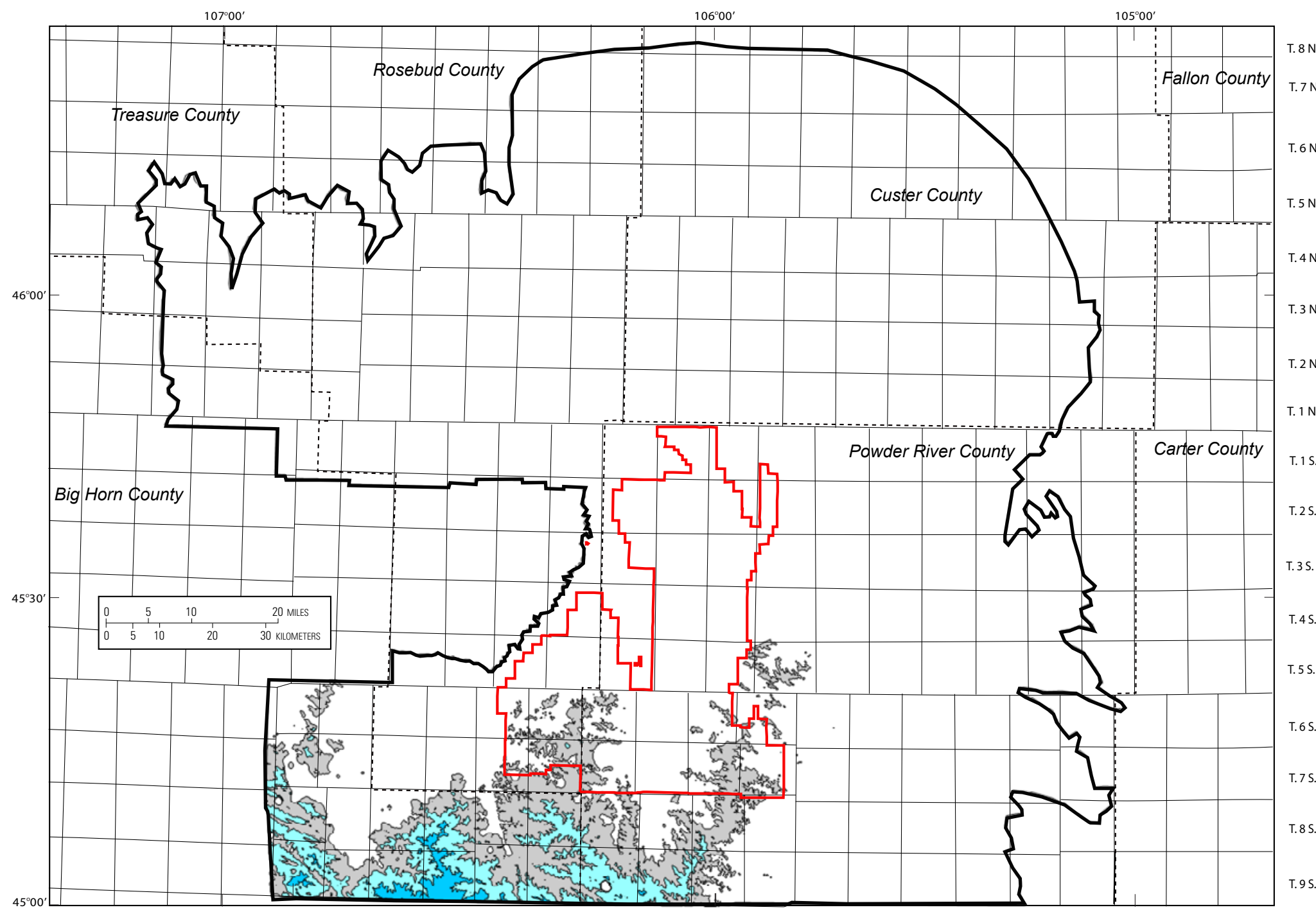

EXPLANATION

Depth to top of coal (feet)

__ Custer National Forest

-... County line

INDEX MAP

Montana

25

Powder River Basin

R. 35 E. R. 36 E. R. 37 E. R. 38 E. R. 39 E. R. 40 E. R. 41 E. R. 42 E. R. 43 E. R. 44 E. R. 45 E. R. R. 46 E. R. R. 47 E. R. 48 E. R. 49 E. R. 50 E. R. R. 51 E. R. 52 E. R. 53 E. R. 54 E. R. 55 E. R. 56 E. R. 57 E.

Figure 37. Map showing depth to the top of the Anderson coal bed within the Montana Powder River Basin assessment area. 


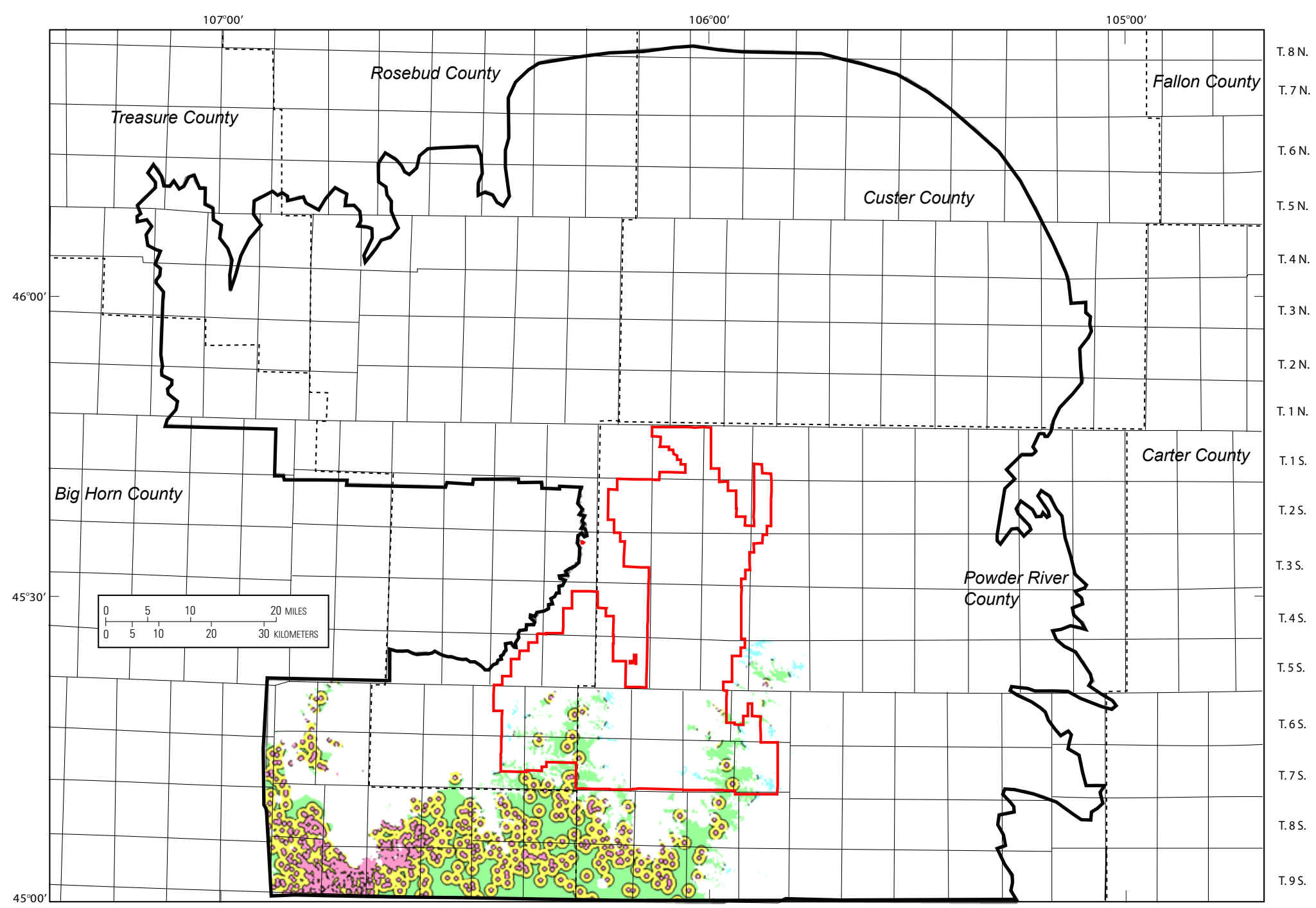

R. 35 E. R. 36 E. R. 37 E. R. 38 E. R. 39 E. R. 40 E. R. 41 E. R. 42 E. R. 43 E. R. R. 44 E. R. 45 E. R. 46 E. R. 47 E. R. R. 48 E. R. 49 E. R. 50 E. R. 51 E. R. 52 E. R. 53 E. R. 54 E. R. 55 E. R. 56 E. R. 57 E.

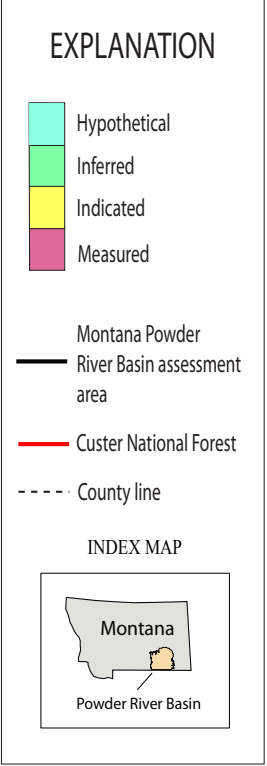

Figure 38. Map showing coal resource reliability categories for the Anderson coal bed within the Montana Powder River Basin assessment area. 

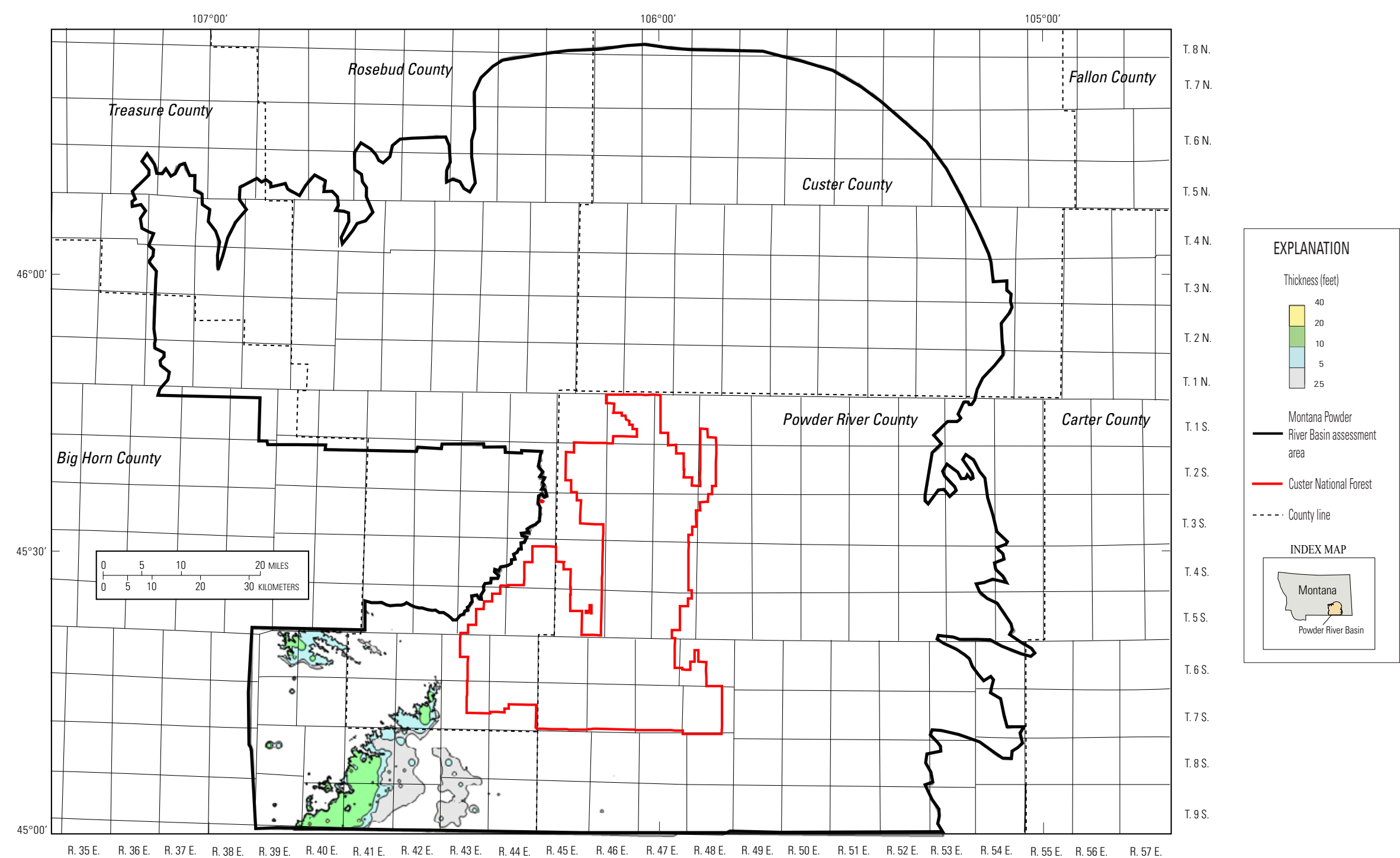

Figure 39. Isopachs showing extent of resources at least 2.5 feet thick in the Dietz 2 coal bed within the Montana Powder River Basin assessment area. 

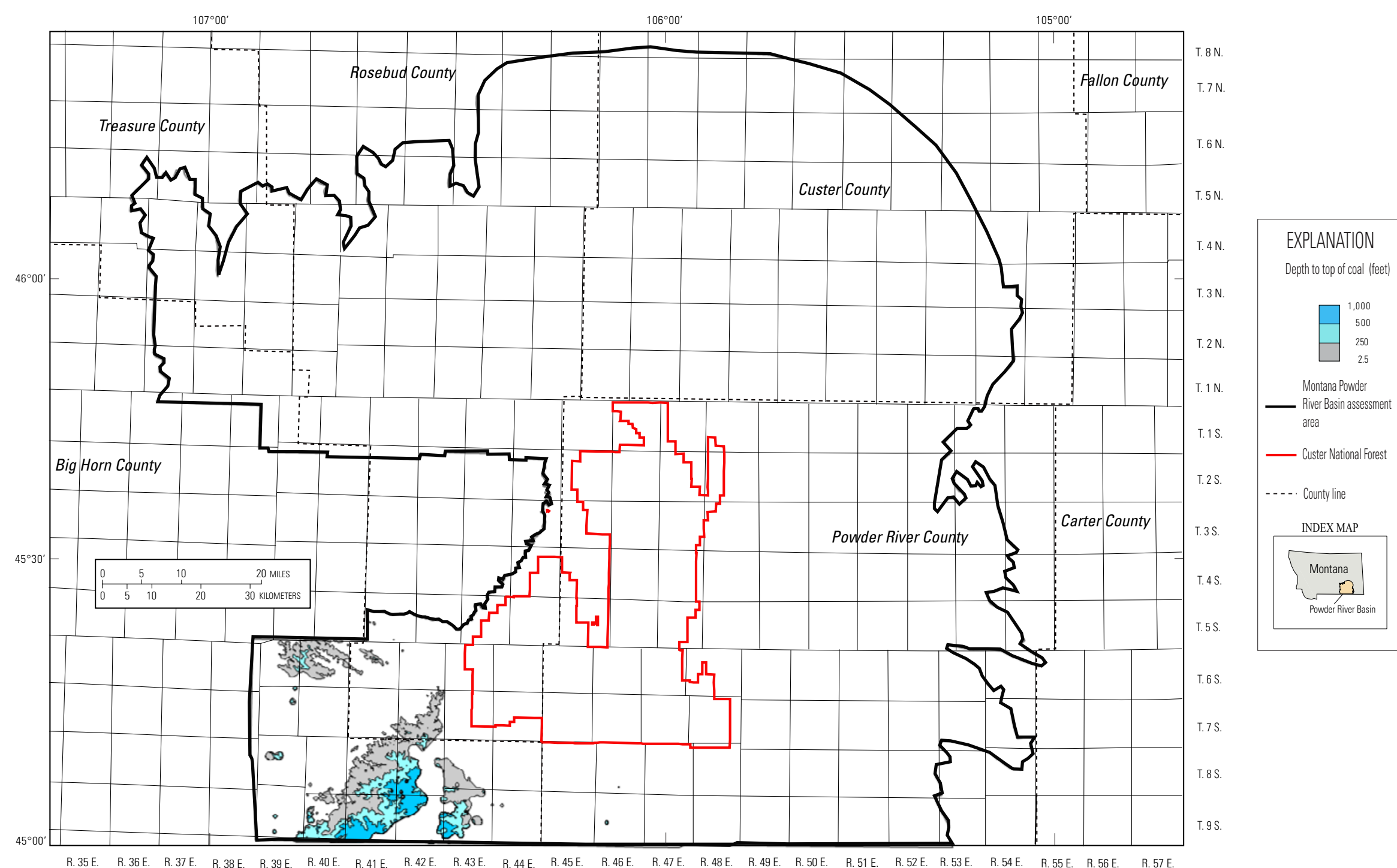

Figure 40. Map showing depth to the top of the Dietz 2 coal bed within the Montana Powder River Basin assessment area. 


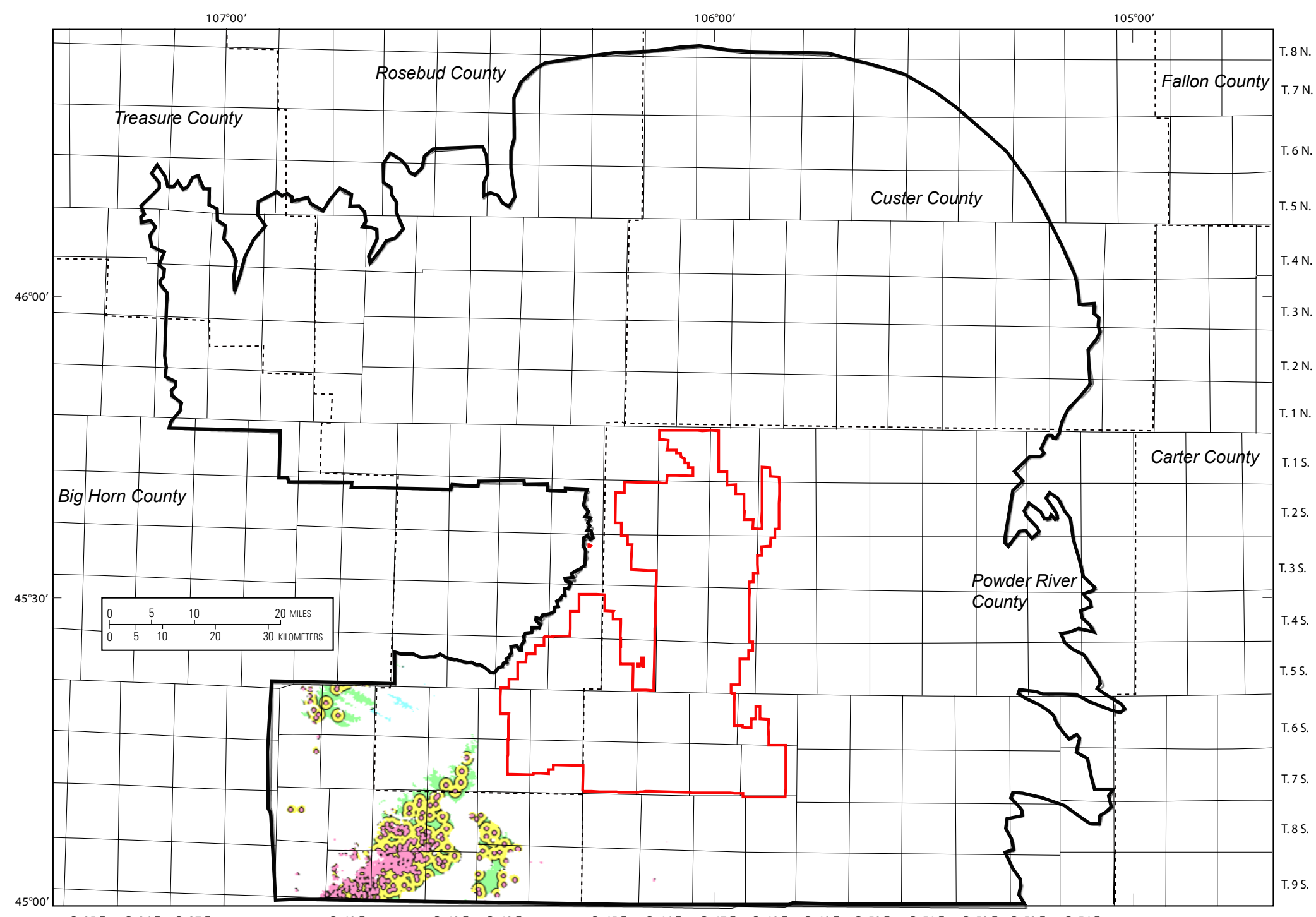

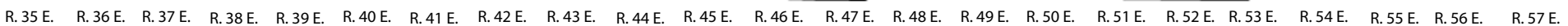

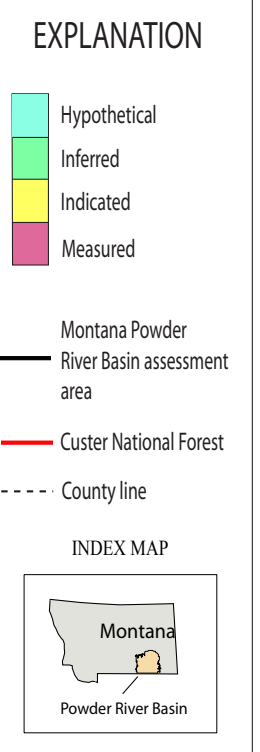

Figure 41. Map showing coal resource reliability categories for the Dietz 2 coal bed within the Montana Powder River Basin assessment area. 


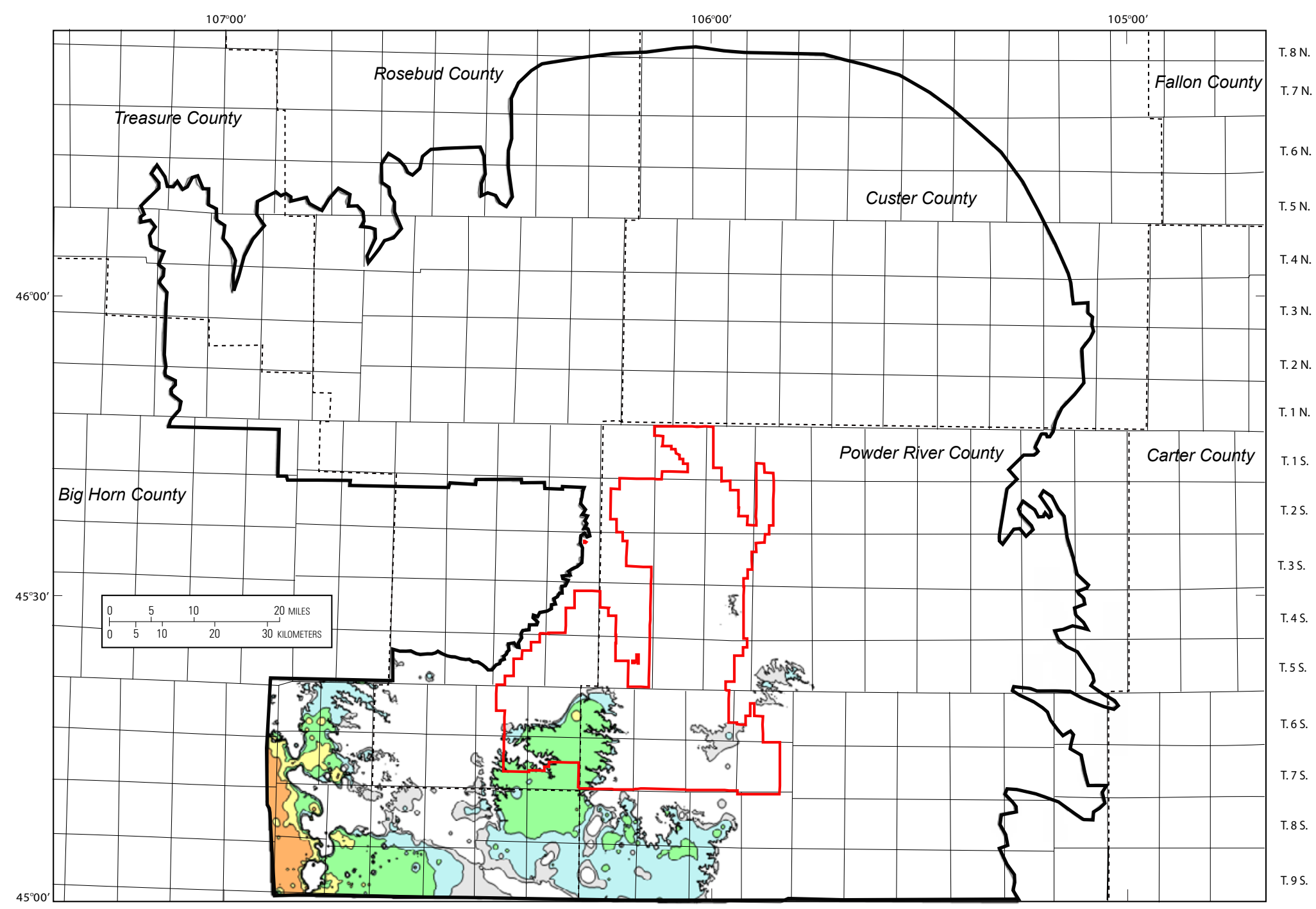

$$
\begin{aligned}
& \text { EXPLANATION } \\
& \text { Thickness (feet) } \\
& \text { Montana Powder } \\
& \text { River Basin assessment } \\
& \text { Custer National Forest } \\
& \text { INDEX MAP } \\
& \text { Montana } \\
& \text { Powder River Basin }
\end{aligned}
$$

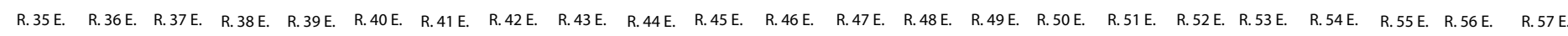

Figure 42. Isopachs showing extent of resources at least 2.5 feet thick in the Dietz 3 coal bed within the Montana Powder River Basin assessment area. 


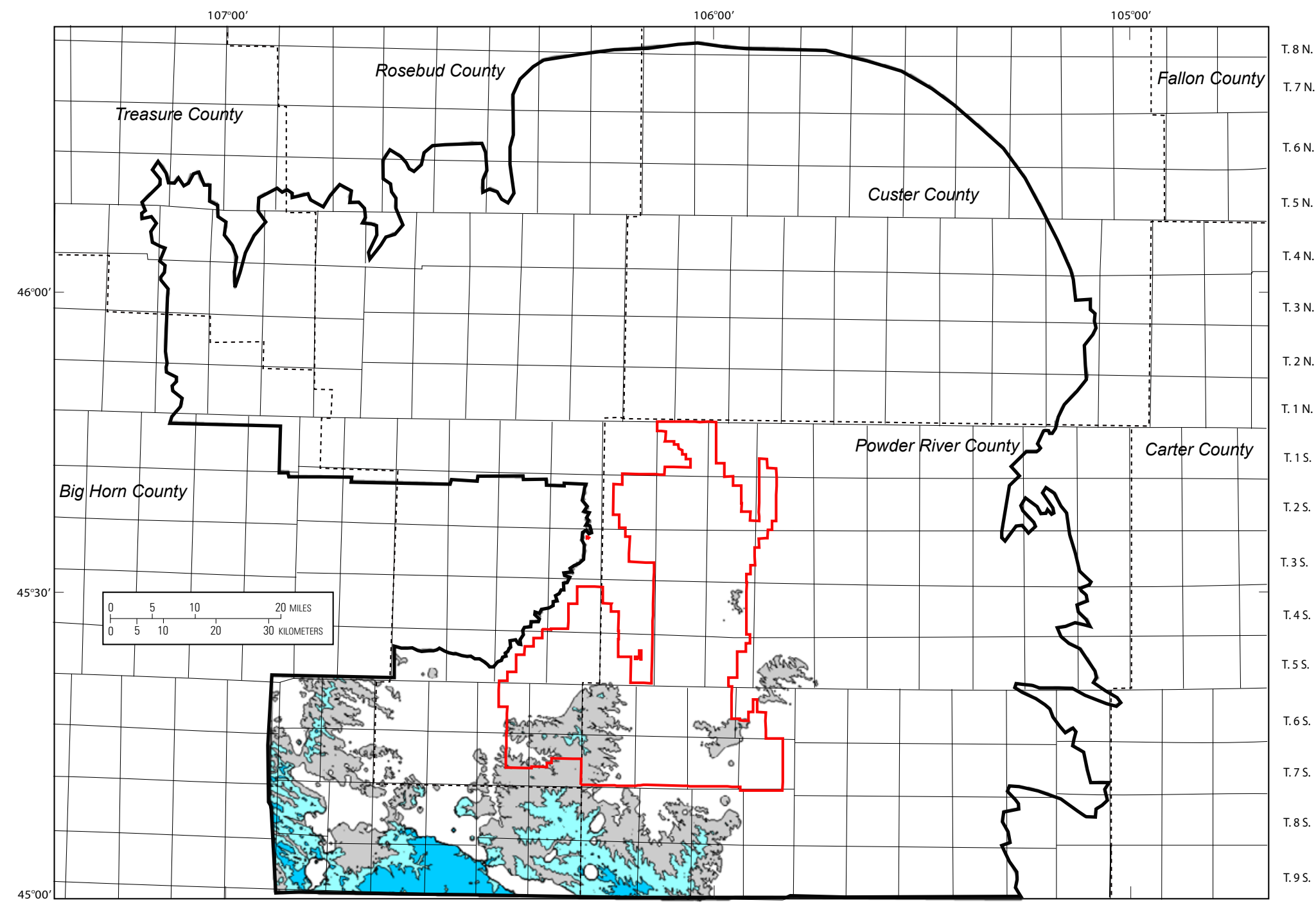

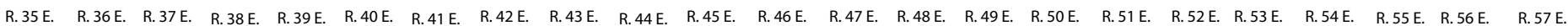

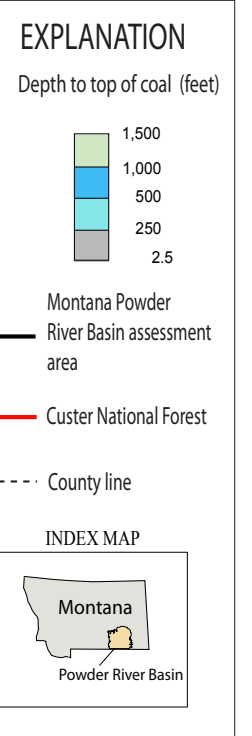

Figure 43. Map showing depth to the top of the Dietz 3 coal bed within the Montana Powder River Basin assessment area. 


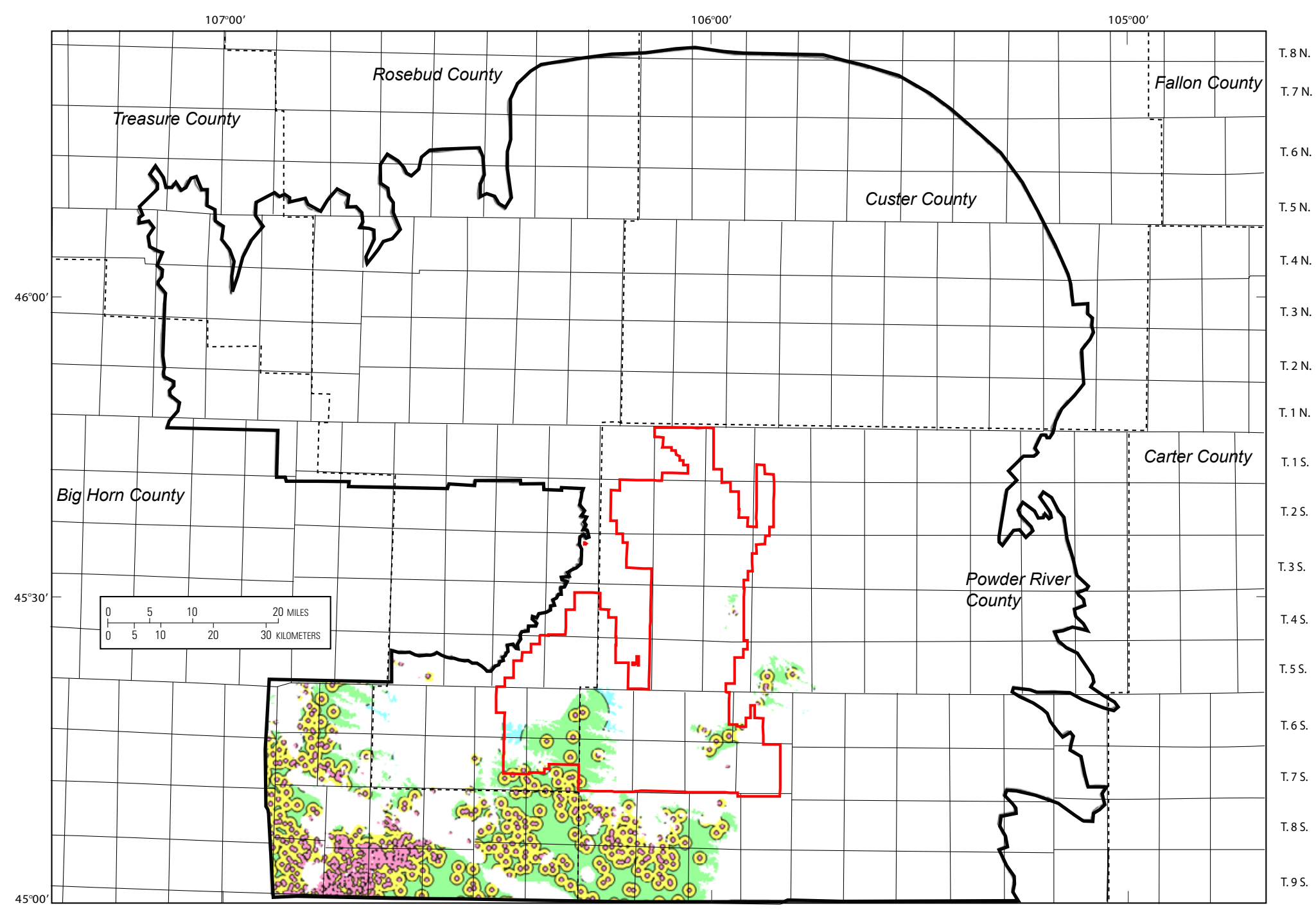

\begin{tabular}{l} 
EXPLANATION \\
\begin{tabular}{|l|l|}
\hline & Hypothetical \\
Inferred \\
Indicated \\
Measured
\end{tabular} \\
Montana Powder \\
River Basin assessment \\
area \\
Custer National Forest \\
INDEX MAP \\
\hline Montana \\
\hline Powder River Basin \\
\hline
\end{tabular}

Figure 44. Map showing coal resource reliability categories for the Dietz 3 coal bed within the Montana Powder River Basin assessment area. 


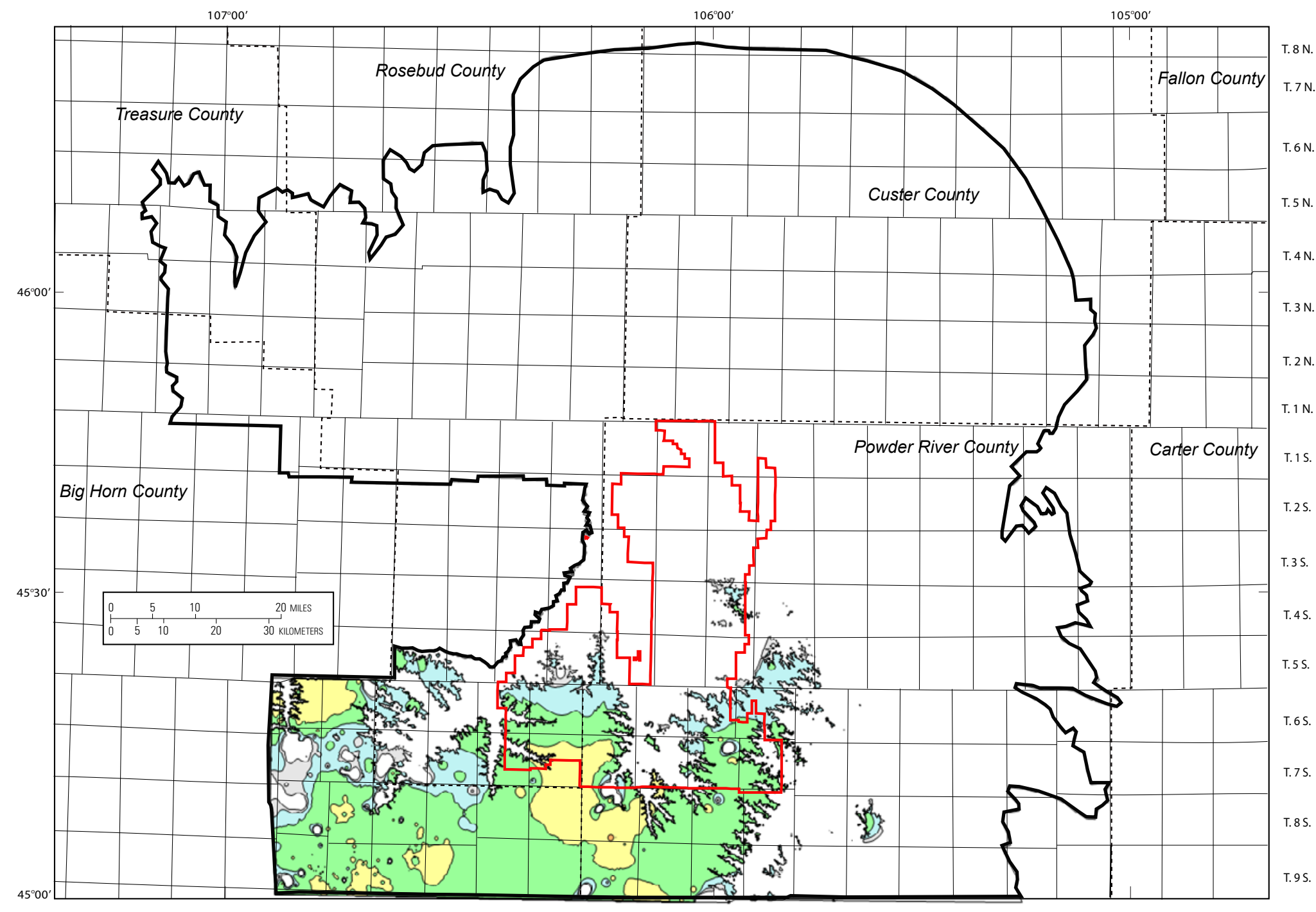

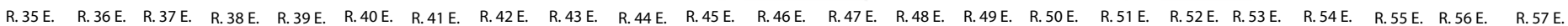

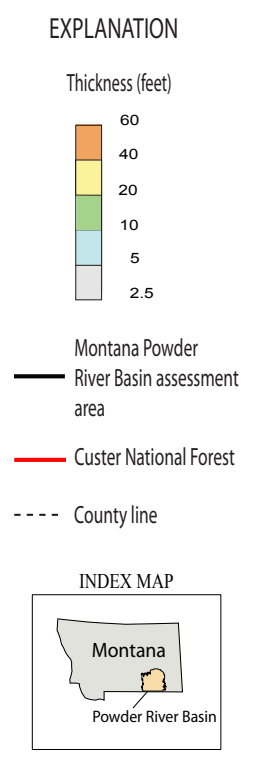

Figure 45. Isopachs showing extent of resources at least 2.5 feet thick in the Canyon coal bed within the Montana Powder River Basin assessment area 


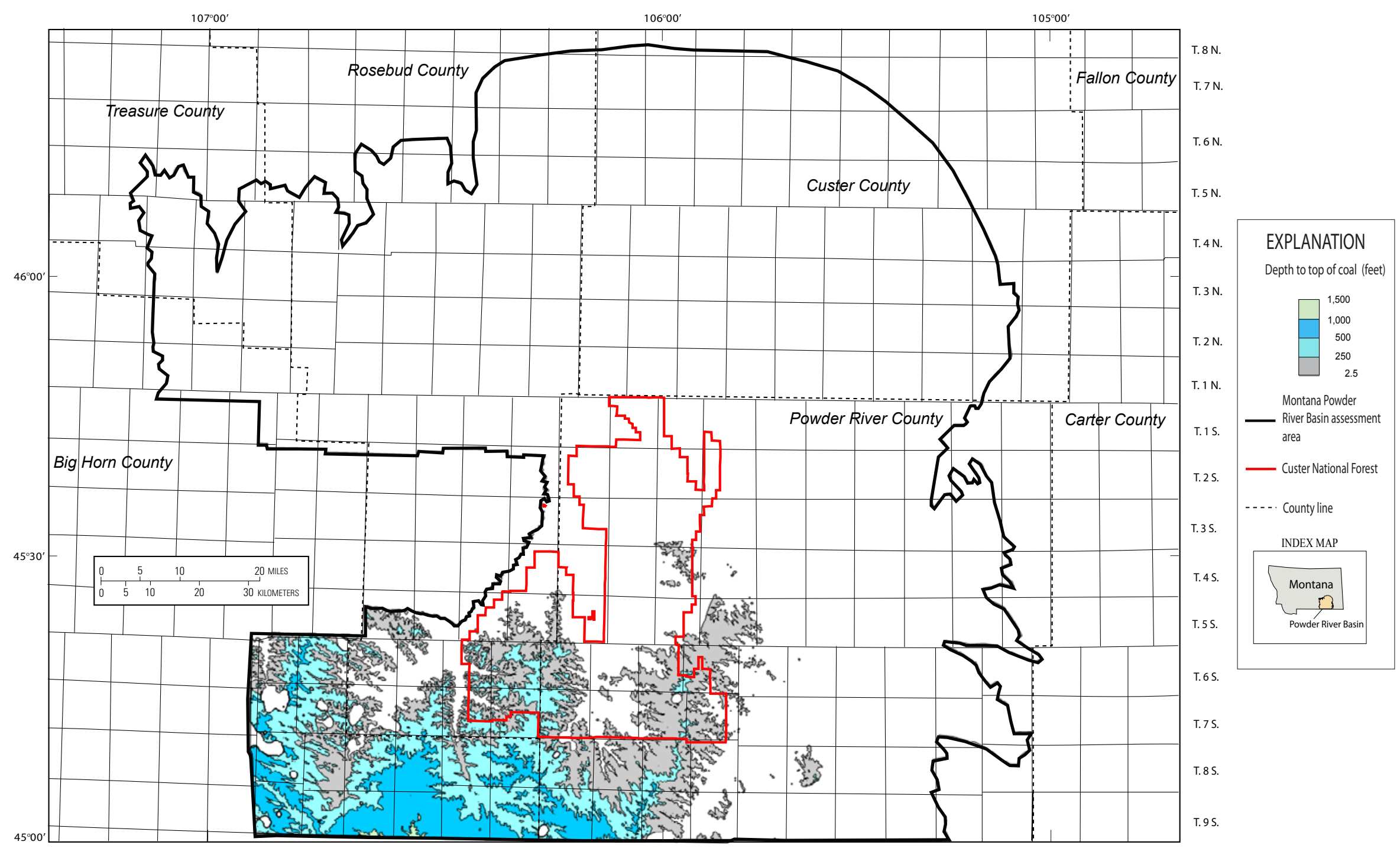

Figure 46. Map showing depth to the top of the Canyon coal bed within the Montana Powder River Basin assessment area. 


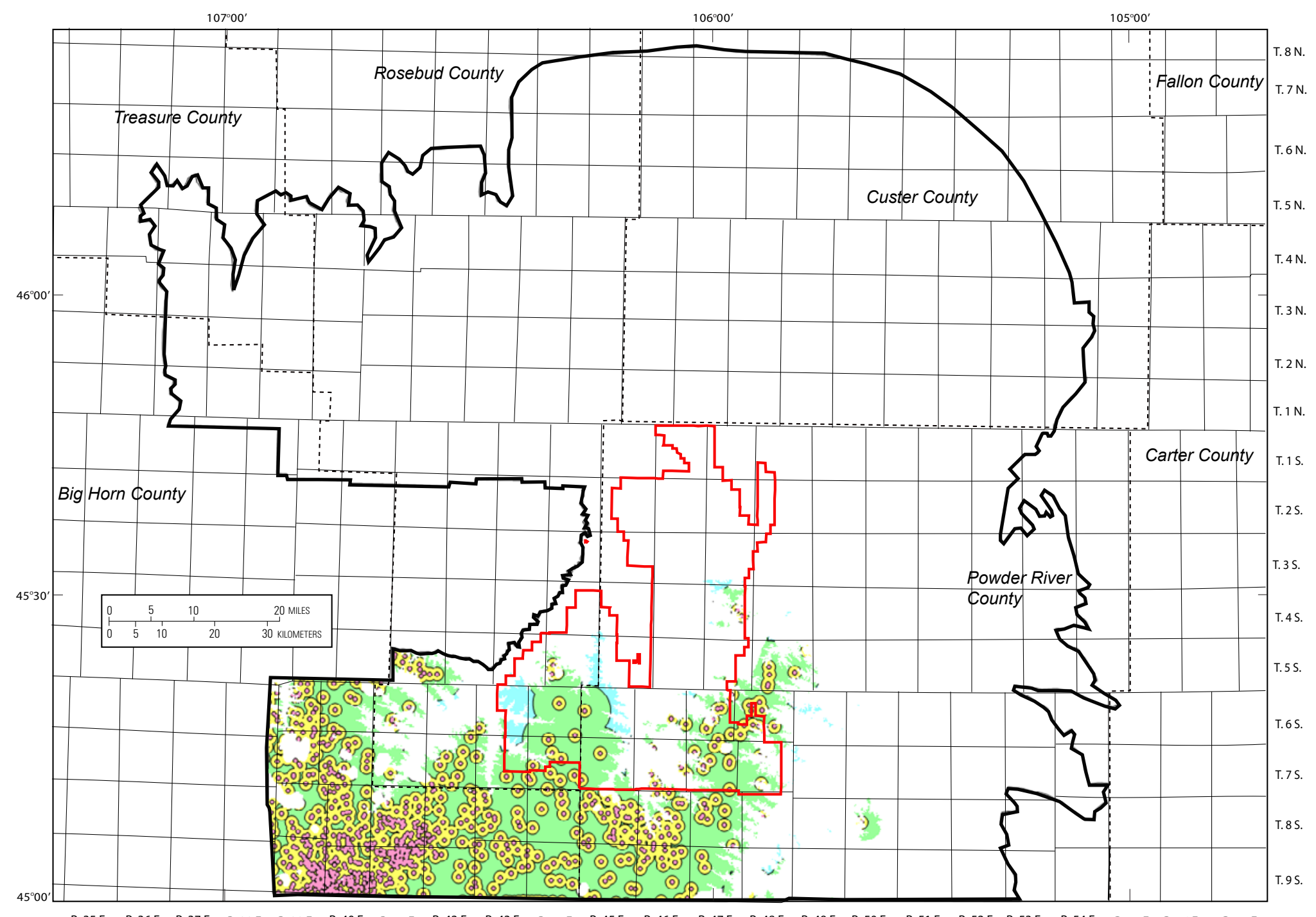

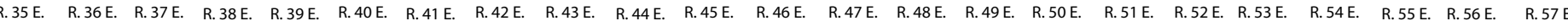

Figure 47. Map showing coal resource reliability categories for the Canyon coal bed within the Montana Powder River Basin assessment area. 

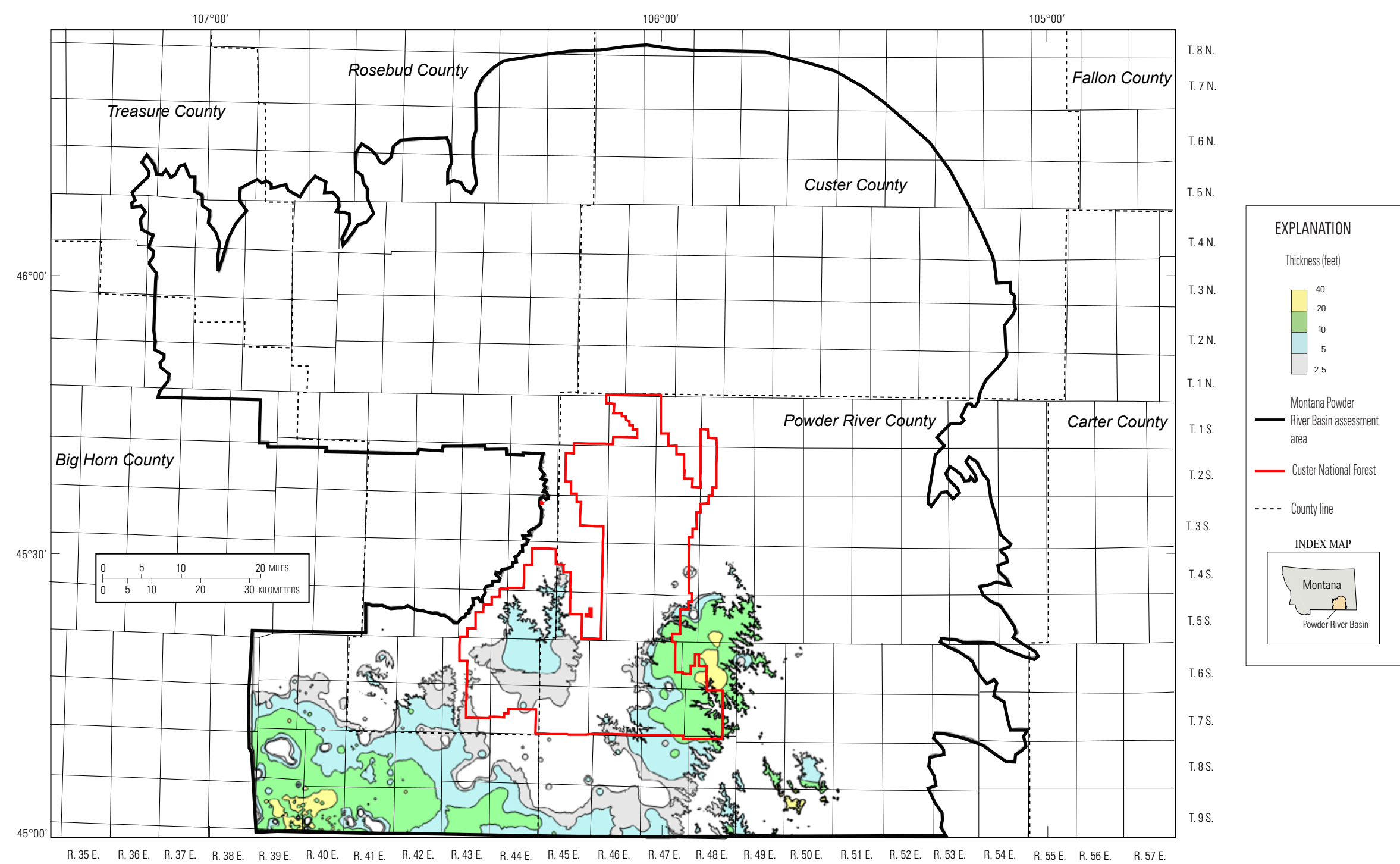

Figure 48. Isopachs showing extent of resources at least 2.5 feet thick in the Lower Canyon coal bed within the Montana Powder River Basin assessment area. 


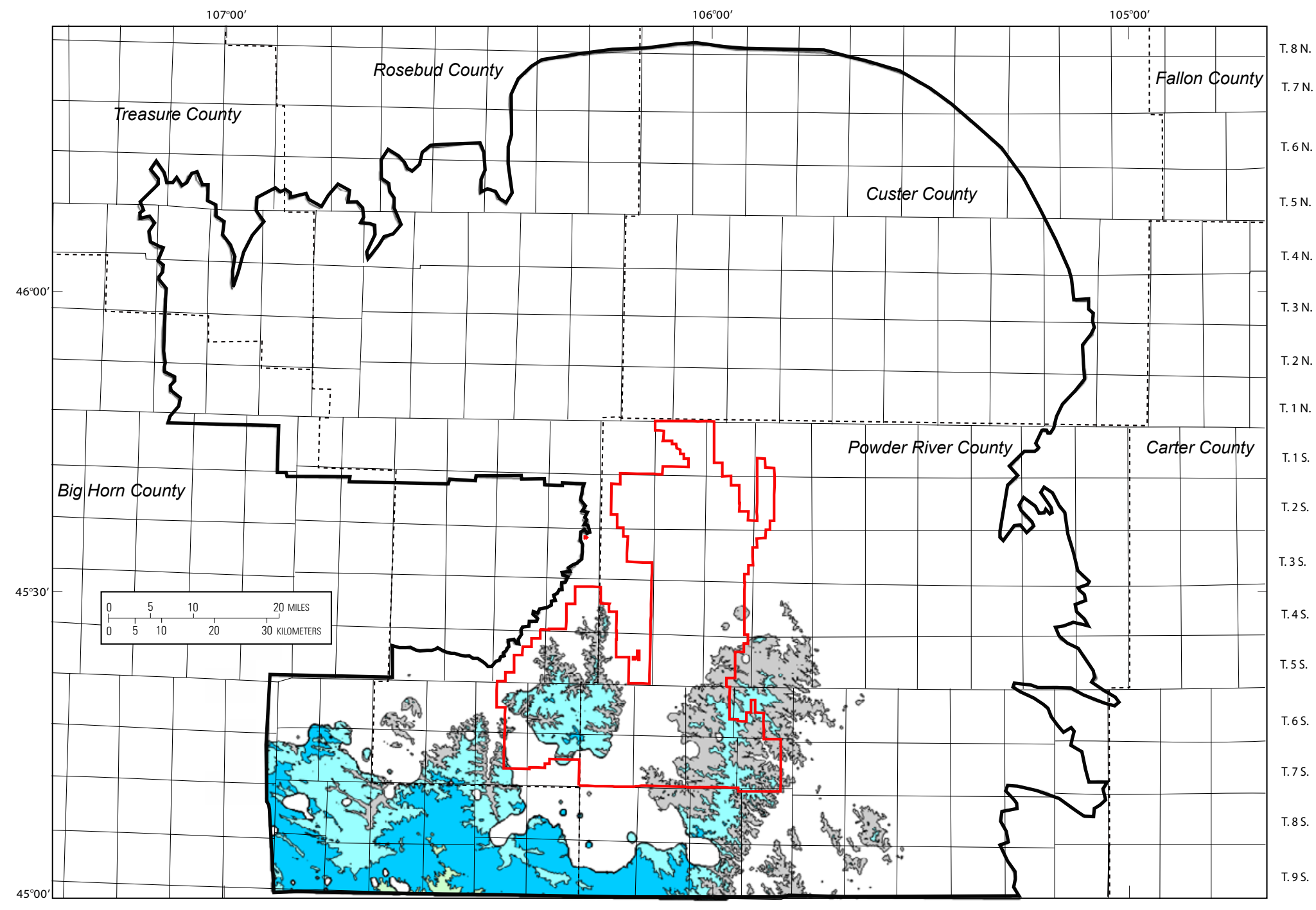

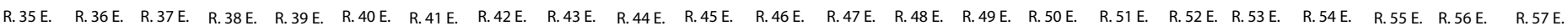

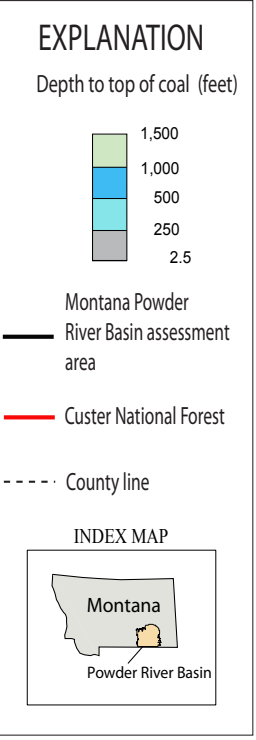

Figure 49. Map showing depth to the top of the Lower Canyon coal bed within the Montana Powder River Basin assessment area. 


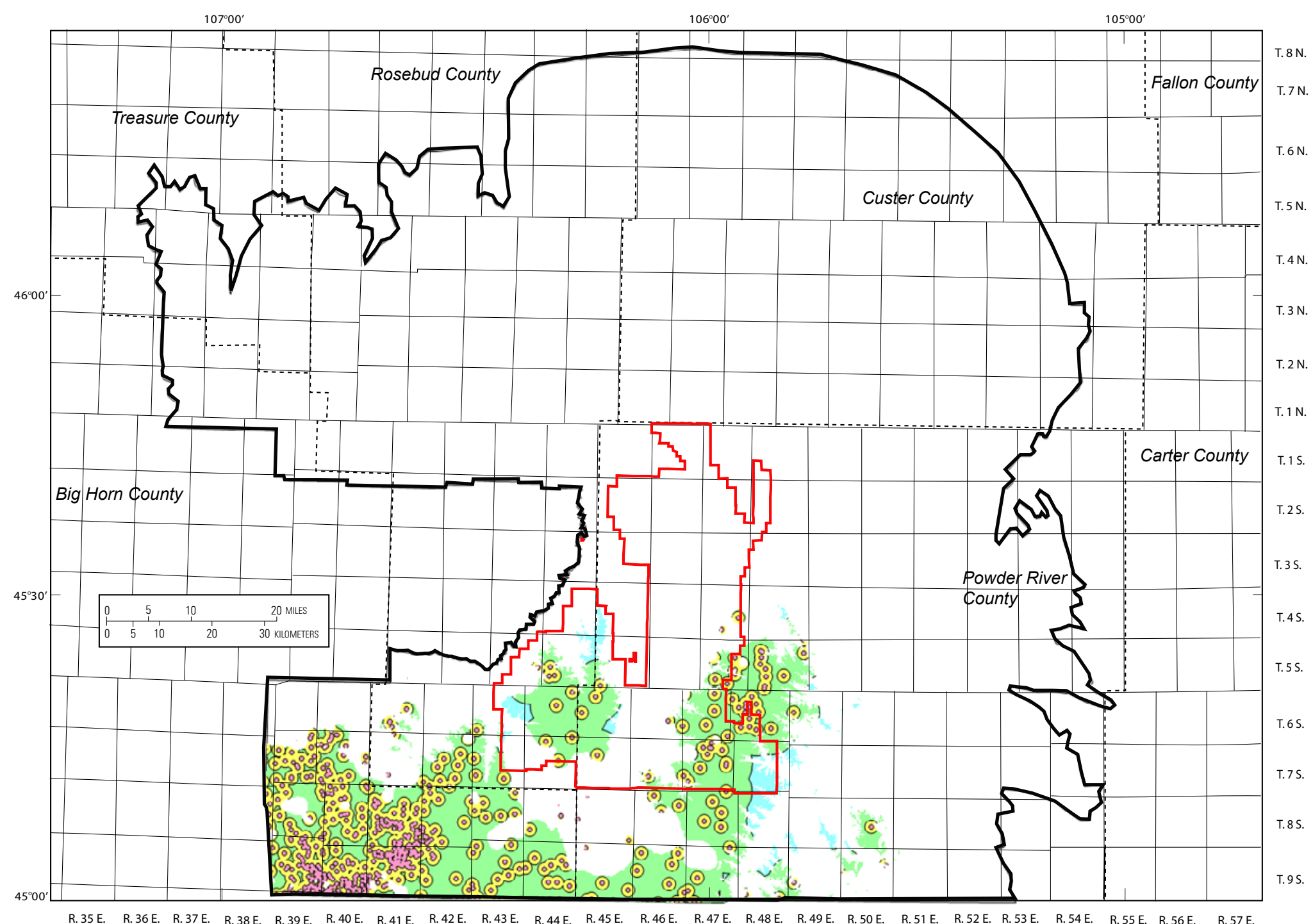

\begin{tabular}{|c|}
\hline EXPLANATION \\
\hline Hypothetical \\
\hline Inferred \\
\hline Indicated \\
\hline Measured \\
\hline $\begin{array}{l}\text { Montana Powder } \\
\text { - River Basin assessment } \\
\text { area }\end{array}$ \\
\hline Custer National Forest \\
\hline County line \\
\hline INDEX MAP \\
\hline Montana \\
\hline Powder River Basin \\
\hline
\end{tabular}

Figure 50. Map showing coal resource reliability categories for the Lower Canyon coal bed within the Montana Powder River Basin assessment area. 

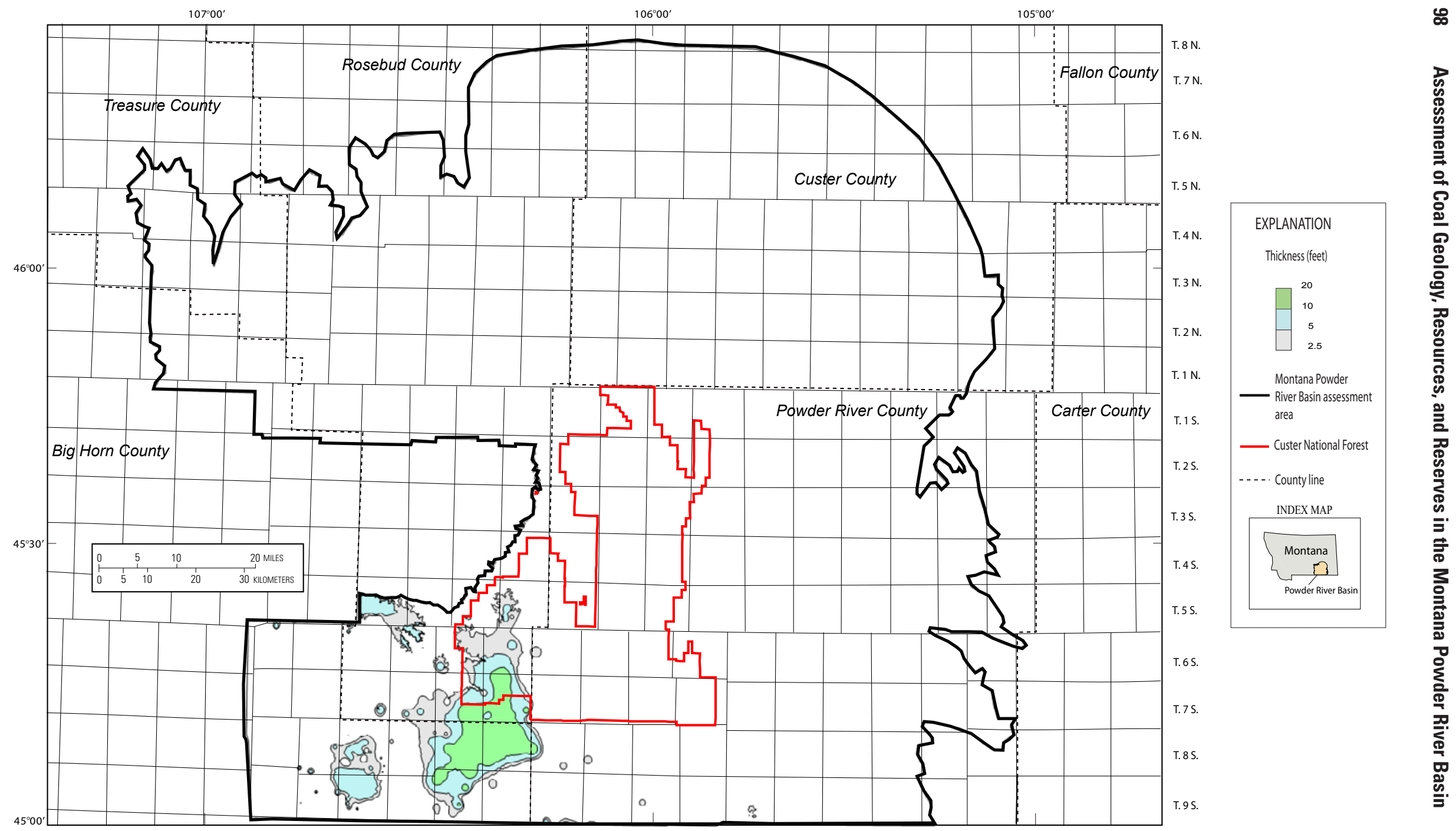

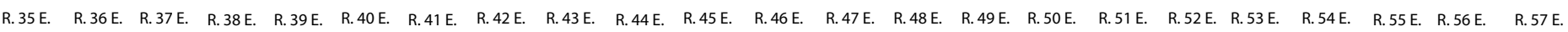

Figure 51. Isopachs showing extent of resources at least 2.5 feet thick in the Ferry coal bed within the Montana Powder River Basin assessment area. 


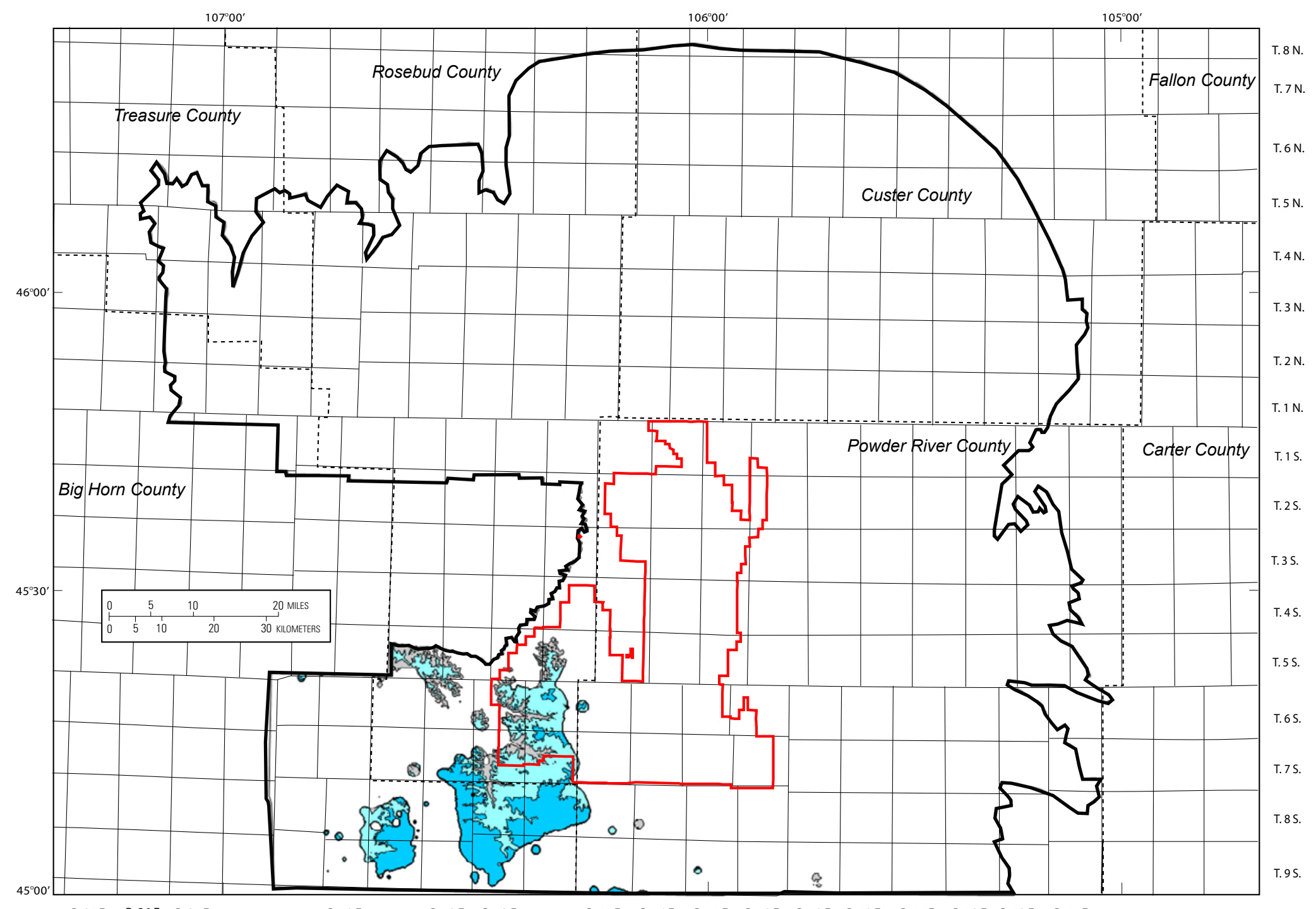

EXPLANATION

Depth to top of coal (feet)

$\square^{1,500}$

\begin{tabular}{r}
1,000 \\
\hline \\
500
\end{tabular}

$\begin{array}{r}250 \\ -\quad 2.5 \\ \hline\end{array}$

Montana Powder

River Basin assessment

area

— Custer National Forest

..... County line

INDEX MAP

Montana
$\square$

Powder River Basin

R. 35 E. R. 36 E. R. 37 E. R. 38 E. R. 39 E. R. 40 E. R. 41 E. R. R. 42 E. R. 43 E. R. 44 E. R. 45 E. R. 46 E. R. 47 E. R. 48 E. R. 49 E. R. 50 E. R. 51 E. R. 52 E. R. 53 E. R. 54 E. R. .55 E. R. 56 E. R. 57 E.

Figure 52. Map showing depth to the top of the Ferry coal bed within the Montana Powder River Basin assessment area. 


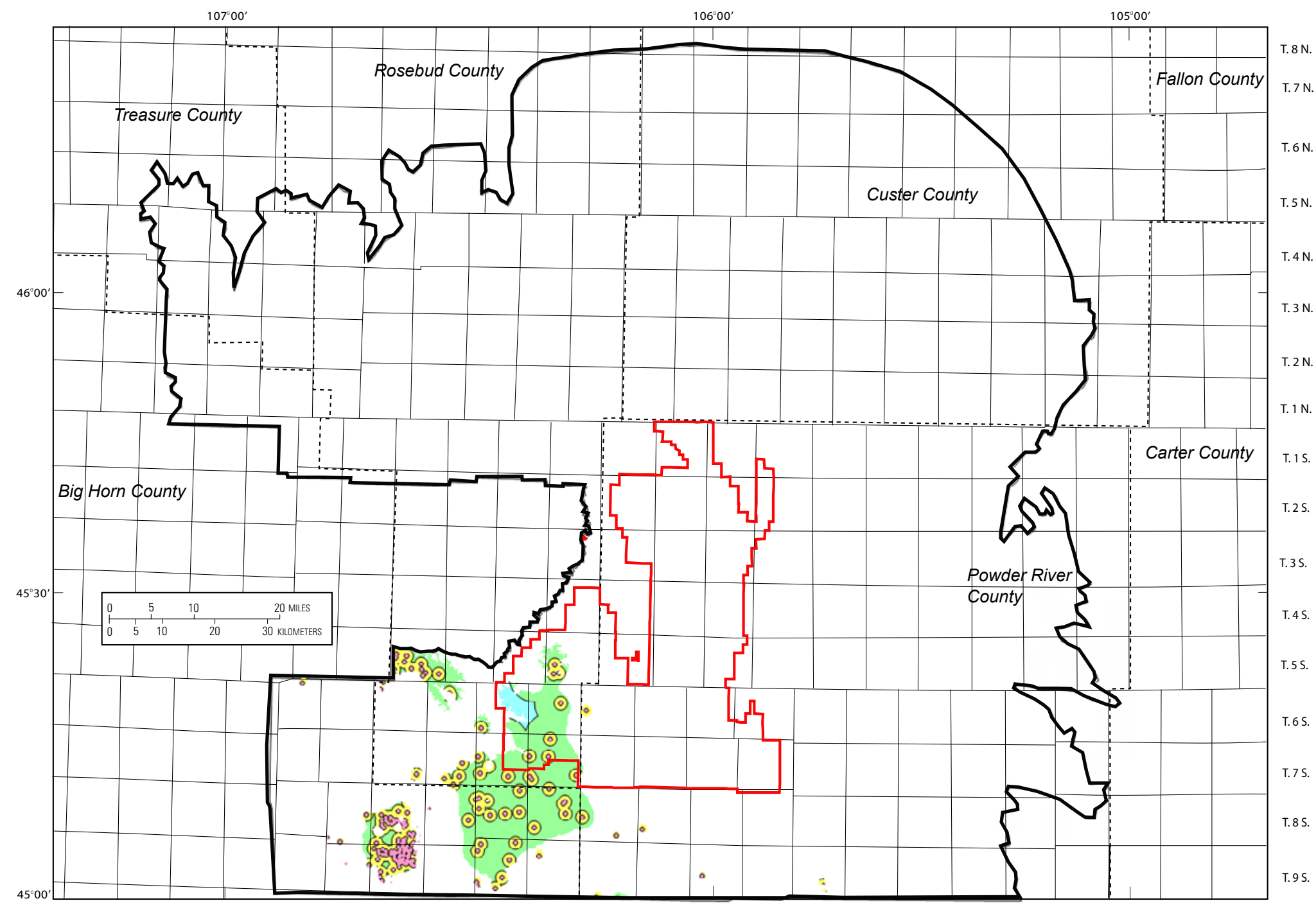

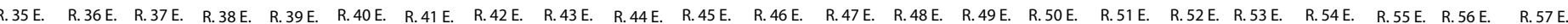

\begin{tabular}{c} 
EXPLANATION \\
$\begin{array}{l}\text { Hypothetical } \\
\text { Inferred } \\
\text { Indicated } \\
\text { Measured }\end{array}$ \\
\\
Montana Powder \\
River Basin assessment \\
area \\
\hline Custer National Forest \\
-... County line \\
INDEX MAP \\
\hline $\begin{array}{l}\text { Montana } \\
\text { Powder River Basin }\end{array}$ \\
\hline
\end{tabular}

Figure 53. Map showing coal resource reliability categories for the Ferry coal bed within the Montana Powder River Basin assessment area. 

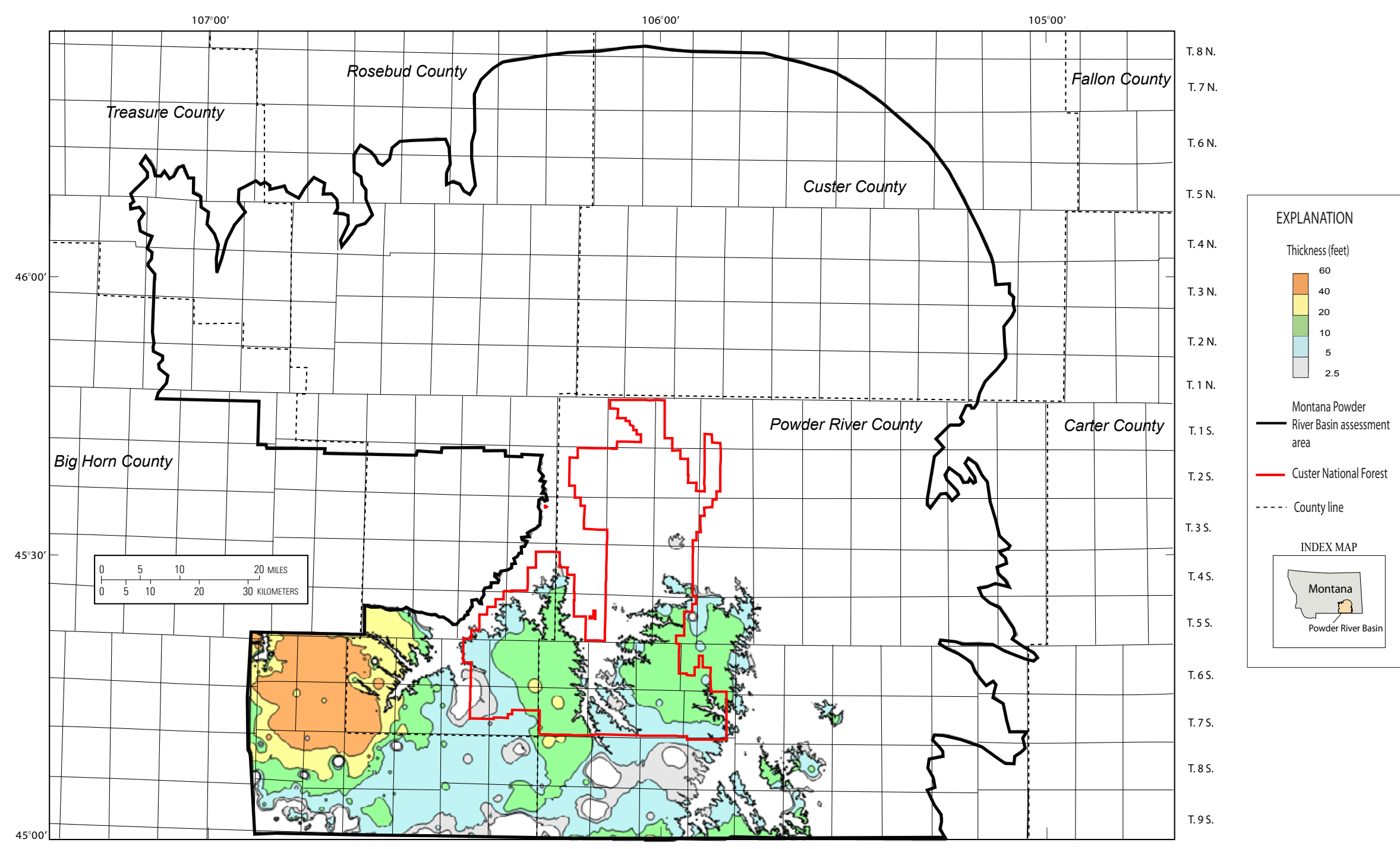

Figure 54. Isopachs showing extent of resources at least 2.5 feet thick in the Werner/Cook coal bed within the Montana Powder River Basin assessment area. 


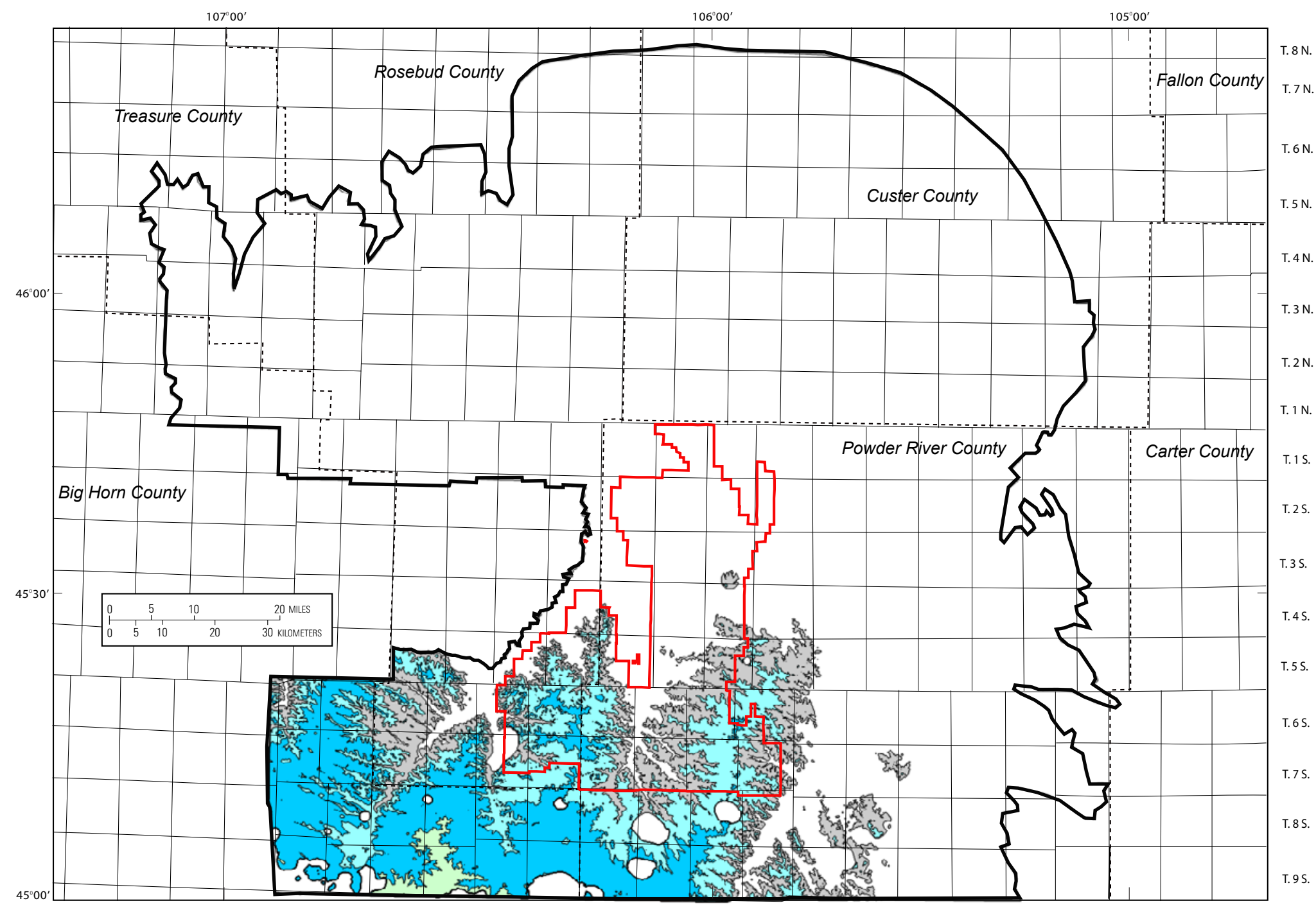

R. 35 E. R. 36 E. R. 37 E. $\quad$ R. 38 E. R. 39 E. R. 40 E. R. R. 41 E. R. 42 E. R. 43 E. R. 44 E. R. 45 E. R. 46 E. R. 47 E. R. 48 E. R. 49 E. R. 50 E. R. 51 E. R. 52 E. R. 53 E. R. 54 E. R. 55 E. R. 56 E. R. R. 57 E.

Figure 55. Map showing depth to the top of the Werner/Cook coal bed within the Montana Powder River Basin assessment area. 


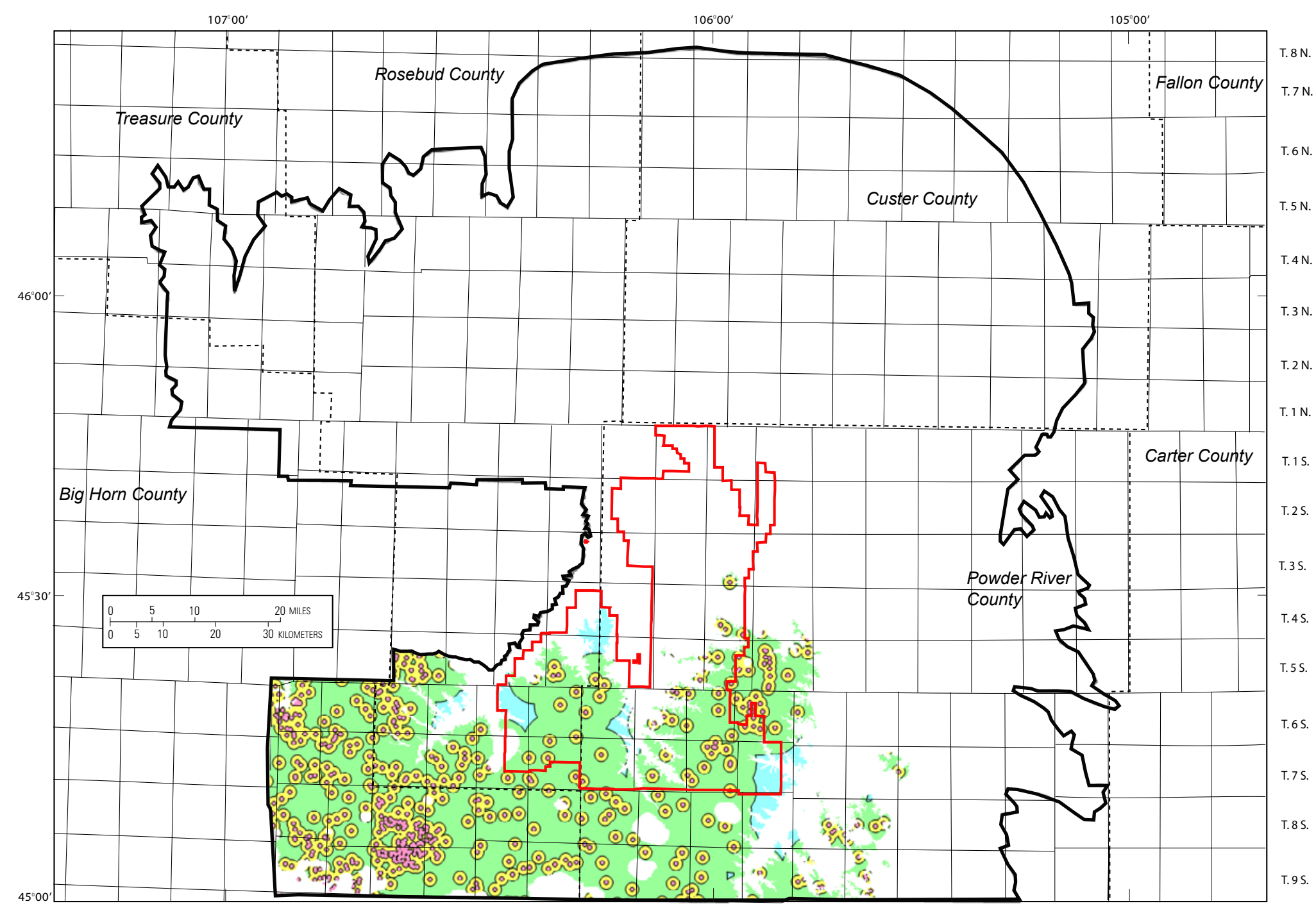

EXPLANATION
\begin{tabular}{l} 
Hypothetical \\
Inferred \\
Indicated \\
Measured \\
Montana Powder \\
River Basin assessment \\
area \\
Custer National Forest \\
INDEX MAP \\
\hline Montana \\
\hline Powder River Basin \\
\hline
\end{tabular}

Figure 56. Map showing coal resource reliability categories for the Werner/Cook coal bed within the Montana Powder River Basin assessment area. 


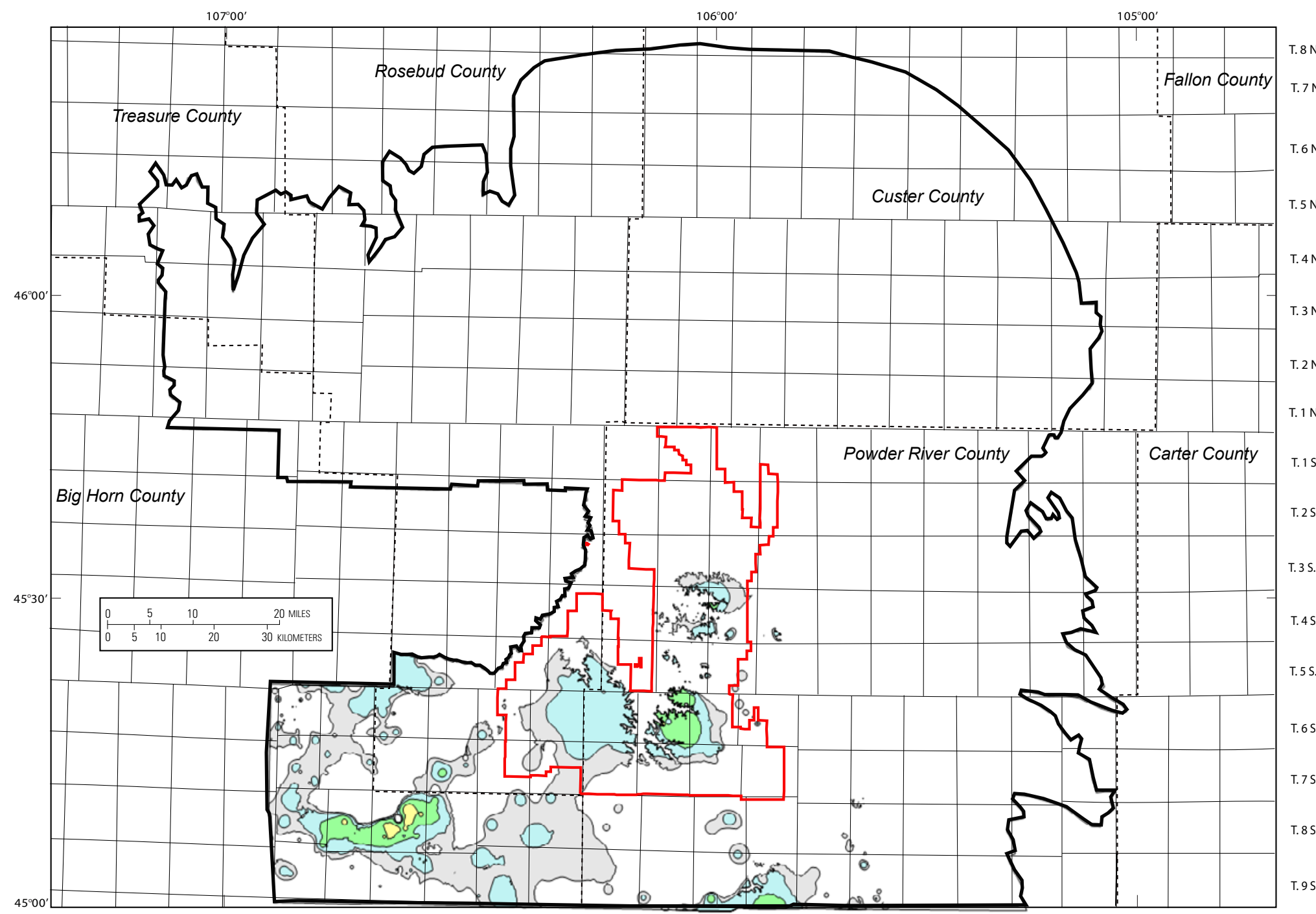

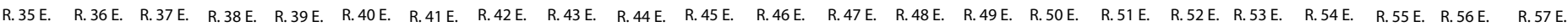

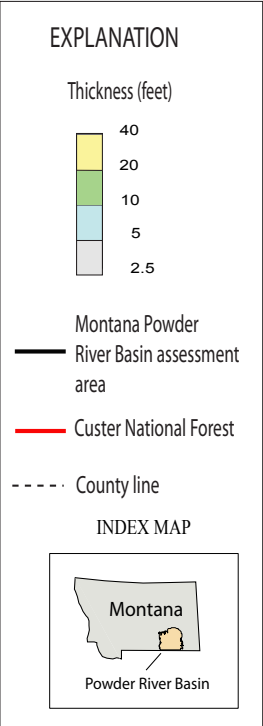

Figure 57. Isopachs showing extent of resources at least 2.5 feet thick in the Otter coal bed within the Montana Powder River Basin assessment area. 


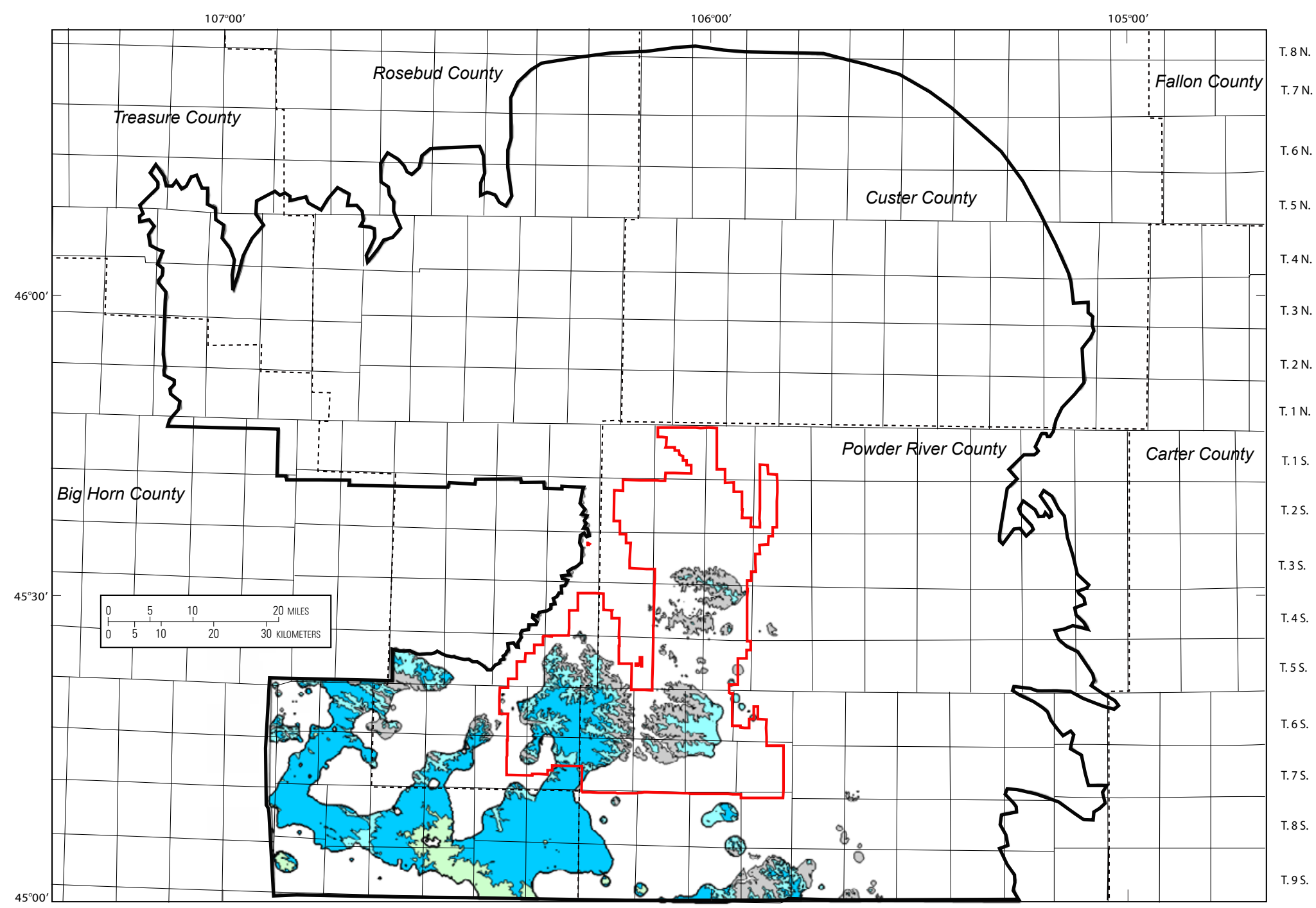

R. 35 E. R. 36 E. R. 37 E. $\quad$ R. 38 E. R. 39 E. R. 40 E. R. 41 E. R. 42 E. R. 43 E. R. R4 E. R. 45 E. R. 46 E. R. R. 47 E. R. 48 E. R. 49 E. R. 50 E. R. R. 51 E. R. 52 E. R. 53 E. R. 54 E. R. 55 E. R. 56 E. R. 57 E.

Figure 58. Map showing depth to the top of the Otter coal bed within the Montana Powder River Basin assessment area. 


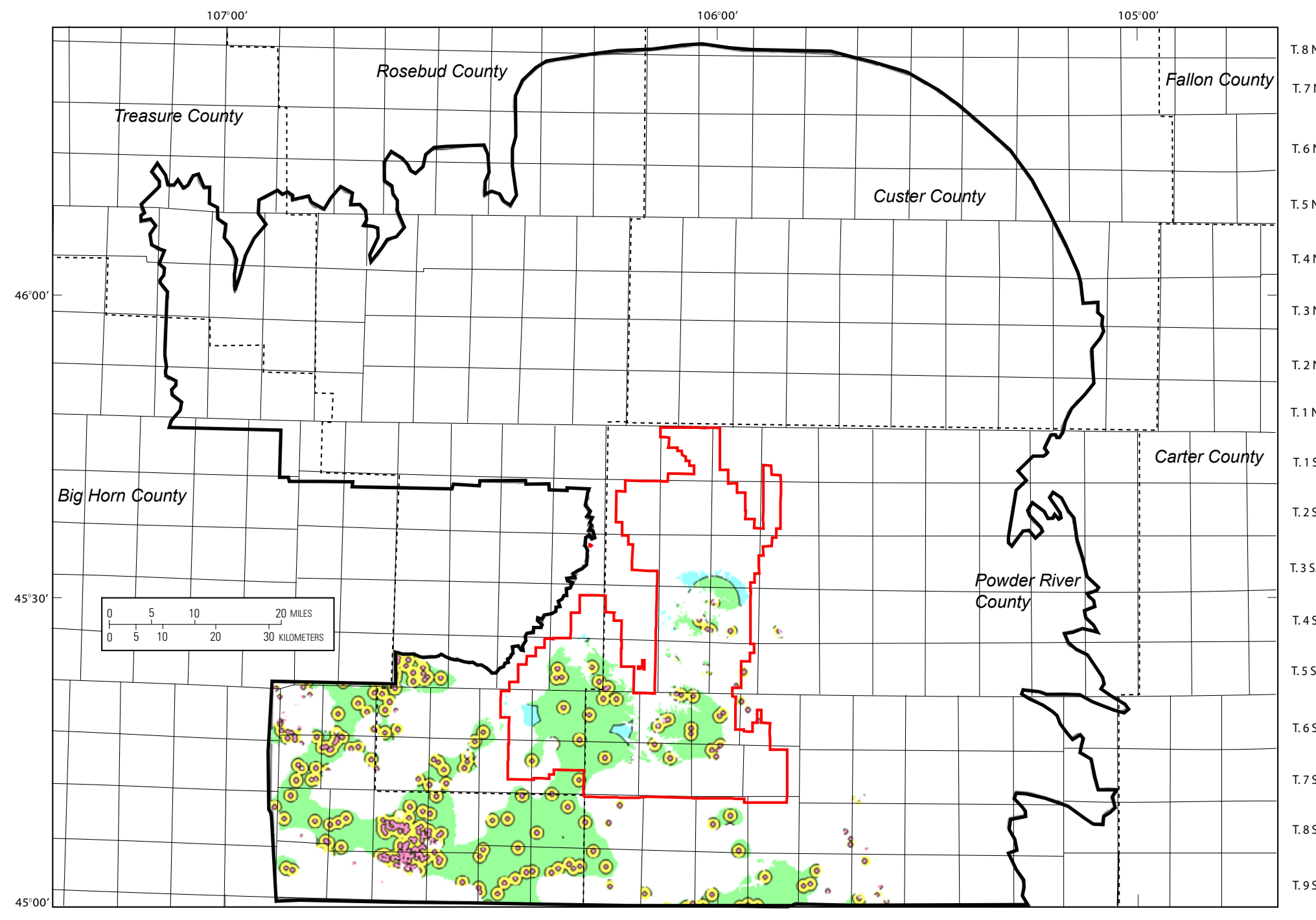

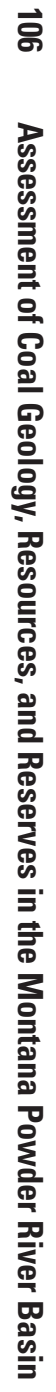

Figure 59. Map showing coal resource reliability categories for the Otter coal bed within the Montana Powder River Basin assessment area. 

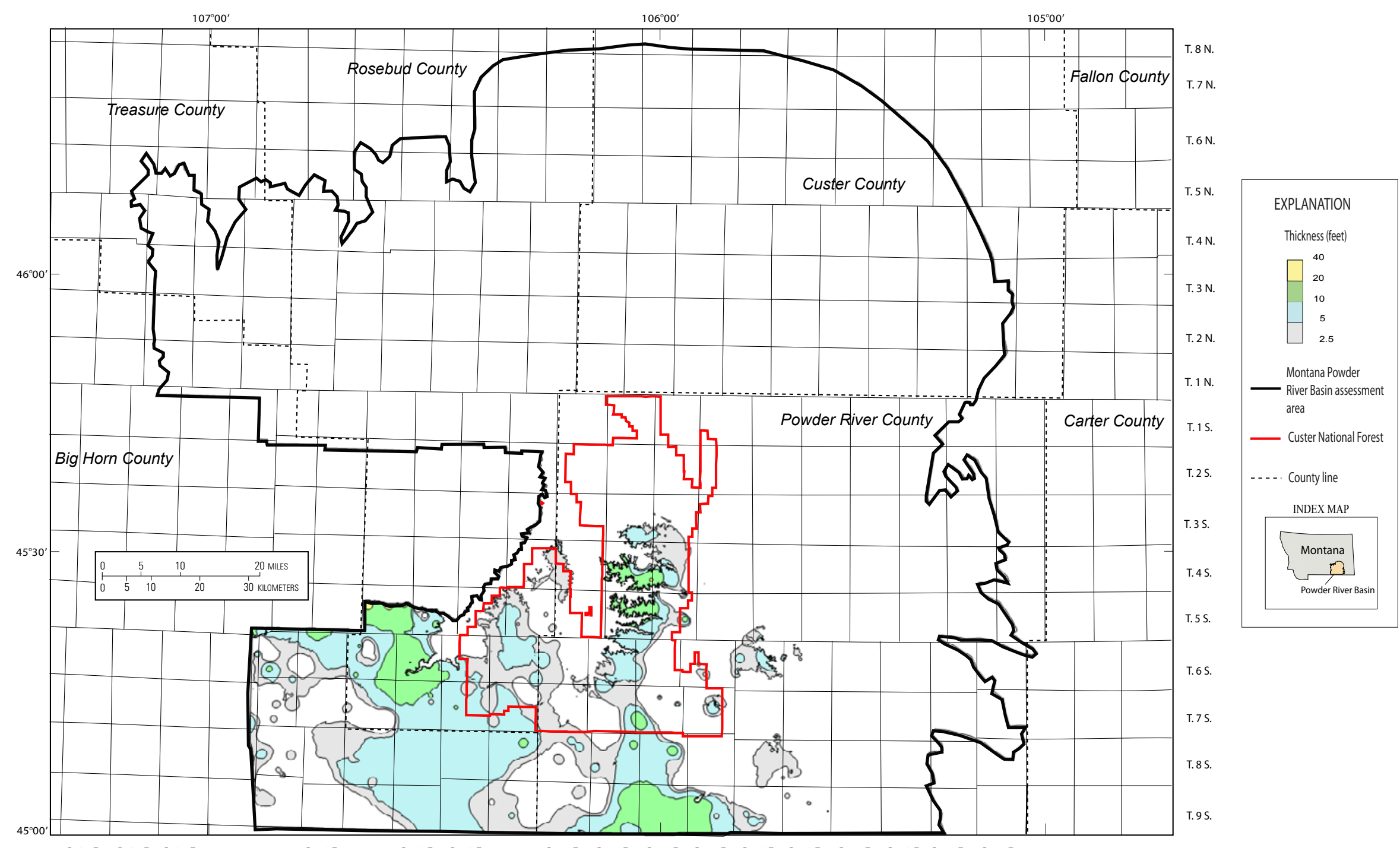

Figure 60. Isopachs showing extent of resources at least 2.5 feet thick in the Gates/Wall coal bed within the Montana Powder River Basin assessment area. 


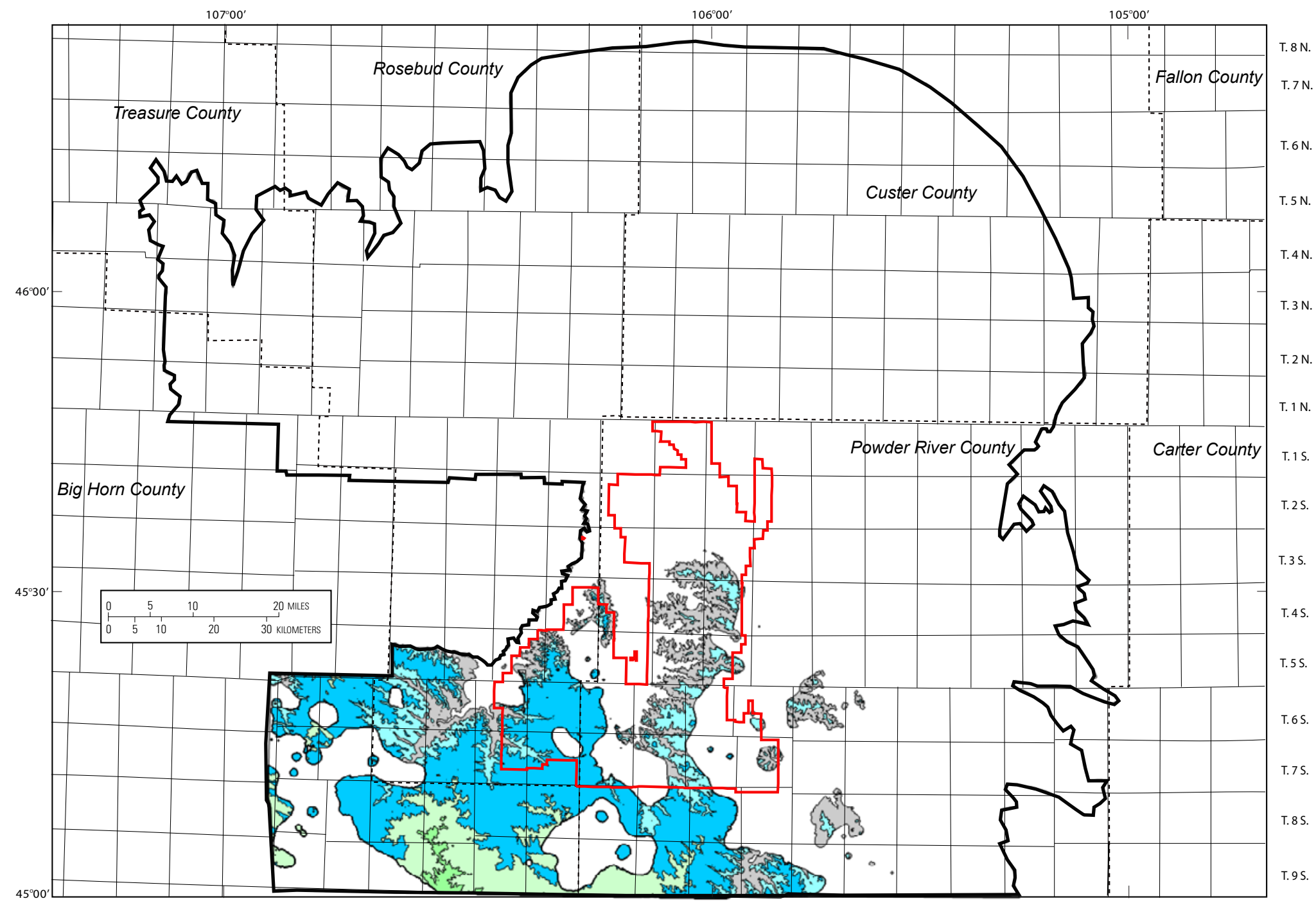

EXPLANATION Depth to top of coal (feet)

1,500
$-1,000$
-500
-250
2.5

Montana Powder

— River Basin assessment

area

— Custer National Forest

-.... County line

INDEX MAP

Montana

Montana
$?$

Powder River Basin

R. 35 E. R. 36 E. R. 37 E. R. 38 E. R. R 39 E. R. 40 E. R. 41 E. R. 42 E. R. 43 E. R. 44 E. R. 45 E. R. 46 E. R. R E. R. 48 E. R. 49 E. R. .50 E. R. 51 E. R. .52 E. R. 53 E. R. R E. R. 55 E. R. R6E. R. .57 E.

Figure 61. Map showing depth to the top of the Gates/Wall coal bed within the Montana Powder River Basin assessment area. 


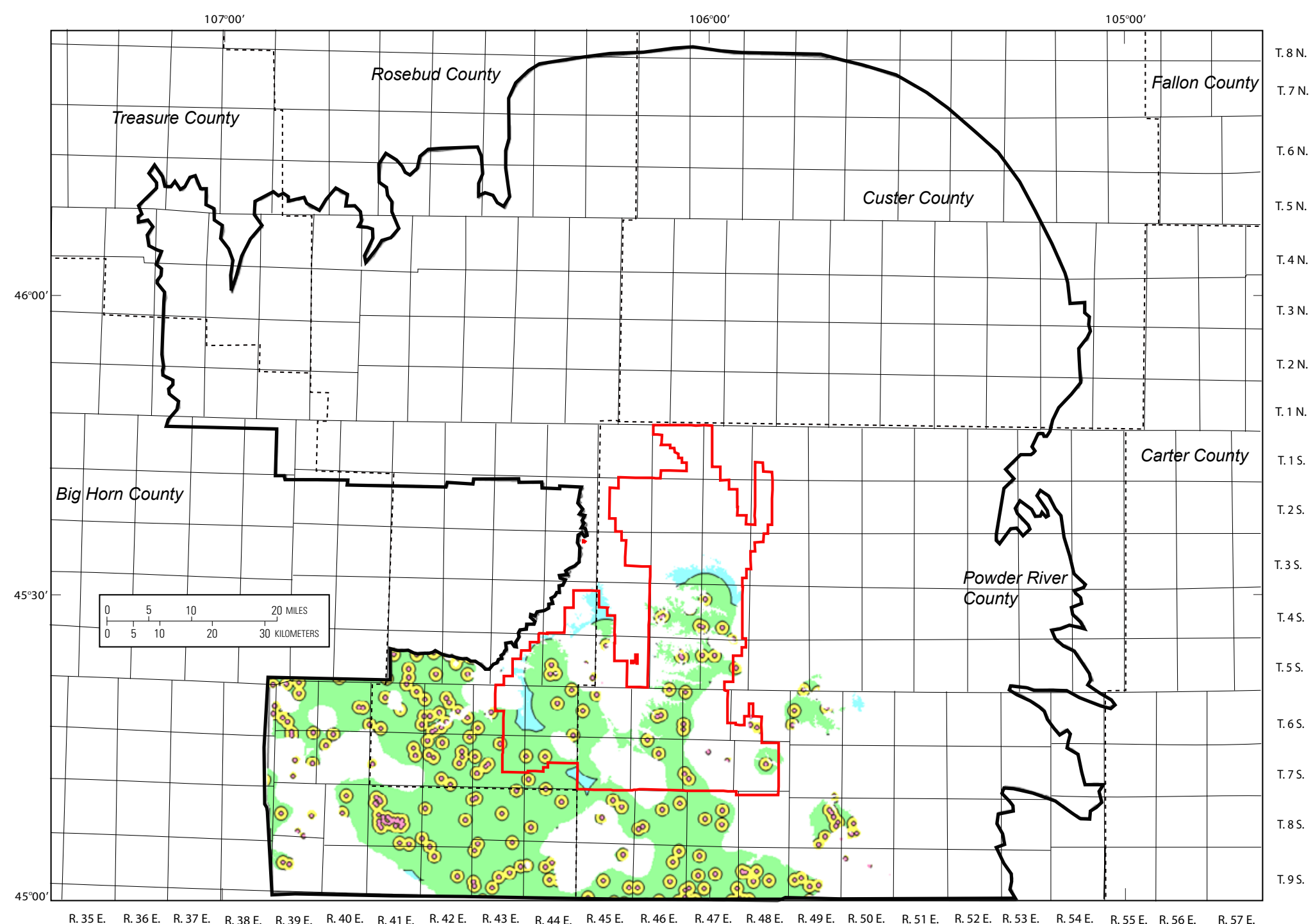

\begin{tabular}{l} 
EXPLANATION \\
\begin{tabular}{|l|l|}
\hline & Hypothetical \\
Inferred \\
Indicated \\
Measured
\end{tabular} \\
Montana Powder \\
River Basin assessment \\
area \\
\hline Custer National Forest \\
\\
INDEX MAP \\
\hline $\begin{array}{c}\text { Montana } \\
\text { Powder River Basin }\end{array}$ \\
\hline
\end{tabular}

Figure 62. Map showing coal resource reliability categories for the Gates/Wall coal bed within the Montana Powder River Basin assessment area. 

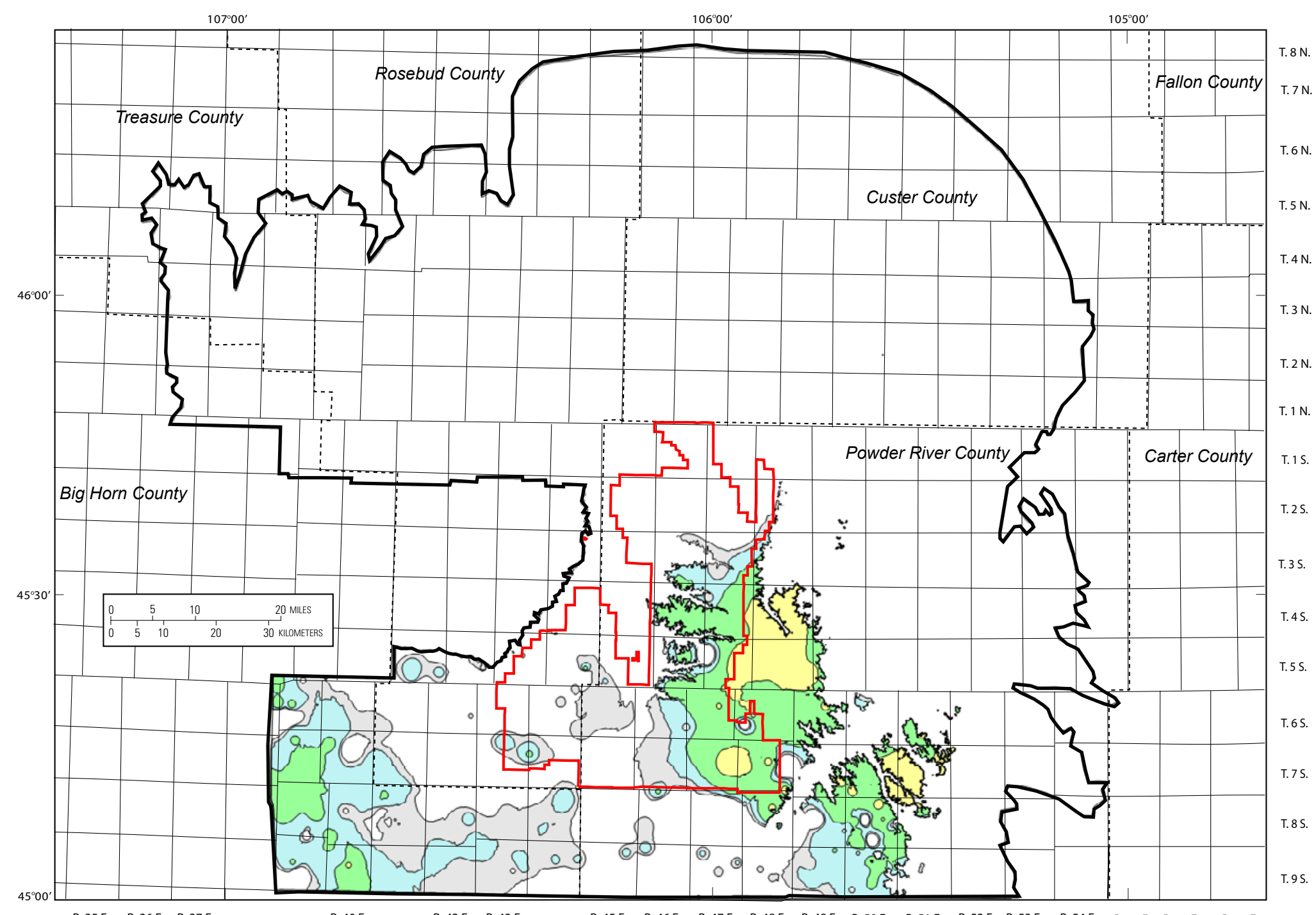

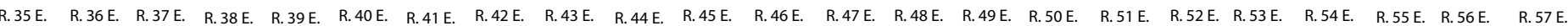

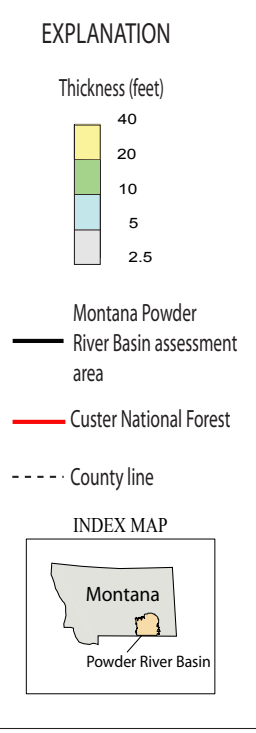

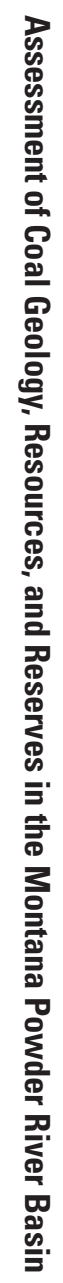

Figure 63. Isopachs showing extent of resources at least 2.5 feet thick in the Pawnee coal bed within the Montana Powder River Basin assessment area. 

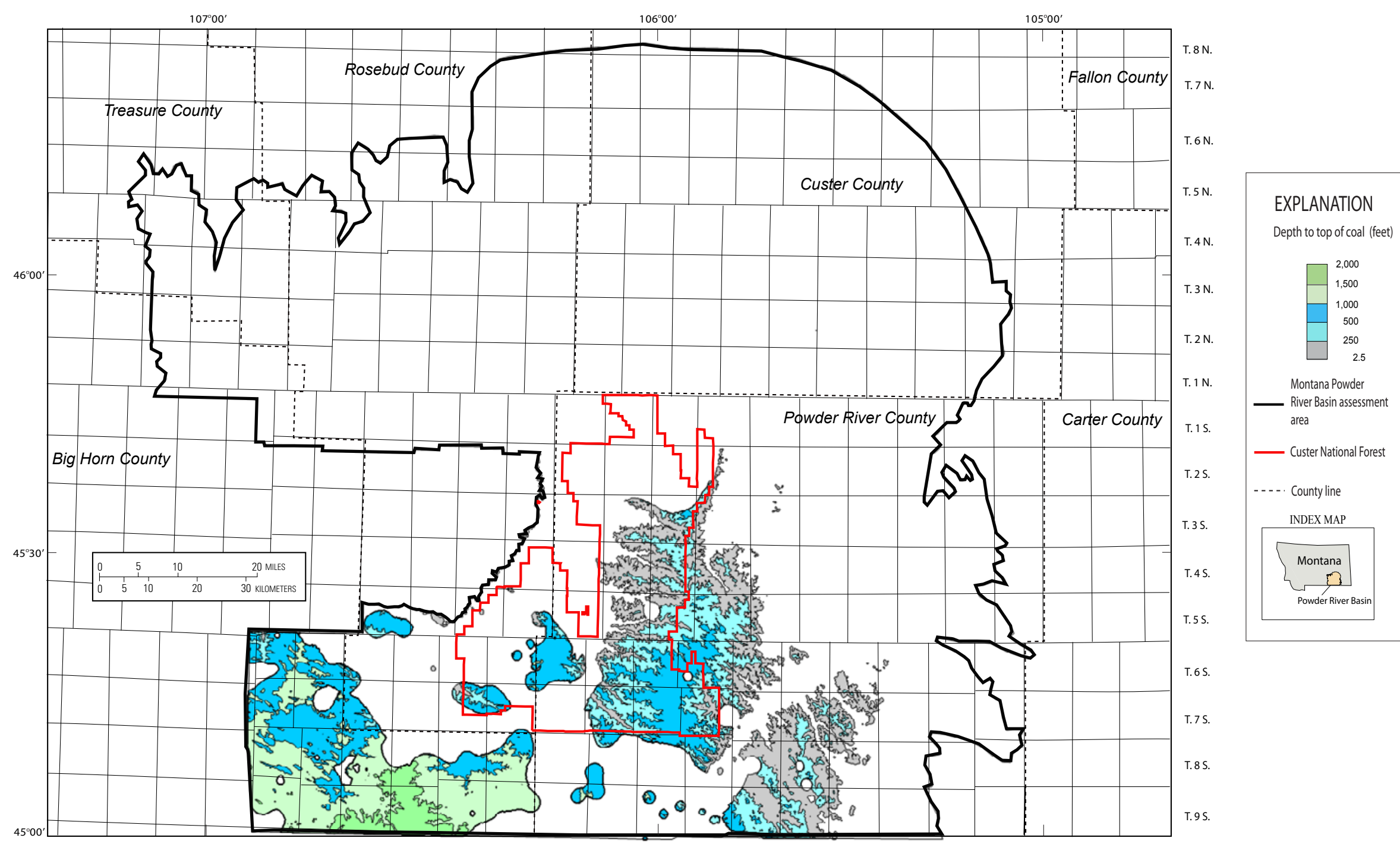

Figure 64. Map showing depth to the top of the Pawnee coal bed within the Montana Powder River Basin assessment area. 


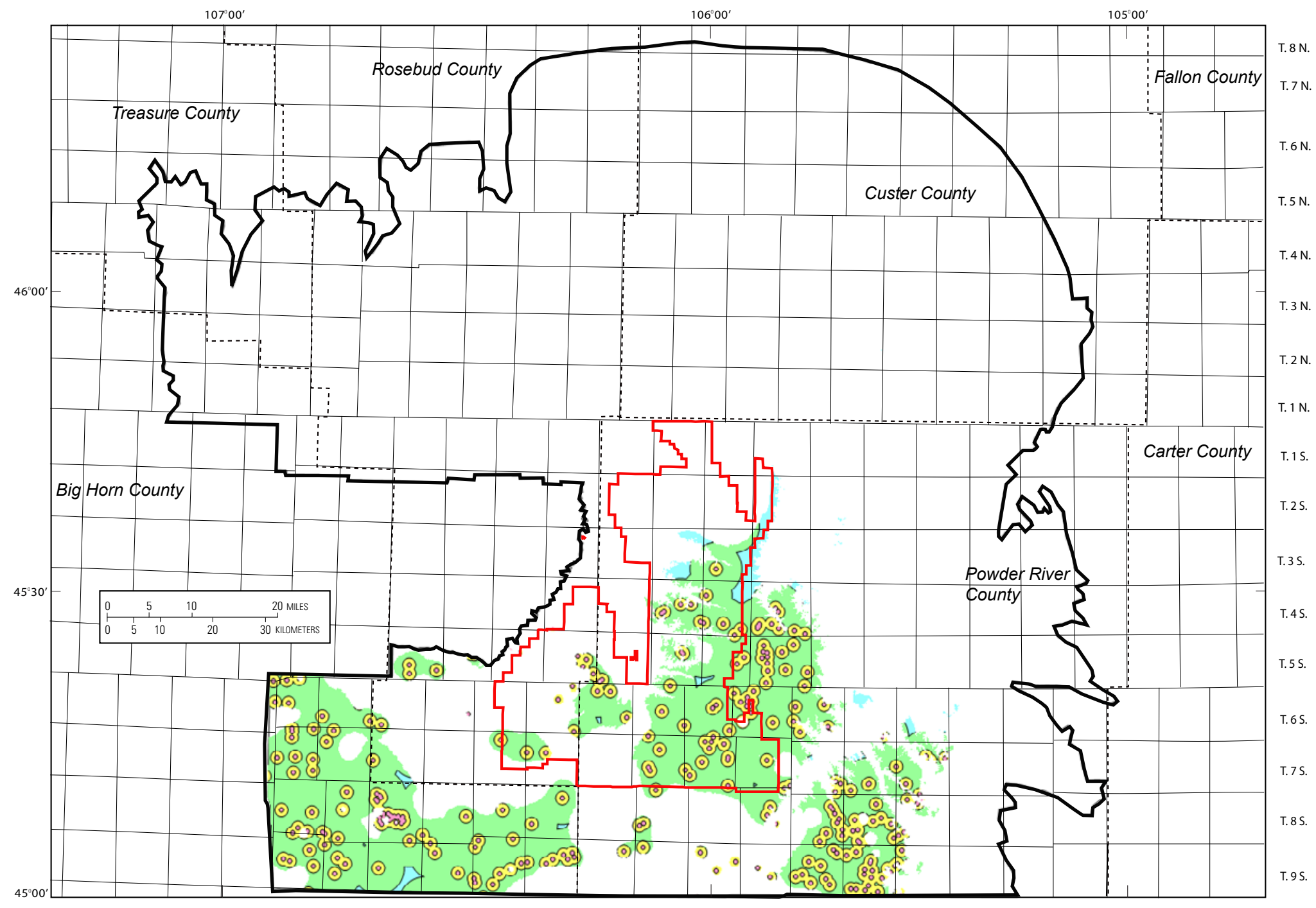

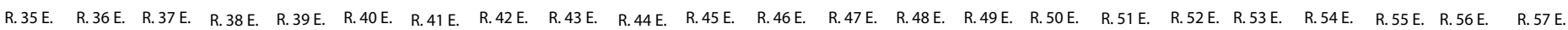

\begin{tabular}{l} 
EXPLANATION \\
$\begin{array}{l}\text { Hypothetical } \\
\text { Inferred } \\
\text { Indicated } \\
\text { Measured }\end{array}$ \\
Montana Powder \\
River Basin assessment \\
area \\
Custer National Forest \\
--.- County line \\
INDEX MAP \\
\hline Montana \\
Powder River Basin \\
\hline
\end{tabular}

Figure 65. Map showing coal resource reliability categories for the Pawnee coal bed within the Montana Powder River Basin assessment area. 


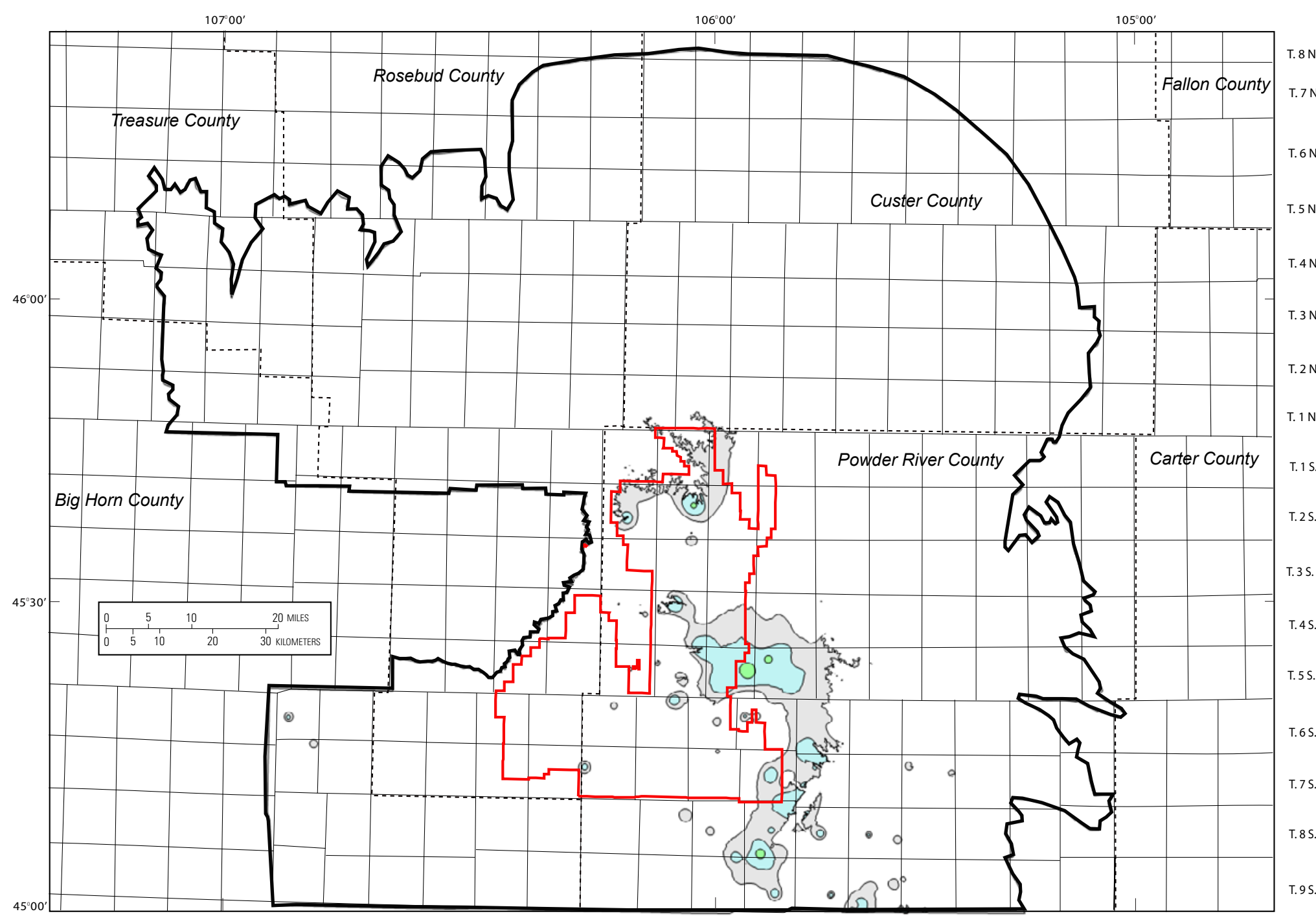

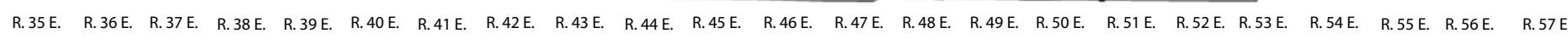

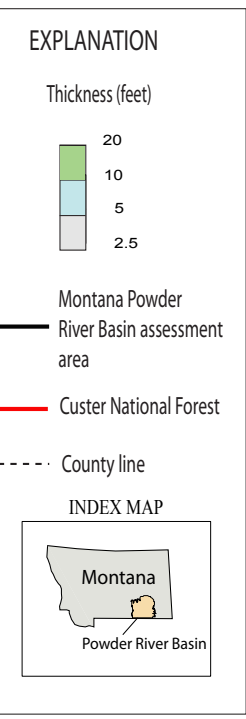

Figure 66. Isopachs showing extent of resources at least 2.5 feet thick in the Odell coal bed within the Montana Powder River Basin assessment area. 


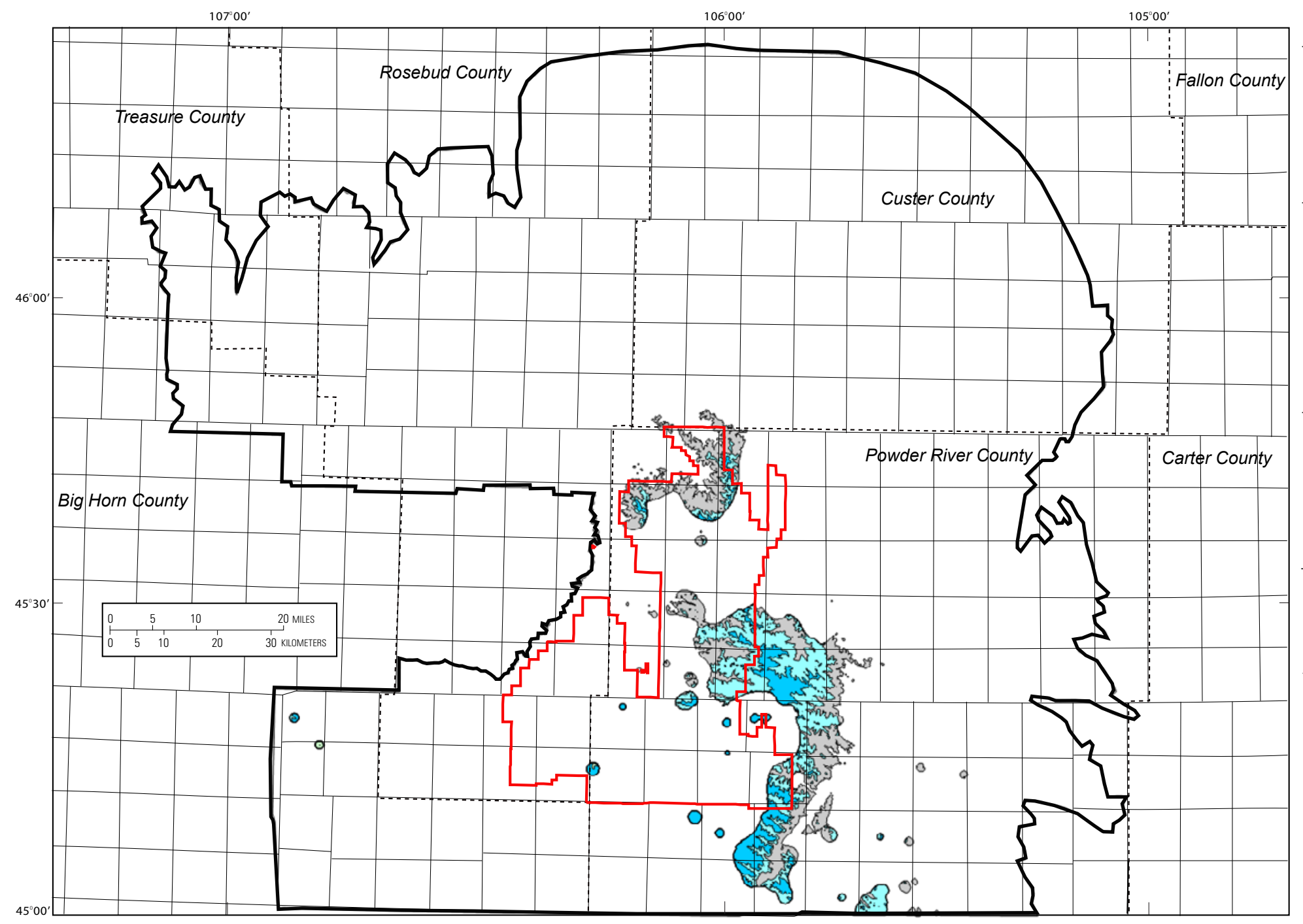

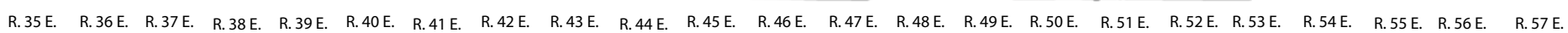

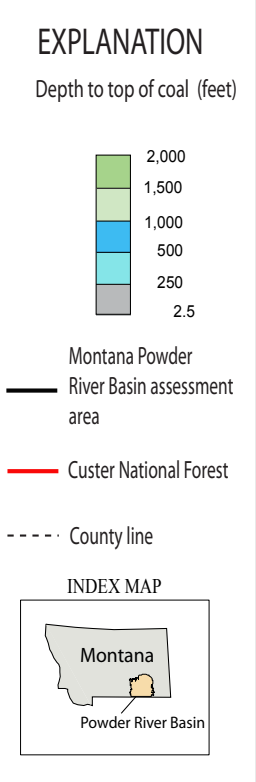

Figure 67. Map showing depth to the top of the Odell coal bed within the Montana Powder River Basin assessment area. 


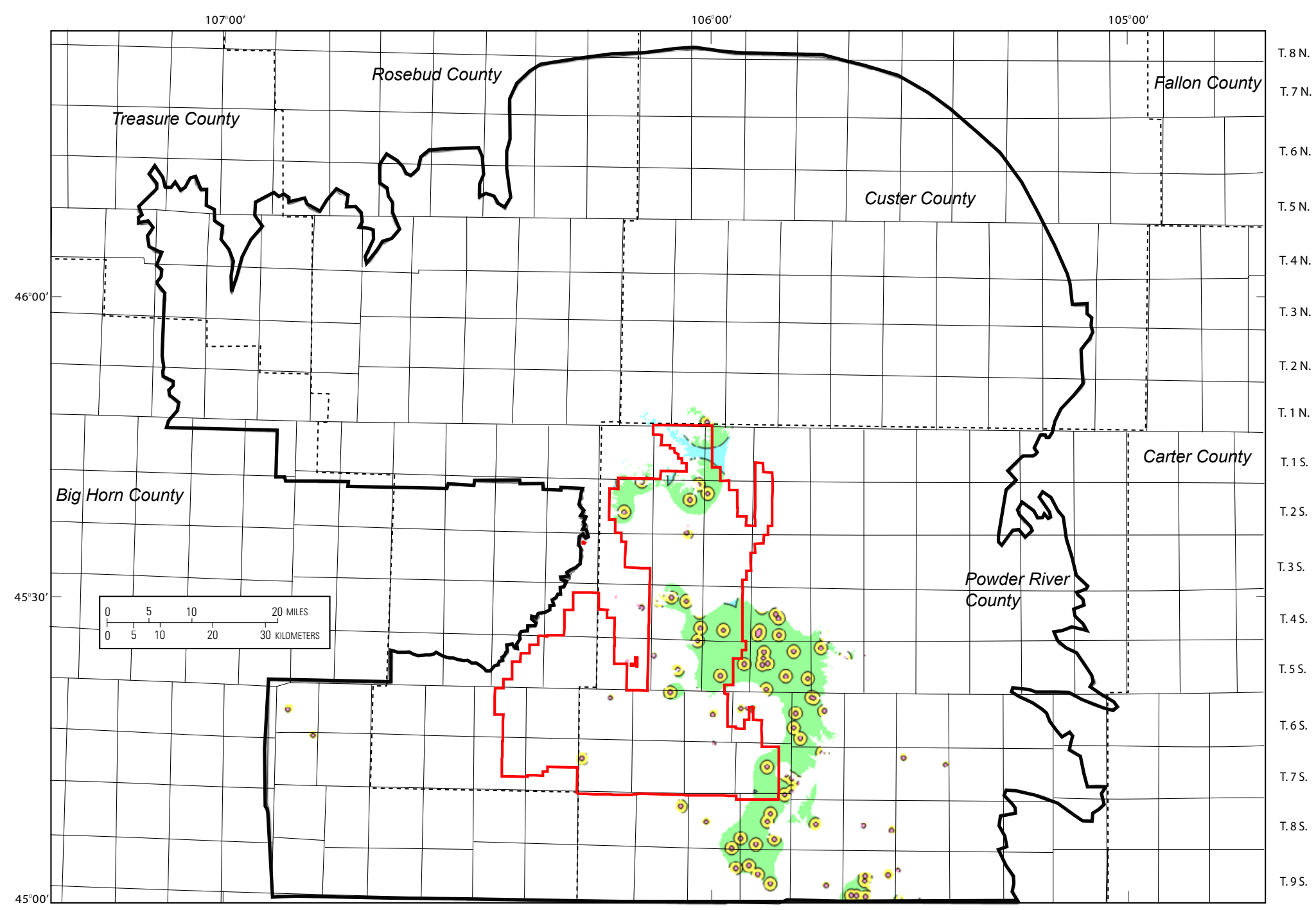

\begin{tabular}{l} 
EXPLANATION \\
\begin{tabular}{|l|l|}
\hline Hypothetical \\
Inferred \\
Indicated \\
Measured
\end{tabular} \\
Montana Powder \\
River Basin assessment \\
area \\
Custer National Forest \\
INDEX MAP \\
\hline Montana \\
Powder River Basin \\
\hline
\end{tabular}

Figure 68. Map showing coal resource reliability categories for the Odell coal bed within the Montana Powder River Basin assessment area. 


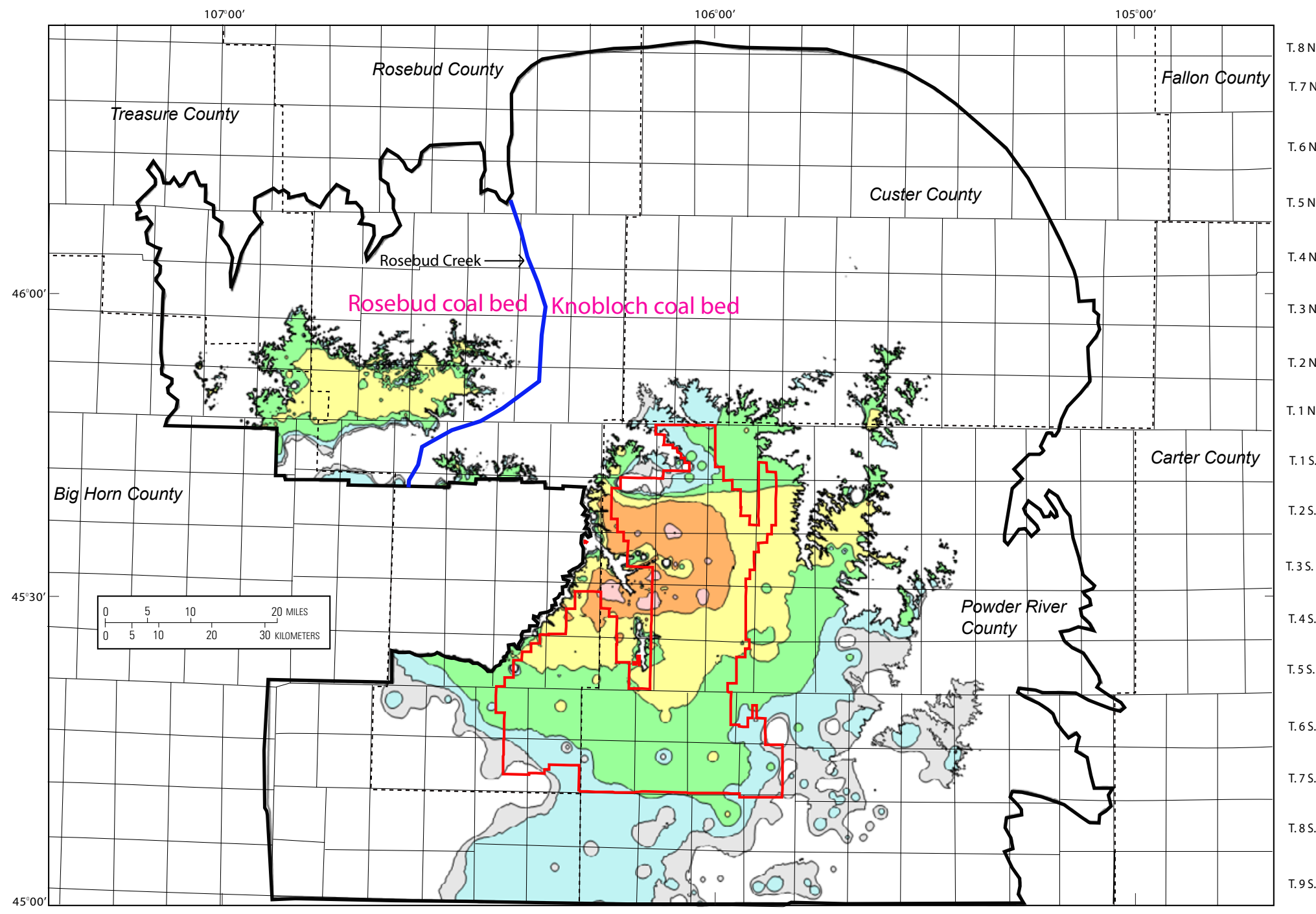

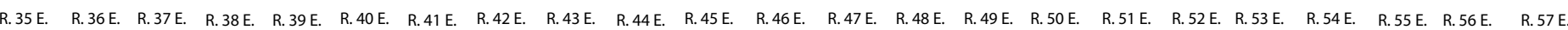

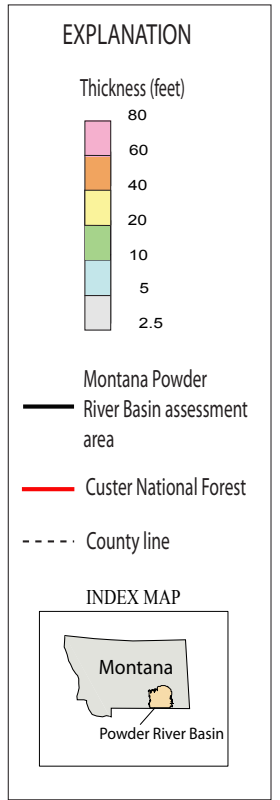

Figure 69. Isopachs showing extent of resources at least 2.5 feet thick in the Rosebud/Knobloch coal beds within the Montana Powder River Basin assessment area. 


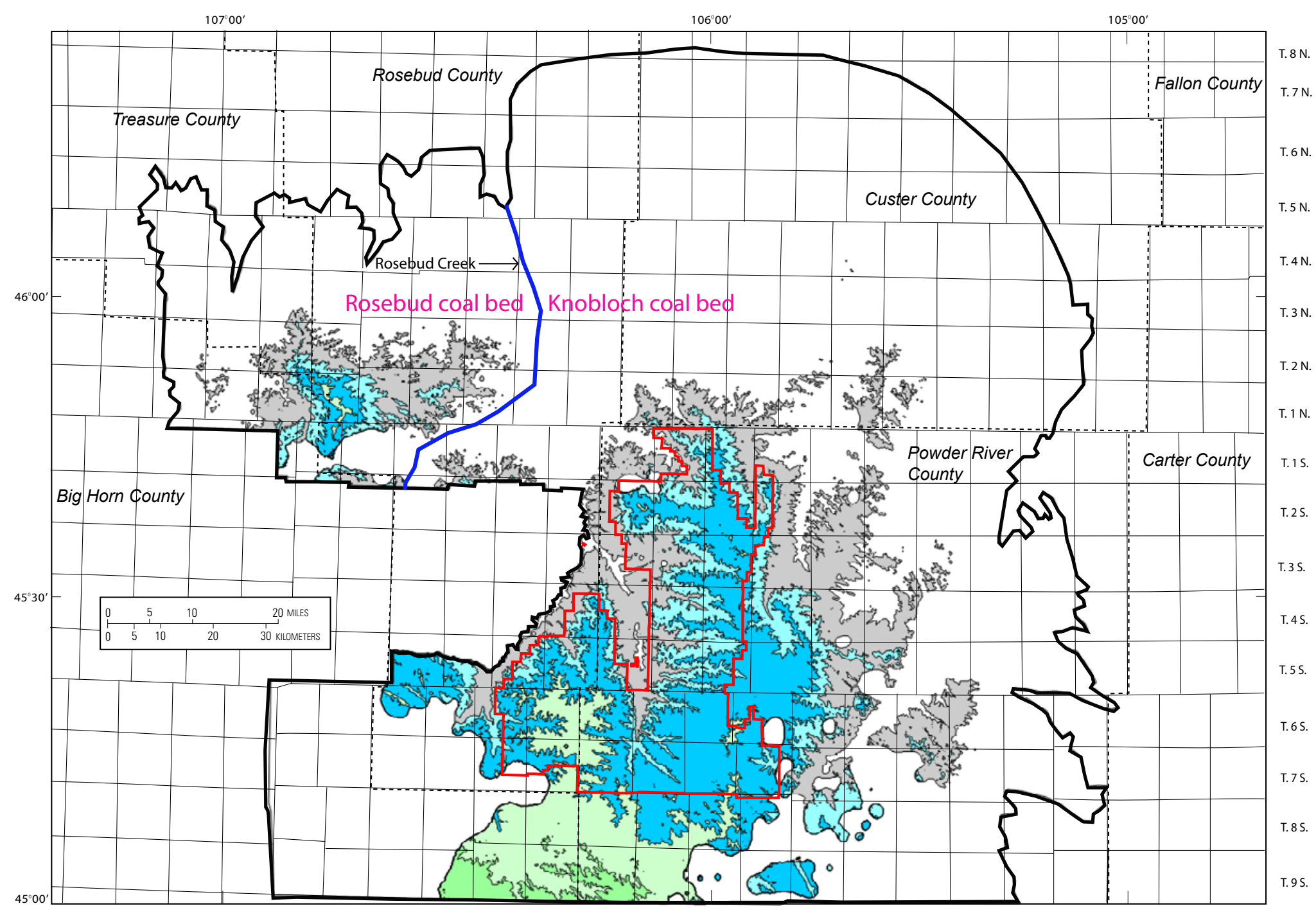

Figure 70. Map showing depth to the top of the Rosebud/Knobloch coal beds within the Montana Powder River Basin assessment area. 


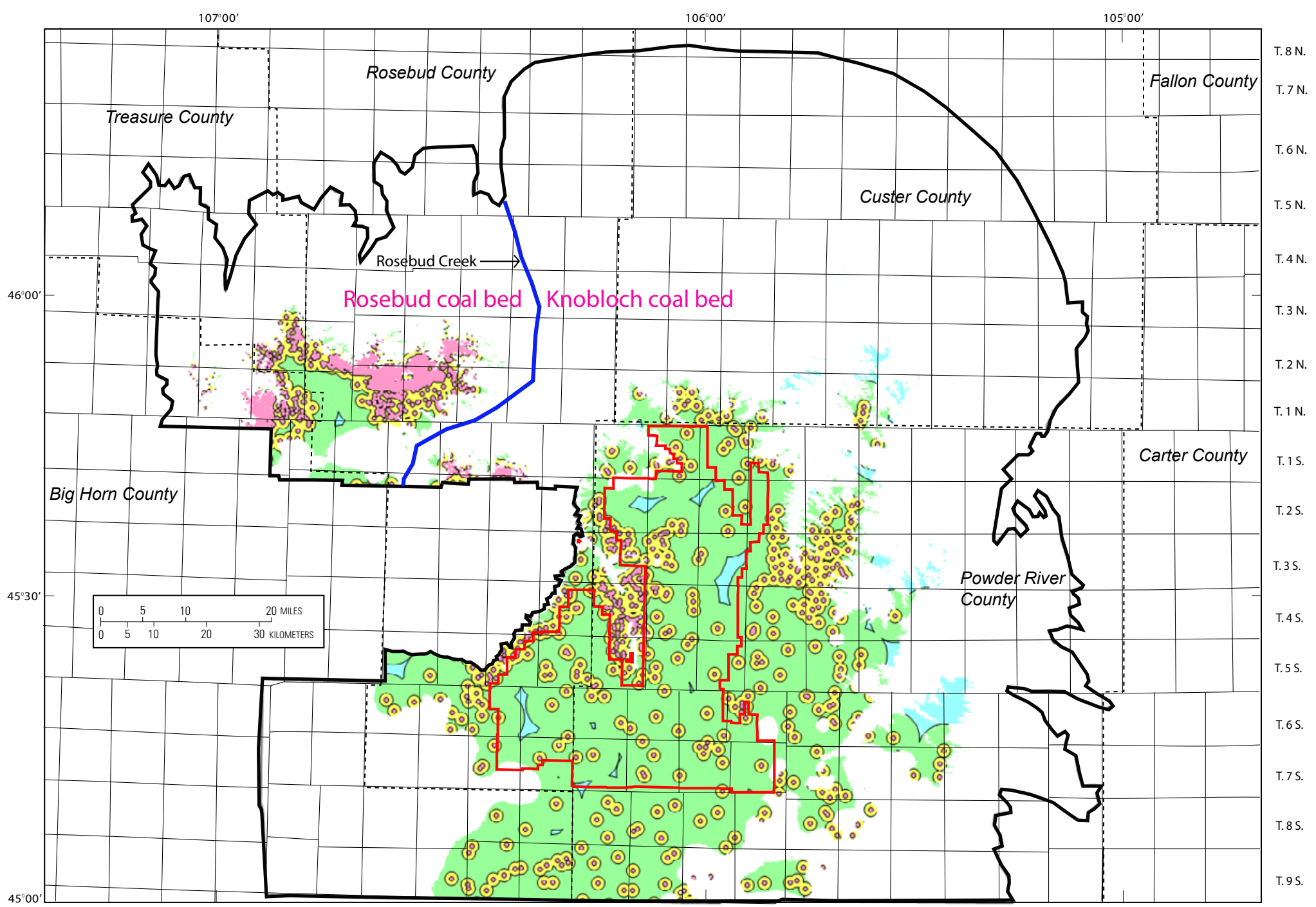

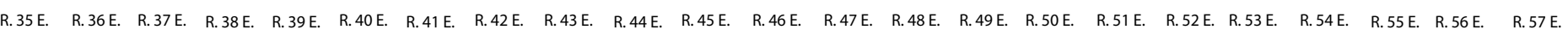

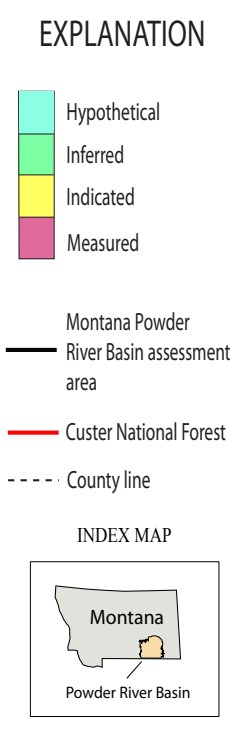

Figure 71. Map showing coal resource reliability categories for the Rosebud/Knobloch coal beds within the Montana Powder River Basin assessment area. 


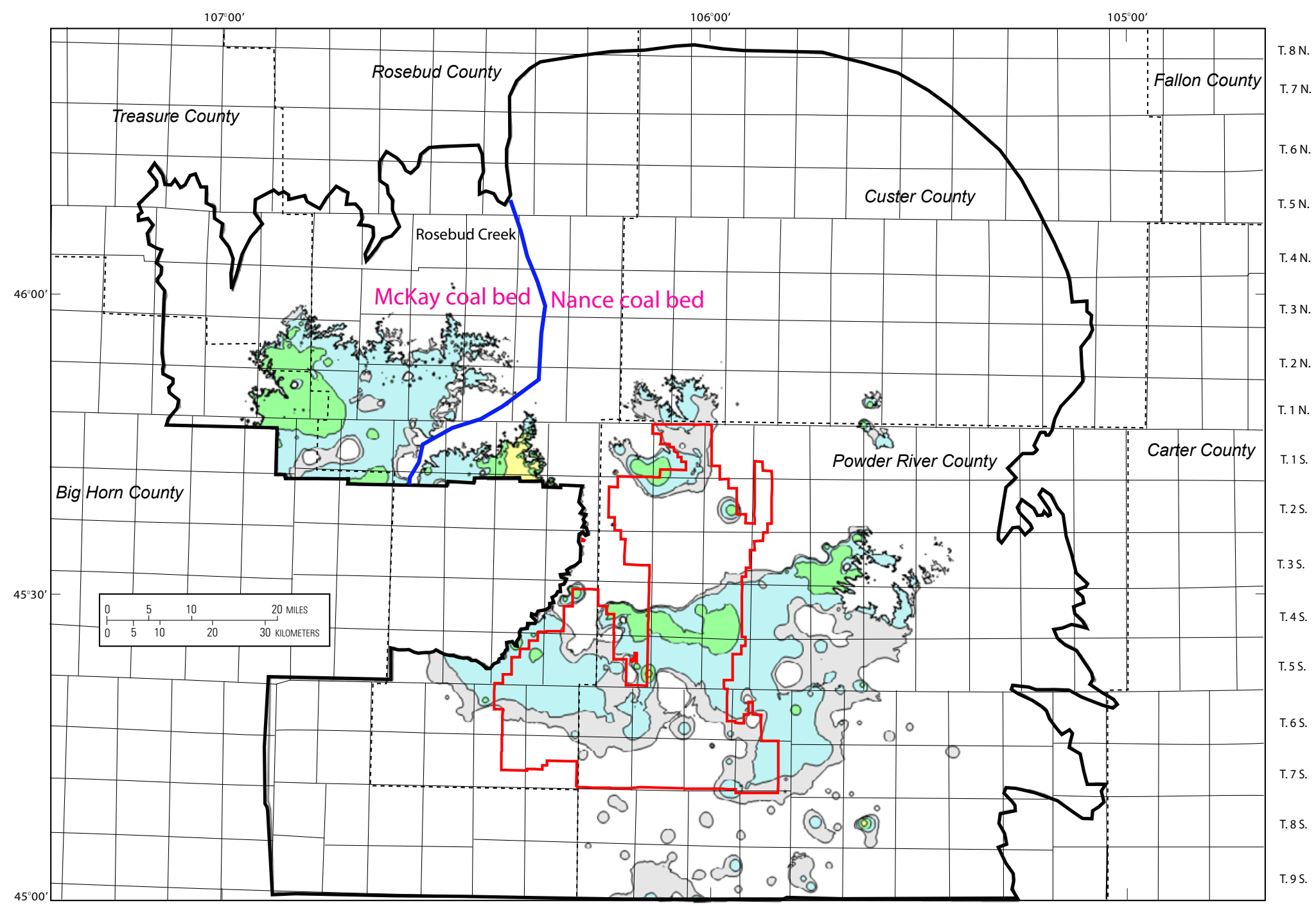

T. $8 \mathrm{~N}$.

T. $6 \mathrm{~N}$.

Figure 72. Isopachs showing extent of resources at least 2.5 feet thick in the McKay/Nance coal beds within the Montana Powder River Basin assessment area. 


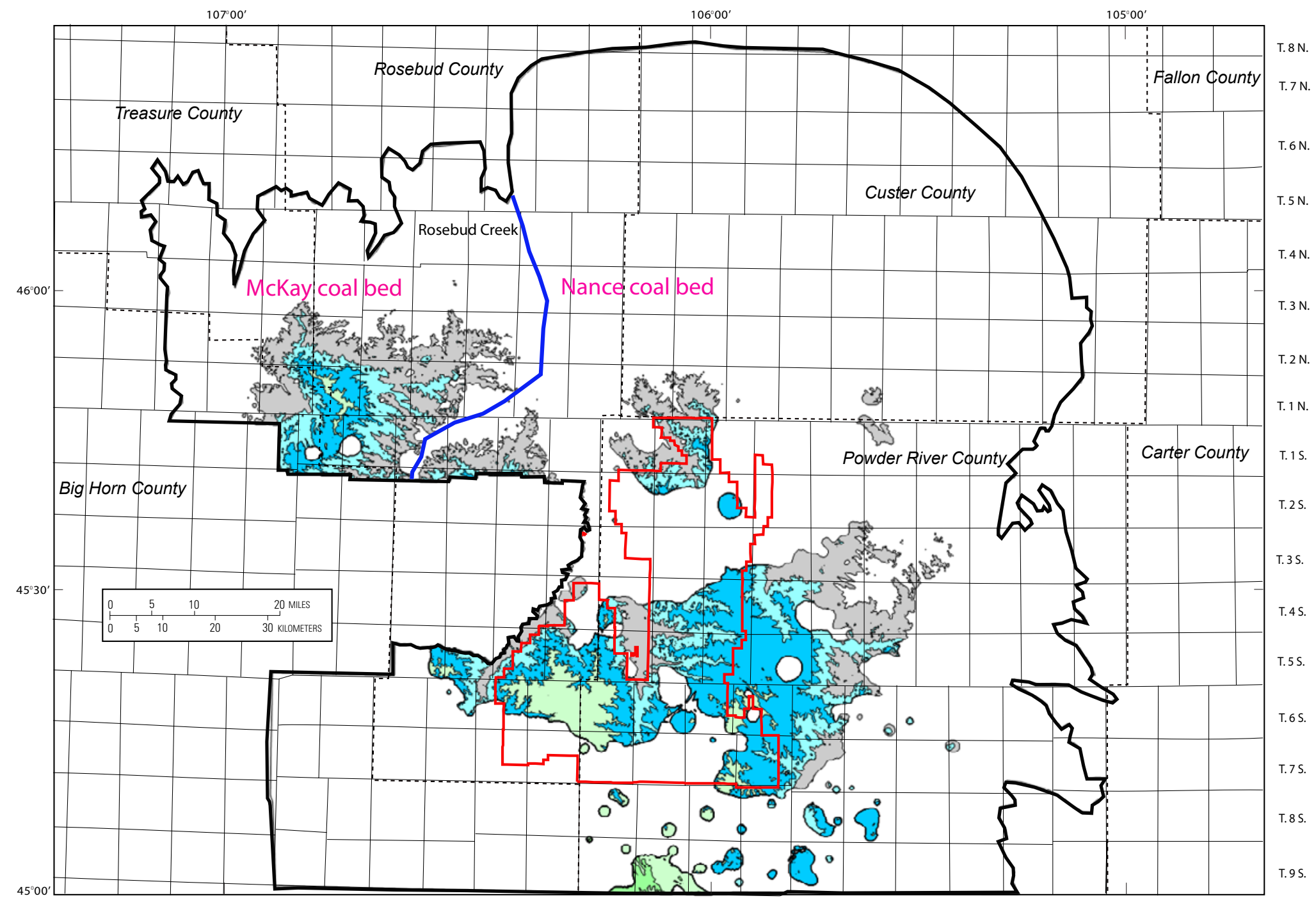

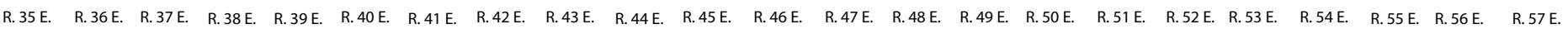

Figure 73. Map showing depth to the top of the McKay/Nance coal beds within the Montana Powder River Basin assessment area. 


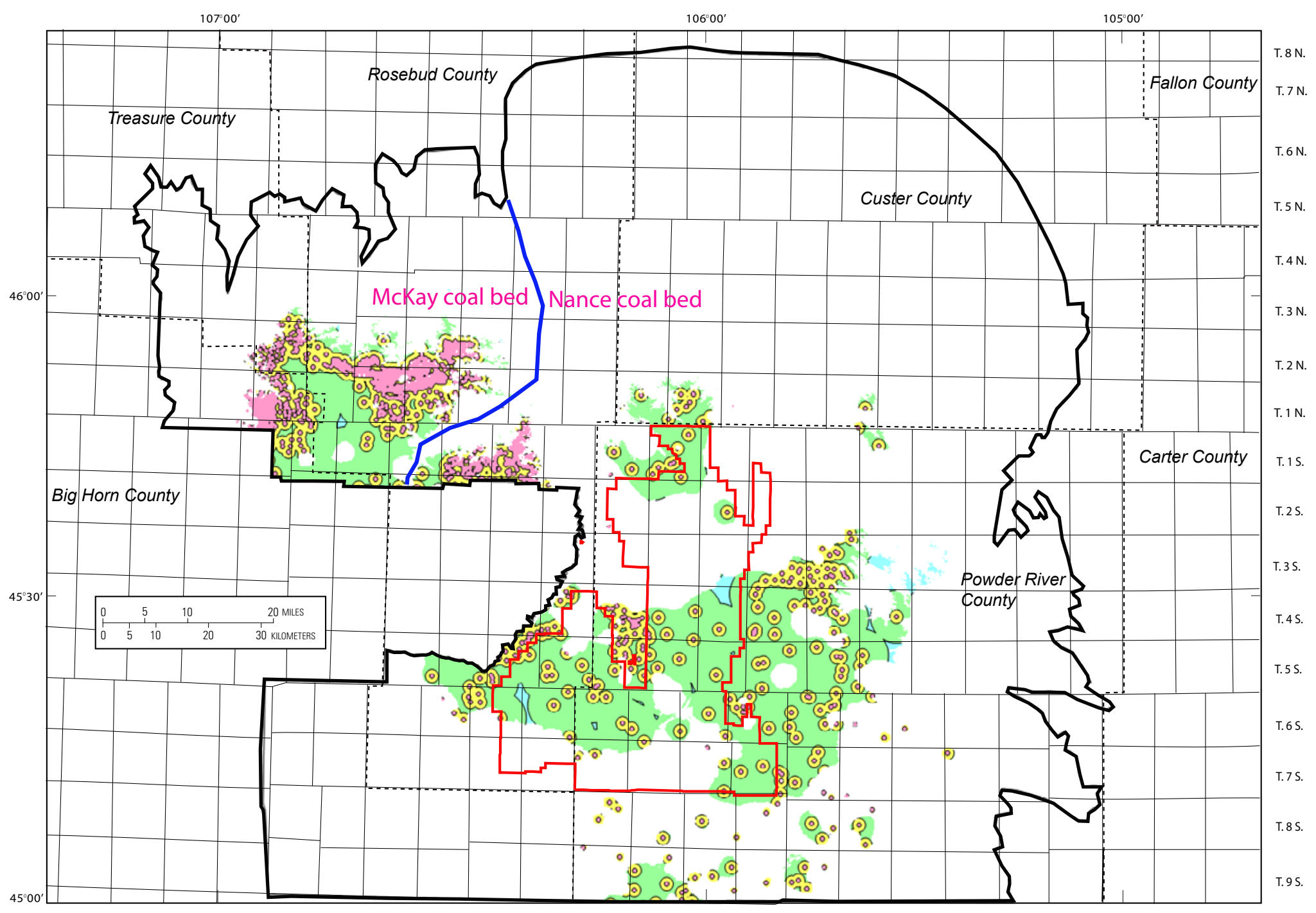

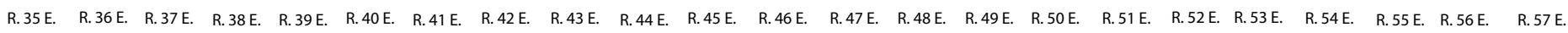

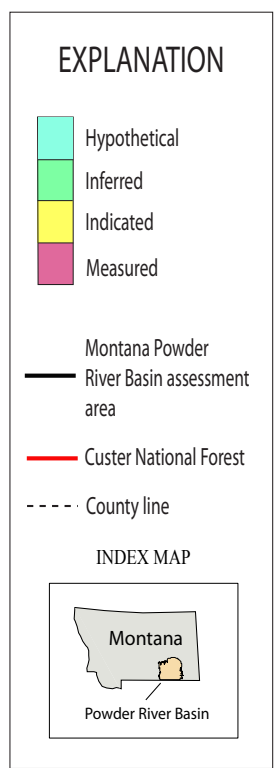

Figure 74. Map showing coal resource reliability categories for the McKay/Nance coal beds within the Montana Powder River Basin assessment area. 


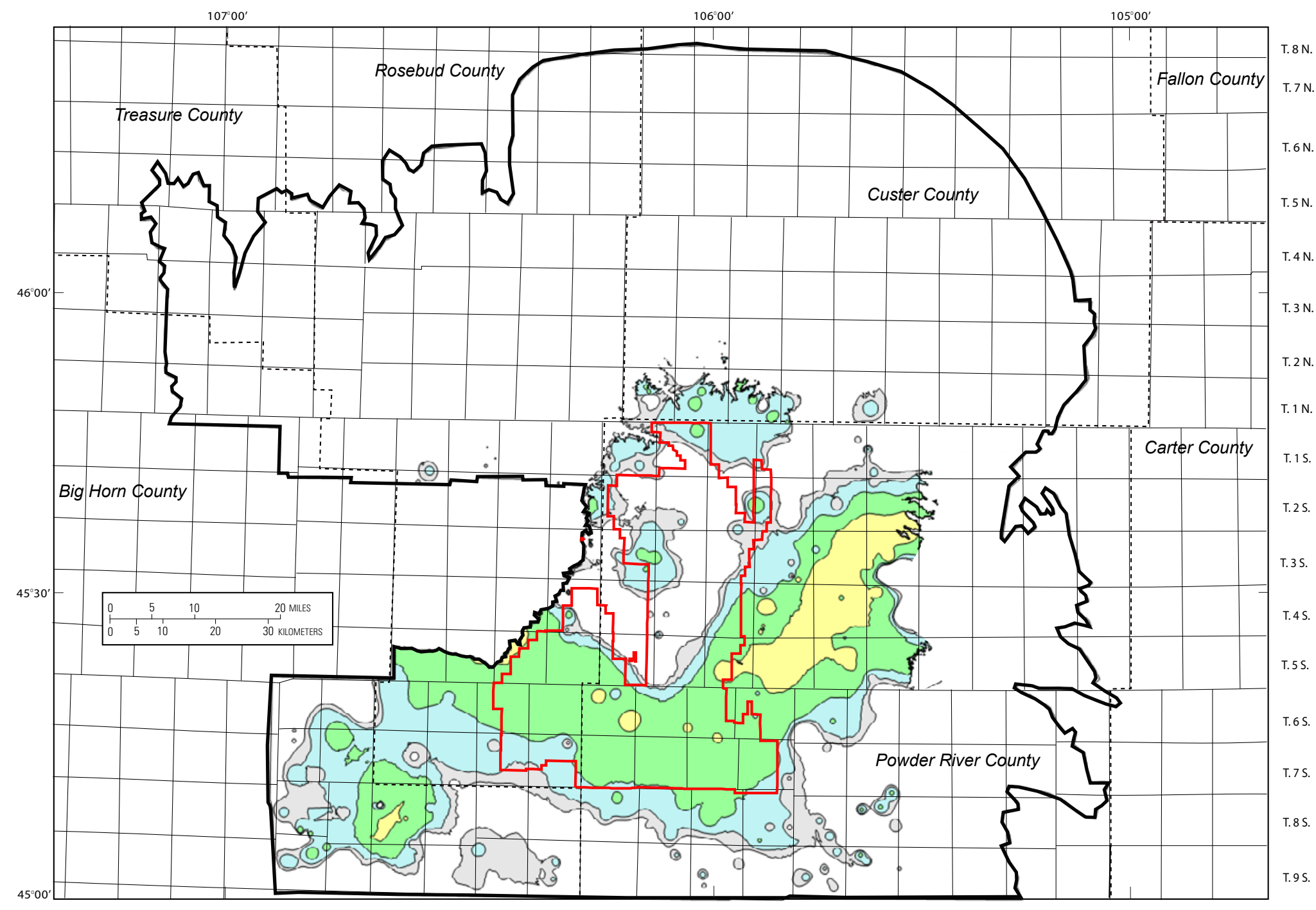

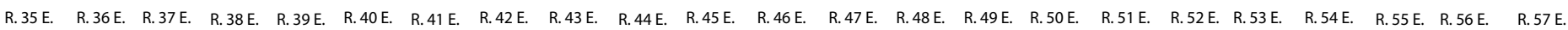

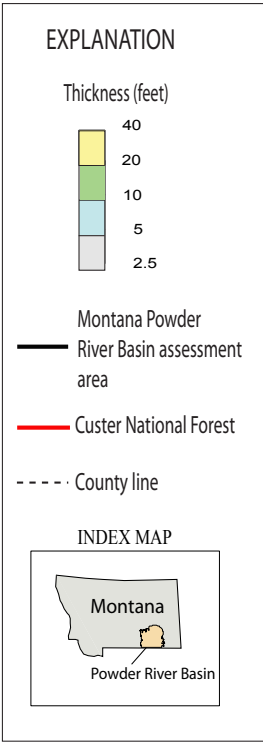

Figure 75. Isopachs showing extent of resources at least 2.5 feet thick in the Flowers-Goodale coal bed within the Montana Powder River Basin assessment area. 


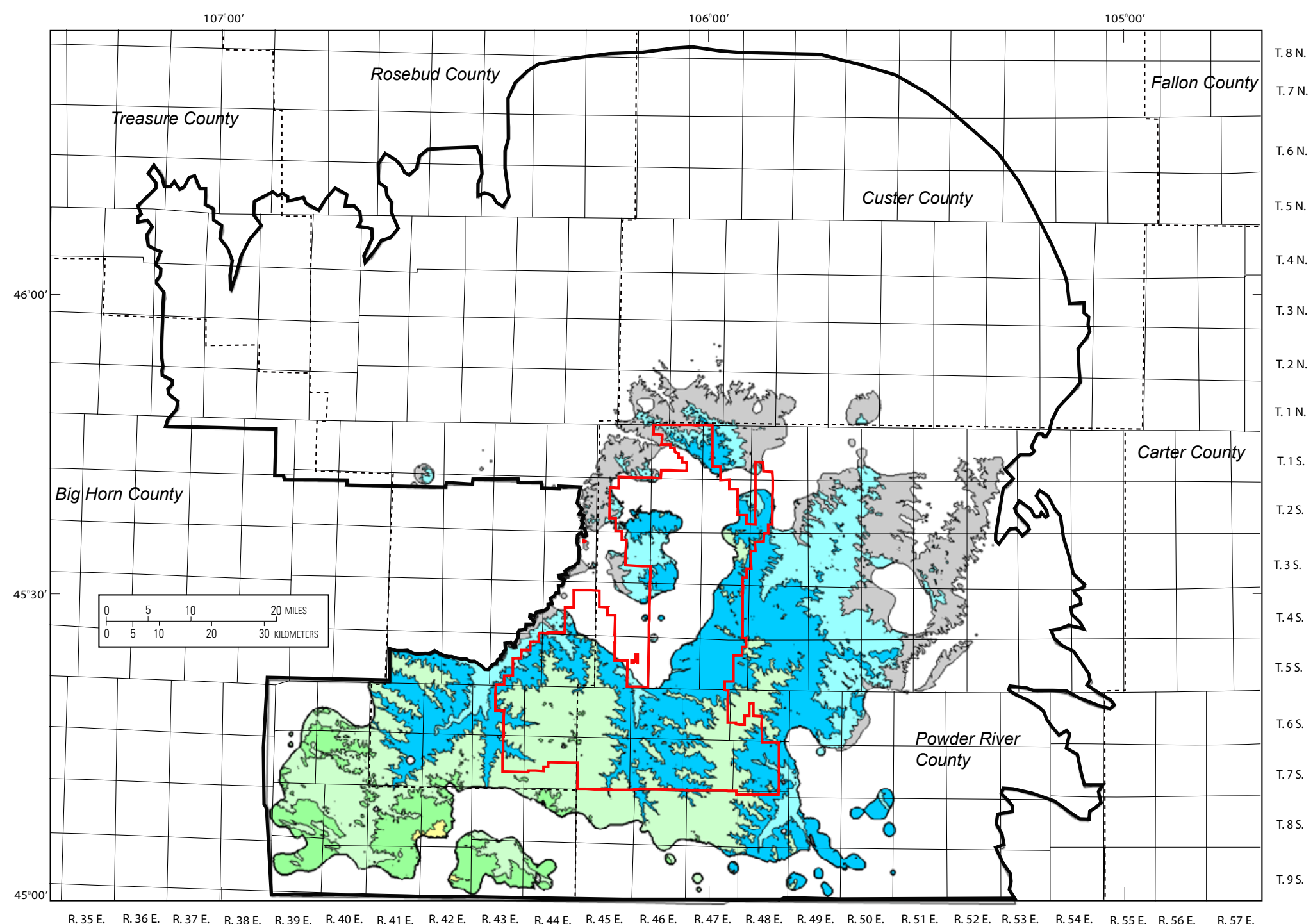

$$
\begin{aligned}
& \text { EXPLANATION }
\end{aligned}
$$

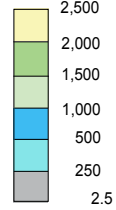

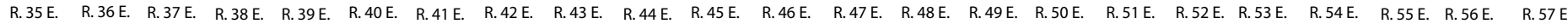

Figure 76. Map showing depth to the top of the Flowers-Goodale coal bed within the Montana Powder River Basin assessment area. 


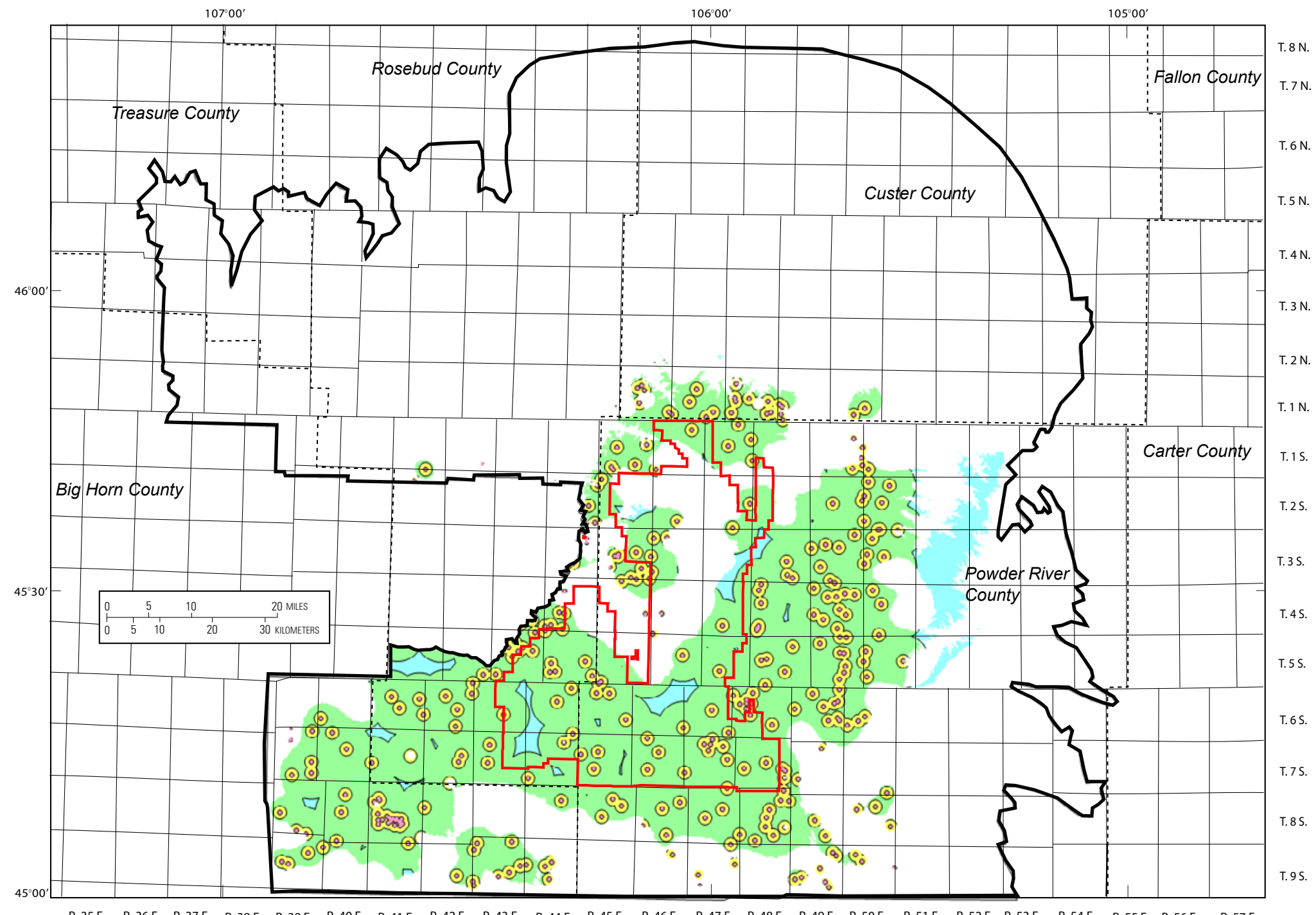

Measured 

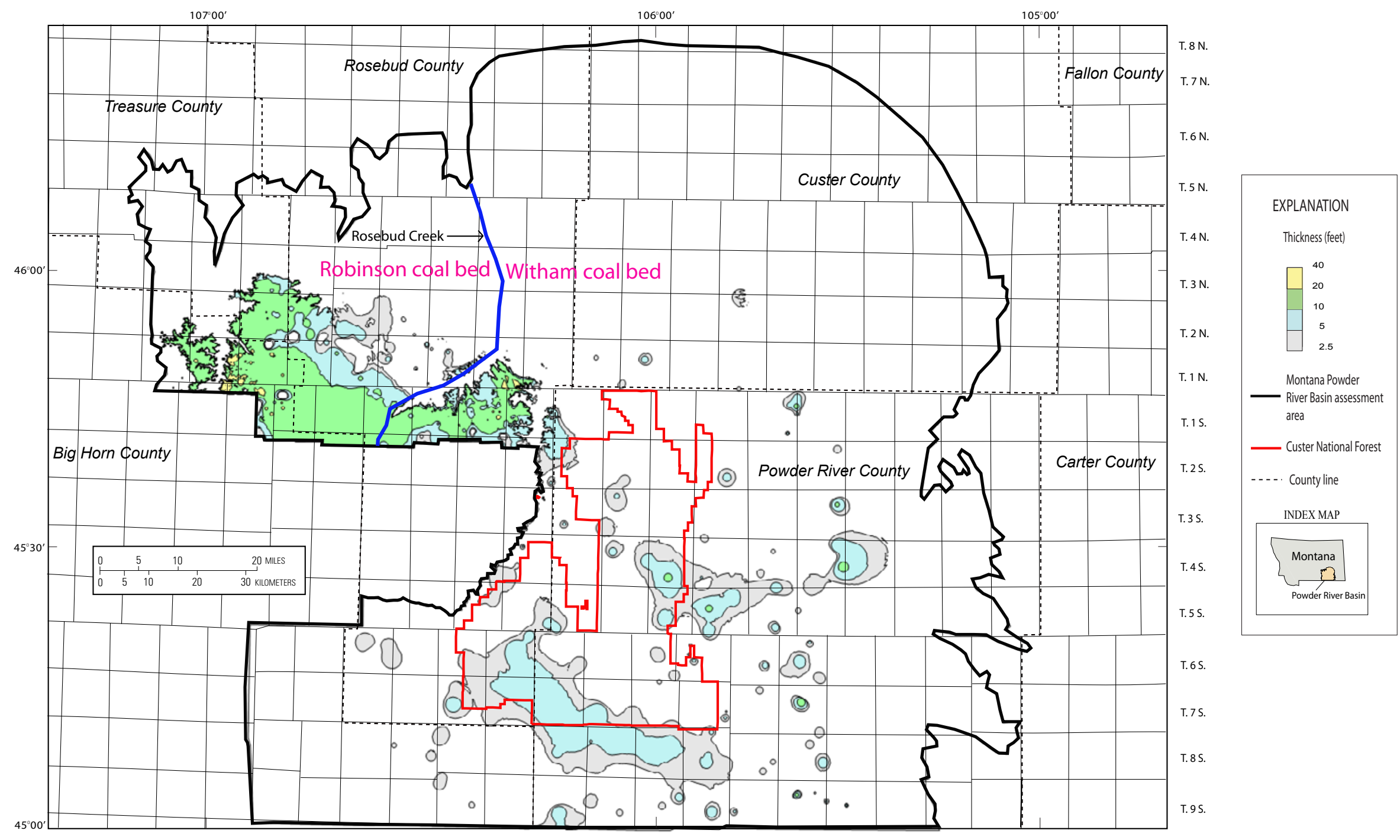

Figure 78. Isopachs showing extent of resources at least 2.5 feet thick in the Robinson/Witham coal beds within the Montana Powder River Basin assessment area. 


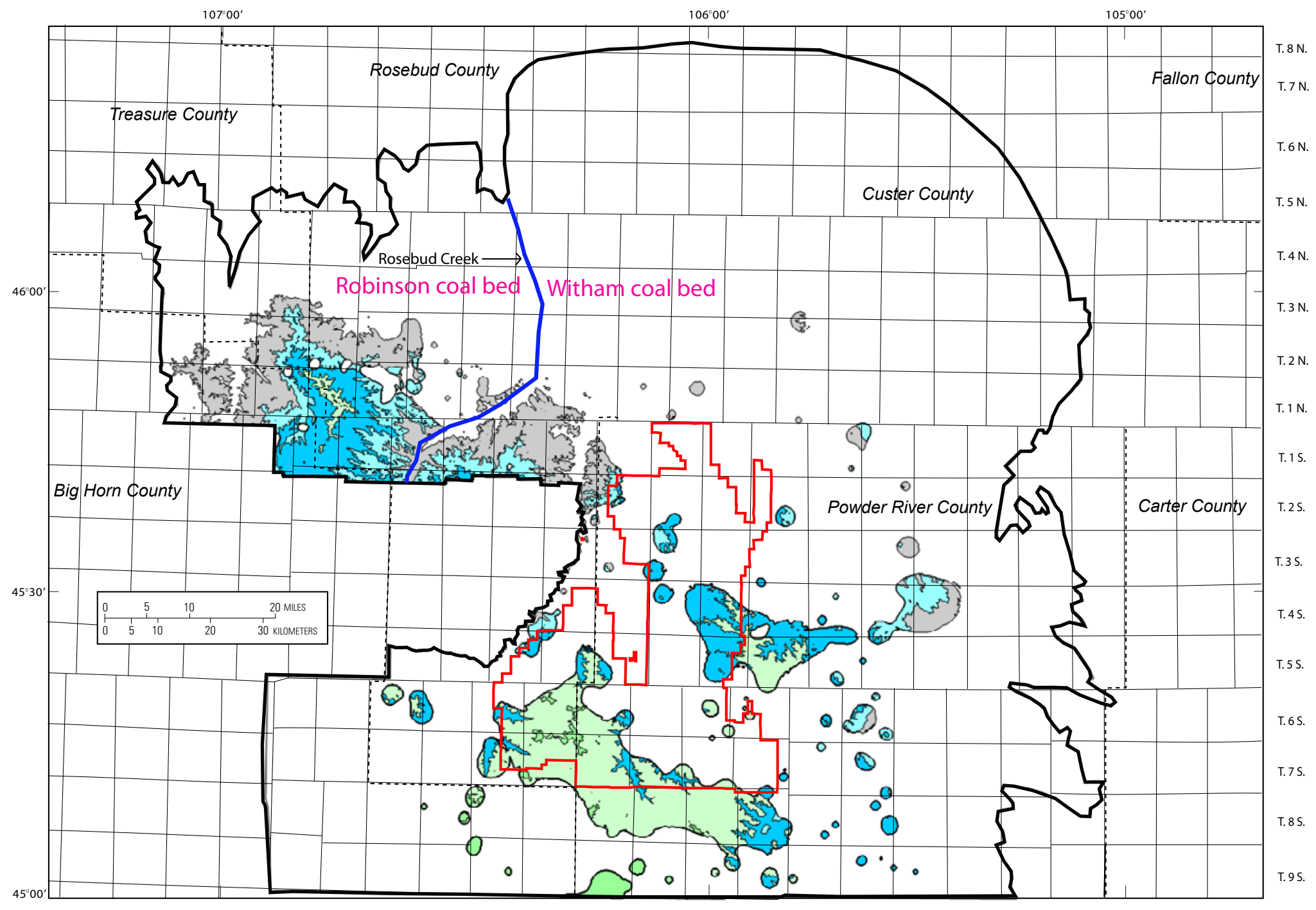

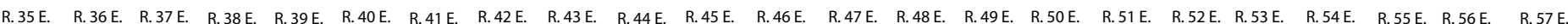

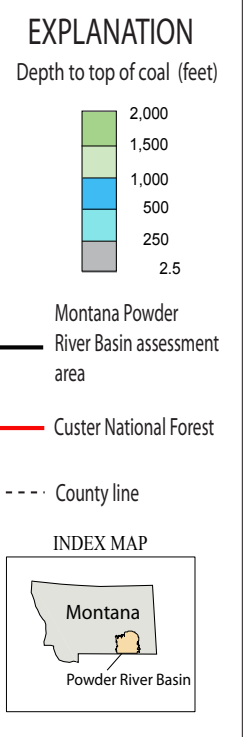

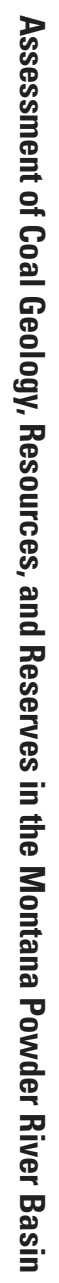

Figure 79. Map showing depth to the top of the Robinson/Witham coal beds within the Montana Powder River Basin assessment area. 


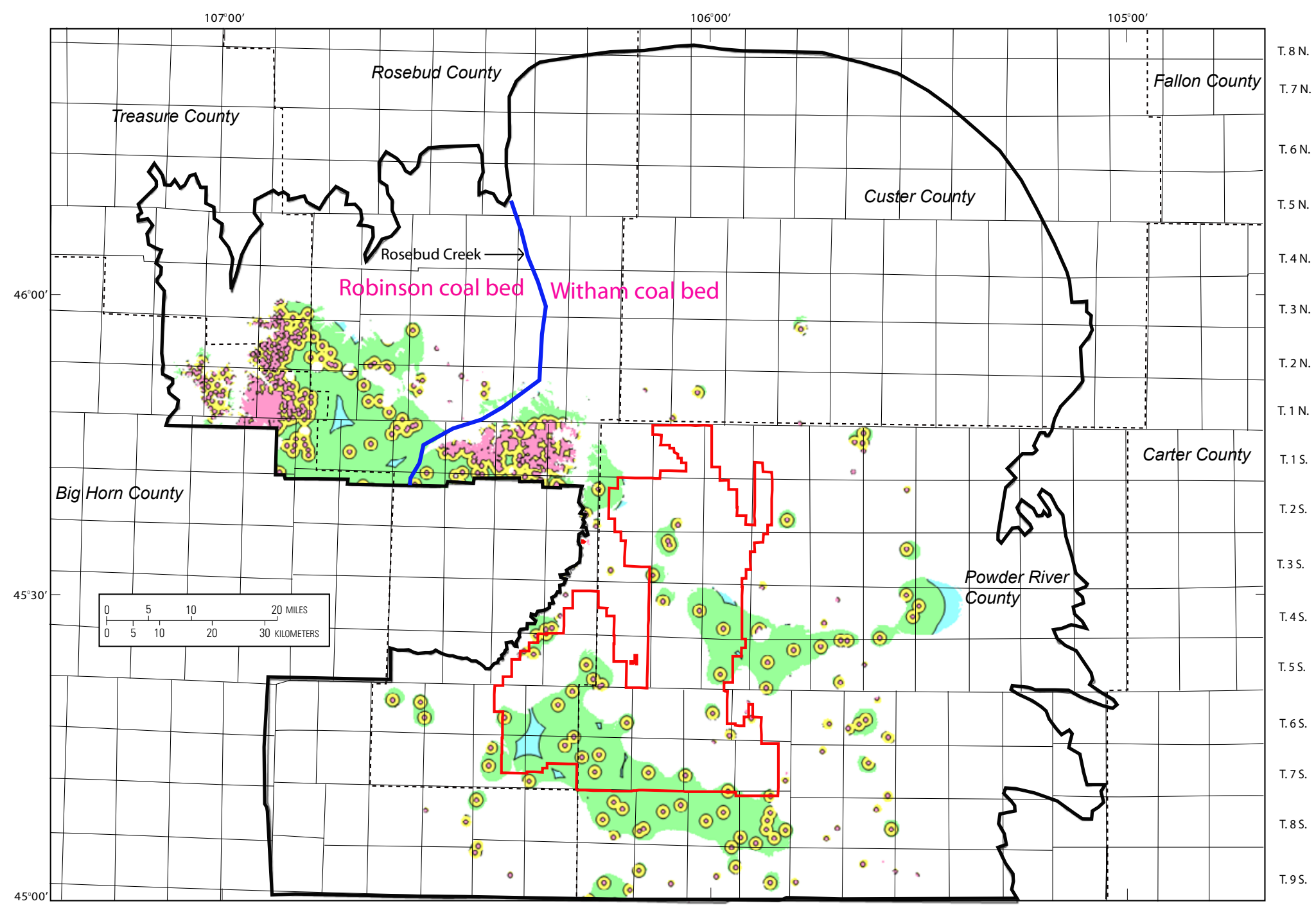

\begin{tabular}{c} 
EXPLANATION \\
$\begin{array}{l}\text { Hypothetical } \\
\text { Inferred } \\
\text { Indicated } \\
\text { Measured }\end{array}$ \\
Montana Powder \\
\hline $\begin{array}{l}\text { River Basin assessment } \\
\text { area }\end{array}$ \\
\hline Custer National Forest \\
-.-. County line \\
INDEX MAP \\
\hline $\begin{array}{l}\text { Montana } \\
\text { Powder River Basin }\end{array}$ \\
\hline
\end{tabular}

Figure 80. Map showing coal resource reliability categories for the Robinson/Witham coal beds within the Montana Powder River Basin assessment area. 


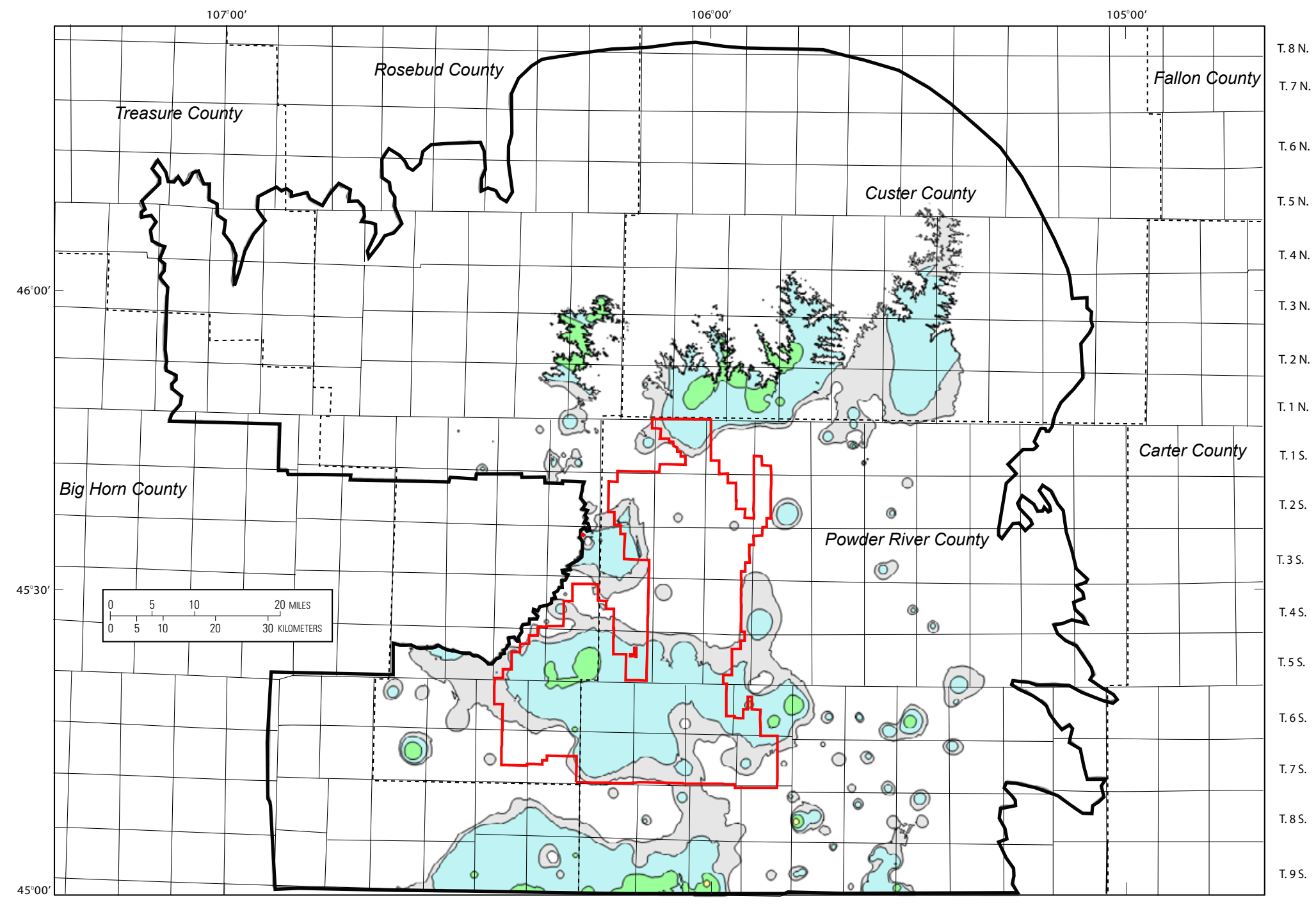

R. 35 E. R. 36 E. R. 37 E. $\quad$ R. 38 E. R. 39 E. R. 40 E. R. 41 E. R. R. 42 E. R. 43 E. R. R. 44 E. R. 45 E. R. R. 46 E. R. 47 E. R. 48 E. R. 49 E. R. 50 E. R. 51 E. R. 52 E. R. 53 E. R. 54 E. R. 55 E. R. 56 E. R. R. 57 E.

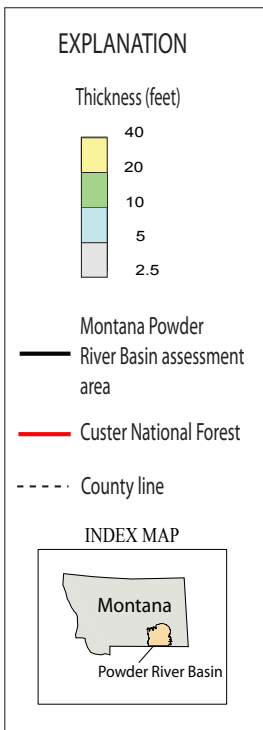

Figure 81. Isopachs showing extent of resources at least 2.5 feet thick in the Roberts/Terret coal beds within the Montana Powder River Basin assessment area. 

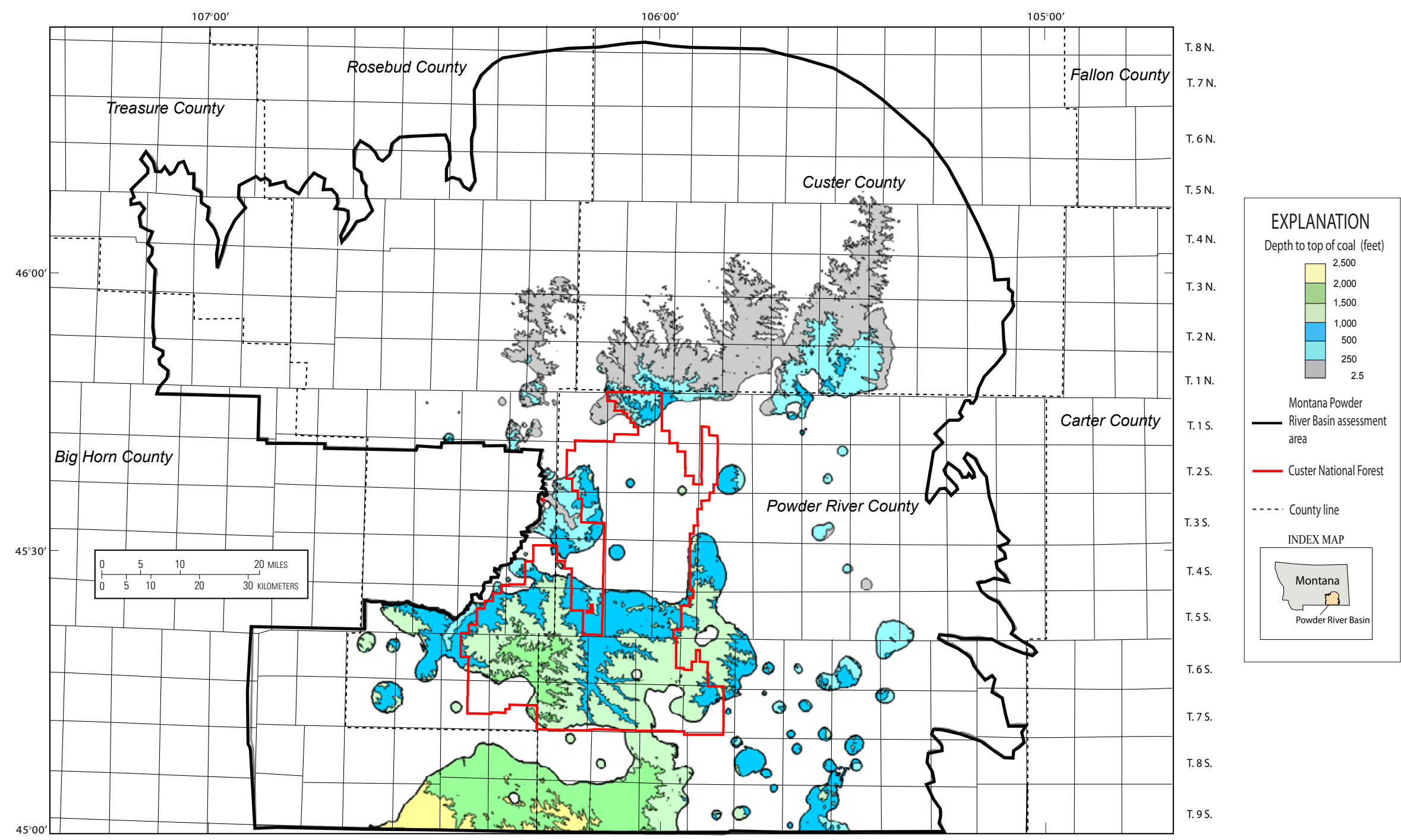

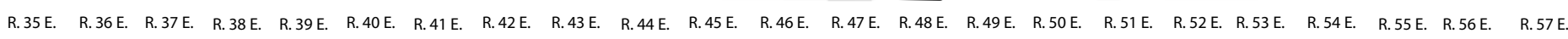

Figure 82. Map showing depth to the top of the Roberts/Terret coal beds within the Montana Powder River Basin assessment area. 


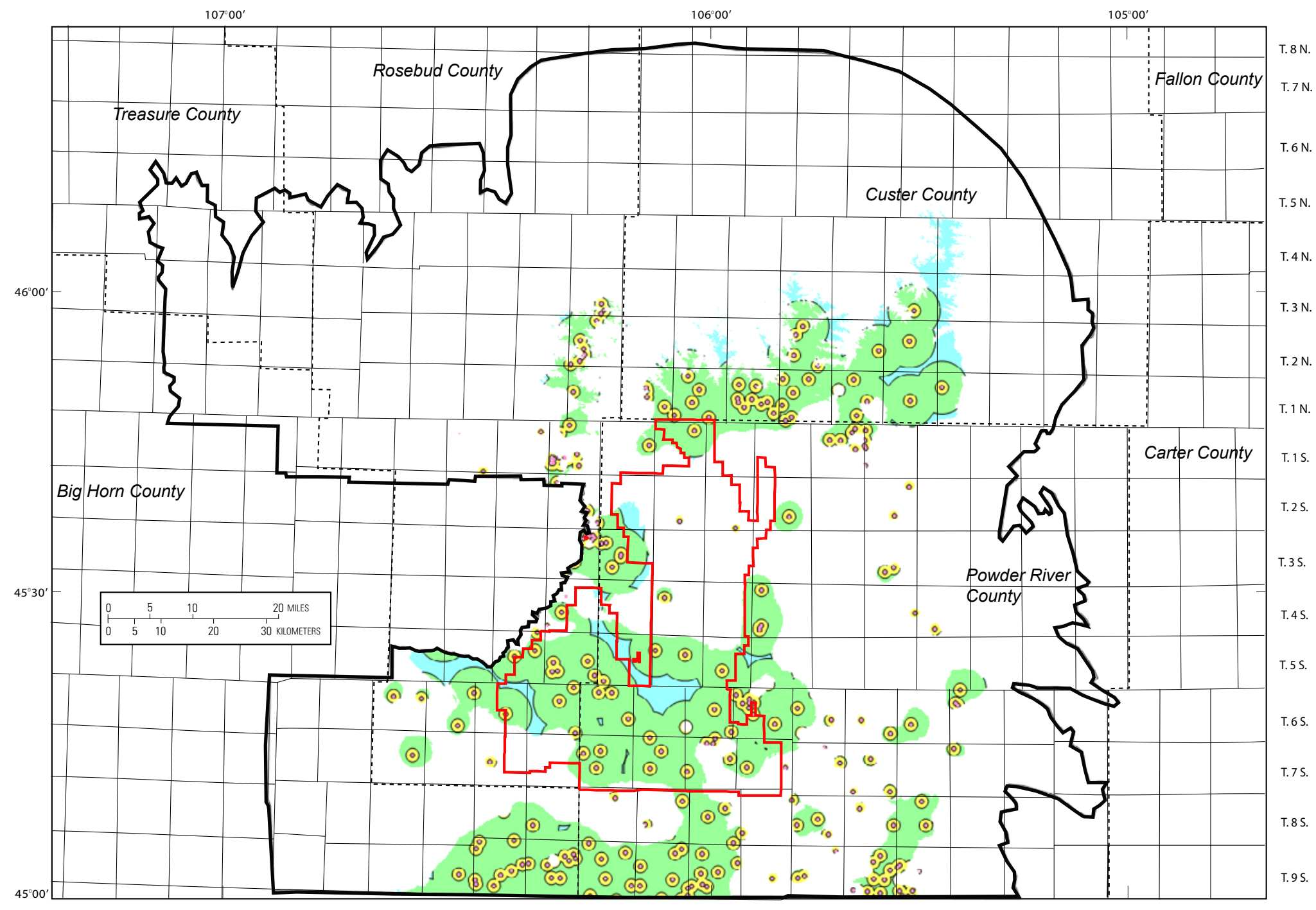

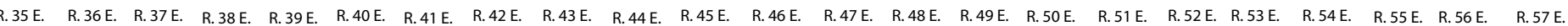

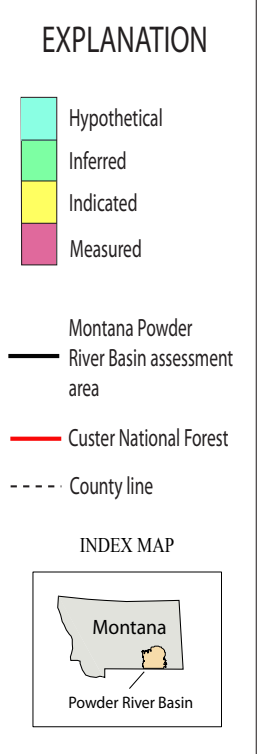

Figure 83. Map showing coal resource reliability categories for the Roberts/Terret coal beds within the Montana Powder River Basin assessment area. 


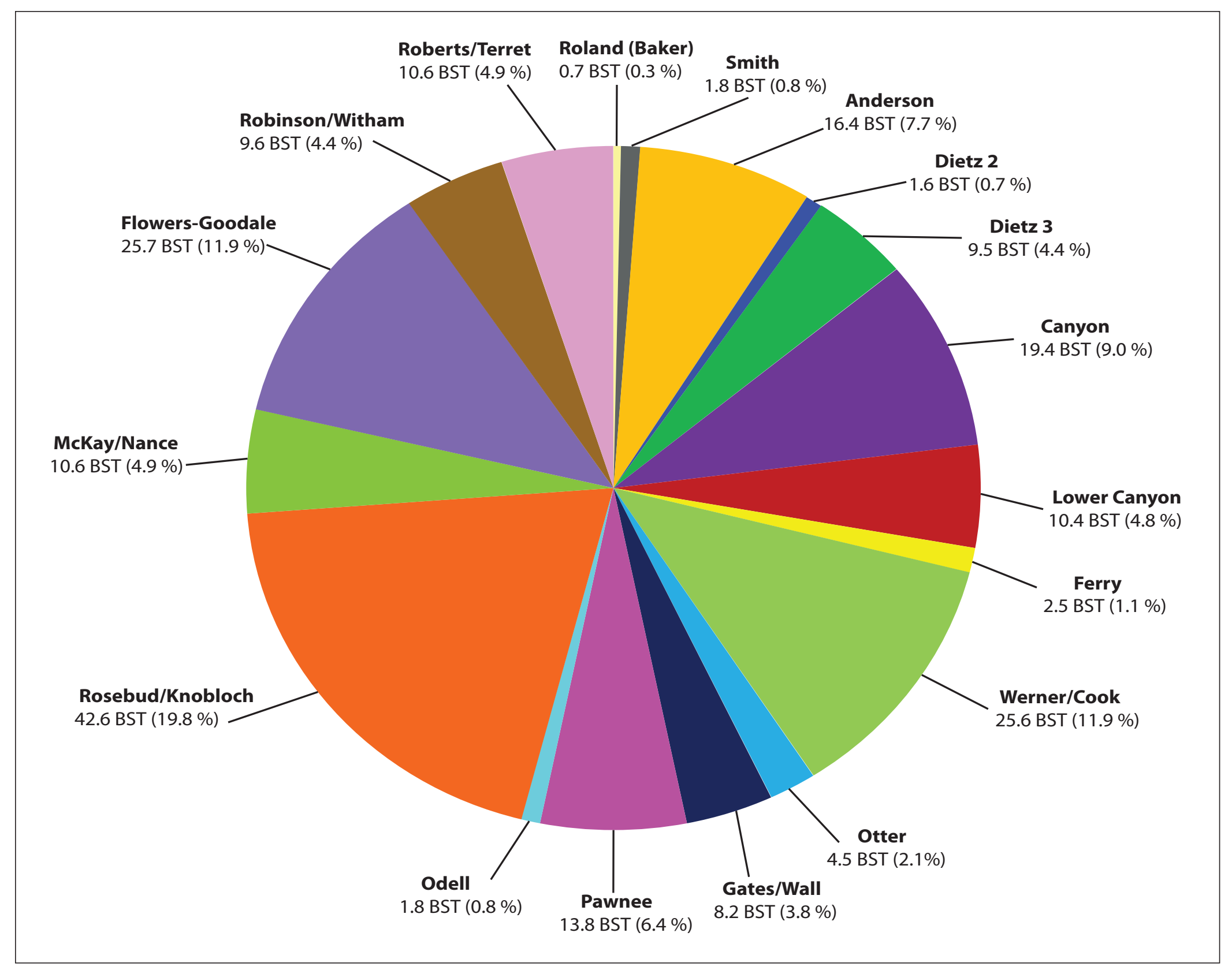

Figure 84. Pie chart of $18 \mathrm{coal}$ beds showing amount and percent of total original coal resources (215 Billion Short Tons (BST)) in individual beds in the Montana Powder River Basin assessment area. 


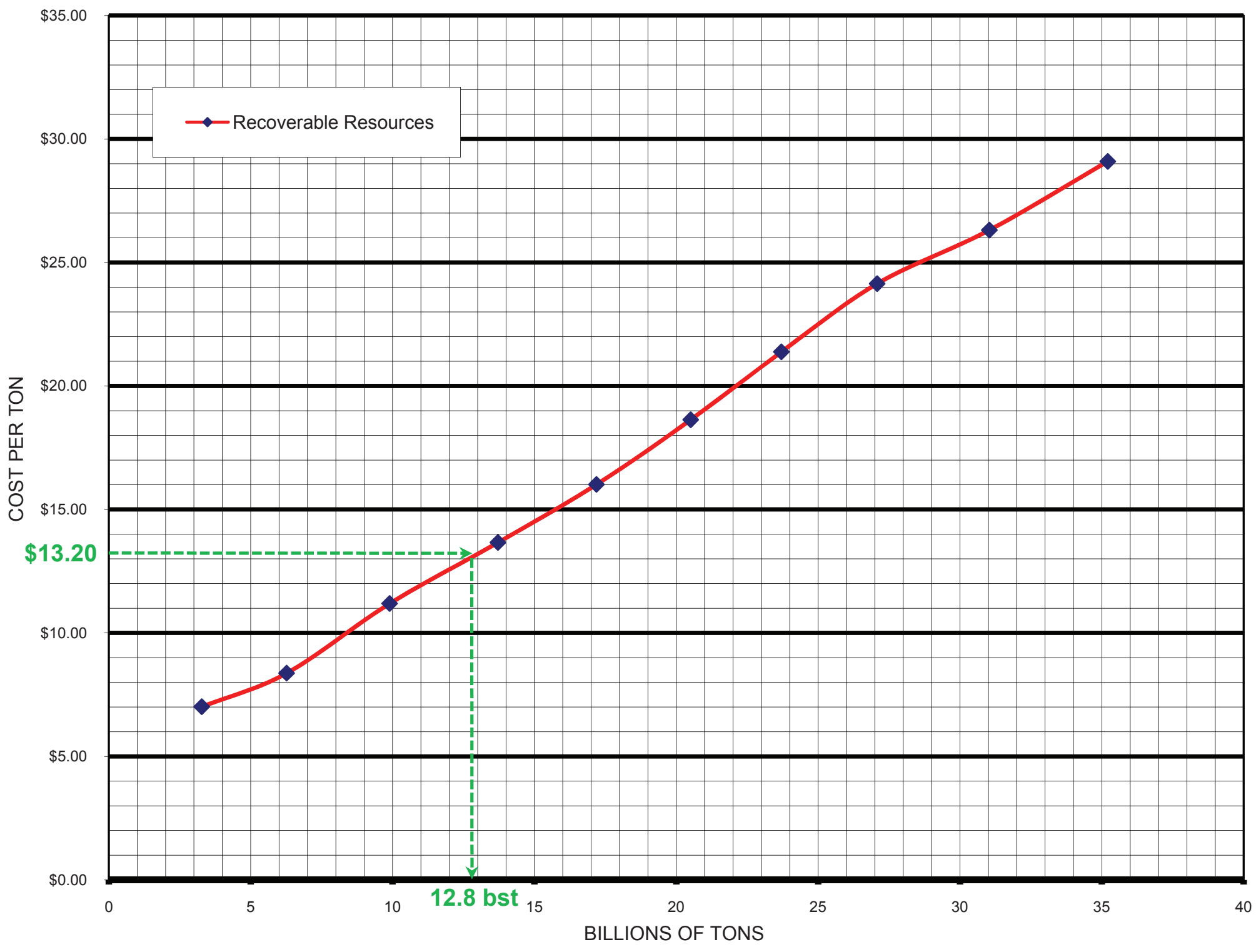

Figure 85. Cost curve showing estimated recoverable resources vs. sales price per ton of coal. Example shows that at the November, 2011 price of $\$ 13.20,12.8$ billion short tons (BST) of coal in assessment area are in the reserve category. 


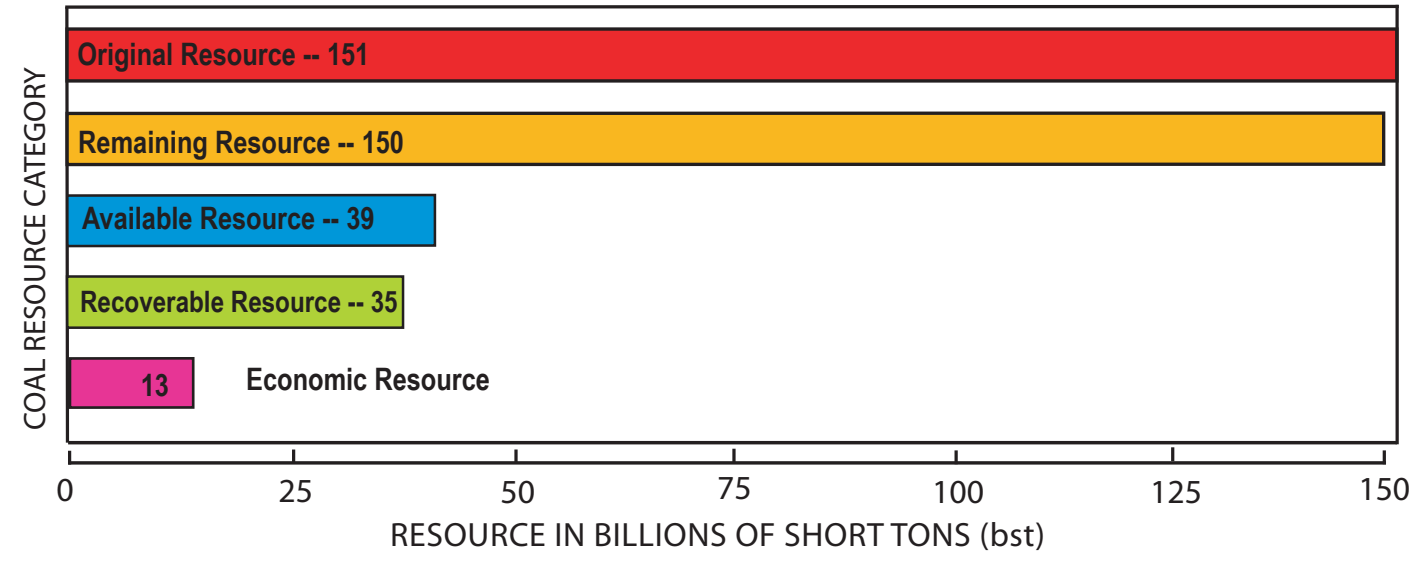

Figure 86. Bar graph showing resources in different resource categories for the ten coal beds included in the reserve evaluation (5.0 feet thick or greater, 10:1 stripping ratio or less) of the Montana Powder River Basin, reported in billions of short tons (at a sales price of $\$ 13.20$ as of November 14, 2011).

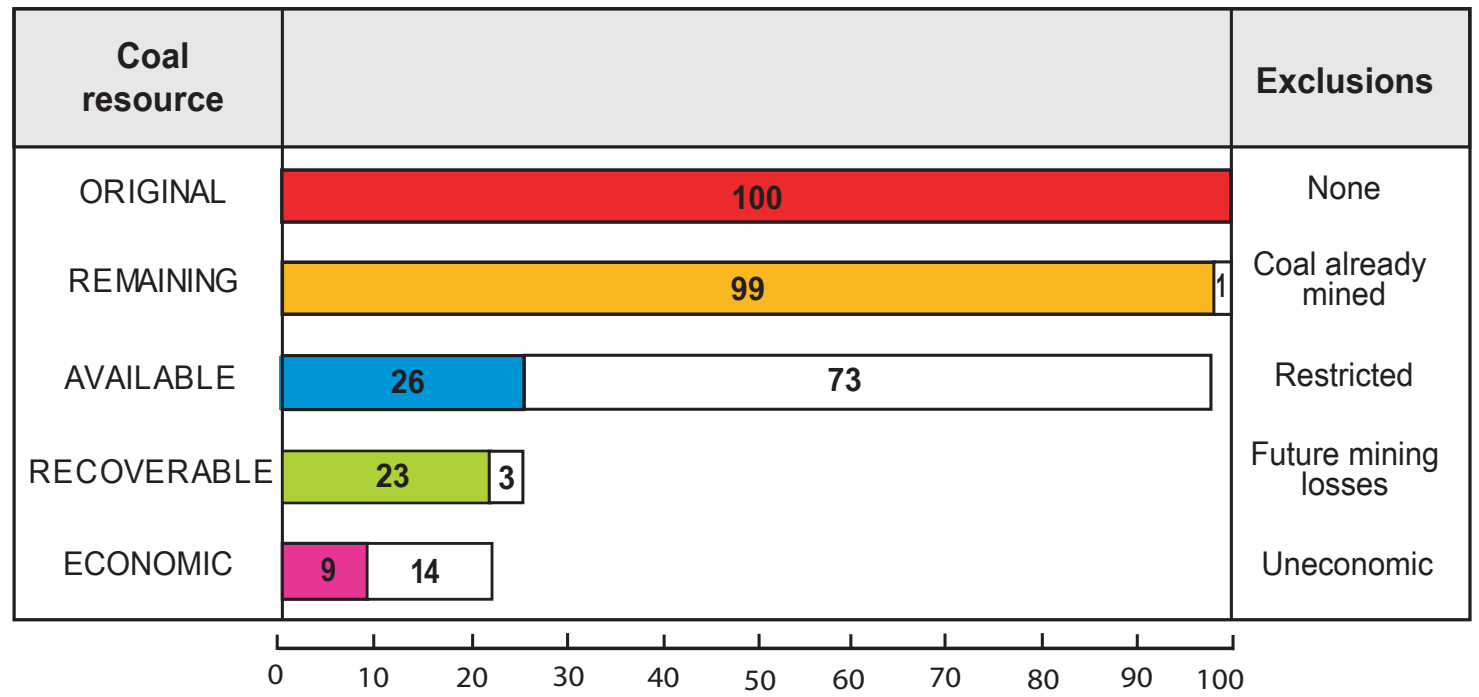

Figure 87. Bar graph showing resources in different resource categories for the ten coal beds included in the reserve evaluation (5.0 feet thick or greater, 10:1 stripping ratio or less) of the Montana Powder River Basin, reported in percentages (at a sales price of $\$ 13.20$ as of November 14, 2011). Percent of remaining resources are shown in colored bars; excluded resources from the previous category are shown in white bars. 


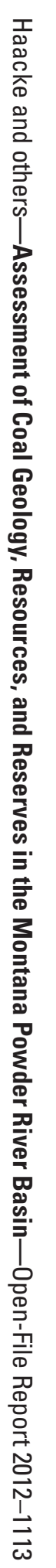

